MICHELLE PINTO DE LIMA

\title{
COMPREENSÃO PSICOSSOCIAL DA VIDA DE TRABALHO PARA PESSOAS COM NANISMO: ENTRE A ESTIGMATIZAÇÃO E O RECONHECIMENTO
}

\author{
Tese apresentada ao Instituto de Psicologia da \\ Universidade de São Paulo, como parte dos requisitos \\ para obtenção do grau de Doutora em Psicologia. \\ Área de Concentração: Psicologia Social \\ Orientador: Prof. Dr. Marcelo Afonso Ribeiro
}

São Paulo 
AUTORIZO A REPRODUÇÃO E DIVULGAÇÃO TOTAL OU PARCIAL DESTE TRABALHO, POR QUALQUER MEIO CONVENCIONAL OU ELETROONICO,

PARA FINS DE ESTUDO E PESQUISA, DESDE QUE CTTADA A FONTE.

Catalogação na publicação

Biblioteca Dante Moreira Leite

Instituto de Psicologia da Universidade de São Paulo

Dados formecidos pelo(a) autor(a)

\section{Pinto de Lima, Michelle}

Compreensão psicossocial da vida de trabalho para pessoas com nanismo: entre a estigmatização e o reconhecimento. / Michelle Pinto de Lima; orientadora Marcelo Afonso Ribeiro. - São Paulo, 2019.

$166 \mathrm{f}$

Tese (Doutorado - Programa de Pós-Graduação em Psicologia Social) - Instituto de Psicologia, Universidade de São Paulo, 2019.

1. Nanismo. 2. Trabalho. 3. Respeito. 4. Estigma. 5. Humilhação. I. Afonso Ribeiro, Marcelo, orient. II. Título. 


\section{FOLHA DE APROVAÇÃO}

Nome: Lima, Michelle Pinto.

Título: Compreensão psicossocial da vida de trabalho para pessoas com nanismo: entre a estigmatização e o reconhecimento.

Tese apresentada ao Instituto de Psicologia da Universidade de São Paulo para obtenção do título de Doutora em Psicologia.

Aprovada em:

Banca Examinadora

Prof. (a) Dr. (a):

Instituição: Julgamento:

Prof. (a) Dr. (a):

Instituição: Julgamento:

Prof. (a) Dr. (a):

Instituição: Julgamento:

Prof. (a) Dr. (a):

Instituição: Julgamento:

Prof. (a) Dr. (a):

Instituição: Julgamento:

Prof. (a) Dr. (a):

Instituição: Julgamento: 


\section{AGRADECIMENTOS}

Muitas pessoas, em muitos momentos, me ajudaram a pensar esta tese. Muitas aulas, cursos e conversas informais suscitaram reflexões e auxiliaram no planejamento destes caminhos. A todas as pessoas que me propiciaram esta oportunidade, gostaria de transmitir meu agradecimento por valorosa colaboração.

Ao meu orientador, Marcelo Ribeiro, pelas contribuições teóricas, escuta ativa e respeito às minhas escolhas de pesquisa. Obrigada por me receber, quase sempre em pânico em razão da complexidade desta temática e refletir comigo sobre as possibilidades deste trajeto.

Ao Instituto de Educação, Ciência e Tecnologia do Piauí, por me conceder a possibilidade do afastamento para esta qualificação.

Aos professores do Instituto de Psicologia da Universidade de São Paulo, pelas muitas experiências teóricas transformadoras a que tive acesso. A docência tem aqui exemplos de posturas intelectuais honestas que ensejam transformação social.

Aos amigos que fiz durante este percurso de doutoramento, sobretudo Julia Malvezzi e Carlos Eduardo Mendes, que muito contribuíram para tornar mais alegres estes anos na cidade de São Paulo e por quem tenho imensa admiração.

Aos amigos que fiz em minhas andanças pelo país, e que, mesmo distantes fisicamente, foram referência e segurança, força e leveza, nestes tempos tão turbulentos que atravessamos.

Ao meu filho, que sempre respeitou minhas decisões sobre ir e vir, sobre onde ficar, ficando sempre comigo. À minha mãe e à minha tia Milagre, agradeço pelo incentivo e o entendimento das minhas escolhas e distâncias inevitáveis.

Àqueles com quem partilho amizade há décadas e que, na medida do seu tempo e do meu, conseguimos partilhar momentos felizes de apoio e afeto que resiste ao tempo e aos deslocamentos. 
Às pessoas com nanismo que participaram desta pesquisa, dedicando seu tempo à recordação de assuntos, muitas vezes íntimos e nem sempre agradáveis. Aos que não participaram diretamente desta pesquisa, mas que muito contribuíram para que ela se tornasse possível. Os convites para participação nas confraternizações das associações de pessoas com nanismo e as conversas individuais a respeito das diversas questões que envolvem a vida com nanismo foram fundamentais para as reflexões aqui presentes. À Kênia, presidente da Associação de Pessoas com Nanismo do Rio de Janeiro, muito obrigada. 
"E anão nada mais é que um ser gigante por dentro, alguém que esqueceu de crescer por fora, que inverteu o sentido e o significado de vir e ir embora, de crer e de ser, de crescer."

(Giovanni Venturini) 


\section{RESUMO}

Lima, M. P. (2019). Compreensão psicossocial da vida de trabalho para pessoas com nanismo: entre a estigmatização e o reconhecimento (Tese de Doutorado). Instituto de Psicologia, Universidade de São Paulo, São Paulo.

A complexidade psicossocial de nanismo difere de outras condições incluídas sob a rubrica de incapacidade física devido a construções culturais socialmente existentes em torno de sua identidade. A construção simbólica a respeito do seu corpo é central nesta experiência da diferença, cuja anormalidade se inscreve em um regime de visibilidade mais próximo do exótico, o que atrai um mercado de trabalho voltado para o entretenimento. Em razão do uso do estigma como força de trabalho, este estudo tem como objetivo compreender a vida de trabalho para pessoas com nanismo através de uma análise psicossocial. Para isto, buscou-se identificar as consequências da estigmatização na vida social, como ela se reproduz na esfera do trabalho e compreender as possibilidades de reconhecimento no trabalho. Foi realizada uma pesquisa exploratória e descritiva, com a participação de sete pessoas com nanismo. Com cada uma delas foi realizada uma entrevista semiestruturada e as narrativas foram tratadas com análise de conteúdo, que geraram cinco temas: família, trajetória educacional, relações sociais, vida de trabalho e reconhecimento. Em torno deles, quando necessário, foram extraídos subtemas para delimitar e aprofundar a discussão. Os resultados indicaram que na vida social as pessoas com nanismo passam por experiências de humilhação e desrespeito em razão das associações feitas ao estereótipo construído a seu respeito. Na esfera do trabalho, este estereótipo é usado como base para recrutamento em atividades ligadas ao cômico e ao entretenimento. A Lei de Cotas teve impacto significativo na criação de oportunidades em empregos convencionais, o que permitiu mobilidade ocupacional para entrevistados que passaram anos em trabalhos estereotipados. Nos ambientes corporativos, ser reconhecido em pé de igualdade a outros funcionários, e ao mesmo tempo em sua diferença, com adequação para acessibilidade, por exemplo, foram mencionados como fatores de reconhecimento. No mercado informal de trabalho, a autonomia para negociar as condições e o tipo de trabalho artístico esteve entre as possibilidades de reconhecimento. Com estes resultados, pretende-se preencher lacunas até então abertas sobre estudos relacionados a trabalho de pessoas com nanismo.

Palavras-chave: Acondroplasia. Mercado de trabalho. Estigma. Humilhação. Reconhecimento. 


\begin{abstract}
Lima, M. P. (2019). Psychosocial understanding of working life for people with dwarfism: between stigmatization and recognition (Tese de Doutorado). Instituto de Psicologia, Universidade de São Paulo, São Paulo.

The psychosocial complexity of dwarfism differs from other conditions included under the rubric of physical incapacity due to socially constructed cultural constructs around its identity. The symbolic construction of his/her body is central to this experience of difference, whose abnormality is inscribed in a regime of visibility closer to the exotic, which attracts a labor market focused on entertainment. Because of the use of stigma as a work force, this study aims to understand working life for people with dwarfism through a psychosocial analysis. For this, we sought to identify the consequences of stigmatization in social life, how it reproduces in the sphere of work and understand the possibilities of recognition at work. An exploratory and descriptive research was carried out, with the participation of seven people with dwarfism. With each of them, a semi-structured interview was conducted, and the narratives were treated with content analysis, which generated five themes: family, educational trajectory, social relations, working life and recognition. Around them, when necessary, sub-themes were extracted to delimit and deepen the discussion. The results indicated that in social life people with dwarfism go through experiences of humiliation and disrespect because of the associations made to the stereotype constructed about them. In the sphere of work, this stereotype is used as a basis for recruitment into comedic and entertaining activities. The Quota Law had a significant impact on the creation of opportunities in conventional jobs, which allowed occupational mobility for interviewees who spent years in stereotyped jobs. In corporate environments, being recognized on an equal footing with other employees, and at the same time in their difference, with suitability for accessibility, for example, were mentioned as recognition factors. In the informal labor market, the autonomy to negotiate the conditions and the type of artistic work was among the possibilities of recognition. With these results, it is intended to fill gaps until then open on studies related to the work of people with dwarfism.
\end{abstract}

Keywords: Achondroplasia. Labor market. Stigma. Humiliation. Recognition. 


\section{LISTA DE TABELAS}

Tabela 1 - Quadro de Análise Temática 


\section{SUMÁRIO}

1 INTRODUÇÃO ........................................................................................................ 18

1.1 Nanismo: uma condição social de desrespeito $\quad$.......................................................................... 19

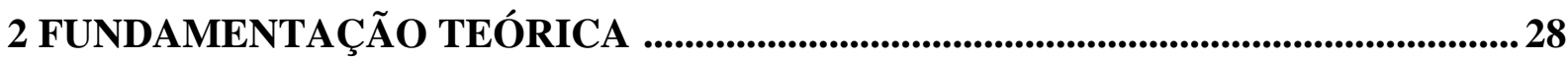

2.1 Nanismo: da estigmatização à humilhação social ............................................................ 29

2.2 O reconhecimento em Axel Honneth ........................................................................ 43

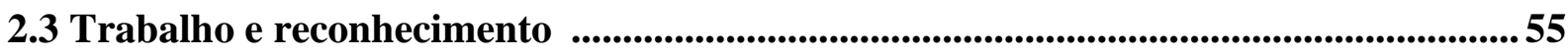

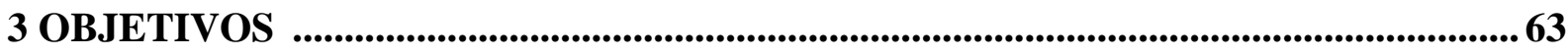

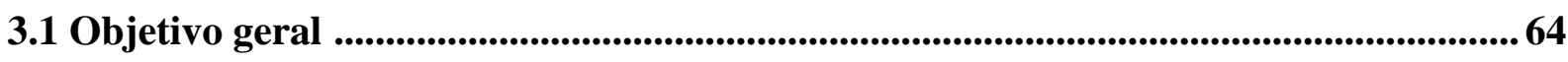

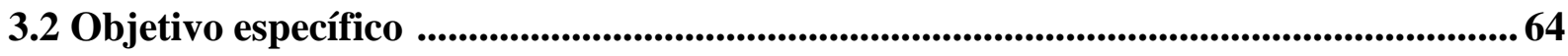

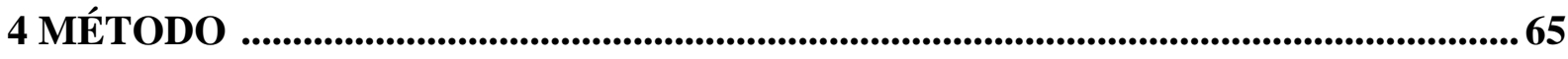

4.1 Caracterização da pesquisa

4.2 Procedimentos ............................................................................................................................ 67

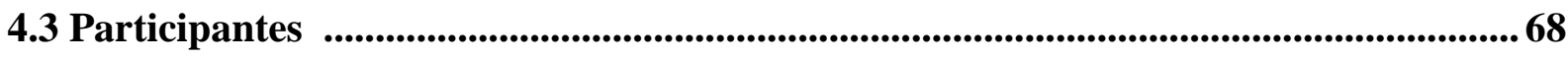

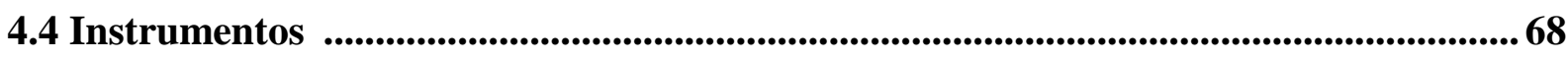

4.5 Análise dos dados .................................................................................................................. 70

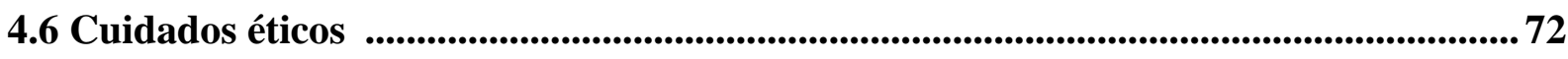

5 APRESENTAÇÃO E ANÁLISE DOS RESULTADOS .......................................... 74

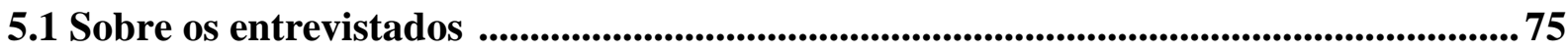

5.2 As consequências da estigmatização na vida social de pessoas com nanismo ............. 77

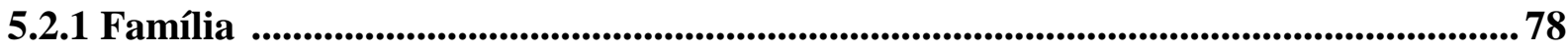

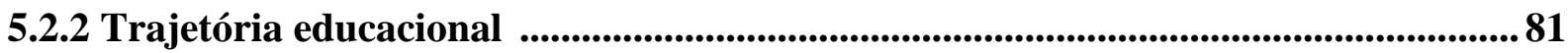

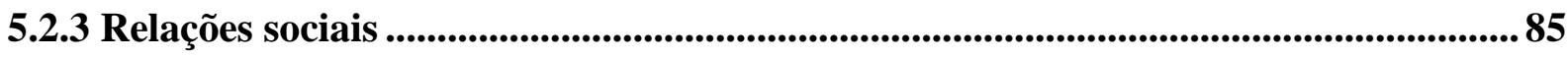

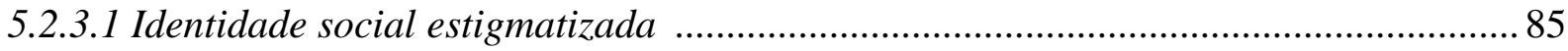


5.3 As consequências da estigmatização de pessoas com nanismo na esfera do trabalho 101

5.3.1 Vida de trabalho

5.3.1.1 Dificuldades de inserção no mercado de trabalho

5.3.1.2 Trabalho desprotegido

5.3.1.3 Influência dos estereótipos nas oportunidades de trabalho 112

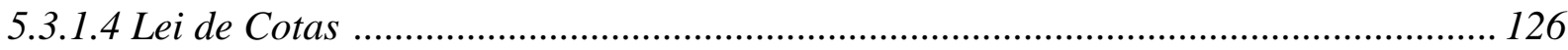

5.3.1.5 Humilhação e Preconceito no trabalho .................................................................. 128

5.4 Possibilidades de reconhecimento no trabalho ...................................................... 140

5.4.1 Reconhecimento ......................................................................................................................... 140

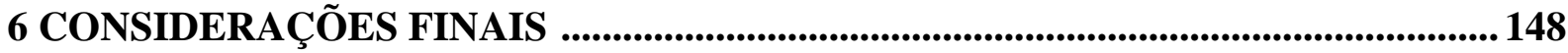

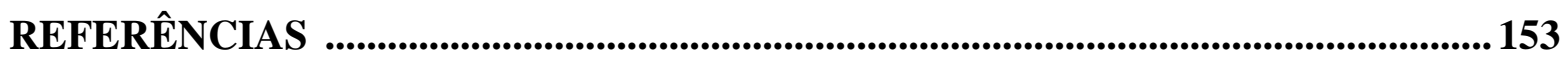

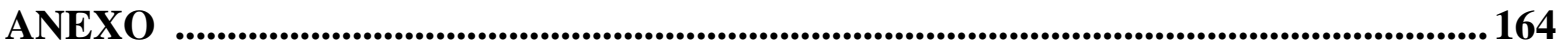


Apresentação 
O mercado de trabalho tem passado por transformações ao longo dos últimos anos. Segundo Oviedo e Czeresnia (2015), a mobilidade, o percurso descontínuo das trajetórias laborais e enfrentamento individual das contingências, são sinais das crises contemporâneas do mundo do trabalho, produzidas pela erosão dos sistemas de proteção social. Os trabalhadores, de modo geral, foram afetados por estas mudanças, mas as pessoas com deficiência constituem um grupo populacional mais exposto à vulnerabilidade.

Entre as barreiras que contribuem para a sua experiência de desvantagem estão a saúde mais precária, rendimento escolar inferior, menor empregabilidade e concentração em empregos que oferecem baixos rendimentos, maiores taxas de pobreza, maior dependência dos cuidados de outras pessoas, falta de vida em comunidade, dificuldades de acesso a meios de transporte e instalações públicas, além de experimentar atitudes negativas das demais pessoas, o que a isola das oportunidades sociais, culturais e políticas regulares (Relatório Mundial sobre a deficiência, 2012).

No sentido de minimizar os efeitos desta desvantagem e vincular o Direito ao Trabalho aos Direitos Humanos, a Convenção 111 da Organização Internacional do Trabalho (OIT), agência das Nações Unidas responsável pela formulação e aplicação das normas internacionais do trabalho, propôs a eliminação de todas as formas de discriminação em matéria de emprego e profissão como uma forma de garantir justiça social, encontrando sua promulgação no Decreto $\mathrm{n}^{\circ}$ 62.150, de 1968 (Brasil, 1968). Embora o Brasil seja membro da OIT, foi por meio do Decreto $\mathrm{n}^{\circ} 3.956$ (Brasil, 2001) que a ordem jurídica brasileira, tardiamente, se mostrou comprometida com a incorporação destes valores e princípios universais para eliminar todas as formas de discriminação contra as pessoas com deficiência e proporcionar sua plena integração à sociedade.

Por seu lado, grupos minoritários também passaram a reivindicar o direito ao trabalho, impulsionando a criação de leis para a garantia deste direito e convocando mudanças na forma em que a sociedade se organiza para a efetivação da inclusão, convivência e valorização das diferenças. Na diversidade de grupos populacionais historicamente mais atingidos pela exclusão social, como negros, indígenas, quilombolas, pobres, gays, transexuais, entre outros, as pessoas com deficiência receberam, através de Lei, a oportunidade de ingressarem no mercado formal de trabalho por meio da reserva de vagas destinadas exclusivamente para elas. A Lei $n^{\text {o }} 8.213$ (Brasil, 1991), regulamentada pelo Decreto nº 3.298 (Brasil, 1999), conhecida como Lei de Cotas, que obriga as empresas com mais de cem funcionários a terem de 2 a $5 \%$ de trabalhadores com deficiência ou reabilitados, foi decisiva para que a inserção delas fosse garantida. 
Mas o aumento progressivo do número de empregos formais de pessoas com deficiência (Departamento Intersindical de Estatística e Estudos Socioeconômicos [DIEESE], 2015), de todos os tipos, não foi efeito apenas da legislação. Isoladamente, ela não foi suficiente para positivar este direito, uma vez que muitas empresas passaram a alegar entraves para não contratarem, como a baixa escolaridade e a falta de preparo profissional destas pessoas (Almeida \& Vilela, 2011; Cançado, 2006; Ribeiro \& Carneiro, 2009). Se este grupo populacional historicamente foi submetido a processos de exclusão e segregação dos espaços de convivência construídos para a maioria, como poderiam ter construído as habilidades e competências exigidos no mercado de trabalho competitivo? Se suas trajetórias educacionais são interrompidas, irregulares, ou mesmo inexistentes, se os espaços de socialização são limitados devido à problemas que envolvem desde barreiras arquitetônicas, que comprometem o direito básico de locomoção, até condições culturais, que insistem em colocá-los em posição de menor valor para o mundo produtivo.

Diante de tantos estudos que já apontavam os problemas da inserção deste conjunto de trabalhadores nas organizações a partir do imperativo da Lei, o interesse de pesquisa durante o mestrado esteve voltado para a trajetória que antecede a esta contratação (Lima, 2012). Se não havia qualificação suficiente para o trabalho, então seria necessário investigar quais são os espaços de qualificação profissional ofertados para as pessoas com deficiência, para quais cursos, como eles se organizavam, segundo que perfil, se havia influência das empresas na construção dos currículos, se havia adaptações para este público específico ou não, método de seleção dos cursos, se havia intermediação da mão de obra, de onde partia a demanda para a escolha dos cursos a serem ofertados, regularidade deles, entre tantas outras perguntas que, como resposta, indicaram o quão distante ainda estamos do direito à igualdade de tratamento e de oportunidades para eliminação da desigualdade social e respeito à dignidade humana, como preconiza a OIT.

Os resultados obtidos apontaram que a educação profissional predominante é de nível básico, que ocorre em classes especiais e com maior oferta por parte das Organizações Não Governamentais (ONGs). No sistema S (Senai e Senac), a educação profissional é organizada e ofertada seguindo orientações da educação inclusiva, o que permite a convivência mista entre pessoas com e sem deficiência. No entanto, devido aos requisitos exigidos para os cursos, é pouco procurada por este público. Enquanto as ONGs prezam pela construção de um currículo voltado para a formação do indivíduo e desenvolvimento de suas habilidades para o trabalho, o sistema $\mathrm{S}$ direciona o currículo para todos, mas sem levar em conta as especificidades. Como cada ONG se especializa no atendimento de um tipo de deficiência, os 
recursos de aprendizagem são variados, enquanto no Sistema $S$, os recursos de aprendizagem vão sendo disponibilizados à medida que são demandados pelos alunos com deficiência. Assim como o Sistema $S^{1}$ existe para atender à demanda de suas conveniadas, as ONGs, responsáveis por formação e intermediação da mão de obra, ofertam cursos e escolhem previamente o perfil dos alunos de acordo com as escolhas de sua parceira. Entre outros resultados da pesquisa, estes apontaram que são as empresas que regulam o curso de qualificação que o futuro trabalhador com deficiência deverá receber, o tipo e o nível de deficiência que ele poderá possuir. Diante disso, a liberdade para projetar uma carreira profissional está sempre condicionada ao que o mercado reservou para ele.

Ao fim de uma investigação deste porte, em que tantas outras questões são abertas, descobre-se que ainda há muito por fazer, principalmente quando há o compromisso profissional com o trabalho docente desenvolvido na área de Gestão de Pessoas. Contribuir com a formação de gestores nas questões referentes à diferença, diversidade, inclusão, ao combate à discriminação, à promoção de igualdade de oportunidades no emprego, passa a ser um compromisso que vai além da atualização de conteúdos que contemplam a diversidade de pessoas nas organizações. É um compromisso pessoal com o processo de construção de uma cultura institucional de valorização das diferenças, da dignidade do trabalhador, da cidadania para todos e o enfrentamento da discriminação.

Foram os achados obtidos naquela pesquisa que tornaram viva uma suspeita de mercado de trabalho excludente. Ainda que se olhe por dentro dele, é o tipo de deficiência e o seu grau de severidade que organizam previamente os lugares e ocupações possíveis para cada pessoa. Disso resulta que nos cursos de capacitação custeados pelas empresas nas instituições de ensino, que também cumprem o papel de intermediadoras da mão de obra, há uma seleção prévia do perfil do futuro funcionário, o que limita a participação de pessoas com outras deficiências na aquisição de conhecimentos e concorrência por empregos, ainda que num mercado de trabalho exclusivo da "inclusão". Os números da inserção no mercado de trabalho divulgados pela Relação Anual de Informações Sociais [RAIS] (RAIS, 2014) mostram que pessoas com deficiência física estão em número muito maior que pessoas com outras

\footnotetext{
${ }^{1}$ Sistema S é o nome pelo qual ficou convencionado de se chamar o conjunto de nove instituições de interesse de categorias profissionais, estabelecidas pela Constituição brasileira. São eles: Serviço Nacional de Aprendizagem Rural (SENAR), Serviço Nacional de Aprendizagem Comercial (SENAC), Serviço Social do Comércio (SESC), Serviço Nacional de Aprendizagem do Cooperativismo (SESCOOP), Serviço Nacional de Aprendizagem Industrial (SENAI), Serviço Social da Indústria (SESI), Serviço Social do Transporte (SEST), Serviço Nacional de Aprendizagem do Transporte (SENAT) e Serviço Brasileiro de Apoio às Micro e Pequenas Empresas (SEBRAE).
} 
deficiências. Isto sem falar nas desigualdades de gênero e salariais. Fica evidente que para cada ação de inclusão, uma nova ação para exclusão é criada.

Portanto, a defesa de um estudo como este não encerra um processo de reflexão. Toda a realidade social que envolve tais questões continua a renovar o convite de aprofundamento para tantas outras perguntas e respostas que não couberam naquele estudo. As diferenças são tão diferentes que é preciso estar atento àquelas que lhe escaparam da consciência por tanto tempo. Foi no trabalho de atenção às diferenças das pessoas com deficiência que a questão atual se mostrou.

$\mathrm{Na}$ vasta literatura consultada no mestrado a respeito de pessoas com deficiência, educação, profissão, mercado de trabalho, exclusão, inclusão, diversidade, preconceito, entre outros temas, nenhuma referência à pessoa com nanismo foi encontrada. Na verdade, nem na bibliografia e nem durante todo o processo de inserção no campo tal questão foi pinçada. Em nenhuma das instituições que ofertavam cursos de qualificação profissional, entre todos os alunos vistos, em nenhuma das entrevistas realizadas em lugares públicos, de grande trânsito de pessoas com e sem deficiência, na maior cidade do país (São Paulo), foi possível acenar para uma pessoa com nanismo. Mas o trabalho na causa deixa uma vigília permanente, um estado de atenção curiosa propício a menores estímulos.

Foi numa escola de ensino básico que, ao observar o trânsito de alunos que vêm e vão, um aluno com nanismo disparou novas reflexões. Se encontramos tão facilmente em nosso cotidiano pessoas cegas, surdas, cadeirantes, com deficiência intelectual, por que não vimos pessoas com nanismo? Seriam poucas pessoas acometidas por esta deficiência? Estas foram as perguntas mais imediatas e que, posteriormente, geraram muitas outras.

Assim como não é corriqueiro encontrar muitas pessoas com nanismo na rua, pesquisas sobre o assunto também não trazem muitos resultados. "Anão" é uma palavra comum em mitos, lendas, fábulas, histórias conhecidas na infância, assim como podem adjetivar árvores, animais, planetas, entre outras coisas. Mas é comum invocarmos a lembrança guardada de uma pessoa com nanismo associando-a a um conto bastante conhecido: "Branca de Neve e os Sete Anões". Também é comum nos depararmos com uma destas pessoas em programas de auditório, no cinema ou teatro, desempenhando um papel que nos faz rir pela ridicularização a que são submetidas. Foi este ponto que gerou o maior incômodo. Por que não lembramos delas como pessoas comuns, como pai, mãe, advogado, professor, dentista, vendedor, ou outra profissão comum? Por que a lembrança que sempre vem à tona o liga ao exótico, ao riso, ao ridículo, à aberração, à sorte ou azar, e a tantas outras 
associações que o desqualificam como pessoas comuns e os colocam em posição de objeto ou de uma raça, um povo especial não pertencente à categoria de humanos?

As publicações científicas trazem muitas respostas em termos de achados clínicos. Muito se fala sobre causas, tipos, consequências, tratamentos e genética (Baujat, LegeaiMallet, Finidori, Cormier-Daire, \& Le Merrer, 2008; Cardoso, Ajzen, Santos, Fernandes, Costa, \& Oliveira, 2009; Chaudhary \& Bano, 2014; He, Horton, \& Hristova, 2010; He, Shobnam, Wimley, \& Hristova, 2011; Richette, Bardin, \& Stheneur, 2008). Pouco foi encontrado a respeito dos aspectos psicossociais relacionados à vivência com nanismo (Arenas \& Canal, 2016; Kruse, 2003; Ramírez, 2010; Rieser, 1992; Sandberg \& Voss, 2002), ao estigma social (Ablon, 1981, 1990, 2002; Arregui, 2008, 2009; Crocker \& Major, 1989; Fernández, Brascombe, Gómez, \& Morales, 2012; Gordon, Crouthamel, Post, \& Richman, 1982; Major \& O’Brien, 2005; Money \& Pollitt, 1966) e ao histórico de sua associação ao exótico (Adelson, 2005a, 2005b, 2005c; Backstrom, 2012; Durbach, 2009; Fordham, 2007; Manders, 2015; Warkany, 1973). Pouco se fala sobre trabalho, mercado de trabalho (Arregui, 2009; Tomé, 2014), motivo maior dos meus questionamentos. Sem dúvida, os aspectos macro da sociedade ajudam a pensar e explicar aspectos mais específicos da inserção deste grupo populacional, mas são tão poucos estudos sobre esse grupo de pessoas que, em todas as dimensões, é preciso saber mais.

Em função da ausência de publicações científicas sobre a temática a ser estudada, vídeos, depoimentos em jornais, revistas, disponibilizados na Web passaram a ser acompanhados. O conhecimento de associações de pessoas com acondroplasia (forma mais comum de nanismo) ao redor do mundo e no Brasil possibilitou conhecer melhor as demandas destas pessoas e o quanto é preciso saber mais sobre elas. Depois do contato virtual, veio a aproximação presencial com muitas pessoas do grupo virtual, selando um compromisso pessoal de maior responsabilidade, tanto na pesquisa quanto na proposição profissional de pensar esta diferença no âmbito pessoal, do próprio grupo social e da sociedade mais ampla. E, desta maneira, a presente proposta de pesquisa pôde ter seu início a partir do cotidiano das pessoas a serem estudadas.

Somado a isso, cria-se a expectativa de que os resultados de pesquisa também sejam utilizados pelas próprias pessoas com nanismo para suscitar reflexões e discussões que visam a construção de melhores experiências de vida. 
1.

Introdução 


\subsection{Nanismo: uma condição social de desrespeito}

A acondroplasia é a forma mais comum de displasia esquelética que provoca a baixa estatura desproporcional, conhecido como nanismo, afetando aproximadamente 250.000 indivíduos em todo o mundo (Bouali \& Latrech, 2015; Horton, Hall, \& Hecht, 2007; Narayana \& Horton, 2013). A incidência estimada é de cerca de 1 em cada 25.000 nascidos vivos em todo o mundo (Orphanet, 2017). No Brasil, ainda não há registros sobre a prevalência deste grupo populacional. De modo geral, a acondroplasia caracteriza-se como uma alteração genética autossômica dominante devido a um defeito na maturação da placa epifisária da cartilagem de ossos longos. Os autores apontam que mais de 95\% dos pacientes têm a mesma mutação pontual no gene para o receptor 3 do fator de crescimento de fibroblastos (FGFR3), e mais de $80 \%$ deles são novas mutações, o que justifica a ausência de características genotípicas da acondroplasia nos pais (Frade, Oliveira, \& Jesus, 2013; Gollust, Thompson, Gooding, \& Biesecker, 2003). Segundo He, Horton e Hristova (2010), a mutação no domínio trasmembranar do gene receptor do fator de crescimento do fibroblasto 3 (FGFR3) resulta na substituição do aminoácido glicina pela arginina na posição $380 \mathrm{em} 98 \%$ dos casos. O FGFR3 é um receptor de tirosina quinase que desempenha um papel importante no desenvolvimento dos ossos longos, levando a uma variedade de manifestações e complicações.

As características clínicas e radiológicas da acondroplasia podem ser facilmente identificadas. Segundo Bouali e Latrech (2015), Ramirez (2010), Shirley e Ain (2009) e Unger, Bonafé e Gouze (2017), elas incluem baixa estatura desproporcional, com a altura de uma pessoa adulta alcançando 130 centímetros, aproximadamente, encurtamento rizomélico (parte superior) dos braços e pernas, macrocefalia com protuberância frontal, hipoplasia da face média, hiperlordose lombar e cifose torácica, com abdome protuso. As mãos e dedos são curtos e com uma configuração de tridente no início da vida devido à incapacidade de opor totalmente o terceiro e o quarto dedo, testa proeminente, ponte nasal deprimida e hipoplasia maxilar. A mandíbula é ressaltada e grande em relação aos ossos da face, bem como os dentes são sobrepostos e mal alinhados, gerando má oclusão. Os ossos são a parte do corpo mais afetada. O tecido em torno dos membros geralmente não é afetado e continua a crescer normalmente, resultando em braços e pernas volumosos. No tronco, as dimensões longitudinais são normais, embora em algumas ocasiões ocorra diminuição do diâmetro anteroposterior, o que pode provocar dificuldades respiratórias e circulatórias. Alguns têm sérias consequências para a saúde relacionadas à hidrocefalia, compressão da junção 
craniocervical ou obstrução das vias aéreas superiores. O desenvolvimento cognitivo é considerado normal e a maioria dos acondroplásicos possui uma inteligência normal, sendo comum o atraso no desenvolvimento motor, principalmente na aquisição da marcha, devido à hipotonia muscular e à laxidão ligamentar. No entanto, muitas complicações sociais e médicas podem comprometer uma vida plena e produtiva.

A complexidade psicossocial de nanismo difere de outras condições incluídas sob a rubrica de incapacidade física devido a construções culturais socialmente existentes em torno de sua identidade e ao fato de que a maioria destas pessoas não tem severas restrições físicas em suas atividades. Money e Pollitt (1966) ressaltam que todos que entram em contato com um anão ${ }^{2}$, de forma impulsiva e intuitiva primeiramente engrenam reações e expectativas em relação ao seu tamanho, e não à sua idade. Apenas como um segundo pensamento, ou através da habituação, é que há a construção de um subsídio para a idade e a maturidade social. Mesmo em fotografias, a resposta social ao ver uma pessoa com tamanho de criança, mas com um físico precoce e maturação sexual, é de ambivalência e de estranheza inicial.

A partir do Decreto $\mathrm{n}^{\circ} 5.296$ (Brasil, 2004), elas passaram a compor o grupo de pessoas com deficiência física em razão da displasia esquelética. Além dos problemas de saúde ligados à condição clínica, pessoas com nanismo precisam lidar com vários obstáculos em seu cotidiano que vão além da acessibilidade. Na maioria dos casos, não é uma deficiência que deixa o corpo incapacitado, mas é uma deficiência diferente das demais pois, entre todas as pessoas com anomalias físicas, talvez não haja nenhum outro grupo cujo destino, em cada época, tenha sido moldado pela aparência do seu corpo (Ablon, 1990; Adelson, 2005a; Kruse, 2003). Conjugadas todas a lutas de pessoas com deficiência, do tipo física, ainda existem outras específicas, relacionadas às ações discriminatórias por sua estigmatização social. Já na

\footnotetext{
${ }^{2}$ Dwarf é o termo utilizado na língua inglesa por autores para se referir às pessoas com nanismo. Significa anão, anã, pigmeu, planta ou animal menor do que o tamanho normal, personagem de contos de fadas de estatura muito baixa e de poder sobrenatural (Dicionário Michaelis online). Neste trecho, o termo utilizado pelo autor foi originalmente mantido. Em razão deste significado, o termo "anão" sofre forte resistência, sendo recomendados pelas organizações destas minorias a utilização dos termos "pessoas de baixa estatura" ou "pequenas pessoas". No Brasil, ainda não há um posicionamento a este respeito, mas optamos por seguir a recomendação de Manders (2015). Segundo o autor, os rótulos aplicados a pessoas com crescimento limitado causado por uma condição médica subjacente variam e podem ser vistos como áreas de contestação. O termo "pessoas pequenas" sofre rejeição por sua extensão a qualquer pessoa com baixa estatura, criança ou adulta, embora não seja afetada pela acondroplasia. Portanto, não corresponde à realidade. "Anão" e "povo pequeno" tem raízes no folclore germânico e celta, o que prolonga a associação ao folclore e à mitologia. "Pessoa pequena" também não é um termo bem recebido. Mães entrevistadas pelo autor questionaram porque se as crianças com progéria (condição genética em que os sintomas se assemelham ao processo de envelhecimento, manifestando-se nos primeiros anos de vida) não são chamadas de duendes, por que o termo "anão" seria adequado para se referir a seus filhos? Por estas construções sociais a respeito da identidade de quem possui acondroplasia, seguiremos a recomendação do autor, que utiliza o termo "pessoas com nanismo" ou "pessoa com nanismo". Em alguns trechos deste trabalho poderá ser encontrado o uso destas outras palavras citadas anteriormente, de forma a obedecer ao termo empregado nas literaturas consultadas.
} 
infância, estas pessoas percebem que seu aspecto físico provoca risos, olhares, comentários e atitudes que depreciam sua pessoa. Um dos âmbitos mais visíveis de discriminação é o social, quando suportam uma carga de clichês e conotações culturais que associam sua imagem à de um ser cômico, grotesco, resultando em uma percepção de exclusão e sentimentos de humilhação social (Garcia, 2010).

Ao longo da história, muitos estereótipos, até ambíguos, foram construídos em relação a estes corpos identificados como anatomicamente incomuns, que desviam da normatividade. Ao fazer um resgate histórico a respeito das representações de pessoas com nanismo, Ablon (1984), Adelson (2005a) e Gerber (1992) descrevem que mesmo antes de haver uma história escrita a respeito de anões, suas imagens apareciam no trabalho artístico de muitas culturas. Eram considerados artefatos no Egito, Índia, China, Grécia, Roma, civilizações maias e outras culturas, ora atribuindo-lhes papeis especiais de divindades, bobos da corte, acrobatas, guardiões de joias e objetos preciosos, ora discriminando-os como símbolo de maus presságios ou abominações, símbolos da fertilidade, maldade e bondade, ligando-os a poderes mágicos e divinos. Eram tratados como objeto de coleção da nobreza e de satisfação do apetite da realeza para a violência e lascívia, atrações de circo, animais de estimação e mascotes de pessoas poderosas e prestigiadas, ofertadas como presente entre os membros de antigas cortes reais, exibidas como objeto de coleção ou em espetáculos para entretenimento, tendo um papel de destaque em lendas e mitos. Nos contos de fadas e literatura, proliferava a ideia de que uma pessoa com nanismo tem conexões com coisas que não pertencem ao plano terrestre. Sem inserção em ocupações tradicionais à maior parte da população, o trabalho com música, formando trupes itinerantes que levavam entretenimento às outras pessoas e a formação de aldeias, contribuiu para perpetuar a ilusão de que elas formam uma feliz comunidade ou mesmo um "povo" (Ablon, 1981, 1990, 2002; Adelson, 2005a, 2005c; Kruse, 2003).

Segundo Bogdan (1988), embora as primeiras exibições de pessoas com corpos anômalos para entretenimento tenham começado há muito tempo, o chamado "freak show" alcançou muita popularidade como uma característica de circo itinerante no final do século XIX e início do século XX. Para o autor, "Freak" é um modo de pensar, de apresentar, um conjunto de práticas, um quadro da mente, e não uma característica de um indivíduo. E um freak show é uma exibição formalmente organizada de pessoas com alguma anomalia física, mental ou comportamental, para a diversão e lucro (Bogdan, 1988, p. 10). Se inicialmente estes shows apresentavam "curiosidades humanas", depois eles evoluíram para eventos altamente lucrativos em circos, feiras, carnavais e parques de diversões. Para aumentar a 
curiosidade e o interesse do público, os espetáculos usavam estratégias de promoção e apresentação que criavam uma identidade pública da aberração através de imagens e símbolos (Backstrom, 2012; Bogdan, 1988). Mesmo com anomalias verdadeiramente raras, as apresentações eram sempre exageradas para tornar as exposições mais atraentes para o público. "Toda exibição era uma fraude... toda pessoa era deturpada ao público" (Bodgan, 1988, p. 10).

Para o autor, a única razão que torna alguns indivíduos um "freakfied", é que eles não se encaixam em um molde que a sociedade construiu para eles, o que torna este termo, "freak", uma construção social. Considerados "anormais", eles não se encaixam no molde da sociedade e são forçados a criar um novo para si, podendo encontrar conforto no meio de outros com características singulares e até lucrar com suas deformidades e "anormalidades".

De acordo com Bogdan (1988), estes shows foram desmitificados com o desenvolvimento da medicina moderna e uma melhor compreensão das causas subjacentes dos desvios da normalidade. O aumento do conhecimento médico diminuiu problemas relacionados ao parto, o tratamento melhor das condições clínicas, a maior exposição das pessoas a diferentes culturas, o surgimento de novas formas de entretenimento, como filmes e televisão, que substituíram o circo itinerante, além do empenho de movimentos sociais que reclamavam os direitos dos grupos minoritários, são fatores que contribuíram para questionar práticas que colocam a pessoa com deficiência como uma aberração.

Mas até hoje os ecos do passado se fazem presentes. Se durante séculos sua história de vida foi permeada pela exposição social que o remetia à ridicularização e objetificação a despojo de seus senhores e de espetáculos de entretenimento, as representações contemporâneas ainda carregam muito desta imagem (Adelson, 2005; Bogdan, 1988; Thomson, 1996). Sua influência pode ser sentida na cultura moderna, predominantemente na indústria do entretenimento, que ainda convoca à elaboração performativa estes corpos anômalos, quando a diferença é celebrada. Entre os grupos exibidos nestes espetáculos, de ontem e de hoje, as pessoas com nanismo continuam incluídas.

Uma performance culturalmente estereotipada é premeditada para que representem papeis de "anões da Branca de Neve", para serem a atração exótica de festas e participarem de eventos como mascotes utilizando trajes bizarros em jogos. Também são comumente encontrados em festas de rodeio, quando desempenham o papel de toureiro ou palhaço, para domar ou distrair um animal feroz. O "arremesso de anões" tornou-se bastante conhecido, sobretudo em países desenvolvidos como Austrália, Espanha, Estados Unidos e França. É considerado um "esporte de bar" no qual uma pessoa com nanismo usa um colete para que 
uma pessoa maior (cliente, "pessoa normal”) possa arremessá-lo o mais longe que conseguir. Costuma ser uma competição e ganha quem conseguir atirar o objeto (pessoa com nanismo) mais longe que os concorrentes (Reuters, 2002). Como aponta Chiesse (2014), ganhou notoriedade no Brasil o programa Pânico na TV, onde o elenco, que inclui pessoas com nanismo, também é submetido ao vexame e à exposição do corpo como objeto de lascívia, ao tratamento como mero objeto, a sofrimentos emocionais e físicos, como uma forma de fazer humor. São trabalhos com alto potencial de humilhação, desconforto, depreciação, que violam a dignidade humana e que ainda colocam suas vidas em risco. Como afirma Conroy (2012), o corpo anômalo proporciona a ocasião para o desempenho.

Sabe-se que, independentemente do pano de fundo socioeconômico, a primeira identidade projetada é a de "anão" (Ablon, 1981), culturalmente construída ao longo dos séculos. A construção simbólica a respeito do seu corpo é central nesta experiência da diferença, cuja anormalidade se inscreve em um regime de visibilidade mais próximo do exótico. Um médico, advogado, professor, que é menor que uma criança, ainda evoca curiosidade, provoca zombaria e desrespeito da parte de outras pessoas. É como se o seu corpo não pudesse ser entendido fora do lugar culturalmente construído para ele (Kruse, 2003), cabendo-lhe cumprir o papel de uma caricatura, uma "aberração estereotipada" (Adelson, 2005a), em atividades de entretenimento que exploram preconceitos em razão de sua aparência e perpetua sua imagem associada ao risível, vitimando mais uma vez este corpo já subestimado socialmente e contrariando os esforços de minorias para desconstruir as imagens da deficiência que tradicionalmente dominam o palco, a tela e a sociedade.

Mas a pessoa com este corpo reivindica um lugar no mercado de trabalho que não seja restrito ao meio artístico, onde encarna uma personagem. Embora faltem estudos que apoiem a discussão a respeito do trabalho e emprego, é comum encontrar depoimentos destas pessoas insatisfeitas com a discriminação também no contexto do trabalho (Cunha, 2015; Nomura, 2006). No espaço intragrupal, há posições diferentes a respeito de trabalhos estereotipados, que violam tanto a dignidade da pessoa que se submete ao trabalho, quanto do grupo populacional que ela representa. Para alguns, eles contribuem por denegrir todo um grupo social já estigmatizado historicamente e aprofunda crenças arraigadas que atingem todas as outras pessoas com esta condição, comprometendo as possibilidades de inclusão em carreiras profissionais mais comuns na sociedade em igualdade de condições. Para outros, é um trabalho como outro qualquer, demandado pelo mercado de trabalho e que lhes garante uma remuneração. Afinal, que mal há se ganham a vida como palhaços, fazendo rir? Os palhaços não seriam dignos? Há mal em fazer rir? Nesta contenda ainda entram as dificuldades 
encontradas na busca por um emprego tradicional, o que faz com que eles disponham a sua diferença à "indústria moderna de diversão de massa" (Courtine, 2008, p. 256), em programas que exploram excentricidades, em um tipo de "consumo midiático do corpo diferente" (Carrascoza, Casaqui, \& Hoff, 2011, p. 197).

Estas reproduções culturais, que associam sua identidade ao trabalho artístico, acabam repercutindo nas possibilidades de inserção ocupacional em trabalhos tradicionais. Enquanto muitos fazem do estigma sua profissão, outras pessoas com nanismo buscam inserção no mercado de trabalho pela via do emprego tradicional. Este último caminho tem sido facilitado por meio de ações afirmativas que visam garantir a inserção de pessoas com deficiência no mercado formal de trabalho, através da Lei $\mathrm{n}^{\circ} 8.213$ (Brasil, 1991), conhecida como Lei de Cotas. Embora a lei seja do ano de 1991, somente com o Decreto nº 5.296 (Brasil, 2004) é que o nanismo foi incorporado no grupo de deficiências físicas.

De maneira geral, faltam estudos que apoiem uma discussão a respeito de trabalho quando se toma como análise este grupo populacional. $\mathrm{Na}$ busca bibliográfica realizada durante o período desta pesquisa em bases de dados como Medline e PubMed, PsycInfo, Web of Science, Scopus, Springer utilizando os termos "short stature", "restricted growth", "skeletalDysplasia", "achondroplasia" e "dwarf' trouxeram como resultados uma concentração de estudos nas áreas da saúde e, em menor proporção muito menor, na área da psicologia social que estuda estigma e deficiência de modo geral. O termo "dwarf" ou “dwarfism", "anão" ou "nanismo" na base Scielo também foi utilizado, trazendo resultados relacionados à área clínica e à botânica, onde é comum o emprego do termo para denotar o baixo crescimento de plantas.

Mesmo na literatura internacional, pode-se afirmar que ainda se sabe pouco a respeito da situação de vida destas pessoas. As pesquisas estão mais concentradas em questões clínicas e voltadas para a causa e tratamentos que amenizam as complicações decorrentes da mutação do gene causador do baixo crescimento e tratamento de alongamento ósseo (Cardoso, Ajzen, Santos, Fernandes, Costa, \& Oliveira, 2009; Chaudhary \& Bano, 2012; Baujat, Legeai-Mallet, Finidori, Cormier-Daire, \& Le Merrer, 2008; He, Horton, \& Hristova, 2010; He, Shobnam, Winley, \& Hristova, 2011; Richette, Bardin, \& Stheneur, 2007), vida social (Ablon, 1984, 1988, 1990; Adelson, 2005b), estigma e consequências psicossociais da baixa estatura e identidade social (Ablon, 1981, 2002; Arregui, 2009; Crocker \& Major, 1989; Fernández, Brascombe, Saguy, Gómez, \& Morales, 2014; Fernández, Brascombe, Gómez, \& Morales, 2012; Gollust, Thompson, Gooding, \& Biesecker, 2003; Gordon, Crouthamel, Post \& Richman, 1982; Kruse, 2003; Money \& Pollit, 1966; Sanderberg \& Voss, 2002) e 
representações culturais a respeito do nanismo (Adelson, 2005a; Backstrom, 2012; Stephens, 2005; Thomson, 1991). Tais estudos foram desenvolvidos basicamente na Espanha e na América do Norte, onde estão localizadas as organizações de apoio a pessoas com nanismo mais conhecidas no mundo.

Fernández, Brascombe, Gómez e Morales (2012) estudaram o papel de organizações de pessoas com nanismo no enfrentamento da estigmatização em dois países, Estados Unidos e Espanha. No primeiro, a Little People of America (LPA), atuante desde 1957, está focada em facilitar o desenvolvimento de uma identidade comum de que todos os membros possam se orgulhar, enquanto no segundo, a fundação ALPE, desde o ano 2000, foca em orientação médica, com ênfase em cirurgias de alongamento ósseo com objetivo de eliminar o nanismo. Como não há esforços para encorajar o contato intragrupal, na Espanha, as pessoas com nanismo estão mais propensas a experimentarem a rejeição como indivíduos desviantes, enquanto os americanos se consideram membros de uma minoria ${ }^{3}$. Ablon $(1981,2002)$ também cita o trabalho da LPA no processo de mediar a aceitação e valorização da identidade da pessoa com nanismo.

Quanto à situação deles no mercado de trabalho, Tomé (2014) fez uma dissertação de mestrado onde buscou compreender, por meio de questionários e entrevistas por telefone, o modo de inserção no mercado de trabalho de Portugal. Os resultados mostraram que pessoas com nanismo com reduzidas qualificações enfrentam maiores obstáculos para serem contratadas, especialmente devido às poucas oportunidades de emprego na região onde residiam. Independentemente do nível educacional, a maioria dos entrevistados empregados tinham relações de emprego estáveis e se sentiam estigmatizados por atitudes negativas dos empregadores. Não foram relatadas situações de discriminação e receios quanto ao futuro profissional. Na pesquisa aqui proposta, não há preocupação com uma caracterização das formas estruturadas de inserção no mercado de trabalho com que se deparam estes trabalhadores com nanismo, mas sim com aspectos mais amplos da vida de trabalho deles.

A ausência de mais estudos nesta área do trabalho nos permitiu considerar tais questões relevantes e abrangentes para compreender os problemas enfrentados por estas pessoas ao chegarem na idade adulta, quando necessitam de um trabalho como fonte de renda para viver. Diante da complexidade que envolve o estigma da pessoa com nanismo ao longo

\footnotetext{
${ }^{3}$ Desviantes são aqueles que sofrem discriminação estável e estão isolados de outros que compartilham seu destino, enquanto que as minorias clássicas não são tipicamente isoladas de outros membros do grupo e percebem que a discriminação é compartilhada pelo grupo como um todo (Jetten et al., 2006 apud Fernández, Brascombe, Gòmez, \& Morales, 2012).
} 
de sua vida, numa época em que se fala de direitos humanos, respeito à diversidade e inclusão social, tomando o emprego formal como uma das principais vias para isto, surgem muitas questões relevantes. Se durante todo o seu desenvolvimento as pessoas com nanismo precisam lidar com a estigmatização, ao chegarem na vida adulta e no mundo do trabalho, isso muda? As consequências da estigmatização na vida social repercutem na esfera do trabalho? Que consequências o estigma traz para a pessoa na esfera do trabalho? Como lidam com isso? A partir destas questões básicas este estudo foi delineado.

Durante todo o desenvolvimento de uma pessoa com nanismo, as interações sociais são marcadas por emoções relacionadas à sua exposição no espaço público como uma pessoa diferente. Sua diferença evoca diferentes reações nas pessoas, geralmente desagradáveis para a própria pessoa com nanismo. A cada novo contato social, renova-se a experiência de conhecimento do seu estigma. Angústia, nervosismo, preocupação, ansiedade, podem deixa-la pouco à vontade em novas interações que podem chegar ao seu ápice na idade adulta, no momento de inserção no mercado de trabalho. A formação profissional, a busca e competição por um trabalho, podem gerar forte tensão para o indivíduo em razão da necessidade de construção de novas interações e a expectativa de suas consequências.

Por isso, o objetivo deste trabalho é compreender a vida de trabalho para pessoas com nanismo através de uma análise psicossocial e identificar e discutir possibilidades de estigmatização e reconhecimento através do trabalho. Ancorada na Psicossociologia, este estudo utiliza como campo de investigação a articulação entre campo social, condutas humanas e vida psíquica (Lhuilier, 2014). Para a autora, a Psicossociologia não atribui um lugar central ao trabalho, às atividades do sujeito sobre e no mundo, mas está mais centrada nas dimensões relacionais das experiências profissionais. São estas experiências construídas pelos sujeitos em sua interação no mundo do trabalho que se constituem o campo para esta investigação. Com base nesta fundamentação teórica, o psicossocial ${ }^{4}$ foi compreendido, nesta Tese, como algo que "não é nem subjetivo, nem social, mas os dois simultaneamente, materializados no relacional" (Ribeiro, 2017, p. 270).

Até aqui, foi apresentado um panorama mais geral a respeito da condição social da pessoa com nanismo, de modo a situar as particularidades desta diferença em relação às

\footnotetext{
${ }^{4}$ Psicossocial: na definição de Ribeiro (2011, p. 56), é a "construção contínua e compartilhada, não um ajustamento ou adaptação de um indivíduo (processo subjetivo) a uma realidade (processo social), ambos compreendidos não como processos delimitados e separados, mas sim um único processo visto como elo de continuidade do subjetivo ao social e vice-versa, polos extremos de uma mesma estrutura processual global, que é produzida em relação dialética, pois se constitui como produto e produtora da própria relação, relação de dupla transição: do subjetivo ao social e vice-versa, num movimento contínuo. A estrutura é sempre processual, nunca substantiva".
} 
demais pessoas com deficiência. A seguir, os elementos que fundamentam teoricamente esta condição serão abordados. O corpo em sua diferença evidente, que suscita um estigma e aciona formas de desrespeito e humilhação social, a reivindicação do direito ao trabalho e ao reconhecimento, serão temáticas discutidas a seguir. Na sequência, encontra-se a descrição do método utilizado nesta pesquisa. Á frente, os resultados encontrados serão apresentados em concomitância à sua análise. Por se tratar de um estudo qualitativo que priorizou compreensões da realidade feita pelos participantes, serão tecidas considerações ao final. 
2.

Fundamentação Teórica 


\subsection{Nanismo: da estigmatização à humilhação social}

As dificuldades de se viver com nanismo não estão circunscritas apenas aos desafios relacionados a ser pequeno em uma sociedade construída para uma maioria de estatura maior, o que se traduz, no cotidiano, em dificuldades de acessibilidade. Também não se limita ao enfrentamento dos problemas de saúde ligados à sua condição de displasia. Como não se pode dissimular a sua corporeidade distintiva, a identidade imediatamente projetada é a de "anão", personagem de baixa estatura que habita o imaginário social como um gnomo, duende, palhaço, enfim, alguém que ocupa o palco do teatro, cinema e televisão para fazer a plateia rir da sua aparência.

Esta elaboração social e cultural que habita o imaginário da sociedade marca individual e coletivamente o modo de viver das pessoas com nanismo. É o corpo, em seus aspectos físicos, que se constitui como "fonte de estigma e locus de sofrimento psicológico nos processos interativos" (Fernandes \& Barbosa, 2016, p. 70). É ele que suscita a colocação do indivíduo em mediação com uma categoria social ou moral ao estar sujeito a regimes de normatividade, desencadeando processos sociais que resultam em uma apreciação exterior do corpo como menosprezado, apreciado, rejeitado, sofrido (Ribeiro, 1996).

Por esta razão, este estudo se apoiará numa área do conhecimento denominada Sociologia do Corpo que, segundo Le Breton (2006), pesquisa as lógicas sociais e culturais que se propagam no corpo, os imaginários sociais do corpo e o corpo no espelho do social. Esta relação triádica entre físico-social-cultural está coadunada com as particularidades da experiência de vida do grupo populacional estudado.

Para o autor, antes de qualquer coisa, a existência é corporal. O corpo, inserido em um contexto social e cultural, é um vetor semântico através do qual ocorre a construção da relação com o mundo. O corpo é o primeiro e mais natural instrumento do homem e é pela mediação dele que se dá o intercâmbio social no cotidiano de cada pessoa. Os usos físicos que se faz deste corpo dependem de um conjunto de sistemas simbólicos que obedecem a uma simbologia própria da comunidade social a que pertence, fazendo dele uma superfície de projeção de valor e de imaginários.

Considerando as pessoas com nanismo, o seu corpo, embora anômalo, estranho a outras pessoas, é familiar à imagem cultural e socialmente projetada sobre o exótico. A sua presença se reduz à presença do seu corpo. "Ele é o seu corpo. A Anatomia é seu destino" (Le Breton, 2006, p. 63). O modo como o corpo físico é percebido é condicionado pela categoria 
social ao qual ele pertence. Então, a sua diferença, evidenciada pela deformidade física, é transformada em estigma.

Esta característica distintiva que suscita à imposição de um estereótipo que desvaloriza o indivíduo como ser total remete à discussão tecida por Goffman (2012) a respeito da manipulação da identidade deteriorada. Para o autor, o termo estigma refere-se a um atributo profundamente depreciativo inserido em uma relação com o estereótipo. Quando um indivíduo que está à nossa frente apresenta uma característica distintiva dos outros, imediatamente evidente, impossível de esconder, o meio social estabelece a categoria a qual ele deveria pertencer. Se este atributo gera descrédito social, deixamos de considerar a pessoa em sua totalidade, reduzindo o seu valor e afetando as possibilidades de sua aceitação plena no seio das relações sociais cotidianas. $\mathrm{O}$ traço que o distingue compromete a atenção a seus outros atributos e na superfície do seu corpo passam a ser projetadas uma série de inferências deduzidas a partir da imperfeição original. Os sinais corporificados de estigma dão a conformação da identidade social.

Para Goffman (2012), as crenças que a sociedade mantém a respeito de sua identidade são incorporadas pelo indivíduo estigmatizado, tornando-o intimamente suscetível ao que os outros veem como seu defeito. A imagem de si é construída a partir do mesmo material que as outras pessoas utilizam para considerar sua identidade social, embora tenha liberdade para elaborar de diferentes maneiras. O social e o cultural influenciam a construção e a percepção de si, ou seja, no modelo de identidade que aplica a si mesmo. No caso da pessoa com nanismo, ela já sabe a categoria que será colocada em virtude do seu pertencimento a um grupo social cujo estigma é padronizado socialmente - anões -, alvo dos mesmos estereótipos ao longo do tempo.

Na encarnação deste modelo, o indivíduo poderá enfrentar ambivalência em relação a seu próprio eu. A consciência da diferença exótica que o inferioriza pode provocar vergonha, insegurança, ansiedade, medo de não ser aceito e respeitado pelos outros, comprometendo a sua percepção de segurança em relação à maneira como os "normais" o identificarão e o receberão.

Para Le Breton (2006) e Goffman (2012), a pessoa com deficiência remete ao imaginário do corpo desmantelado, que cria uma desordem na segurança ontológica que garante a ordem simbólica na sociedade. Quando o defeito da pessoa estigmatizada é evidente, atrai olhares e comentários, discursos e emoções, sendo provável que ela sinta a sua privacidade invadida pela observação fixa e uma curiosidade mórbida sobre a sua condição. 
O homem que sofre de uma deficiência visível, quanto a ele, não pode mais sair de casa sem provocar olhares de todos. E quando ousa fazer qualquer passeio, é acompanhado de uma multidão de olhares, frequentemente insistente. São olhares de curiosidade, incômodo, angústia, compaixão, reprovação. Como se o homem que tem uma deficiência tivesse que suscitar de cada passante um comentário (Le Breton, 2006, p.73).

Como ressalta Goffman (2012), a familiaridade das pessoas com uma categoria de estigmatizados não reduz necessariamente o menosprezo. Quanto mais visível a deficiência, mais suscita a atenção social indiscreta, comentários e gestos sociais, afetando duramente seu cotidiano, traduzindo-se numa "violência tão mais sutil que ela não se reconhece como tal e se renova a cada passante que é cruzado" (Le Breton, 2006, p. 75). Então, as situações sociais do indivíduo visivelmente estigmatizado frente a um mundo não receptivo afetam o seu bemestar psicológico.

Como não se pode disfarçar a anatomia de ter nanismo, a apresentação física de si parece valer socialmente pela apresentação moral (Le Breton, 2006). Partindo do corpo, de sua aparência, o olhar apreciativo aciona o sistema de referência de cada pessoa, que passa à fase de categorização de quem está à sua frente, enquadrando-a em algum tipo de "moldura pronta" (Bergson, 2007, p.132). O que um indivíduo é, ou poderia ser, deriva do lugar que os seus iguais ocupam na estrutura social (Goffman, 2012).

Arregui (2009), que em sua tese de doutorado estudou as consequências do estigma social do nanismo ósseo e as estratégias de enfrentamento, aponta que as pessoas com nanismo enfrentam, praticamente todos os dias de sua vida, olhares indiscretos nas ruas, acompanhados de risadas, brincadeiras, provocações e menosprezo. Esta resposta social à exposição do seu corpo na rotina diária começa desde a infância, quando, na escola, frequentemente tem dificuldades para ser aceita pelos companheiros em igualdade de condições, constituindo-se como uma ameaça à capacidade de estabelecer vínculos de pertencimento. À medida que as necessidades de uma vida comum exigem o alargamento dos laços sociais, maior será a sua exposição à estigmatização.

Sem fantasia, disfarces, é como se este corpo, por si só, tivesse o poder de fazer rir. As risadas são decorrentes do fato de serem percebidos pela sociedade de forma pejorativa, o que se relaciona com a marcação cultural socialmente construída pela sociedade para esta condição física ao longo dos séculos. São heranças de outros tempos, que vinculam o presente deste grupo populacional a estereótipos criados no passado. Para Goffman (2012), acredita-se que alguém com um estigma não seja completamente humano, pois deixamos de considerá-la em sua totalidade para reduzi-la a uma pessoa estragada e diminuída. Independentemente do 
palco teatral, numa encenação intencionalmente programada para ser bizarra, intencionalmente pensada para "fazer rir", tomada como mercadoria, as pessoas com nanismo também precisam lidar com as risadas e brincadeiras pejorativas em suas experiências sociais mais corriqueiras. Seus corpos, considerados exóticos, excêntricos, ao invés de provocar piedade e compaixão, como em outras deficiências, suscita o riso e atração.

Apesar de reduzir a pessoa em sua totalidade em razão do estigma, ela continua carregando atributos que conservam suas características humanas. É aí que entra a comicidade associada ao grupo. É preciso buscar em Bergson (2007) o apoio para esta compreensão. Como o próprio autor reconhece, "é incontestável que certas deformidades têm em relação a outras o triste privilégio de, em certos casos, provocar o riso" (p.17). Existe uma fisionomia cômica, uma deformidade risível, o que faz da pessoa com estas características risível.

Uma lógica da imaginação, que não é a lógica da razão, é a fonte da comicidade. Como afirma Bergson (2007), "rimos sempre que uma pessoa nos dá a impressão de coisa" (p .43), como uma transfiguração momentânea de uma pessoa em coisa. A forma cômica dessa coisa só pode ser entendida graças à semelhança com outra, que também nos faz rir. Daí que todo o simbolismo presente em histórias e encenações estereotipadas, e a sua atualização, se fazem repercutir até hoje na imagem da pessoa com nanismo como um ser risível, cujo destino natural é esse.

Para ele, acima de tudo, a comicidade exprime uma inadaptação particular da pessoa à sociedade, que se vinga por meio do riso. Para uma pessoa ser considerada ridícula é preciso que ela esteja em contraste com as expectativas modeladas pelo ambiente. Alguma coisa que vive nela, e não se organiza com ela, torna-se alvo da atenção social. A função social do riso é, portanto, reprimir esta inadaptação, é fazer uma correção através da humilhação que ele causa para quem é seu objeto. Feito para humilhar, ele deve dar uma impressão penosa à pessoa a quem se dirige. "O riso é de fato uma espécie de trote social” (Bergson, 2007, p. 101).

$\mathrm{O}$ riso castiga certos defeitos mais ou menos como a doença castiga certos excessos, atingindo inocentes, poupando culpados, visando a um resultado geral sem poder fazer a cada caso individual o favor de examiná-lo separadamente... Nesse sentido, o riso não pode ser absolutamente justo. Repetimos que ele também não deve ser bondoso. Sua função é intimidar humilhando. Não conseguiria isso se para esse fim a natureza não tivesse deixado nos melhores homens um fundinho de maldade, ou pelo menos de malícia (Bergson, 2007, p. 147).

Na cena pública, sua presença recebe a atenção traduzida em riso, tal como um objeto que está disposto para receber a apreciação e o julgamento de quem assim desejar. Por isso, a 
humilhação é mais um elemento que se junta à experiência social da pessoa com nanismo. Arregui (2008), Bentes (2010), Fernández, Saguy e Halperin (2015), Gonçalves Filho (1998, 2003, 2007), Hartling, Lindner, Spalthoff e Britton (2013), Hartling e Luchetta (1999), Klein (1991, 2004, 2005), Kuch (2010), Lazare (1987), Lindner (2001), Margalit (1996), McCauley (2017), Miller (1995), Piroli (2016) e Statman (2000) oferecem reflexões que ajudam a pensar a humilhação social. Seus elementos estão diretamente ligados ao repertório cultural da sociedade em análise e integram, num só drama, quem humilha e quem é humilhado.

Para Klein (1991, 2004, 2005), Hartling, Lindner, Spalthoff e Britton (2013), e Hartling e Luchetta (1999), apesar da humilhação social ser uma experiência universal em nossa sociedade, apenas há pouco tempo ela tem recebido atenção para maiores estudos. Como um problema político e psicológico, é um fenômeno emocional complexo em que o humilhado vive situações reais de rebaixamento, de impedimento para a sua humanidade que se desdobram em si mesmo, no seu mundo (Gonçalves Filho, 2007). Nos relatos de pessoas sobre a experiência de ser humilhado, Klein (1991) descreve que estão presentes o sentimento de aniquilamento, desamparo, confusão, paralisia e raiva, como se fossem feitos pequenos, indo do sentimento de encolhimento até o desaparecimento.

O passar dos anos não minimiza a lembrança, que continua viva e fresca na memória. Segundo Klein (1991), quando a pessoa é humilhada, há uma ameaça à sua integridade pessoal, a diminuição do seu valor social aos olhos dos outros e até mesmo a exclusão do humilhado do círculo de convivência de quem perpetra a humilhação. Como sofrimento que persiste, resiste e se renova ao longo do tempo, a humilhação social vai sendo somada a gestos e palavras de rebaixamento da sua pessoa lançadas em cena pública, que penetram e permanecem no corpo e na alma do rebaixado (Gonçalves Filho, 2007).

Se no pretérito a humilhação de uns sobre outros era considerada necessária para estabelecimento e manutenção de sistemas hierárquicos de desigualdade estruturada, como um sinal de obediência à ordem social vigente e aceita, baseada em honra e posição, com o passar do tempo o seu significado foi ganhando conotação negativa, como apontam Linder (2009, 2011) e Miller (1993). Essa transição foi marcada pela Declaração Americana de Independência (1776), a Revolução Francesa (1789), o surgimento do eu individualizado, a consciência de que a Terra é o lar da humanidade e o advento dos ideais de direitos humanos, que contribuíram para que o significado social do conceito de humilhação fosse entendido como uma violação dos direitos de um indivíduo e de sua dignidade, alcançando uma profunda e persistente violação relacional em todos os níveis, desde o interpessoal, social, até 
o internacional. (J. B. Miller, 1987; Hartling, 1996; Hartling \& Lucketta, 1999; Lindner, 2001, 2006, 2009, 2010).

Etimologicamente, a palavra humilhar vem do latim humiliare, que tem o sentido de abaixar a confiança, o estatuto de outra pessoa. Sua raiz é a palavra humiliare, que significa baixo ou rente ao chão, como uma planta rasteira, que seria humilis. No sentido mais metafórico, humilis significa humilde, de baixa condição, alguém sem grande estatuto, pouco valor, desprezível. A ideia da humilhação traduz sempre uma ação de inferiorização de alguém em relação a outra pessoa.

Klein (1991) recorre a este sentido etimológico e define humilhação como uma experiência de alguma forma de ridículo, desprezo, desonra ou tratamento degradante por parte de outras pessoas. O autor utiliza o termo "Dinâmica da Humilhação" para se referir a este processo que, apesar de experimentado individualmente, é intrinsecamente social, localizado na relação entre a pessoa e o ambiente. Ele abarca tanto a experiência pessoal da humilhação quanto a dinâmica social que contém o potencial para sua eclosão.

Três papéis compõem este processo relacional. Além da vítima, que experimenta o desprezo, há o papel cumprido pelo humilhador, cuja atitude ou comportamento inflige a experiência humilhante, havendo também um ou mais espectadores que testemunham alguém sendo ridicularizado, tornado impotente ou degradado de alguma forma. Segundo Fernández, Saguy e Halperin (2015) e McCauley (2017), quando a humilhação é pública, ocorrendo na presença de mais testemunhas, sobretudo daquelas emocionalmente relevantes, a intensidade ou mesmo a qualidade desta experiência para as vítimas é afetada. Hartling e Luchetta (1999) apontam que embora o papel de vítima seja muito marcante para quem é alvo da humilhação, é provável que ela também tenha operado nos outros papéis em algum momento durante a vida.

Assim como Goffmann (2012) considera que na manipulação do estigma o papel dos normais e o papel dos estigmatizados são parte de um mesmo complexo, situada no campo da intersubjetividade, ainda que a humilhação seja uma experiência individual, suas particularidades só podem ser compreendidas dentro do contexto social, cultural e histórico em que as dinâmicas interpessoais ocorrem. Além dos papéis que atuam para a produção deste fenômeno social e apontadas anteriormente, Hartling e Luchetta (1999) e McCauley (2017) também destacam as relações de poder desigual, onde um humilhador, encorajado por sentimentos de poder encontra uma vítima que se sentirá impotente, paralisada, violada e condenada ao ostracismo. As testemunhas, por sua vez, sob a ameaça de situação semelhante, 
tentam escapar de serem futuros alvos, desenvolvendo o medo da humilhação. Isto faz com que os efeitos da humilhação sejam mais amplos do que apenas lidar com ela.

Os estudos de Klein $(1991,2004)$ também apontam que, independentemente de experiências anteriores, de ser uma vítima real da humilhação, sentir-se vulnerável a ela faz com que a pessoa desenvolva o desejo de evitá-la. Participar ou apenas observar a humilhação de outra pessoa seria suficiente para desencadear o medo de também estar sujeito à mesma situação e tentar escapar dela a todo custo. $\mathrm{O}$ medo da humilhação é tão importante quanto a sua vivência, podendo fazer com que um indivíduo atente contra a própria vida no desejo de evitar sua experimentação.

"Humilhação social é sofrimento longamente aturado e ruminado. É sofrimento ancestral e repetido" (Gonçalves Filho, 2007, p. 194). Esta "ruminação" é similar ao que foi abordado por Arregui (2009), ao tratar das consequências da humilhação em razão da estigmatização na vida do indivíduo. Como uma consequência cognitiva, muitas pessoas com deficiência descreveram que passaram muito tempo de suas vidas pensando obsessivamente sobre a sua condição e suas relações com os outros, geralmente marcadas por ostracismo, agressões e percepção de rejeição interpessoal. Outra consequência cognitiva estava relacionada à diminuição da sua motivação para o trabalho ou estudo devido à consciência da estigmatização social de sua condição física.

Os atos de humilhação e os sentimentos do humilhado também se relacionam às consequências comportamentais, que Arregui (2009) denomina como "não-comportamento", que consiste em evitar uma situação social em que o participante já antecipa que poderá sofrer estigmatização social, como por exemplo, "não se matricular na universidade para evitar a luta de ser aceito pelos outros, evitar ir a lugares públicos desconhecidos para não experimentar olhares e comentários de pessoas que não estão acostumadas a ver o participante" (Arregui, 2009, p. 66), como uma tentativa de evitar a humilhação a todo custo, como descreveu Klein (1991).

As consequências emocionais da estigmatização expressadas pelos participantes de sua pesquisa incluíam sentimentos de raiva, dor, desesperança provenientes da consciência da rejeição; medo e ansiedade sobre os contextos sociais nos quais elas estavam experimentando rejeição interpessoal; sentimento de humilhação, de que outras pessoas desvalorizavam suas características pessoais a ponto de desacreditar sua estima pelos outros. Outro comportamento identificado foi o desejo de omitir o sofrimento sentido em razão da rejeição interpessoal ou estigmatização pela crença de que uma intervenção dos adultos tornaria o problema maior. 
Nessa angústia represada, muito energia é utilizada para calar o sofrimento decorrente da situação de humilhação já concretizada e para evitar outras.

A energia dos servos é a energia todo tempo contrariada, acachapada, a energia que se contradiz. É a energia que o rebaixado precisa aplicar contra si mesmo, para não ouvir broncas ou ser castigado, para não sofrer e que, no entanto, traz amargura. A energia servil é o esforço de engolir (Gonçalves Filho, 2007, p. 216-217).

Desse repertório de consequências cognitivas, emocionais, comportamentais, pode-se deduzir que a estigmatização tem um potencial para produzir humilhação e marginalização do indivíduo em várias esferas da vida. Para evitar acumular mais experiências de humilhação e sofrimento, estas pessoas vão se retirando da vida social e profissional para viver no ostracismo, sendo relevantes fatores para pensar a frequência de pessoas com nanismo em espaços públicos, em comparação com pessoas com outras deficiências, e para pensar que realmente o nanismo é uma diferença diferente das demais deficiências, como sugerem Ablon (1990), Adelson (2005b, 2005c) e Kruse (2003).

Mas o caráter relacional da humilhação exige a expansão de sua análise para além do sentimento vivido por cada humilhado em sua individualidade. É necessário considerar a participação do outro, seja como pessoa, grupo ou instituição, na materialização desta experiência no contexto social. Em sua análise a respeito do conceito de humilhação, Piroli (2016) apresenta mais alguns elementos para pensá-la, apoiando-se em elementos trazidos por Avishai Margalit (1996), para explicar a humilhação institucional, Martha Nussbaum, que trata a humilhação como a face pública da vergonha social, e Axel Honneth, que traz a humilhação como rompimento de expectativas normativas de reconhecimento.

Em The Decent Society (A Sociedade Decente), Margalit (1996) apresenta o conceito de humilhação como um tipo de comportamento que fere o autorrespeito, entendido como respeito à própria humanidade. Para ele, agir de forma humilhante é tratar o outro como se não fosse humano, rebaixando-o à outra categoria, como objeto, máquina, animal, humano de segunda classe ou sub-humano, numa proporção que pode levar a sua humanidade a um estado de vulnerabilidade. Um tratamento humilhante fere a condição humana quando o respeito e a dignidade a ela associados são atacados, quando esta condição é inferiorizada e insuficiente em qualidades para considerá-la humana no sentido mais amplo.

Assim como Klein (1991), Margalit (1996) inclui o outro e a esfera relacional para considerar a humilhação. Utilizando uma definição normativa, Margalit (1996) recorre a uma concepção objetiva de humilhação baseada nas ações e omissões praticadas pelos indivíduos no convívio social e institucional, o que amplia o nível do sentido psicológico da humilhação. 
Para ele, o respeito pelos outros é a fonte necessária para a construção de uma relação normativa em relação a si mesmo. Kuch (2010) complementa dizendo que o autorrespeito e a autoestima, ainda que sejam sentimentos pautados por uma relação da pessoa consigo mesma, têm uma dimensão externa em que se dá a personificação e exibição no contexto social como orgulho e dignidade.

Para além de uma sociedade civilizada, em que os membros que compõem o seu corpo social não se humilham, Margalit (1996) aponta a necessidade de construção de sociedades baseadas na eliminação de qualquer forma de humilhação, denominada por ele de Sociedade Decente. Nela, são as instituições, tais como a família, Estado, escolas, que não humilham os indivíduos. Seus agentes, imbuídos de autoridade em decorrência do cargo, não impõem condutas humilhantes às pessoas que estão sob sua esfera de atuação.

Segundo Piroli (2016), Martha Nussbaum pauta a humilhação com base na condição de vulnerabilidade do indivíduo, reconhecidamente incompleto, necessitado uns dos outros, e que tem suas ações guiadas tanto pelo cálculo racional quanto pela mobilização de emoções. Entre elas está a vergonha, uma aversão à ideia de vulnerabilidade. Pessoas que desviam da norma, consideradas incompletas, imperfeitas ou indesejáveis, podem ser expostas à estigmatização no espaço público, onde eclode a vergonha. Como uma forma de zelar pela dignidade humana a nível social, Nussbaum (2004), assim como Margalit (1996), considera que as instituições devem proteger indivíduos e grupos da humilhação, propiciando um ambiente emocional saudável, em que prevalece o respeito mútuo.

Em Honneth (2003), o sentimento de dignidade e autorrespeito incorporado é resultado de uma relação intersubjetiva no mundo social onde se dá o reconhecimento. Eles pertencem à constituição da identidade social e pessoal (Honneth, 2003, Kuch, 2010). Inserida na dimensão das relações de solidariedade, a humilhação se dá quando o reconhecimento do outro como sujeito imputável, moral e juridicamente, é negado. Ao ser exposto publicamente como socialmente insignificante, sua autoestima e a do grupo ao qual se sente pertencente, é abalada, impedindo a totalidade de sua realização individual, ameaçando e ferindo sua identidade pessoal e social, prejudicando os relacionamentos intersubjetivos (Araújo Neto, 2013; Honneth, 2003; Piroli, 2016).

Estas formas de desrespeito, que compõem a base constitutiva da luta por reconhecimento, parecem reunir as asserções sobre humilhação de Margalit (1996) e Nussbaum (2004). A valorização do princípio da dignidade de todos os cidadãos e do direito à diferença enseja o engajamento num processo de interação social em que prosperam 
condições normativas de eticidade, onde o reconhecimento que vem do outro, entendido como indivíduo, grupo e instituição, é constitutivo para a formação das identidades individuais.

O estudo da humilhação ainda comporta sua diferenciação em relação à outras emoções a ela associadas, tais como vergonha, culpa, raiva e constrangimento. Facilmente confundidas, elas merecem aqui uma distinção, útil tanto para a prática psicológica quanto para política social, pois envolvem dinâmicas bastante diferentes ao nível individual e coletivo. Mais especificamente para esta pesquisa, demarcar estas diferenças favorece a identificação e análise do que foi comunicado pelos depoentes.

Hartling e Luchetta (1999), Klein (1991, 2004) e Neuhäuser (2010) consideram que, em comum, todas são caracterizadas por uma consciência e avaliação do eu. A humilhação e vergonha são as construções mais facilmente confundidas e as que compartilham mais características em comum. Ambas exigem a interpretação do indivíduo acerca do evento como vergonhoso ou humilhante e produzem um impacto sobre todo o eu, em vez de um aspecto do eu, com potencial para evocar respostas semelhantes dos indivíduos, tais como sentimento de exposição, irritação ou ansiedade. As consequências para o indivíduo podem ser temporárias ou duradouras. Na vergonha a ênfase se concentra num processo de reflexão e avaliação sobre si mesmo. O indivíduo não consegue viver em concordância com os ideais de comportamento considerado adequado aos próprios olhos e aos olhos dos outros. Essa forma de consciência pode cumprir uma função de adaptação apropriada o suficiente para protegê-lo de uma agressão ou exposição desnecessária, uma vez que o aspecto do comportamento causador da vergonha é passível de mudança. Na humilhação, a ênfase está na interação social, quando alguém é degradado ou forçado a uma posição degradada, sentindo-se ridicularizado, desprezado, não pelo que faz, mas pelo que é. Por isso, diferentemente da vergonha, ela não tem função adaptativa, pois as pessoas acreditam que não merecem a humilhação. Segundo Fernández, Saguy e Halperin (2015), a avaliação de ser vítima de uma injustiça é a variável-chave que diferencia a humilhação de outras associações, como vergonha e constrangimento.

Para Klein (1991, 2004), humilhação e vergonha não podem ser consideradas como semelhantes, embora a humilhação, às vezes, envolva o sentimento de vergonha e possa existir humilhação sem a vergonha. Não é preciso alguém ter vergonha de sua identidade para experimentar a humilhação de outras pessoas. Na prática, é possível alguém sentir humilhação sem sentir vergonha pelo comportamento ou identidade. Também é possível sentir vergonha por ato praticado sem sentir humilhação dos outros. Para reforçar a diferença entre elas, Gilbert (1997) e McCauley (2007) ressaltam que a humilhação requer um outro, um agressor, 
mas a vergonha não. Enquanto a vergonha é focada em si mesmo, a humilhação é focada nos danos causados pelos outros. Nussbaum (2004) aponta que, enquanto na vergonha o indivíduo assimila a visão da sua incompletude como um defeito, na humilhação alguém expõe publicamente o outro à vergonha, forçando-o publicamente a um estigma, uma identidade considerada vergonhosa.

Quanto ao constrangimento, Hartling e Luchetta (1999) afirmam que, por vezes, ele é considerado uma forma menor de humilhação, pois ambos decorrem de processos de interação. No entanto, o primeiro ocorre numa superfície da experiência pessoal, enquanto a humilhação atinge todo o eu, o senso de ser, sendo um ataque à identidade de uma pessoa. A culpa, por sua vez, está relacionada ao reconhecimento da violação de um padrão moral ou social pessoalmente relevante. Na raiva, diferentemente da humilhação, a desvalorização do self não é internalizada, como apontam Fernández, Saguy e Halperin (2015).

Insulto e humilhação também merecem diferenciação, como aponta Margalit (1996). Para ele, insultar alguém significaria diminuir a sua posição social, atacar a sua honra, enquanto humilhar significaria diminuir o seu autorrespeito, atacando a sua dignidade. Neuhäuser (2010) vê como problemática essa diferenciação, pois à luz da compreensão da humilhação, existem maneiras de diminuir ou atacar a honra social de alguém que não são apenas insultantes, mas humilhantes no sentido de violar a dignidade humana. Como exemplo, ser considerado um membro honrado de uma sociedade pode ser essencial para a construção do autorrespeito. Ao situar a dignidade de um lado e a honra social de outro, Margalit (1996) negligencia a dignidade social, que estaria entre estas duas e não se restringe apenas à honra. É este tipo de dignidade, social e não apenas humana, que permite a alguém ser considerado um membro plenamente respeitado em um tipo de sociedade. "A rejeição depende dos padrões desta sociedade particular e não da ideia fundamental de ser humano" (Neuhäuser, 2010, p. 32).

A definição do que é humilhação e para o que é experimentado como humilhante e degradante depende dos valores e crenças de cada sociedade, moldando a forma como cada uma lida com as diferenças e como contribuem para moldar a dimensão coletiva da humilhação (Klein, 2004). Neuhäuser (2010) utiliza o caminho da violação da dignidade humana ou "abordagem negativa da dignidade humana" para discutir a humilhação do grupo. Em consonância com a teoria de Axel Honneth, esta forma de desrespeito que atinge a todos em um grupo pode ser uma força propulsora para uma luta sociopolítica por reconhecimento.

Para o autor, há três maneiras diferentes de humilhar um grupo. No primeiro caso, chamado de humilhação direta do grupo, todos os seus membros, em uma determinada 
situação, poderão ser humilhados. Cada indivíduo é afetado individualmente e, neste caso, uma luta por reconhecimento deve concentrar-se ao nível do grupo. Como os grupos desempenham um papel significativo na vida de seus membros e são importantes para sua autodefinição, ferir um grupo equivale a prejudicar individualmente a autoimagem de cada um de seus membros. Neuhäuser (2010) oferece como exemplo deste tipo de humilhação o controle especial e degradante direcionado a muçulmanos em aeroportos, quando são estigmatizados como potenciais terroristas.

No segundo caso, chamado de humilhação simbólica, grupos inteiros de indivíduos podem ser humilhados pelos maus tratos a certos símbolos do grupo, ligando-se a uma ameaça real de rejeição da humanidade e não apenas uma forma de zombaria. Um exemplo seria a imagem de homossexuais na TV, que ainda não são tratados como iguais em nossas sociedades. As ameaças à sua dignidade, a rejeição da sua humanidade, não é apenas retratada, mas conectada a um perigo real.

No terceiro caso, chamado de humilhação do grupo representativo, todo um grupo é humilhado a partir da humilhação de um ou mais de seus membros, recebendo, de alguma forma, a sanção da sociedade. Aqui, as duas outras formas de humilhação anteriormente citadas, combinam-se. Individualmente, pessoas são humilhadas porque são membros de um grupo específico, ao tempo em que este nível de humilhação se constitui como uma humilhação simbólica do grupo.

Segundo Neuhäuser (2010), este último tipo de humilhação é o mais difícil de entender devido às dificuldades em se evidenciar de que modo a dignidade de um grupo pode ser violada pela humilhação de um ou alguns membros do grupo. Para o autor, é tentador conectar a humilhação coletiva à intenção não apenas de humilhar o indivíduo, mas todo o grupo. Embora as intenções desempenhem um papel, isso se dá mais ao nível psicológico e não normativo. Mesmo que a humilhação se dirija a uma parte coletivamente compartilhada da identidade também não há condição suficiente para estendê-la a todo o grupo. Esta parte precisa ser constitutiva do autorrespeito dos membros desse coletivo para que, não apenas o indivíduo se sinta violado, mas todo o grupo se considere insultado ou humilhado.

A humilhação de um membro do grupo é um insulto para todo o grupo quando existe um forte sentimento de um destino comum, de solidariedade, de conexão entre os membros do grupo que os levem à profunda simpatia entre si. Quando esta condição não se apresenta, a humilhação de um componente do grupo não gera nenhuma reação dos demais. Neuhäuser (2010) argumenta que todas estas explicações apenas justificam a presença ou ausência da 
sensação de ser insultado, mas não explica porque a humilhação dirigida a alguns membros de um grupo nem sempre é percebida como humilhante por todos os seus membros.

Para ele, a diferença está centrada nas atitudes sociais reativas ao que pode ser considerado humilhante. Um ato é humilhante para um grupo quando é sancionado no nível social, quando ninguém da sociedade a qual a pessoa pertence se importa com essa humilhação, não sendo tomadas medidas apropriadas contra ela. Com isso, a pessoa sente que sua identidade não é respeitada pela sociedade. Do contrário, quando a humilhação é perpetrada e há uma reação social adequada a ela, então não há razão para que ela se sinta humilhada. Mesmo que o autorrespeito não seja diminuído, pode até haver espaço para o sentimento de insulto se houver forte simpatia por quem foi insultado, uma vez que o ato de humilhação está intimamente ligado a uma identidade compartilhada. Segundo Neuhäuser (2010), “a humilhação de alguém que é tão parecido comigo poderia me dar uma razão para me sentir insultada em seu nome e em nome do que temos em comum” (p. 29).

Ainda segundo o autor, é no tipo de humilhação do grupo representativo que os argumentos para a luta por direitos de grupos específicos podem ser encontrados. A dignidade de toda pessoa humana é a base fundamental para os direitos humanos. Se é assim, todos os direitos básicos deveriam ser justificados com referência à dignidade individual, não sendo necessária qualquer interferência relativa a elementos culturais vigentes em cada sociedade. Desta forma, a honra social de nenhum de seus membros seria afetada. Mas como dito anteriormente, a rejeição depende dos padrões de cada sociedade, das condições sociais, e não da ideia fundamental de ser humano. E é a partir do conceito de dignidade social que se abre a possibilidade da reivindicação para direitos grupais, à igualdade de tratamento e reconhecimento, com políticas especiais que favorecem o cumprimento de direitos, como nas ações afirmativas.

Segundo Neuhäuser (2010), quando uma sociedade é confrontada com uma discriminação humilhante, ela torna-se visível quando se manifesta ao nível estrutural, ao nível do grupo dos que se sentem humilhados, e não ao nível individual. Por esta razão, quando grupos são humilhados e não tratados como iguais, sendo ameaçados em seu status de pertencimento ao todo social, eles têm direito a ações protetoras, como campanhas de conscientização. "Essas medidas são atitudes sociais reativas no contexto da humilhação grupal representativa” (Neuhäuser, 2010, p. 35). Os direitos de grupo são uma medida política adotada para impedir o tratamento humilhante dirigido a ele.

Como um ser humano como qualquer outro de sua categoria social (pessoas da mesma idade, sexo, profissão) e que merece uma vida com iguais oportunidades, pessoas com 
nanismo podem construir a percepção de que não são aceitos, estando suscetíveis a concordar que estão aquém das outras. Pessoas socialmente estigmatizadas frequentemente sofrem discriminação em esferas críticas da vida, tais como emprego, habitação, educação e interações sociais (Brascombe, Schmitt, \& Harvey, 1999; Gouvier, Sytsma-Jordan, \& Mayville, 2003). Segundo Stace e Danks (1981), adultos com displasias tem maiores dificuldades de encontrar emprego e casamento, sendo amplamente aceito que os déficits experimentados por crianças e adultos com baixa estatura são o resultado de fatores sociais e de respostas psicológicas e emocionais, em vez de complicações médicas.

As consequências de viver com este estigma se alargam principalmente na vida adulta, quando necessitam ampliar seus laços afetivos, sociais e profissionais. Os estigmas podem levar à discriminação nos empregos, designando um lugar de cada indivíduo na esfera do trabalho a partir da sua deficiência. É aí que muitos indivíduos estigmatizados se utilizam da sua desvantagem como base para organizar sua vida (Goffman, 2012). Eles acabam por adotar o lugar que a sua diferença lhe impõe na estrutura social, utilizando-se da identidade social de "anão", da carreira profissional disponível para o seu estigma, para fazer do uso de si, de sua imagem. As características do estigma são reproduzidas de forma profissional e eles assumem uma personagem cômica que se encaixa na moldura socialmente construída para ele, embora isso seja motivo de conflitos dentro do próprio grupo de estigmatizados.

Como aponta Goffman (2012), a vinculação do indivíduo com a sua categoria estigmatizada pode mostrar uma ambivalência de identidade. Mantendo ou não uma aliança com os seus pares, o indivíduo estigmatizado pode afastar-se quando vê que seus iguais comportam-se de um modo estereotipado, exibindo de forma desprezível ou extravagante os atributos negativos que lhes são imputados. Porém, sua identificação social e psicológica com o grupo o mantém unido a ele, transformando a repulsa em algo a se envergonhar. Outros, porém, podem recusar a aceitar o lugar social que lhes é destinado, repudiando trabalhos que implicam a manutenção e reprodução de uma identidade social estereotipada.

É partindo desse conflito travado dentro do próprio grupo de pessoas com nanismo no que diz respeito a trabalho que consideramos necessário acrescentar a esta pesquisa os estudos de Axel Honneth (2003) em "Luta por Reconhecimento". A interseção teórica entre sociologia do corpo, estigma e humilhação social se ajustam e se complementam na compreensão da formação do estigma e suas consequências no contexto da vida e qualidade das relações para a pessoa que vive com nanismo, partindo do ponto de vista do que "os outros", os "normais", constroem a respeito dela. Segundo Gonçalves Filho (1998), na humilhação social o oprimido internaliza o rebaixamento político como uma força traumática, 
ao mesmo tempo em que constitui a exclusão do homem para fora do reconhecimento intersubjetivo. "A exclusão que se internaliza, ela mesma irrompe as condições pelas quais o humilhado enfrentaria sua humilhação" (Gonçalves Filho, 1998, p. 44). Para Honneth (2003), as feridas morais, em ambiente político propício, podem se constituir como motivações para uma luta por reconhecimento. É o reconhecimento que estrutura a subjetividade e a identidade social e coletiva. Os conflitos que se originam de uma experiência de humilhação social, de um ataque à identidade social e coletiva, podem motivar uma ação que visa a restauração das relações de reconhecimento mútuo.

Os danos reais que este grupo populacional sofre pela imagem depreciativa e cômica que a sociedade lhes atribui provém de um contexto normativo que é base para as representações e práticas sociais. Sua pessoa inteira é posta à prova nas situações em que brincadeiras e comentários jocosos lhes são direcionados e quando sua visibilidade torna-se uma exposição quase que tirana de sua pessoa, ferindo sua dignidade e recusando-lhe o reconhecimento como pessoa em igualdade de direitos. Para Honneth (2003), os sujeitos lutam pelo reconhecimento recíproco de sua identidade para que tenham suas capacidades de autorrealização plenamente realizadas. Quando no quadro da divisão social do trabalho a consciência de que sua particularidade individual é obstáculo para a contratação em áreas comuns de emprego, então há o sentimento é de que o reconhecimento recíproco lhe é negado.

\subsection{O Reconhecimento em Axel Honneth}

A reunião de pessoas com nanismo em forma de organização não-governamental vem acontecendo no Brasil muito recentemente. Organizações deste tipo, como a Fundação Alpe de Acondroplasia na Espanha (ALPE), Little People of America (LPA) nos Estados Unidos, entre muitas outras em diversos países, serviram de inspiração para que no ano de 2014 fosse dada a largada para a criação de muitas associações em diversos Estados brasileiros, tais como a Associação de Nanismo do Estado do Rio de Janeiro (ANAERJ), Associação de Nanismo do Estado de São Paulo ( ANAESP), Acondroplasia - SC, Nanismo Capixaba, Somos Todos Gigantes, entre outras, de modo a reunir este grupo populacional e representar os seus interesses junto à sociedade e governos.

No caminho de outros grupos sociais que lutam pelo reconhecimento de suas demandas por inclusão na esfera pública, as pessoas com nanismo também têm se organizado 
sociopoliticamente para reclamar seus direitos em razão de necessidades inerentes à sua constituição identitária. A regulamentação do dia 25 de outubro como o Dia Nacional de Combate ao Preconceito contra as pessoas com nanismo através da Lei $\mathrm{n}^{\circ} 13.472$ (Brasil, 2017) é uma das conquistas que anuncia, no espaço público, a necessidade de reconhecimento de direitos como pessoas em igual valor na sociedade, o que vai além de uma questão de ordem econômica.

Por isso consideramos que a chave do "reconhecimento" precisa ser inserida na compreensão das consequências da estigmatização de pessoas com nanismo. Para isso, encontramos em Luta por Reconhecimento, de Axel Honneth (2003), pressupostos que explicam a estruturação da subjetividade e da identidade individual e coletiva em correlação com formas recíprocas de desrespeito. Para Mattos (2006), duas forças motrizes se dão na luta por reconhecimento: ao mesmo tempo em que há uma afirmação da diferença em uma sociedade na qual está prescrita a dignidade de todos os cidadãos pelo valor intrínseco de cada indivíduo, também se dá uma afirmação da diferença, uma vez que ela pede o reconhecimento da identidade específica de grupos. Para ela, igualdade de direitos e direito à diferença são dois princípios que devem andar juntos na esfera pública.

Honneth (2003) recupera os trabalhos de juventude de Hegel em Jena, para construir uma teoria social de caráter normativo. Para $\mathrm{Hegel}^{5}$, a base de todos os conflitos sociais é uma luta por reconhecimento e não uma luta por autopreservação, como preconizada Hobbes. Esta luta é o motor das mudanças sociais e leva à evolução da sociedade (Mattos, 2006). Permeando todas as relações, as obrigações intersubjetivas criam condições para a formação prática da identidade humana. Os conteúdos normativos presentes nos processos de interação passam a regular a ação de cada indivíduo, aumentando a dimensão prática de si mesmo.

Para Honneth (2003), o conceito de luta por reconhecimento de Hegel, apesar de conter os elementos básicos de uma teoria intersubjetiva da ordem social, ainda permanece atrelado a um viés idealista (Silva, 2010). Com a psicologia social de George Herbert Mead, ele encontra uma fundamentação empírica que lhe permite corrigir esse viés. Mead tinha como hipótese empírica de pesquisa que as pessoas devem sua identidade à experiência de um reconhecimento intersubjetivo. Ao se defrontar com um problema prático, o indivíduo é chamado a reelaborar a interpretação da situação. A eticidade intersubjetiva é convidada ao

\footnotetext{
${ }^{5}$ As citações de Hegel e Mead foram feitas a partir da leitura de Honneth, o que justificou não incluir as referências bibliográficas de cada autor.
} 
desenvolvimento da identidade quando o indivíduo é capaz de apreender sua própria ação na perspectiva do outro.

Com a apropriação crítica dessas duas teorias, coube à Honneth constituir uma teoria da sociedade de teor normativo que visa explicar "os processos de mudança social com base nas pretensões normativas estruturalmente inscritas na relação de reconhecimento recíproco" (Honneth, 2003, p. 155). O ponto de partida dessa teoria foi considerar que a reprodução da vida social ocorre baseada no reconhecimento recíproco. Os indivíduos só conseguem passar do conhecimento cognitivo para o prático quando são capazes de conceber a si mesmos como seres intersubjetivos num cenário onde há outros interesses concorrentes aos seus (Mattos, 2006).

Esse reconhecimento recíproco funciona como uma coerção normativa, o que obriga os indivíduos à "deslimitação gradual do conteúdo do reconhecimento recíproco" (Honneth, 2003, p. 156). Só por meio dele os indivíduos podem pretender expressar socialmente sua subjetividade. Assim, o processo de individuação está simultaneamente ligado à ampliação das relações de reconhecimento mútuo. Para se tornar uma teoria da sociedade, é preciso que estes processos estejam no interior da práxis da vida social.

Para Honneth (2003), a transformação normativa gerida pelas sociedades seria creditada às lutas moralmente motivadas de grupos sociais e sua tentativa de estabelecer, institucional e culturalmente, formas ampliadas de reconhecimento recíproco. Em vez de partir dos atos de sujeitos isolados, o que ele chama de categorias atomísticas, a teoria tem que considerar primeiramente o quadro em que os sujeitos se movem juntos desde o princípio por um vínculo social. Para uma autorrealização humana individual, é necessário que sejam respeitados os pressupostos normativos de uma ética universal que orientam as relações intersubjetivas. Caso não sejam, seus efeitos nocivos comprometem a formação do indivíduo e sua atuação de maneira autônoma.

A base natural da socialização humana se caracteriza pela existência de formas elementares de convívio intersubjetivo que se estabelecem primeiramente no vínculo entre pais e filhos, quando há reciprocidade entre os sujeitos como seres emocionalmente carentes; depois, o estado de "eticidade natural" passa para um estágio em que as relações éticas são liberadas de particularizações pelo reconhecimento das diferenças. Socialização e individuação, quando entrelaçadas, formariam uma sociedade organicamente coesa pelo reconhecimento intersubjetivo da particularidade de todos os indivíduos. As relações éticas de uma sociedade são formas de uma intersubjetividade prática que contam com a comunidade dos sujeitos contrapondo-se entre si para assegurar um movimento de reconhecimento, que 
amplia o conhecimento a respeito da identidade particular pela confirmação de uma nova dimensão de seu Eu pelo outro.

Além da necessidade do parceiro de interação na experiência prática, a família, o Estado e a sociedade também atuam como fatores de constituição da identidade. Partindo de Hegel e Mead, Honneth (2003) propõe uma tipologia fenomenológica para descrever três padrões de reconhecimento recíproco, aos quais correspondem etapas de autorrelação prática do ser humano. Na teoria da intersubjetividade, o reconhecimento que confirma os indivíduos como pessoas reciprocamente autônomas e individuadas, depende de três formas de reconhecimento: amor, direito e solidariedade. Esses padrões de reconhecimento intersubjetivo dariam um fundamento normativo a noções intuitivas de justiça, assim como de injustiça (Silva, 2010). Nelas é que residem as origens das tensões sociais e são geradas as motivações morais dos conflitos.

A primeira esfera do reconhecimento é o amor, que envolve todas as relações primárias e consistem em ligações emotivas fortes entre poucas pessoas. Podem ser relações eróticas entre dois parceiros, de amizades e de relações entre pais e filhos no interior da família. Satisfeitos ou correspondidos, o reconhecimento de carências e afetos são um encorajamento afetivo. Apoiando-se na psicanálise de Donald Winnicott, o autor analisa as relações entre mãe e filho, que vão da fusão completa à dependência relativa. No conflito intersubjetivo, um aprende com o outro a se diferenciarem e a tornarem-se autônomos. Ainda que dependentes, eles podem sobreviver sozinhos. Para Hegel, o amor é o cerne estrutural de toda eticidade, pois só uma ligação simbioticamente alimentada cria medida de autoconfiança individual, indispensável para a participação autônoma na vida pública. Para Honneth, em cada relação amorosa essa dinâmica conflitiva do jogo de dependência e autonomia se atualiza, dependendo dela o desenvolvimento primário da autoconfiança como base das relações sociais entre adultos (Honneth, 2003). O amor é a forma mais elementar de reconhecimento, o núcleo fundamental de toda moralidade, base do autorrespeito, da autonomia necessária para a participação na vida pública e condição para a o nível seguinte de reconhecimento.

Como apontam Rosenfield e Saavedra (2013, p. 6), na primeira fase do pensamento de Honneth, a esfera do reconhecimento do amor é tratada como uma esfera ontológica, subtraída do processo de mudança histórica. Mas na obra Redistribuição e Reconhecimento, em conjunto com Nancy Fraser, e em edições mais recentes de Luta por Reconhecimento, Honneth (2003) considera que também na esfera do amor pode ser encontrado um potencial normativo que é desenvolvido através de conflitos e lutas sociais. 
As relações de direito correspondem à segunda esfera do reconhecimento. Tanto Hegel quanto Mead perceberam que só podemos nos compreender como portadores de direitos quando temos o conhecimento sobre quais obrigações observar por causa do outro, atendendo a princípios morais universalistas na modernidade. Apenas da perspectiva normativa de um "outro generalizado", que nos ensina a reconhecer os demais membros da coletividade como portadores de direito, estaremos seguros do cumprimento social de algumas de nossas pretensões.

Honneth (2003) ressalta que, apesar desses pontos em comum, Hegel e Mead se diferenciam quanto à rede jurídica de reconhecimento. Hegel considerava que o reconhecimento do direito visa à constituição específica das relações jurídicas modernas, onde todos os homens, na qualidade de seres iguais e livres, seriam incorporados no direito positivo. Mead, por sua vez, estava interessado no "outro generalizado", ou seja, apenas na lógica do reconhecimento jurídico como tal. É importante esta distinção entre direito ligado à tradição e direito pós-tradicional porque deixa claro que, diferentemente daquela do amor, a forma de reciprocidade do reconhecimento jurídico foi se constituindo a partir de uma evolução histórica.

Para Honneth (2003), Mead só pôde atribuir ao reconhecimento jurídico um reduzido conteúdo normativo. "O que no sujeito individual alcança aqui reconhecimento de maneira intersubjetiva não é mais que sua qualidade legítima de membro de uma organização social definida pela divisão do trabalho" (p. 181). Tradicionalmente, essa forma de reconhecimento jurídico só concede ao sujeito uma proteção para a sua dignidade humana, pois ela ainda está completamente fundida com o papel social que lhe compete no quadro de uma distribuição de direitos e encargos amplamente desigual. Nas relações jurídicas ligadas à tradição, o reconhecimento como pessoa de direito ainda está fundido com a estima social que se aplica ao membro individual da sociedade, conforme o status que ele possui. Em razão disso, a classificação do reconhecimento jurídico é feita em graus, de acordo com a estima que o indivíduo goza como portador de um papel. Com a moral pós-convencional essa relação é dissolvida.

Em Hegel, a estrutura da qual pode derivar as determinações da pessoa de direito só assume a forma de reconhecimento do direito quando se adapta ao princípio de fundamentação universalista. Com a passagem para a modernidade, o sistema jurídico precisa ser entendido como a expressão dos interesses universalizáveis de todos os membros da sociedade, de modo a não mais admitir privilégios e gradações. 
Disso decorre que o respeito universalista não deve ser concebido como uma atitude ligada às emoções, mas somente como uma operação puramente cognitiva, que coloca barreiras às sensações afetivas. Na modernidade, os direitos já não dependem das expectativas construídas em torno de papéis sociais, competindo a todo homem a qualidade de ser livre. Há diferenças entre reconhecimento da pessoa da estima social por ela. Em ambos, um homem é respeitado em virtude de determinadas propriedades. No reconhecimento, ele é respeitado em razão da propriedade universal que faz dele uma pessoa. No caso da estima, são as propriedades que o diferenciam das outras pessoas que o tornam respeitado, ou não. Se para o reconhecimento jurídico é central saber como se determina a propriedade constitutiva da pessoa como tal, na estima social é necessário saber como o sistema referencial valorativo é constituído para que se possa medir o valor das propriedades que o caracterizam.

Nas primeiras décadas do século XX impôs-se definitivamente a convicção de que a todo membro de uma coletividade política deve caber o direito igual à participação no processo democrático de formação da vontade. A ampliação dos direitos individuais fundamentais, ligados ao bem-estar, à participação e liberdade, o status jurídico de cidadão individual, permitiram que os sujeitos encontrassem "reconhecimento jurídico não só na capacidade abstrata de orientar-se por normas morais, mas também na propriedade concreta de merecer o nível de vida necessário para isso" (Honneth, 2003, p. 193). No direito moderno, a consequência do princípio de igualdade foi a ampliação do status de uma pessoa de direito tanto no aspecto objetivo, que levou à acumulação de novas atribuições, mas também no aspecto social, sendo transmitido a um maior número de membros da sociedade.

Com a garantia de realização das liberdades individuais e a universalização da relação jurídica, que estendeu os mesmos direitos a todos os membros da sociedade, formaram-se as condições ideais para uma "luta por reconhecimento" no interior da esfera jurídica. O reconhecimento denegado ou o desrespeito são a origem dos conflitos em torno da ampliação do conteúdo material e alcance social do status de uma pessoa de direito.

Mediante a experiência do reconhecimento jurídico, a pessoa passa a se reconhecer como dotada de direitos, referindo-se a si mesmo como uma pessoa moralmente imputável e capaz de participar da vida social institucionalmente organizada e regulada, partilhando as propriedades para a participação em uma formação discursiva da vontade. Essas relações jurídicas geram o autor-respeito, uma "consciência de poder se respeitar a si próprio, porque ele merece o respeito de todos os outros" (Honneth, 2003, p. 195).

Para não ter uma autorrelação violada, Honneth (2003) afirma que "além da experiência da dedicação afetiva e do reconhecimento jurídico, os sujeitos precisam da estima 
social que lhes permita referir-se positivamente às suas propriedades e capacidades concretas" (p.198), o que corresponde à terceira forma de reconhecimento, a saber, a Comunidade de Valores ou Solidariedade.No nível social, essa operação é mediada pelas orientações simbólicas que constituem a autocompreensão cultural de uma sociedade. Valores e objetivos éticos aí presentes podem servir de referência para a avaliação de determinação do valor social de propriedades da personalidade dispostas a contribuir com objetivos sociais predeterminados.

A autocompreensão cultural de uma sociedade predetermina os critérios pelos quais se orienta a estima social das pessoas, já que suas capacidades e realizações são julgadas intersubjetivamente, conforme a medida em que cooperaram na implementação de valores culturalmente definidos (Honneth, 2003, p. 200).

Esta forma de reconhecimento está ligada a um contexto de vida social em que os objetivos e valores funcionam como referência para a avaliação moral das propriedades pessoais dos seres humanos e cuja totalidade constitui a autocompreensão cultural de uma sociedade (Rosenfield \& Saavedra, 2013). Se as concepções éticas predominantes na sociedade determinam a estima social, então elas são variáveis historicamente, como ocorre no reconhecimento jurídico. Quanto mais as concepções dos objetivos éticos contemplam a pluralização de valores socialmente definidos, maior o traço individualizante da estima social e a possibilidade de criar relações simétricas. Para Honneth (2003), sob as condições das sociedades modernas, a solidariedade tem como pressuposto relações sociais de estima simétrica entre sujeitos individualizados e autônomos. Essas relações podem ser chamadas de solidárias porque despertam tolerância e o interesse para com a particularidade de cada pessoa.

Rosenfield e Saavedra (2013) destacam que esta terceira esfera de reconhecimento denominada por Honneth de Solidariedade recebe outra denominação em sua obra publicada posteriormente, em conjunto com Nancy Fraser, denominada Redistribution or Recognition? (Redistribuição ou Reconhecimento?). Lá, ele utiliza o princípio do Rendimento (Leistung), o que abre caminho para uma análise mais recente sobre reconhecimento e trabalho.

Assim, como na relação jurídica, a estima social também passou por transformações ao longo da história. Para assumir a forma atual, sua história conceitual transitou pelos conceitos de honra, categorias de "reputação" ou "prestígio" social. A reputação de uma pessoa era definida a partir da honra social, obtida através da sua contribuição para a realização de valores centrais de sua coletividade em obediência à estratificação vertical no 
campo das tarefas sociais. A obediência às formas específicas de conduta de vida fazia com que o indivíduo alcance a honra apropriada a seu estamento. O termo honra era uma medida de reputação social que uma pessoa é capaz de adquirir quando consegue cumprir expectativas coletivas de comportamento, eticamente atreladas ao status social.

Dentro dos grupos determinados por status, os sujeitos poderiam se estimar um ao outro, já que partilhavam capacidades e propriedades que recebem uma reputação social na escola dos valores sociais pela situação social comum. As relações de estima eram escalonadas numa hierarquia que permitia aos membros estranhos ao estamento estimarem as propriedades e capacidades de um sujeito, como uma medida culturalmente predeterminada. Com a passagem para a modernidade, começaram os questionamentos a respeito da medida da reputação de uma pessoa ser realizada pelo valor previamente determinado de propriedades atribuídas a grupos inteiros, tipificando-os. A partir de então, o sujeito, como uma grandeza biograficamente individuada, disputa o campo da estima social.

Estas mudanças levaram à transformação dos princípios de honra, escalonados segundo o estamento, a migrarem para a relação jurídica reformada, onde alcança validade universal com o conceito de "dignidade humana". Mas esta relação jurídica não abarca todas as dimensões da estima social. Para a pessoa se sentir valiosa para a sociedade, ela precisa ser reconhecida em capacidades e propriedades que a torna distinta das demais pessoas. A dissolução da hierarquia tradicional leva à individualização na representação de quem contribui para a realização das finalidades éticas. A estima social passa a ser orientada não mais pelas propriedades coletivas que estabeleciam as formas de conduta eticamente admissíveis, mas sim pelas capacidades que o próprio indivíduo desenvolveu. "O contexto de honra social vai se adelgaçando gradativamente, até tornar-se o conceito de prestígio social" (Honneth, 2003, p. 205).

O uso da categoria "honra" começou a declinar, ficando seu uso restrito à esfera privada como critério subjetivo de avaliação da própria autocompreensão, dignos de defesa incondicional. O conceito de honra passa a ser preenchido pelas categorias "reputação" ou "prestígio", com as quais se deve apreender a estima que o indivíduo goza socialmente. Honneth (2003) alerta que esse novo padrão de organização do reconhecimento estreitou a camada do valor de uma pessoa. A universalização jurídica da honra até tornar-se dignidade, e a privatização da honra até tornar-se integridade, definida subjetivamente, fez com que a estima social não pudesse mais estar associada nem a privilégios jurídicos, nem à caracterização de qualidades morais da personalidade. O prestígio ou a reputação estão restritos apenas ao reconhecimento social que o indivíduo merece por contribuir com a 
implementação prática dos objetivos da sociedade. A nova ordem individualizada do reconhecimento passa a ser dependente de um horizonte universal de valores plurais que contemple formas distintas de autorrealização.

Na prática, esse sistema referencial universal de determinação de finalidades sociais não é válido porque, para ser concretizado, precisa passar pelo crivo de interpretações culturais aplicáveis à esfera do reconhecimento. O conteúdo de cada interpretação depende de como cada grupo social interpreta como valiosa as próprias realizações e formas de vida. Por isso, Honneth (2003) afirma que:

nas sociedades modernas, as relações de estima social estão sujeitas a uma luta permanente na qual os diversos grupos procuram elevar, com os meios da força simbólica e em referência às finalidades gerais, o valor das capacidades associadas à sua forma de vida. Contudo, o que decide sobre o desfecho dessas lutas, estabilizado apenas temporariamente, não é apenas o poder de dispor dos meios da força simbólica, específico de determinados grupos, mas também o clima, dificilmente influenciável, das atenções públicas (p. 207).

Por esta razão, os movimentos sociais precisam chamar a atenção da esfera pública para a negligência com que são tratadas as capacidades e propriedades dos membros de cada coletivo, esperando, com isso, elevar o valor social e a reputação de seus membros. Os estamentos que organizam a forma de reconhecimento da estima tornam a experiência de distinção social correspondente restrita somente à identidade coletiva do próprio grupo, deixando em segundo plano o valor social que o sujeito individuado poderia obter. Neste modelo estamental, o destino da estima social é direcionado às propriedades coletivas tipificadas de seu estamento, ao grupo em sua totalidade, e não a ele individualmente. Daí resulta que o indivíduo chega a uma autorrelação prática de orgulho do grupo ou de honra coletiva. Nas relações internas de tais grupos, as formas de interação se caracterizam por relações solidárias, porque todo membro se sabe igualmente estimado em relação aos outros. Solidariedade pode, então, ser entendida como uma relação interativa em que os sujeitos, que se estimam simetricamente, se interessam mutuamente por seus modos distintos de vida.

Com a individualização do reconhecimento da estima, modifica-se também a relação prática consigo próprio. O respeito gozado por um indivíduo não é mais atribuído ao grupo ao qual pertence, de modo que todos possam gozar socialmente dele. A experiência pessoal da estima social é vivenciada pelo indivíduo com uma confiança emotiva na apresentação de realizações ou na posse de capacidades que são reconhecidas como valiosas pelos demais 
membros da sociedade. Essa autorrelação prática também é conhecida como autoestima, sentimento do valor próprio, autoconfiança e autorrespeito.

Estas esferas de reconhecimento tratadas por Honneth (2003) ajudam a pensar a problemática da inserção no mercado de trabalho de um grupo populacional sob o qual pesa uma interpretação cultural e, consequentemente, um sistema valorativo baseado em orientações simbólicas do passado. A medida de reputação de todas as pessoas com nanismo é atingida pela tipificação atribuída à identidade coletiva de "anão". Sob o princípio da dignidade, não basta ser reconhecido como possuidor de direitos, já que estes não poderão ser gozados em toda a sua extensão se disso depende o respeito à sua dignidade no campo da estima, o respeito à sua posição na esfera pública. Sendo negado, o indivíduo pode ser rebaixado em sua dignidade, o que abre a possibilidade para humilhação social, como discutido anteriormente.

Para cada forma de reconhecimento - amor, direito, solidariedade - há uma autorrelação prática do sujeito - autoconfiança nas relações amorosas e de amizade, autorrespeito nas relações jurídicas e autoestima na comunidade social de valores. É a ruptura dessas autorrelações pelo reconhecimento denegado que deflagram os conflitos sociais em que os indivíduos, não reconhecidos, sentem-se desrespeitados. A integridade do ser humano, segundo Honneth (2003), se deve a esses padrões de reconhecimento pois:

$\mathrm{Na}$ autodescrição dos que se veem maltratados por outros, desempenham até hoje um papel dominante categorias morais que, como as de "ofensa" ou de "rebaixamento", se referem a formas de desrespeito, ou seja, às formas de reconhecimento recusado (p. 213).

Para ele, esses conceitos negativos representam uma injustiça não apenas porque dificulta a liberdade de ação dos sujeitos, mas também porque lhes inflige danos à compreensão positiva de si mesmas. Se uma autoimagem normativa de cada ser humano depende da possibilidade de reconhecimento do outro, então a experiência de desrespeito abre condições para desmoronamento da identidade da pessoa inteira.

As expressões "desrespeito" ou "ofensa" podem incluir muitas formas de rebaixamento palpável decorrente da denegação de direitos básicos elementares e a humilhação sutil que acompanha a menção púbica ao insucesso de uma pessoa. As próprias graduações no conceito de reconhecimento já indicam as diferenças internas existentes entre algumas formas de desrespeito. Se a experiência de desrespeito é sintoma de um reconhecimento recusado, negado, então, a diferenciação dos três padrões de reconhecimento orientam a distinção de outros tantos modos de desrespeito. As diferenças devem se medir 
pelo dano causado à autorrelação prática de uma pessoa, comprometendo suas pretensões de identidade. O próprio Honneth (2003) lança a pergunta:

como a experiência de desrespeito está ancorada nas vivências afetivas dos sujeitos humanos, de modo que possa dar, no plano motivacional, o impulso para a resistência social e para o conflito, mais precisamente, para uma luta por reconhecimento? (p. 214).

Para ele, esta resposta não foi dada nem por Hegel e nem por Mead. Para buscar respostas, Honneth (2003) se apoiou nos pilares do reconhecimento, amor, direito e solidariedade, de forma a estabelecer as diferenciações. Com base na tipologia que estrutura as relações de reconhecimento em primárias, jurídicas e de comunidade de valor, Honneth (2003) aponta um equivalente correspondente de negação do respeito.

Partindo da esfera de reconhecimento do amor, ele trata do desrespeito como maus tratos e violação. Para Honneth (2003), é um desrespeito que toca a camada da integridade corporal de uma pessoa, numa tentativa de se apoderar do seu corpo, contra a sua vontade, seja qual for a intenção, tirando de forma violenta todas as possibilidades de livre disposição de seu corpo. Para ele, é a espécie mais elementar de rebaixamento pessoal que provoca um grau de humilhação que interfere destrutivamente na autorrelação prática de um ser humano, com mais profundidade do que outras formas de desrespeito porque não abrange apenas a dor corporal da tortura, violação, mas porque está ligada com o sentimento de estar sujeito à vontade de uma outra pessoa, sem proteção. Para Rosenfield e Saavedra (2013, p. 23), o componente da personalidade que é atacado é aquele da integridade psíquica, ou seja, não é diretamente a integridade física que é violentada, mas sim o autorrespeito que cada pessoa possui de seu corpo, adquirido por meio do processo intersubjetivo de socialização pela dedicação afetiva. Se o indivíduo teve sua autoconfiança adquirida na socialização com base na dedicação emotiva, este desrespeito terá como consequência a perda da confiança em si e no mundo, estendendo-se até abalar as camadas corporais de relacionamento prático com outros sujeitos, como um tipo de vergonha social, rompendo uma integração bem sucedida entre as qualidades corporais e psíquicas que geram colapso na fidedignidade do mundo social e na própria autossegurança que não se limitam a um tempo histórico ou ao quadro cultural de referência, embora existam sistemas de legitimação que procurem justifica-la socialmente.

À forma de reconhecimento do direito, corresponde o desrespeito intitulado privação de direitos. Neste caso, o componente da personalidade ameaçado é o da integridade social. Está relacionada a experiências de rebaixamento que afetam seu autorrespeito moral. Formas de desrespeito são infligidas a um sujeito pelo fato dele permanecer estruturalmente excluído da posse de determinados direitos na sociedade. Se todos são membros em igual valor na 
sociedade e a eles garantidos direitos para legitimar suas pretensões individuais, a denegação de direitos a alguns de seus membros impõe ao sujeito o sentimento de não possuir o status de igualdade. A privação violenta da autonomia pessoaltraz a constatação de que o indivíduo não possui status de um parceiro de igual valor e moralidade. A denegação das pretensões jurídicas socialmente vigentes significa ser lesado na expectativa intersubjetiva do reconhecimento de sua capacidade de formar juízo moral, levando à experiência de perda de autorrespeito, ou seja, "uma perda da capacidade de se referir a si mesmo como parceiro em pé de igualdade na interação com todos os próximos" (Honneth, 2003, p. 217).

Finalmente, a negação da solidariedade corresponde à forma de desrespeito da degradação moral e da injúria, que ameaça a dignidade. Honneth (2003) afirma que só com essas formas avaliadoras de desrespeito, de desprezo de modos de vida individuais ou coletivos, que se atingiu a forma de comportamento hoje conhecida por "ofensa" ou "degradação". Honra, dignidade, status, são medidas de valoração social concedidas na tradição cultural de uma sociedade ao seu modo de autorrealização. Se esta hierarquia de valor social for constituída de modo a degradar formas de vida individuais julgadas inferiores ou deficientes, ela irá retirar dos sujeitos atingidos qualquer possibilidade de atribuírem um valor social às próprias capacidades. A recusa em reconhecimento se traduz em negação da aprovação social, o que conduz à perda da autoestima pessoal.

É especialmente nas esferas do direito e da solidariedade que estão mais intensamente incorporadas as dimensões ligadas ao trabalho, quando a rotina comum da maioria das pessoas que seguem diariamente para o trabalho, como uma etapa natural da vida, pode começar a suscitar nas pessoas com nanismo um questionamento sobre o direito àquele modo de vida pra si. Teriam direitos iguais realmente concedidos no mercado de trabalho? Suas capacidades para o trabalho poderiam ser valorizadas e reconhecidas? Para possuir a dignidade do reconhecimento prometido pela sociedade, é preciso que haja uma conexão entre o trabalho organizado e estruturado e as exigências de reconhecimento estabelecidas, sob o risco de as pessoas experimentarem as condições sociais dadas em termos morais como danos ou exclusões não justificadas (Honneth, 2009).

Adiante, nos detemos mais especificamente na discussão a respeito do reconhecimento na esfera do trabalho. 


\subsection{Trabalho e reconhecimento}

As transformações ocorridas no mundo do trabalho nos últimos anos, tais como a reestruturação produtiva, competitividade, flexibilidade das relações contratuais de trabalho, diversificação de alternativas de trabalho, precarização dos empregos, inserção tecnológica no contexto produtivo, entre outros fenômenos, tem gerado impacto não apenas no cotidiano do trabalhador dentro das organizações (Antunes, 2015). Estas mudanças nas condições objetivas do trabalho também modificaram as relações sociais nos locais de trabalho, sendo determinantes para a produção de subjetividades, produção de significações em relação a ele e influenciando também na dinâmica da constituição de processos identitários (Furtado, 2004). Como ressalta Coutinho (2009), embora tais discussões tentem abarcar as formas de ser dos sujeitos incluídos/excluídos no atual contexto produtivo, geralmente tomam como referência grupos de trabalhadores majoritários, demandados pelas organizações por suas habilidades, nível de escolaridade e graus de especialização mais altos, ou seja, trabalhadores cuja força de trabalho é competitiva.

A política de inclusão tomando como via o trabalho tem sido exitôsa em garantir o acesso de pessoas com deficiência a este direito. Segundo a OIT (2015), o trabalho é uma poderosa via de inclusão social porque permite que os benefícios do desenvolvimento possam chegar às pessoas, alterando suas condições de vida. Por meio dele, as pessoas não tiram apenas os seus salários, mas toda uma gama de outras vantagens indiretas, como status social decorrente da posição no mercado de trabalho (Guimarães, 2009).

Para Barnes e Mercer (2005), algumas abordagens traçam uma linha clara entre cidadania e exclusão (definida como uma negação ou não realização dos direitos políticos, civis e sociais de cidadania), o que tem ressonância principalmente entre as pessoas com deficiência porque presume inclusão nos sistemas de direitos. Em outras formulações, cidadania é associada a um agente econômico, tendo como pressuposto privilegiar o vínculo de um emprego remunerado a outras formas de atividade de trabalho. Por isso o trabalho cumpre papel preponderante para a redução da pobreza e das desigualdades sociais. A alta taxa de pobreza é o maior problema entre as pessoas com deficiência e baixas taxas de emprego contribuem para aumentar a probabilidade de pobreza (Ali, Schur, \& Blanck, 2011; Organização para a Cooperação e Desenvolvimento Económico [OECD], 2011; Schur, Colella, \& Adya, 2016). Todavia, um emprego é importante não apenas pelo lado econômico, mas também pelos seus efeitos psicológicos e sociais. 
Hartmann e Honneth (2009) assinalam que na Era social-democrata, a ordem jurídica moderna realizou notáveis avanços normativos ao eliminar muitas formas de discriminações legais que proibiam, sancionavam ou declaravam tabu as práticas de minorias culturais e sexuais. Ao mesmo tempo, em muitas áreas foram expandidos direitos de liberdade e sociais (laboral, penal, familiar) e direitos subjetivos, melhorando as bases econômicas e sociais para o desenvolvimento individual da autonomia e promovendo a generalização da igualdade jurídica que permitiram a certos grupos de excluídos gozar de direitos de cidadão pela primeira vez. Através de uma política social e econômica reguladora por parte do Estado, é possível impor institucionalmente avanços que favoreçam normas de reconhecimento de integrantes da sociedade antes alijados do processo de inserção profissional.

Nas relações jurídicas brasileiras, a Lei que garante a reserva de vagas para pessoas com deficiência em empresas abriu o caminho para a inserção no mercado de trabalho formal. Como ação afirmativa, essa medida jurídica criou condições e instrumentos para oferecer oportunidades iguais aos desiguais por meio de políticas de acesso ao emprego para grupos populacionais mais expostos à vulnerabilidade, como as pessoas com deficiência. Os dados de inserção no mercado formal de trabalho demonstram que tem sido exitosa essa política. Segundo o Departamento Intersindical de Estatística e Estudos Socioeconômicos [DIEESE] (2016) e a RAIS (2014), nos últimos anos o número de empregos formais para pessoas com deficiência, de todos os tipos, aumentou. Totalizaram 403.255 empregos formais no ano de 2015. Entre os tipos de deficiência, são as pessoas com deficiência física que ocupam o maior número de empregos com contratos de trabalho celetista concentrados, em sua maior parte, na região Sudeste do Brasil (DIEESE, 2016). Apesar do expressivo aumento de empregos formais desde a Lei de Cotas, ele representa menos de $1 \%$ do total da força de trabalho, quando a população com deficiência no país chega a 23,9\% (Cartilha do Censo, 2012).

Como não há dados sobre a inserção no trabalho de pessoas com nanismo, há de se considerar que fatores específicos podem interferir em sua dinâmica das relações de trabalho. Não sendo possível livrar-se do estigma e nem descontruir anteriormente à contratação o imaginário social a seu respeito, elas ficam sujeitas a pressupostos morais e normativos que dirigem as escolhas e as relações de trabalho no mercado. Ainda que este pano de fundo também esteja amplamente presente em outras contratações, para estas pessoas são arbitrados fatores de diferenciação que colocam em suspeição o valor real de suas contribuições laborais. As relações aí estabelecidas recebem o peso do estigma social que marca este segmento populacional. 
Como se já não fosse difícil ultrapassar obstáculos colocados na via de acesso ao emprego, também no trabalho age a discriminação negativa. Como afirma Castel (2011, p. 47), "ela pode poluir as relações entre trabalhadores e bloquear as carreiras profissionais". A recusa do reconhecimento limita a autonomia pessoal e profissional pelos lugares que a exploração produtiva reserva para a valorização de sua identidade. Por isso consideramos necessário continuar pensando a categoria trabalho a partir do reconhecimento. Como assinala Visser (2018), a categoria trabalho é uma força para a teoria do reconhecimento por ser um dos “pilares da fundamentação normativa de um corpo social” (p. 357).

A partir da explicitação de uma experiência intersubjetivamente compartilhada (saber adquirido no conflito), o conceito de reconhecimento pressupõe, acertadamente, que as ações, emoções e ponderações dos agentes tomem sempre o outro como referência. Por outro lado, o aspecto central da categoria de reconhecimento é sua alusão a certa simetria, paridade e reciprocidade em interações sociais. Ao reconhecer outrem como sujeito, confere-se um estatuto de humanidade a alguém ("ser alguém"), proporcionando-lhe a possibilidade de constituir autoestima e autorrelação prática positiva consigo (Visser, p. 357).

Para Honneth (2007), se nas sociedades tradicionais o respeito jurídico e a estima social estavam amalgamados ao conceito de honra e eram legitimados pelo pertencimento a um estrato social, nas sociedades capitalistas a reorganização do status jurídico e da ordem de prestígio decompôs a honra em duas ideias opostas. A parte assegurada pela hierarquia foi, de certa forma, democratizada, pois todos os membros da sociedade foram juridicamente considerados iguais em dignidade. Quanto à outra parte, caberia à cada cidadão produtivo desfrutar de estima social conforme seu mérito. Como assinala Silva (2010, p. 12), "essa diferenciação abriu o caminho para a emergência do mérito individual como ideia cultural proeminente". Se a solidariedade era a forma apropriada de reconhecimento na obra Luta por Reconhecimento, em Redistribuição ou Reconhecimento? é o mérito individual que passa a ser a base para a estima social. É principalmente da ideia cultural que provém a estigmatização da pessoa com nanismo.

Somados todos os fatores que caracterizam a vida desse grupo em estudo, seja no âmbito individual e coletivo, a estas pessoas fica atribuída a difícil tarefa de tentar desenraizar-se desta moldura que lhes foi atribuída para ingressar numa arena de competição por trabalho onde prevalecem medidas de desempenho e produtividade, valoração de competências intelectuais e aspectos subjetivos que atribuem valor às pessoas. Como aponta Honneth (2008, p. 5), "no âmbito da esfera econômica, as atividades desenvolvidas individualmente estão sujeitas a exigências especiais que resultam da necessidade de sua 
efetivação na troca social de realizações". Obrigações e condições são colocados na esfera de produção socialmente organizada.

Quando no campo social a desigualdade se manifesta pela discriminação, sublinhada pela diferença que deflagra a suspeição e rejeição (Castel, 2011), são colocados obstáculos à igualdade de chances e negado um direito fundamental para o exercício da cidadania, comprometendo o sentimento de pertinência social. Na vida adulta, a necessidade de manutenção econômica se individualiza e é por meio do trabalho que os rendimentos para isso podem ser auferidos. A necessidade material é fundamental, mas a questão do trabalho também mobiliza subjetividades implicadas em sua atividade, engendrando processos do psíquico e do social em sua análise (Furtado, 2004). Para Lhuilier (2013), ao agir sobre o seu ambiente, esta ação põe em jogo as razões e até possibilidades de existir de cada um.

E é assim que Honneth (2008) não minimiza o lugar que o trabalho assume no mundo socialmente vivido, tendo em vista que a identidade da maioria da população deriva do papel desempenhado no processo organizado de trabalho. Nem mesmo no sentido normativo se pode alegar a perda de importância do trabalho, pois "o desemprego segue sendo experimentado como um estigma social e como mácula individual, relações precárias de trabalho são percebidas como fardos" (p. 47). Sua análise também não se detém apenas à sua função imediatamente econômica, já que as pessoas também continuam buscando um trabalho gerador de satisfação individual. Para ele, "visualizar o mercado capitalista sob a perspectiva funcionalista do incremento da eficiência econômica" (Honneth, 2008, p. 54) é estar sob o risco de análise superficial de regras que estruturam a moderna organização capitalista do trabalho.

Partindo da "forma real de organização do trabalho" (p. 54), a análise deste mercado precisa incluir o cumprimento da função da integração social, o que coloca no panorama uma série de normas morais que se vinculam ao moderno mundo do trabalho, obrigando as instituições políticas e sociais a se esforçarem constantemente a se adaptarem às modificações das estruturas econômicas (Hartmann \& Honneth, 2009). Desta forma, ele estabelece uma base normativa da atual organização do trabalho para fazer uma crítica imanente das relações reais de trabalho, que seja operada a partir de parâmetros normativos inerentes à própria troca de realizações.

Honneth (2008) busca na Filosofia do Direito de Hegel, e em Durkheim, o repertório de princípios morais do mundo do trabalho. Na terminologia do reconhecimento, cunhada por Hegel, já se faziam presentes os elementos de uma forma de integração social nas estruturas da organização capitalista em processo de formação. Para este, o sistema de relação de troca 
mediado pelo mercado precisa satisfazer condições normativas para não ficar sem a legitimação moral que ancore a produtividade no agir econômico. Como seres privados, o egoísmo subjetivo do indivíduo seria transformado na disposição individual de cada um atuar para a satisfação das necessidades de todos os outros, construindo assim, um sistema de dependência recíproca que assegure a subsistência econômica de todos. A ameaça às condições normativas de reconhecimento poderia advir da acumulação de riquezas nas mãos de poucos, ocasionada pela falta de regulação da produção de bens orientada ao lucro, o que deixaria grande parte da população sem trabalho e, consequentemente, em situação de dependência de miséria. Manter estas pessoas, que ele denomina de "plebe", com gastos beneficentes dos ricos, faria com que a subsistência dos necessitados ficasse desatrelada do trabalho, o que é contrário ao sentimento de autonomia e honra da sociedade burguesa.

Nas convicções de Hegel, aponta Honneth (2008), as estruturas do mercado capitalista de trabalho se formaram sob condições morais que prometiam garantir às camadas sociais não apenas a expectativa de uma remuneração pelas atividades exercidas, suficiente para lhes garantir a subsistência, mas tambémum trabalho digno de reconhecimento. Esses pressupostos, de fato, tiveram pouca influência sobre o desenvolvimento econômico, embora permaneçam válidos. Nas palavras de Honneth (2008, p. 59):

os acontecimentos no mercado do trabalho, amplamente intransparente, se realizam sob pressupostos de normas morais que permanecem válidas mesmo quando o desenvolvimento histórico as transgride. Ao mesmo tempo, estas certezas normativas de fundo formam o recurso moral ao qual os atores podem recorrer quando quiserem questionar as regulamentações existentes na organização capitalista do trabalho.

Mais uma vez, encontra-se aí também uma fundamentação para a luta moral de movimentos sociais que reivindicam reconhecimento também na esfera do trabalho. Mesmo que as exigências normativas propostas por Hegel não tenham sido suficientes para prevenir os males vindouros na regulação do mercado capitalista de trabalho, elas foram fundamentais para refletir sobre o padrão de aproveitamento capitalista do trabalho.

Após oitenta anos, é Emile Durkheim, em sua obra Da divisão do trabalho social, quem retoma a tentativa de compreender a demanda de um trabalho dotado de sentido. Segundo Honneth (2018), ele levanta a questão sobre a capacidade da sociedade moderna de desenvolver, entre seus membros, um sentimento de solidariedade, de pertinência social perante a crescente divisão do trabalho cada vez mais organizada em forma de mercado. Assim como Hegel, Durkheim sustenta a convicção de que a eficiência econômica e o crescimento não são suficientes para a legitimação moral de uma economia que pretenda 
integração social. Para ele, é preciso buscar na realidade econômica as condições para uma consciência embasada na pertinência social e não na tradição moral ou religiosa.

O que para Hegel é reconhecimento, Durkheim denomina como solidariedade orgânica as relações de reconhecimento recíproco de seres que se sabem interdependentes em suas contribuições na divisão do trabalho mediada pelo mercado. Se para Hegel é uma renda suficiente para a subsistência que garante a autonomia e a integração social, para Durkheim são a equidade e transparência da divisão social do trabalho nas relações de troca do mercado de trabalho que devem cumprir esta função. Primeiro, é preciso garantir iguais condições de partida na aquisição de qualificações, seguido pela remuneração de todas as contribuições sociais segundo seu valor real para a comunidade. Segundo, é preciso que as atividades individuais estejam relacionadas umas às outras de modo transparente, como um esforço comum em um contexto cooperativo para o bem geral. Para tornar isso possível, as etapas do trabalho precisariam ser complexas e exigentes a ponto do indivíduo ser capaz de relacionálas com os demais trabalhos, dotando de sentido aquilo que faz. Para Honneth (2018), ficaram plantadas nas proposições de Durkheim as reivindicações de uma experiência de trabalho significativo.

Se estas ideias do passado propunham dotar o mercado de trabalho capitalista de uma infraestrutura moral suficiente para a integração social, hoje elas encontram restrição cada vez maior diante das condições estruturais gerada pelo sistema de aproveitamento capitalista do trabalho. Para Hartmann e Honneth (2009, p. 390),

as ideias orientadoras normativas das décadas passadas bem seguem tendo uma atualidade performativa, mas de maneira sublimal parecem haver perdido ou transformado seu significado emancipador, já que em muitas partes se tem convertido em conceitos meramente legitimadores de um novo nível de expansão capitalista.

Para eles, o capitalismo é capaz de atualizar justificativas de desigualdade, injustiça ou prejuízo social. Por isso, é um engano supor que as desigualdades ligadas aos padrões de aproveitamento capitalista perderiam sua legitimidade para se alinhar à uma moral universalista. A reestruturação neoliberal do sistema econômico capitalista exige uma adaptação que ressignifica processos que anteriormente faziam parte da ação de autonomia individual, assumindo, segundo os autores, a forma de exigências, disciplinamentos ou inseguranças que produzem um efeito de dissociação social.

A inserção do requisito de qualificação e exigência de atitude introduzidos no processo econômico substituem a ideia do dever social atrelado ao trabalho, presentes em Hegel e Durkheim, por uma autorrealização experimental. Com isso, segundo os autores, se justifica a 
eliminação do direito de pertencer à empresa e de seguridades legais. Nos postos bem remunerados, a exigência de "atitude criativa e de indeterminação biográfica" (Hartmann \& Honneth, 2009, p. 405) fazem parte do pacote de serviços a serem prestados às empresas no denominado capitalismo de redes ${ }^{6}$. De quem dispõe da venda de sua força de trabalho se espera não apenas o cumprimento de tarefas acordadas previamente na contratação, mas também a disposição para alcançar resultados a partir de projetos autônomos, utilizando suas competências formais e recursos comunicativos e emocionais.

Os desempenhos relevantes para o trabalho passam a exigir a aplicação para fins laborais de capacidades que antes eram utilizadas apenas no âmbito privado. "A racionalidade econômica, poderia dizer-se, está sendo colonizada em termos de mundo da vida" (Hartmann \& Honneth, 2009, p. 406). A pretensa solidariedade de antes passa a integrar a esfera econômica num aproveitamento marcado pela reciprocidade assimétrica. Algumas consequências da "informalização do econômico e economicização do informal" são apontadas pelos autores.

Há uma dificuldade de diferenciar os aspectos instrumentais e não instrumentais das relações intersubjetivas, modificando a percepção dos sujeitos sobre os verdadeiros propósitos que motivam a aproximação de outras pessoas. No capitalismo de redes os sujeitos também são estimulados a conexões laborais mais ligadas a seus interesses autênticos, ao tempo em que se deparam com premiações àquelas personalidades que respondem de maneira flexível a novos projetos. Neste caso, o "significado originalmente emancipador do ideal de autenticidade se tenha convertido em um instrumento legitimador de conexões de aproveitamento capitalistas" (Hartmann \& Honneth, 2009, p. 407). Além disso, os trabalhadores só são reconhecidos em suas competências no aqui e agora, excluindo da memória organizacional méritos passados, o que conduz a uma hierarquia bastante instável. Neste contexto, premiações por idade ou tempo de serviço ficam cada vez mais escassas. Finalmente, os critérios objetivos que permitiam aos sujeitos estabelecer parâmetros sobre o valor de suas qualificações e contribuições não estão bem determinados, o que pode incentivá-los a buscar cada vez mais reconhecimento em lutas de economia da atenção fora da esfera de trabalho. O exemplo dado por Hartmann e Honneth é o de talk shows televisivos.

Para Honneth (2008), dada a diferenciação entre as formas de trabalho, são os próprios sujeitos, partindo da análise das estruturas de trabalho a qual pertencem no mundo social, que

\footnotetext{
${ }^{6}$ Capitalismo de redes: se caracteriza em si mesmo por tendências de absorver ilimitadamente as competências de ação subjetivas, apagando assim os limites entre a esfera privada e a laboral-pública (Hartmann \& Honneth, 2009, p. 405).
} 
podem estabelecer as exigências morais para suas práticas cotidianas. Para isso, é necessária a voz dos afetados, de modo que eles tragam o seu mal-estar à cena, pois são eles que reagem às relações de trabalho existentes, pois “[...] nas condições dadas há sofrimento e não apenas predomínio da indiferença, que há luta e exigências não apenas reações de apatia estratégica" (p.65).

Por esta razão, a escuta de pessoas com nanismo se tornou o método viável para a compreensão de suas experiências no mundo do trabalho. Sua descrição pode ser encontrada a seguir. 
3.

Objetivos 


\subsection{Objetivo geral}

- Compreender a vida de trabalho para pessoas com nanismo através de uma análise psicossocial.

\subsection{Objetivos específicos}

- Identificar as consequências da estigmatização na vida social de pessoas com nanismo;

- Analisar as consequências da estigmatização de pessoas com nanismo na esfera do trabalho;

- Compreender as possibilidades de reconhecimento no trabalho de pessoas com nanismo. 
4.

Método 
Este capítulo dedica-se à apresentação dos procedimentos metodológicos utilizados para desenvolver este trabalho e atender aos seus objetivos. Primeiramente apresenta-se a caracterização da pesquisa, cujos contornos levaram ao desenvolvimento de uma abordagem qualitativa. Em seguida, apresenta-se a estratégia de pesquisa, que buscou informações sobre o problema levantado junto às pessoas com nanismo, através de entrevistas. Na sequência, são descritos os procedimentos referentes à coleta de dados e análise dos resultados obtidos com esta investigação. Ao final, estão situadas as categorias de análise elencadas para o estudo.

\subsection{Caracterização da pesquisa}

Esta investigação está inserida em uma abordagem qualitativa dos fenômenos sociais, em que a construção do conhecimento ocorre pela compreensão e a interpretação do fenômeno, utilizando como fonte de informações os significados que os participantes da pesquisa atribuem à realidade de suas experiências. Como um ser social, que produz seus conhecimentos e constrói sua realidade intersubjetivamente via narrativas, discursos e práticas sociais (Ribeiro, 2017), cada depoente produz uma leitura da realidade sobre si e sobre o mundo que lhe é muito singular, "sendo um discurso sobre a realidade, nunca a realidade mesma” (Ribeiro, 2017, p. 267).

Para Triviños (2015, p. 129), “os significados, a interpretação, surgem da percepção do fenômeno visto num contexto". Esses significados, as relações e participação no ambiente, são produtos de uma visão subjetiva, e os resultados são expressos em narrativas e ilustrados com declarações das pessoas para dar o fundamento concreto necessário.

Para atender a uma função heurística, a pesquisa exploratória e descritiva não se delineou como uma opção, mas sim um caminho inevitável para se abrir um campo de estudos ainda carente de formulações. Diante da escassez de estudos na área do trabalho de pessoas com nanismo, somente pela imersão no campo, buscando conhecer os elementos que atravessam a vida de quem vive com nanismo, a partir de suas próprias narrativas, é que se poderia obter a essência a ser apreendida e organizada em forma de ciência.

Para isso, uma abordagem prévia no campo foi realizada na fase de validação deste estudo. A raridade desta displasia que causa baixa estatura faz com que esta população esteja geograficamente dispersa (Kruse, 2001), tornando mais difícil localizar participantes para esta pesquisa. Para a formação de algumas ideias a respeito da problemática, optou-se pela imersão no campo, inicialmente virtual, por meio de redes sociais na Web, como o Facebook, 
onde comunidades são criadas para reunir membros com acondroplasia. Em muitos grupos fechados, foi enviado o convite na espera de que algum moderador pudesse aceitar a participação, o que ocorreu rapidamente.

Estes contatos progrediram rapidamente para conversas individuais, ainda na Web, e depois para a participação em eventos de confraternização de pessoas com nanismo, onde foi possível observar a dinâmica de conversas que surgem espontaneamente entre elas. $\mathrm{O}$ contorno mais delineado das ideias de execução deste estudo surgiu a partir daí.

Devido à falta de apoio referencial para tratar especificamente do tema "trabalho de pessoas com nanismo", sentiu-se a necessidade de fazer um estudo piloto, de modo a testar a pertinência dos dados encontrados ao objetivo e técnica de pesquisa propostos, e também para obter um direcionamento da literatura que embasaria as reflexões suscitadas pelos achados. $\mathrm{O}$ êxito nesta etapa deixou a passagem aberta para o prosseguimento do estudo nesta conformidade, como é descrito em detalhes a seguir.

\subsection{Procedimentos}

Esta pesquisa não seguiu uma sequência rígida de etapas, em que primeiro se faz a coleta de dados para depois passar à análise. A imersão no campo foi acontecendo aos poucos, ao tempo em que materiais disponíveis na $W e b$, com relatos de pessoas com nanismo, e conversas com elas por meio das redes sociais também compunham o material para a elaboração e aprofundamento nesta problemática, de modo a melhor alimentar a ação de investigação.

A escolha dos participantes da pesquisa se deu de forma aleatória, pois partiu de uma aproximação gradual, feita inicialmente por meio de busca, em redes sociais na Web, de grupos de pessoas com nanismo. A intenção era encontrar pessoas com vidas comuns, de modo a não direcionar a pesquisa na busca daqueles já reconhecidos como artistas na mídia, embora não fosse objetivo excluir estes últimos da pesquisa. Como a Associação de Pessoas com Nanismo, apesar de hospedar uma página na Web, não oferecia resposta à tentativa de contato, o primeiro passo para chegar a estas pessoas foi via $\mathrm{W} e b$, com a inserção em grupos ali hospedados. Essas conversas iniciais abriram caminho para uma aproximação presencial, ocorrida em Atibaia (SP), no ano de 2016, por ocasião de uma confraternização promovida para a celebração da Lei no 13.472 (Brasil, 2017), que institui o Dia Nacional de Combate ao Preconceito contra as Pessoas com Nanismo, celebrado no dia vinte e cinco de outubro. Dali 
em diante foram formados alguns vínculos pessoais e apresentada a proposta da pesquisa para algumas pessoas, o que serviu como "cartão de visita" para ganhar a confiança delas, visto que os participantes destes grupos são pessoas que tem a deficiência e os seus familiares.

A partir deste encontro e do interesse demonstrado por algumas pessoas em participarem da pesquisa, foram agendadas algumas entrevistas que se realizaram na data, horário e local previamente acordados. Nenhuma entrevista foi realizada no ambiente de trabalho do participante. Priorizou-se o contato direto com cada um, em forma de entrevista, em busca da singularidade de suas interpretações a respeito de fatos e vivências cotidianas.

\subsection{Participantes}

Pelo compromisso ético firmado de manter confidencial o nome dos sete participantes, foi solicitado a eles que escolhessem um nome fictício para identificá-los na apresentação das narrativas. Alguns deles se recusaram e disseram preferir que no trabalho constasse seu nome verdadeiro, o que foi atendido. Respeitando estas decisões, os entrevistados foram identificados como João, Ney, Pedro, Marcela, Ricardo, Joaquim e Leonardo. Foram omitidas das narrativas trechos ou palavras passíveis de identificação de sua identificação. O período de realização das entrevistas foi de novembro do ano de 2016 até janeiro de 2018. Foram entrevistadas sete pessoas, sendo seis homens e uma mulher, com idades entre 22 e 53 anos, nascidos na cidade de São Paulo ou que para ali imigraram há, pelo menos, 16 anos. Todas as entrevistas foram realizadas nesta cidade, local em que o número absoluto de empregos formais de pessoas com deficiência é maior. Segundo Anuário do Sistema Público e Emprego, Trabalho e Renda 2015, do DIEESE, somente o Estado de São Paulo concentra mais registros de empregos formais para este conjunto de trabalhadores do que as regiões Norte, Nordeste e Centro-Oeste somadas. São 116.952 empregos no Estado de São Paulo. Além disso, como metrópole, a variedade de ocupações é bastante ampla, o que poderia sugerir maior leque de opções e experiências de trabalho para os participantes.

\subsection{Instrumento}

Foram realizadas entrevistas semiestruturadas e, ainda na fase do estudo piloto desta pesquisa, decidiu-se que as entrevistas com as pessoas com nanismo se dariam em torno de 
um eixo questionador principal: o trabalho. Outros questionamentos surgiram no decorrer da conversa, de modo a suscitar narrativas, deixando aberta a possibilidade para que cada conversa, com cada um, gerasse o seu próprio conteúdo, de forma a atender tanto à demanda que o entrevistado queria comunicar, quanto ao direcionamento de questões que atendem à finalidade deste estudo, como recomenda Bardin (2016).

Os questionamentos procuraram respeitar o caminho escolhido pelo participante ao falar do tema e o ritmo narrativo do depoente, como sugere Gonçalves Filho (2003). Este caminho se mostrou eficaz para alcançar os objetivos deste estudo, visto que as narrativas construídas partiam de aspectos psicossociais de ter o nanismo, como condição que engendrou experiências em todas as esferas da vida, inclusive no trabalho.

Para chegar mais precisamente na narrativa relacionada ao tema "trabalho", outras perguntas de caráter demográfico e que também contemplam a história de vida destas pessoas, foram introduzidas. Tendo em mente este "caminho" já experimentado nas entrevistas iniciais e o alcance dos objetivos propostos, criou-se um roteiro semiestruturado de temas, em torno dos quais se desenvolveu a entrevista. Em consonância com os objetivos traçados para este estudo, estes temas (apresentados no Quadro 1) foram tomados como referência para a análise dos resultados.

Ao todo, foram realizadas sete entrevistas, sendo três na fase piloto e quatro posteriormente. Junto ao entrevistado, inicialmente deu-se uma exposição geral dos propósitos da entrevista e da pesquisa, do contexto em que ela surgiu no percurso de estudos sobre pessoas com deficiência e mercado de trabalho, da especificidade desta questão relacionada às pessoas com nanismo, área ainda carente de estudos científicos.

Preliminarmente, também foi apresentado o Termo de Consentimento Livre e Esclarecido [TCLE] (vide Anexo 1) para que o entrevistado soubesse o que se deseja dele e qual seria sua contribuição para a pesquisa. Suscintamente, foi explicitado o método de tratamento dos dados ali recolhidos, o que justificava a necessidade da gravação da conversa, de modo a respeitar integralmente a narrativa gerada nesta etapa de coleta de dados. Sobre o que seria dito, foi ressaltado que a fala seria espontânea, orquestrada segundo pensamentos e sentimentos evocados naquele momento.

Como afirma Bardin (2016):

A subjetividade está muito presente: uma pessoa fala. Diz "Eu", com o seu próprio sistema de pensamentos, os seus processos cognitivos, os seus sistemas de valores e de representações, as suas emoções, a sua afetividade e a afloração do seu inconsciente. Cada pessoa serve-se dos seus próprios meios de expressão para descrever acontecimentos, práticas, crenças, episódios passados, juízos... (p. 94). 


\subsection{Análise dos dados}

A análise de conteúdo foi utilizada para tratar sistematicamente as narrativas produzidas pelos entrevistados. Como sugere Bardin (2016, p. 34), para "dizer não à ilusão da transparência dos fatos sociais", esta técnica permite que a compreensão espontânea do pesquisador possa ser afastada pelo uso da técnica apurada. Para a autora, a análise de conteúdo busca uma correspondência entre as estruturas semânticas ou linguísticas e as estruturas psicológicas ou sociológicas dos enunciados. Para isso, o analista não deve se voltar apenas para a compreensão do sentido da comunicação, mas sobretudo para as significações embutidas que a mensagem principal pode revelar. Portanto, a análise de conteúdo não pode ser a tradução do que o sujeito está dizendo (Triviños, 2015). O fenômeno se apresenta a partir da aparência, mas ele oculta coisas que precisam ser reveladas para se chegar ao concreto. É desmontar a aparência e buscar os múltiplos determinantes que levam a isso, embora uns estejam próximos e outros distantes, procurando "conhecer o que está por trás das palavras sobre as quais se debruça” (Bardin, 2016, p. 50).

Para análise de conteúdo, foram seguidas as fases preceituadas por Bardin (2016). O início do processo se deu pela transcrição do material, na íntegra, de pouco mais de treze horas de gravação do conteúdo verbal, seguida da leitura de todo o material, a fim de destacar falas e significações que respondiam mais diretamente às questões de pesquisa. $O$ procedimento de repartição do material seguiu a orientação "do particular para o todo", ou seja, partiu-se de elementos particulares de cada entrevista para o reagrupamento progressivo com os seus semelhantes destacados em outras entrevistas. Desses processos de síntese partiuse para a reunião de vários itens de significação sob a forma de categorias analíticas temáticas, cujo título foi atribuído pelo conteúdo da pergunta direcionada ou pelo próprio conteúdo verbal dos participantes.

Diante do paradoxo que normalmente se apresenta em análises que tentam sintetizar a totalidade dos dados, unindo semelhanças para privilegiar ocorrências regulares e excluindo o que é singular, específico, optou-se por fazer a análise que assume tanto o ponto de vista geral e homogêneo, quanto a análise de alguns aspectos específicos, a fim de contemplar os diversos elementos significativos singulares a cada entrevistado. Não se deve ter aí um problema, visto que não é objetivo de um estudo qualitativo fazer generalizações. Como ressalta Bardin (2016), “o acontecimento, o acidente e a raridade possuem, por vezes, um sentido muito forte que não deve ser abafado" (p. 146). 
Os temas foram desmembrados em subtemas, de modo a tornar mais elucidativas as significações atribuídas pelos participantes à questão. Uma matriz que reúne temas e subtemas deles decorrentes foi construída, conforme demonstrado no Quadro 1, para facilitar a análise. Ela tem a função de agregar os enunciados que emergiram das entrevistas em uma listagem sistematizada, denominada grelha de análise de conteúdo, que remete às variáveis encontradas a partir do recorte de cada tema. A seleção de trechos de discursos foi necessária para oferecer evidências dos elementos presentes na mensagem dos participantes, respeitando, sempre, o sentido das narrativas integrais.

$\mathrm{Na}$ apresentação dos resultados, por vezes serão utilizados trechos mais longos das entrevistas, uma vez que separar as descrições poderiam comprometer o contexto no qual eles situam sua narrativa e, consequentemente, distorcer seus significados. Segundo Bogdan e Biklen (1994), um bom trabalho qualitativo é documentado em boas descrições provenientes dos dados para ilustrar e substanciar as asserções feitas.

Para que fossem consideradas boas categorias, foram obedecidas regras técnicas enunciadas por Bardin (2016): a exclusão mútua (cada elemento só pode existir em uma categoria), homogeneidade (princípio único de classificação das categorias), pertinência (cada categoria pertence ao quadro teórico), objetividade e fidelidade (igual codificação para todas as partes do material) e produtividade (fornecimento de resultados férteis).

Para se chegar ao objetivo deste trabalho, a entrevista inicialmente foi conduzida de modo a conhecer as consequências da estigmatização na vida em geral da pessoa com nanismo. Estas respostas seriam uma ponte para se chegar à uma possível extensão ou reprodução dessa estigmatização na esfera do trabalho. Seguindo os objetivos norteadores desta pesquisa, adultos com nanismo acumularam experiências que suscitam reconhecimento no mundo do trabalho, de onde emergiram as categorias temáticas e os subtemas, conforme exposto no Quadro 1 a seguir. Como uma pesquisa exploratória, as mesmas foram definidas $a$ posteriori, a partir do que foi verbalizado pelos entrevistados.

Como será descrito no próximo capítulo, os participantes revelaram muitos aspectos de suas interações sociais, o que não significa que em todas elas, o tempo todo, ocorra o que foi descrito por eles, mas que algumas experiências muito similares e repetitivas permitem generalizar este entendimento de aspectos psicossociais para um grande número de pessoas deste grupo populacional. 
Quadro 1 - Categorias de análise temática

Objetivo Geral: Compreender a vida de trabalho para pessoas com nanismo através de uma análise psicossocial

\begin{tabular}{|c|c|c|}
\hline Objetivos Específicos & Temas & Subtemas \\
\hline \multirow{5}{*}{$\begin{array}{l}\text { Identificar as } \\
\text { consequências da } \\
\text { estigmatização na vida } \\
\text { social de pessoas com } \\
\text { nanismo }\end{array}$} & Família & \\
\hline & Trajetória educacional & \\
\hline & \multirow[t]{3}{*}{ Relações sociais } & $\begin{array}{l}\text { Identidade } \\
\text { estigmatizada }\end{array}$ \\
\hline & & $\begin{array}{l}\text { Reações da pessoa com } \\
\text { nanismo à estigmatização }\end{array}$ \\
\hline & & Humilhação \\
\hline \multirow{5}{*}{$\begin{array}{l}\text { Analisar as } \\
\text { consequências da } \\
\text { estigmatização de } \\
\text { pessoas com nanismo na } \\
\text { esfera do trabalho }\end{array}$} & \multirow[t]{5}{*}{ Vida de trabalho } & $\begin{array}{l}\text { Dificuldades de inserção } \\
\text { no mercado de trabalho }\end{array}$ \\
\hline & & Trabalho desprotegido \\
\hline & & $\begin{array}{l}\text { Influência do estereótipo } \\
\text { nas oportunidades de } \\
\text { trabalho }\end{array}$ \\
\hline & & Lei de Cotas \\
\hline & & $\begin{array}{l}\text { Humilhação e preconceito } \\
\text { no trabalho }\end{array}$ \\
\hline
\end{tabular}

\begin{tabular}{l} 
Compreender as \\
possibilidades de \\
reconhecimento no \\
trabalho de pessoas com \\
nanismo \\
\hline Fonte: Elaborado pela autora
\end{tabular}

\subsection{Cuidados éticos}

A pesquisa com participantes estigmatizados levanta uma série de questões éticas desafiadoras para o pesquisador. Os participantes, pessoas com nanismo, geralmente estão expostos à discriminação e preconceito em razão de sua aparência física. O desrespeito, a estigmatização, entre outros elementos, já foram mencionados pelos estudos consultados a respeito do estigma social do nanismo. No entanto, é preciso considerar que cada pessoa é singular e, o que para alguns pode se repetir em semelhança tais fenômenos, para outros não. Por isso, o pesquisador precisa ter bastante cuidado para que, conhecendo algo do campo, não faça perguntas "como quem já sabe a resposta", como aponta Gonçalves Filho (2003, p.13) e para que não seja mais uma pessoa a confirmar ou sugerir estas pressuposições. 
Numa entrevista, suscitar narrativas requer trabalhar com a memória do participante. Uma lembrança suscita o pensamento e o discurso, mas também a percepção e a fantasia, imagens e afetos, aprovação e condenação, espontaneidade (Gonçalves Filho, 2003), que podem trazer à tona sentimentos e histórias provenientes de situações desagradáveis para o participante.

Como afirma Gonçalves Filho (2003):

o que foi vivido por alguém, quando alterado em gesto e voz própria, já não é simplesmente a coisa vivida. O que foi vivido vem misturado com quem o viveu, vem modulado por seu sentimento e por alguma resposta sua: o que foi vivido vem como aquilo que alguém sofre e interroga (p. 8).

Estes riscos podem ser psicológicos, ocorrendo pela alteração da percepção do participante a respeito de si próprio, pelo sofrimento emocional decorrente do relato de sua vivência com o estigma, que desperta sentimentos como ansiedade, baixa valoração social, vergonha, tristeza, entre outros. Na conversa com a pessoa participante, perguntas poderiam trazer à tona questões que ele já tinha consciência e outras, ainda não percebidas por ele/ela.

No entanto, apesar desta pesquisa manipular variáveis com potencial para gerar estes sentimentos, considera-se que ela apresentou risco mínimo para os seus participantes, visto que os procedimentos de pesquisa não sujeitaram os participantes a riscos maiores do que os encontrados nas suas atividades cotidianas. E todos construíram bem suas narrativas e lhes foi dito que, se algo os incomodasse, poderiam parar de falar sobre assunto, ou poderiam pedir auxílio à pesquisadora para acolher e refletir a temática emergente. 
5.

Apresentação e Análise dos Resultados 
Neste capítulo, serão apresentados e discutidos os resultados das entrevistas realizadas. Os objetivos específicos foram o eixo de organização para esta apresentação, reunindo em torno deles os temas e subtemas a eles correspondentes, modelo que também será seguido para a apresentação que segue. A descrição dos dados e a discussão dos mesmos atende à uma divisão em três partes, cada uma alinhada ao objetivo proposto. Mas antes de nos direcionarmos mais propriamente para esta análise, consideramos relevante descrever alguns aspectos da vida de cada um dos entrevistados que não foram contemplados na análise, por não fazerem parte mais diretamente do objeto de estudo, mas que auxiliam a compreender um pouco mais a respeito de quem fala.

\subsection{Sobre os entrevistados}

A captação de dados subjetivos para esta pesquisa qualitativa exigiu uma proximidade social com os participantes que abriu caminho para uma interação espontânea entre as partes. O tipo de entrevista foi favorável para que eles ficassem à vontade e contribuiu para que aspectos afetivos e mais íntimos, contados quase como em tom de confidência, viessem à tona em cada depoimento. Do ponto de vista em que falam, como intérpretes da própria vida e do mundo no qual vivem com uma existência singular, as lembranças transformadas em narrativas traziam elementos do espaço social, da condição social, organização familiar e dos aspectos afetivos e valorativos de suas percepções de realidade. Dada a igualdade da acondroplasia, as diferenças que por ali se estabeleceram constituíram modos de construção da vida presente. Por esta razão, acreditamos ser importante apresentar aspectos da vida de cada entrevistado que não irão aparecer nas narrativas tomadas de exemplo pela análise, de modo que o leitor possa conhecer, ainda que pouco e com base no que decidimos recortar para apresentar aqui como relevante, um pouco de cada um.

JOÃO: Homem, 43 anos, solteiro. Nasceu em São Paulo. Tem uma família com seis irmãs, e que apenas ele tem nanismo. Tem formação em Artes Cênicas e graduação em Administração, concluída há pouco tempo. Teve uma trajetória escolar irregular, muitas vezes interrompida e com diversos episódios de revolta pelo preconceito que enfrentava. Ressaltou, por muitas vezes, o sofrimento com o pai, alcoolista, e a dificuldade financeira da mãe, que trabalhava como empregada doméstica, para criar os filhos. Destacou a companhia das irmãs nos momentos mais difíceis e no enfrentamento do preconceito. Seus primeiros trabalhos foram como office-boy, caixa de lanchonete, auxiliar na secretaria de uma universidade 
privada. Concomitantemente, fazia trabalhos em eventos. Aos 23 anos começou a se interessar pelo teatro através do convite de um produtor de TV, onde obteve formação cênica. Trabalhou 15 anos em televisão, fazendo programas voltados para entretenimento, campanhas publicitárias e teatro. Através da Lei de Cotas, foi contratado por um banco e lá trabalha como analista há 11 anos.

NEY: Homem, 45 anos, solteiro, natural de São Paulo. Tem 3 irmãos mais velhos, sendo o único na família com nanismo. Graduado em Letras, mas com trajetória educacional irregular. Seu primeiro trabalho foi como professor particular de crianças em seu próprio bairro. Seu primeiro emprego formal foi em uma escola de Ensino Básico, ocupando uma vaga reservada para pessoa com deficiência. Lá trabalhou como auxiliar de secretaria e auxiliar de biblioteca. Depois de quatro anos e meio nesta escola, fez cadastro em uma agência de intermediação de mão de obra especializada para pessoas com deficiência e foi contratado por uma empresa de Telecomunicações, onde está há cinco anos. Desde que conheceu uma companhia de teatro, através de uma associação de pessoas com nanismo, começou a atuar, que é, até hoje, juntamente com a atividade de aulas particulares, suas atividades paralelas ao emprego nesta empresa de telecomunicação.

PEDRO: Tem 42 anos, casado, uma filha. Nasceu em Palmeira dos Índios, estado de Alagoas. Tem seis irmãos, mas é o único que possui nanismo. Em sua cidade natal, trabalhava limpando roça, plantando milho, feijão, mandioca com os seus irmãos, de onde saiu para São Paulo em busca de outras oportunidades de trabalho. Tem Ensino Fundamental completo. Mora há mais de 16 anos na cidade de São Paulo, onde tentou retomar os estudos sem sucesso. Até hoje acumula duas carteiras de trabalho, sem registro. Trabalhou como vendedor de passes de transporte e cartão telefônico, guia para cego, vendedor ambulante. Ao conhecer uma pessoa que também tinha nanismo e já trabalhava na televisão, foi convidado para integrar elenco de programas de humor de grande audiência na televisão, onde, ocasionalmente, trabalhou mediante contrato. Foi palhaço em rodeios e viajou para outros países fazendo trabalhos em circos. Atualmente, trabalha em eventos esporadicamente.

MARCELA: 22 anos, solteira. Natural de São Paulo. Tem um irmão, sem nanismo. Trajetória educacional regular. Cursou o ensino fundamental completo em uma escola na qual sua mãe era professora, saindo de lá para cursar o Ensino Médio, onde também ficou até sua conclusão. Na data da entrevista, era concludente do curso superior em Design Gráfico. Teve dois trabalhos, ambos na sua área de formação, sem registro na carteira de trabalho. Fez poucos trabalhos em eventos. 
RICARDO: 40 anos, separado. Sua ex-companheira não tinha nanismo. Nasceu na cidade de Pedra Branca, Estado do Ceará, e mudou-se para São Paulo há mais de 15 anos em busca de trabalho. Tem duas irmãs mais novas, sem nanismo, que, juntamente com sua mãe, estavam sob sua responsabilidade financeira, tendo em vista a morte precoce do pai. No Ceará só trabalhou na lavoura. Não concluiu o Ensino Fundamental. Sem ter onde morar em São Paulo, morou embaixo de viadutos. Trabalhou em panfletagem, venda de cartão telefônico e passagens para ônibus. Enquanto assistia à gravação para a TV de um programa de humor, realizada numa praça no centro de São Paulo, foi chamado para integrar o elenco do mesmo, onde ficou por mais de dois anos. No momento, faz eventos esporadicamente.

JOAQUIM: 53 anos, casado com uma mulher que também tem nanismo. 'Nasceu na cidade de Macha Caliz, no Estado de Minas Gerais. O pai faleceu antes do seu nascimento. Tem oito irmãos, todos sem nanismo. Sua mãe o trouxe para São Paulo ainda criança para fazer tratamento de saúde, sendo acompanhado posteriormente pelo restante da família. Sua trajetória educacional foi irregular, concluindo recentemente o curso tecnólogo em Audiovisual. Antes de ser contratado por meio da Lei de Cotas, foi vendedor ambulante e fez eventos direcionados ao entretenimento, campanhas publicitárias, programas de humor. Em sua trajetória de trabalho, há várias experiências de emprego, com registro em vagas reservadas para pessoas com deficiência. No momento da entrevista, estava empregado em um banco.

LEONARDO: 26 anos, solteiro. Filho único. Natural de São Paulo. Trajetória regular de educação. Graduado em Gestão do Turismo. Trabalha desde os 15 anos como ator, é poeta e escritor. Através da Lei de Cotas, trabalhou em companhias de viagem e em uma empresa do setor financeiro como auxiliar administrativo. Fez campanhas publicitárias, eventos, peças de teatro e novelas na TV. Depois que projetos artísticos passaram a lhe exigir mais tempo e trouxeram maiores rendimentos financeiros, decidiu dedicar-se apenas à esta área.

A seguir, serão apresentados os resultados obtidos nesta pesquisa concomitantemente à discussão dos mesmos. Os temas foram organizados em torno dos objetivos específicos, incorporando todos os subtemas a ele relacionados.

\subsection{As consequências da estigmatização na vida social de pessoas com nanismo.}

A seguir, serão apresentados e discutidos os resultados relacionados à Família, Trajetória Educacional e Relações Sociais. 


\subsubsection{Família}

Todos os entrevistados declararam ser a única pessoa da família a ter nanismo, o que é comumente apontado pelos estudos clínicos, por tratar-se de uma mutação no gene. Seja como filho único ou numa família com mais irmãos, a maior parte deles indicou uma superproteção por parte dos pais, numa tentativa de protegê-los de situações sociais de risco. Dentre as medidas adotadas, estava uma socialização mais restrita a ambientes já familiarizados com a sua condição física e a companhia frequente de algum familiar em atividades sociais rotineiras, como ir à escola, por exemplo. Para a única mulher entrevistada, esse cuidado tem perdurado até o momento, na vida adulta. Na atualização da lembrança, as justificativas adotadas pelas famílias para este cuidado foram relacionadas à mobilidade reduzida, à insegurança pela exposição de uma pessoa com baixa estatura aos problemas cotidianos de uma grande cidade e à própria estigmatização, de modo a evitar o sofrimento frente à hostilidade social dela decorrente.

João: Medo. Dependência. Porque minha dependência era ter minha irmã, principalmente a V., que sempre andava comigo, minha mãe e a insegurança de você ser um ser e andar sozinho. Entendeu?

Ney: É a proteção, o cuidado. Natural, mas é exagerado [...] Aí, meus irmãos iam buscar, também me traziam enganchado ... Aí trazia enganchado no pescoço porque o colégio tinha algumas ruas distantes né.

Marcela: Ela [a mãe] acha que eu sou sensível a assalto, sensível ao sequestro, sensível à pessoa apontando e eu não saber reagir. Ela acha que eu não sabia reagir. [...] Era ir prá escola com ela. Voltava da escola com ela e ficava em casa. Aí comecei a sair. Comecei a sair com dezesseis anos, mas era prá festinha. Mas aí meus pais me deixavam lá, depois me buscavam. [...] Sempre era um ambiente protegido. Até os meus dezoito, eu acho. Aí eu comecei a tentar a ter a minha liberdade. [...] Aí quando eu falei prá eles que eu precisava trabalhar, e não sei o quê, a minha mãe falou: ah, procura um lugar perto de casa. Aí eles queriam me levar. Aí eu: tá bom. [...] Minha mãe me buscava e me levava. Eu não ia sozinha.

Joaquim: Então, eu não tive a convivência, eu não fui criado com a convivência de outras pessoas [...] Ainda mais eu, que criei preso. Preso assim, dentro de casa. [...] minha mãe já acostumou a sair comigo desde criança.

Em pesquisas com famílias de pessoas com nanismo, Ablon (1990) aponta que a falta de conhecimento sobre esta condição genética pode criar um comportamento ambivalente dos pais em relação aos filhos. Segundo o autor, a maioria dos pais de estatura mediana não viu mais do que uma ou duas pessoas com nanismo antes do nascimento do próprio filho, o que contribui para que tenham formadas poucas impressões a respeito de como seria sua vida, além das dificuldades em lidar com os estereótipos míticos e imagens culturais construídas a 
respeito dele na sociedade. Para os pais, conciliar estereótipos míticos e imagens culturais com a realidade do próprio filho, guardando as semelhanças aí existentes, pode ser problemático por toda a vida. Em decorrência disso, eles podem tentar protegê-los das consequências da estigmatização.

De uma forma mais direta, o imaginário social, que atrela a pessoa com nanismo a um artefato dos espetáculos circenses também se fez presente nas lembranças do entrevistado de maior idade.

Joaquim: E teve um dia que eu sumi, né? Porque eu fiz um caminho diferente e sumi. E ela ficou preocupada, tadinha. Ela achou que alguém tinha pegado eu prá vender pro circo. Porque antigamente anão só era prá ser vendido em circo, pra trabalhar em circo [...] que ela falava prá mim que todo mundo... a pessoa acha você engraçadinho [...] ela andava comigo segurando na minha mão, com medo. E aí ela ficou desesperada. Falou: pronto, aconteceu, roubaram meu filho de mim, ele foi trabalhar num circo. Pegaram ele prá trabalhar num circo.

Segundo Ablon (1990), embora o nanismo também seja alvo de um estigma social, assim como outras diferenças físicas, há fatores cruciais em afetam as pessoas e suas famílias de maneira específica. Uma delas, é que em nossa tradição cultural os anões pertencem ao mundo mítico e não ao mundo da realidade cotidiana, o que desperta grande curiosidade sobre eles. Como destaca o autor, dada a raridade de encontrar alguém com estas características físicas, num encontro casual, as pessoas passam a encará-los de forma incrédula, muitas vezes fotografando sua imagem.

Esta proteção e cuidado com o filho com nanismo é atravessada por questões socioeconômicas e culturais. Os entrevistados, PEDRO e RICARDO, que passaram a infância e grande parte da juventude na região onde nasceram (Nordeste brasileiro), relataram uma vivência diferente dos demais. Não foi mencionado qualquer forma de cuidado diferenciado em relação ao tratamento dispensado aos outros membros da família. A inserção precoce no trabalho em lavoura, comum na região, também não lhes foi poupado em razão da deficiência.

Pedro: Os meus irmão era normal. Era tudo grandão. Eles me respeitavam sabe. E eu era, digamos que depois de mãe e pai, eu mandava. Porque eu dizia: é assim, era assim e acabou. Que eu era na época o mais velho na casa...

Ricardo: Quando o meu pai morreu, deixou uma menina de sete anos e outra de cinco anos. E eu é quem tinha que trabalhar prá sustentar elas, de leite, essas coisas. Elas comiam leite ainda.

Ser tratado com igualdade de condições em relação aos demais filhos, seguindo até mesmo tradições de respeito ao irmão mais velho, pode ser decorrente de uma outra condição específica a respeito do nanismo apontada por Ablon (1990). Para o autor, embora o nanismo 
seja uma diferença física imediatamente identificável, eles não são deficientes em sentido geral. Todas as partes do corpo estão presentes, em proporções diferentes e a estatura significativamente inferior aos dos seus pares não impede as crianças e adultos com acondroplasia de terem, na maior parte dos aspectos, uma vida comum à de pessoas de estatura mediana.

Os entrevistados descreveram boas relações afetivas com os demais membros da família. Dos sete entrevistados, três perderam o pai ainda muito jovens, mas em todos os casos, o vínculo com a mãe parece ter sido o mais importante. Para um deles, a relação com o pai foi bastante turbulenta ao longo da vida por não ser reconhecido por ele como filho em razão da deficiência. Para Ablon (1990), as expectativas dos pais de uma criança perfeita podem ser frustradas ao saberem que o filho tem acondroplasia, fazendo com que eles também se sintam diminuídos. Segundo Honneth (2003), a autoconfiança, indispensável para a participação autônoma na vida pública, depende do reconhecimento nesta relação primária entre pais e filhos no interior da família.

João: Uma coisa que me aflige muito foi na época que meu pai, quando eu nasci, caçula, ele sempre falava que eu não era tipo filho dele, por ter nanismo. E isso afligiu muito, carrego muito esse preconceito comigo hoje, essa diferença. Ele morreu falando nisso, né? Que eu não era filho dele [...] E assim, eu escondo muito da minha família essa ferida que eu tenho no coração. [...] Eu tinha muito carinho da V. [irmã], muita segurança da minha mãe, muita segurança das minhas irmãs.

Quanto às causas do acondroplasia, dois participantes (JOÃO e PEDRO) desconhecem até hoje a origem. Vindos de cidades pequenas, onde são mais escassos os recursos para atendimento em saúde, eles não sabem descrever a razão pela qual têm nanismo, embora reconheçam que têm nanismo. Em geral, a maioria dos participantes passou grande parte da vida sem receber informações suficientes a respeito da sua condição clínica e sobre o que esperar socialmente por causa dela. Também nunca se serviram de alguma forma de apoio psicológico profissionalizado para lidar com ela ao longo da vida.

Marcela: [...] eu acho que eu fiz a primeira pergunta quando eu era muito criança. Acho que eu devia ter uns cinco anos. [...] Eu acho que eu perguntei: Por que que eu sou pequena e os meus amigos são grandes? Minha mãe me explicou. Aí a questão d'eu ter acondroplasia, minha mãe sempre me explicou, mas nunca foi algo além disso, no sentido de como você vai lidar no meio social, como você vai lidar com um relacionamento [...] Não houve uma preparação, porque eles mesmos não tinham tanta informação [...] Meus pais, eles não falavam muito sobre. E eu também não gostava de falar muito sobre. E eu não tinha contato com ninguém, então eu não sabia como resolver aquela situação toda. [...] Meus pais eram muito fechados em questão a isso. [...] Eles não explicavam. 
Apenas um dos participantes relatou que a família teve papel fundamental para tornálo consciente de sua diferença e das respostas sociais em razão dela:

Leonardo: minha família foi muito... muito clara comigo, desde a infância assim. Você é diferente. Você tem uma deficiência. Você tem nanismo. É diferente da sociedade. E você vai sofrer olhares e você vai ter que lutar com isso.

Ao estudarem famílias com acondroplasia, Ablon (2000, 2002) e Hill, Sahhar, Aitken, Savarirayan e Metcalfe (2003) apontaram que as poucas informações fornecidas e as atitudes dos profissionais de saúde na revelação do diagnóstico têm efeito significativo no enfrentamento e adaptação da família ao longo do tempo, contribuindo para gerar mais ansiedade nos pais e pouca compreensão a respeito das consequências emocionais e sociais para a vida do filho. Nestes estudos, a maioria dos médicos tinha pouco ou nenhum conhecimento sobre a acondroplasia e nunca haviam visto ou tratado de algum caso, além de não obterem informação atualizada, ou mesmo corretas. Fotos clínicas ou impessoais de crianças ou adultos com acondroplasia eram mostradas aos pais, de maneira que eram os próprios pais que precisavam buscar informações a respeito de ter uma criança com nanismo. Além disso, os pais precisavam lidar com as percepções da sociedade a respeito de seus filhos e com as imagens na mídia a respeito da pessoa com nanismo, que, para muitos, é a única representação a que têm acesso.

Portanto, pais que buscaram informações por conta própria para compreender mais a respeito da acondroplasia puderam, segundo narrativas acima, orientar melhor os filhos a respeito desta deficiência. Para Ablon (2002), não se pode subestimar a comunicação parental, sendo necessário discutir abertamente questões práticas e emocionais que cercam a condição de filhos com nanismo, abrindo assim, a disponibilidade para lidar com seus medos e preocupações.

\subsubsection{Trajetória educacional}

Para todos os trabalhadores, a escolaridade é um fator preponderante para maiores e melhores possibilidades de inserção no mercado de trabalho. A trajetória educacional repercute na trajetória de trabalho. Para pessoas com deficiência, a baixa qualificação profissional tem sido motivo alegado por empregadores para não cumprimento da Lei de Cotas. Por outro lado, são muitos fatores presentes no ambiente social que afetam e impedem 
que pessoas com deficiência tenham uma trajetória educacional regular, como demonstrado no estudo realizado na dissertação de mestrado sobre "Educação Profissional de Pessoas com deficiência" (Lima, 2012). Para pessoas com nanismo, em especial, alvos de um processo de estigmatização diferente das pessoas com outras deficiências, os elementos que interferem na escolarização têm suas especificidades.

Dos sete entrevistados, apenas dois têm o nível do Ensino Fundamental (PEDRO e RICARDO), sendo que este último não alcançou a sua conclusão. Trata-se daqueles que tiveram que migrar para a cidade de São Paulo em busca de emprego. O trabalho precário e a falta de estrutura familiar que amparasse uma busca incerta por ganhos garantidores da manutenção da vida econômica contribuíram para que o abandono escolar fosse consolidado. Nestes relatos sobre o percurso escolar, não foram narrados episódios de preconceito ou dificuldades em interações sociais em razão do nanismo, ficando evidente apenas a distorção entre idade e série cursada.

Ricardo: A gente ia mais prá escola lá no Ceará era só pra se divertir, né? Só pra brincar com a galera, porque eu já era meio velho, né?

Quanto aos outros cinco participantes, três alcançaram o Ensino Superior com idade acima de 30 anos, o que revela uma trajetória educacional bastante irregular. Para estes, foram comuns experiências de sofrimento relacionadas à estigmatização no ambiente escolar. Preconceitos, insultos e humilhação social faziam parte do cotidiano, como revelado abaixo:

João: Eu tive a infelicidade de tá estudando em uma escola estadual na qual todo mundo me bulinava, zoava comigo. Eu chegava mais revoltado ainda. [...] Eu fiz a $8^{\mathrm{a}}$ série, aí parei um tempo, uns dois anos e voltei para o primeiro, depois parei dois anos, aí fiz o segundo colegial

Ney: [...] a escola que eu fui estudar [...] Tinha uma diretora [...] Ela negou que eu entrasse na escola com sete anos porque ela disse que eu poderia ser pisoteado [...] Aí eu entrei com oito anos.

Joaquim: Então, moral da história, eu atrasei muito na escola. Eu fiquei três anos na segunda série. Parece que a minha cabeça travou. [...] Eu fiquei com trauma. Até hoje. [...] Na escola, né? Porque eu sofri muito preconceito na época. Imagina na década de setenta [...] A criançada toda vinha atrás de mim na hora do recreio [...] eu me trancava lá no banheiro até terminar o recreio. [...] naquela época eu tinha aquele receio de ir na lousa devido às crianças tirarem o sarro de mim, né? [...] ela falava: você vai ter que ir na lousa. Eu ia, subia na cadeira, tudo. Eu alcançava. Mas só que a criançada tirava o sarro sabe, duma maneira... Sabe, era a sala toda. Não tinha esse que não tirava $\mathrm{o}$ sarro, que não gritava, que não... $\mathrm{E}$ as minhas pernas começavam a tremer [...] Ah, ó o anão, ó só a perninha dele, é torta, você já viu. [...] E aí eu não conseguia terminar. 
Estes resultados vão ao encontro daqueles obtidos por Gordon, Crouthamel, Post e Richman (1982), que ao estudarem os efeitos psicossociais da baixa estatura, relataram que crianças e adolescentes com baixa estatura podem enfrentar dificuldades sociais, acadêmicas e psicológicas significativas devido à sua condição, como estigmatização, intimidação, baixa autoestima, distúrbios da imagem corporal, falta de competências sociais esperadas para a idade e retraimento social. Quanto a recusa da escola em receber um aluno com nanismo, é possível que a diretora tenha consigo a ideia de que pessoas com nanismo são perenemente infantis e menos capazes do que seus pares, como assinala Ablon (1990).

Os entrevistados mais jovens, oriundos de famílias com melhores condições socioeconômicas, tiveram trajetória de ensino regular concentrada em poucas escolas, o que lhes permitiu estarem em um ambiente em que sua condição física era familiar a todos. $\mathrm{Na}$ medida em que a escola em que estudavam desde a infância não ofertava mais a modalidade de ensino subsequente, a mudança para uma outra se fazia necessária. Nesses momentos, a consciência da diferença se materializava nas interações sociais. A dimensão prática de si mesmo se apresentava nas reações que sua presença física suscitava nos outros. Medo e curiosidade de outros alunos, desconfiança entre professores sobre sua capacidade cognitiva, foram relatados:

Marcela: Até o Pré, eu estudava na mesma escola que minha mãe trabalhava. Minha mãe é
professora. Então quase a minha vida inteira eu estudei na escola que ela trabalhava. Como eu
cresci ali desde criança e sempre fui muito conhecida, eu era o xodó da escola. [...] Eu acho
que ali eu não percebi nada de diferente. Que eu conhecia desde criancinha todo mundo e tudo
era tranquilo. [...] Aí depois, a escola fechou, quando eu tava no Pré, e aí eu fui pra uma escola
grande. Aí eu senti uma diferença. [...] Então, eu só estudei em duas escolas. E minha mãe não
trabalhava lá ainda. Então, não tinha aquela... Ninguém tinha conhecimento sobre mim ali. [...]
Quando eu cheguei ali tudo passou a ser novo, tanto prá mim quanto pra eles, como pra minha
turma. Aí, eu lembro que a professora, às vezes, pela falta de informação, ela acha que eu não
acompanho [...] comecei a sentir que alunos novos que entravam, depois quando eu tava mais
velha... Aí já tinha um... uma curiosidade. Às vezes, uns não se aproximavam por medo.
Outros se aproximavam por curiosidade e acabavam se surpreendendo. Ou estas pessoas por
medo, quando eu me aproximava se surpreendiam e viam que não era nada daquilo [...] Na
faculdade, mesma coisa. Foi difícil no começo, conhecer as pessoas. Leonardo: Eu era popular, eu era amigo de todo mundo, eu conversava com todo mundo [...] Entrar numa universidade, por exemplo. Então, tem vários olhares.

Para Ablon (2002) e Stace e Danks (1981) várias crianças e pré-adolescentes com nanismo têm sido muito populares ao longo de seus primeiros anos escolares, sendo extrovertidas e sociáveis, com muitos amigos. Para a autora, serem amplamente conhecidos em razão de seu tamanho pode ser um dos fatores desse sucesso social. Money (1967) e Money e Pollit (1966) ao tratarem dos aspectos psicológicos do nanismo, sugerem que a baixa 
estatura da pessoa com nanismo confere a ela um índice de reconhecimento que não depende de qualquer esforço de sua parte. Para os autores, ser popular não significa necessariamente algo positivo, uma vez que também pode ser um fardo essa notoriedade, um instrumento de mortificação para a pessoa. Em uma das narrativas acima, ser o "xodó da escola" remete ao que estes autores classificam como uma situação de "mascote", em que à pessoa é atribuída um papel positivo na estrutura social em razão de seu tamanho.

Mas esta situação não perdura por muito tempo, uma vez que na adolescência esta popularidade, associada a um sentimento de valoração social, pode ir se dissolvendo ao se confrontarem com algumas dificuldades sociais. Em estudos para determinar os efeitos psicossociais da baixa estatura em crianças, Gordon, Crouthamel, Post e Richman (1982), Siegel, Clopper e Stabler (1991) e Stace e Danks (1981) apontam que adolescentes de baixa estatura encontram dificuldades sociais e psicológicas significativas devido à sua condição, tais como retraimento social, autoconceito prejudicado, expressos por baixa autoestima, falta de competências sociais esperadas para a idade, sentimentos de impopularidade e insatisfação. Os resultados mostraram que as crianças classificam sua aparência física e popularidade como satisfatória, mas durante a adolescência sentimentos de conflito interno associados à baixa estatura geralmente se desenvolvem. Como relatado acima, no decorrer do tempo as reações afetivas aos entrevistados foram se modificando com o passar do tempo, indo de uma posição social de popularidade e aceitação, até de estranhamento, medo e desconfiança relativa às capacidades.

Para um dos entrevistados, a decisão para ingressar em uma faculdade e fazer um curso superior foi adiada em razão da lembrança ainda viva do preconceito e humilhação que atravessaram sua vida escolar. Como sofrimento que persiste, resiste e se renova ao longo do tempo (Gonçalves Filho, 2007), os atos de humilhação e os sentimentos do humilhado se relacionam a consequências comportamentais. Como ressalta Arregui (2009), é chamado de "não-comportamento", pois uma pessoa evita uma situação social em que ela já antecipa que poderá sofrer estigmatização social. Evitar fazer uma faculdade seria um dos exemplos.

João: [...] aí a minha chefe falou assim: cara, faz uma faculdade. Eu falei não, eu não quero fazer faculdade. Eu não tenho pique para fazer, né? E outra: neguim vai tirar sarro de mim, vai zoar comigo e aí eu vou prá ignorância. Sempre fui ignorante nesse aspecto. Muito. Impaciente. 


\subsubsection{Relações Sociais}

Sob esta temática, ficaram reunidos os dados e reflexões a respeito da Identidade Social Estigmatizada, as reações da pessoa com nanismo à estigmatização e a humilhação.

\subsubsection{Identidade Social Estigmatizada}

É no dia a dia, no convívio da realidade social, onde se dão as condições intersubjetivas para a relação com os outros. Nestas experiências vividas é que a ideia que um indivíduo faz de si mesmo, a partir das ideias que os outros fazem dele, vai se interiorizando e se consolidando. No mundo das relações sociais é que o estereótipo a respeito daquele que é categorizado socialmente como "anão" encontra múltiplas significações, concretizadas em crenças e atitudes que nutrem a estigmatização de quem reúne seus atributos. Ao longo da vida, as pessoas com nanismo ingressam em diferentes grupos sociais, frequentam diferentes espaços e usufruem deles conforme suas demandas, constituindo um emaranhado de relações sociais que lhes exige comparecer frente a outras pessoas e lidar com as reações decorrentes das atribuições que os outros fazem a seu respeito.

Entre estas atribuições, está o termo "anão", empregado como substituto do seu nome, da sua profissão, da sua origem, de sua pessoa. Como uma personagem reduzida a uma representação estereotipada, edificada sobre lendas, contos infantis e encenações cômicas teatrais e televisas, o humanismo desta pessoa é aprisionado ao imaginário popular, aos elementos culturais vigentes, às concepções morais predominantes e representações construídas a seu respeito. Sob a influência destes discursos sociais é que as pessoas com nanismo vão configurando uma identidade pessoal, interiorizando aquilo que os outros lhes atribuem a partir da representação que fazem delas.

De todas as pessoas entrevistadas neste trabalho, nenhuma deu indicativos de satisfação com esta atribuição para sua identidade. Para eles, as mídias sociais, a falta de informação, a estereotipia que molda a imagem da pessoa com nanismo que chega ao público, são alguns dos fatores que contribuem para que até hoje sua identidade esteja associada ao entretenimento, ao cômico, ao ridículo. A ideia é que esta representação acompanha todas as pessoas com nanismo, que trabalham ou não no meio artístico. Fora da encenação, em uma 
outra atividade, é dela o papel de fazer rir, mesmo que ela esteja envolvida em uma atividade comum do cotidiano.

Na opinião dos entrevistados, a mídia sempre contribuiu para a construção de uma imagem que desvaloriza a pessoa com nanismo. O discurso social presente em programas de humor nacionais que rebaixavam e denegriam pessoas nesta condição física foram determinantes para o reforço do estereótipo e o processo de estigmatização.

Ney: Mas o preconceito prá mídia começou com uma pessoa muito querida no Brasil chamada Renato Aragão. Renato Aragão se ajoelhava e fazia o Ananias e um texto que denegria mesmo. Quer dizer, não podia ser anão [...] Não fazia nada que elevasse, sempre que declinasse a figura do anão [...] enquanto alguém estava achando engraçado. Paralelamente a Renato Aragão, tinha o Nelson Ned, maravilhoso, fazendo sucesso fora.

Marcela: Porque a televisão só usava esse termo. Nunca usava: ah, aquele pequeno; ah, aquele baixinho. Aquele anão de circo, aquele anão de televisão [...] Vem do Entretenimento. Acho que carrega essa parte da chacota. Anão é engraçado, que cai ali, faz graça [...] Meus amigos também não gostam muito [...] eles não gostam do que passa na televisão, porque eles veem que aquilo na televisão não sou eu. Tipo, aquilo na televisão, por trás daquela pessoa tem uma pessoa que tem uma família, tem uma pessoa que batalha todo dia prá ter sustento em casa. É uma pessoa comum. Então eu acho que o anão carrega ainda muito ainda do entretenimento. E é por isso que eu não gosto. Se ele fosse tratado por ser, o anão ser a gente, todos nós, sem preconceito, se é uma pessoa que tem deficiência, que tem as suas limitações, mas vive sua vida, aí tudo bem. [...] A ideia é que anão é tratado como entretenimento.

Joaquim: A gente é... é coisa do outro mundo. É fantasia do outro mundo [...] Se eu sou uma pessoa rica sabe, tô todo engravatado, passo diante do público, a pessoa vai dizer: oh, o anão.

A Little People of America (LPA, 2015), a organização de apoio ao nanismo mais antiga do mundo, defende a abolição do uso da palavra "anão" para se referir às pessoas com nanismo. Para ela, esta palavra é considerada um insulto depreciativo, que nunca foi cunhada como o termo oficial para identificar pessoas com nanismo, mas como um rótulo para se referir a pessoas de baixa estatura que estavam em exibição pública para curiosidade e entretenimento. Para quase todas os membros da LPA, pessoas pequenas, pessoas de baixa estatura, pessoas que tem nanismo ou, simplesmente, seu nome próprio, são usos preferidos. Com base em experiências coletivas dos participantes, usar "anão" para descrever uma pessoa com nanismo é errôneo pois, de acordo com as intenções do usuário da palavra, é utilizada para rebaixar e intimidar. Isso denota que a linguagem tem o poder de causar danos permanentes à autoestima e identidade da pessoa com nanismo.

A combinação de estereótipos culturais e a sua reprodução na mídia de forma cômica, bizarra, colocam as pessoas com nanismo numa categoria específica em relação às pessoas com outras deficiências. Para Kennedy (2003), a dualidade no tratamento dispensado a estas pessoas envolve a sua categorização tanto como maravilhas da natureza quanto uma 
aberração. Para Adelson (2005b) e Skakespeare, Thompson e Wright (2008), as diferenças corporais são um fator dominante nas interações em espaços públicos. Para a autora, a maioria das pessoas não conhece pessoas com nanismo pessoalmente, e suas impressões são formadas a partir do que elas veem na cultura popular. Heider, Scherer e Edlund (2013) sugerem que as percepções culturais a respeito deste grupo populacional são, em grande parte, orientadas pela mídia. Em razão de sua estatura física única, desde 1960 se tem registro de pessoas com nanismo que buscam carreiras na indústria do entretenimento, o que deu origem a representações midiáticas que as expõem ao ridículo e as colocam como objetos de entretenimento. Ainda segundo os autores, nos últimos anos, meios de comunicação produziram programas televisivos que propagam mitos a respeito delas, apresentando pessoas em atividades que não condizem com a vida comum da maioria, como ir ao trabalho por exemplo e nem mostram os desafios que enfrentam na vida e que fazem parte do cotidiano de qualquer pessoa de estatura média. Como esses programas geralmente têm grande alcance, a maioria das representações tradicionais da mídia de pessoas pequenas acabam influenciando as percepções da população em geral.

Em razão disto, estes autores buscaram examinar as percepções de estereótipos culturais e crenças pessoais de indivíduos com estatura média em relação a pessoas com nanismo. Os resultados apontaram que as percepções do estereótipo cultural foram amplamente negativas, incluindo características desagradáveis como estranhas, incapazes e infantis. As únicas qualidades positivas centradas em torno de sua capacidade era entreter outras pessoas, o que, provavelmente, está associado ao fato de muitas vezes estas pessoas serem objetos de ridículo e não à uma apreciação do seu senso de humor. Por outro lado, as crenças pessoais tendiam a incluir qualidades positivas, como capazes, inteligentes e gentis. Quanto às reações afetivas dos participantes da pesquisa a pessoas pequenas, foram de alegria em sua maior parte, além de simpatia, tristeza, nervosismo, afeto, raiva, surpresa, medo. Para os autores, esta sensação de alegria pode derivar da tendência, movida historicamente pela mídia, de ver as pessoas com nanismo como objetos de entretenimento. Isto mostra que a mídia cumpre papel importante em dissipar mitos e estereótipos em relação a esta população. Estas percepções e reações ambivalentes são comuns às relatadas aqui. No Brasil, Chiesse (2014) faz a análise de um programa humorístico que apresenta pessoas com nanismo em papéis estereotipados. Esta discussão será feita mais adiante, ao tratarmos de humilhação e preconceito no trabalho.

Ao tratarem desta identidade popularmente atribuída, os entrevistados descreveram que a falta de conhecimento de outra palavra que substitua o termo "anão" ainda é o motivo 
principal para seu uso. Para eles, dependendo da entonação que uma pessoa emprega ao falar e do contexto em que está sendo utilizado, o seu uso pode ter um sentido pejorativo, ser recebido como ofensa ou apenas como o reconhecimento da categoria social a qual a pessoa com nanismo é localizada aos olhos dos outros.

Pedro: [...] eu tenho vários amigos que é anão. Só que quando chama eles de anão, eles não gostam [...] Mas se a pessoa me chama de anão [...] Se ele me chama com carinho... Porque tem um jeito de chamar com carinho. [...] Porque se a pessoa não sabe o meu nome e vai chamar de anão. E tem gente que chama de anão e na hora pede desculpa: me desculpe eu te chamar de anão. Tem gente que chama de anão na maldade. Aí é diferente, tá? Eu não ligo que chame de anão, não. Desde que seja com respeito e carinho sabe. [...] "Vai seu anão". "Faz isso aí anão". Sabe. É esses dialetos. Que tem gente que usa esse termo. "Falta aquele anão ali". [...] "Manda aquele anão fazer" sabe. Umas coisas mais ou menos assim. Quer dizer, pra isso aí, o anão tem que falar: o meu nome é fulano de tal [...] É porque todo mundo no mundo tem um apelido. Infelizmente. A gente já nascemos com um. Tá. A gente tem nosso nome, mas a gente já nascemos com um nome, que é o anão. Por onde a gente passar, é o anão que vai ali.

Marcela: Antes eu não gostava. Até a minha fase de rejeição eu não gostava nenhum pouco. Eu odiava. Hoje em dia eu já levo mais tranquilo [...] Porque pela entonação da pessoa, como a gente é alvo de preconceito, pela entonação da pessoa a gente consegue perceber se ela tá sendo preconceituosa com a gente, se ela tá atacando a gente, ou se ela tá por curiosidade. É a única informação que ela tem [...] Não conhece outra forma, por não ter tido acesso, então ela acaba usando aquela palavra. Mas é de uma maneira boa. Então dá prá diferenciar. Hoje eu consigo diferenciar de cada pessoa. Então, eu prefiro que não, que não use o termo, mas eu não me incomodo. E antes eu me incomodava muito.

Ricardo: Depende do termo da pessoa, né? Porque tem gente que ele chama prá zoar mesmo com você. Aí depende do jeito, da forma que eles te chamam. Aí eu não fico chateado. Quando eu vejo que é uma pessoa que fala na brincadeira... Que nem tem as criança também que fala: mamãe, ó o anãozinho ali. Eu não vou ficar chateado.

Leonardo: Me incomoda a palavra "anão". Mas porque ela é pejorativa e vem carregada de negatividade ao longo dos anos. Ela é dita de uma forma negativa. Mas eu não acho errado o termo anão, sabe? Eu acho que a pessoa que tem nanismo, ela é anão. Ela é anã. Mas, a forma como ela é dita, a forma como ela foi construída essa palavra ao longo dos anos, incomoda um pouco. Porque é isso, a pessoa não vai falar: o ator [...] que é anão, ou que tem nanismo. Vai falar: o anão [...] e tal e não sei o quê. Então, a palavra vem antes. Ela vem quase como uma identidade sua, sabe? Eles não querem saber quem é [...] É o anão. E depois vem o nome da pessoa. Então, eu acho que ela traz uma responsabilidade muito grande, a palavra "anão". Você constrói toda a imagem da pessoa. Tipo: é o anão. E depois você vai buscar entender quem é essa pessoa, quem é esse ser humano, quem é esse profissional, quem é... seus desejos, as suas vontades, os seus sonhos. Enfim, eu acho que ela vem antes de qualquer coisa. E isso incomoda. É um adjetivo muito pesado, assim, de carregar.

Com sentido pejorativo, a palavra "anão" cumpre uma função de reduzir a identidade de uma pessoa ao estereótipo, a um "traço estático que define o ser" (Ciampa, 2005, p.140), que, conforme a situação, vai incorporando outras formas de predicações. O apelido a que se refere PEDRO, é um exemplo de como a identidade social assume a forma de personagem: “o 
anão". Esta definição cria obstáculos para que outros aspectos da sua personalidade e modo de vida possam ser acessados através de interações. É, portanto, uma identidade rejeitada por todos os entrevistados em razão dos atributos que dão corpo ao estigma em sua identidade social.

Ney: Lembrar que eu sou anão. Isso não. É dramático. [...] Não precisa lembrar. Eu já dou conta. Eu tava na perua, tinha uma senhora que queria estudar comigo e ela perguntou ... tudo o que ela pedia, informação eu dei. No final ela lembrou que eu sou anão. Eu falei: só a senhora que tá lembrando que eu sou anão porque os outros já estão sabendo. É só olhar. Não precisa lembrar.

Joaquim: Se você chegasse prá mim, me conhecesse, tudo e não chamasse eu de anão, não lembrasse que eu tinha nanismo, moça, você era a minha melhor amiga. Só que se você tocasse no caso de anão, sabe? Aí já quebrava aquela confiança.

Para Ablon (1984), a vida com nanismo inclui experiências interpessoais atravessadas por olhares constantes, curiosidade e comentários grosseiros, assim como perguntas das pessoas de estatura média a seu respeito e lembranças explícitas de sua diferença, tal como foi mencionado acima pelos entrevistados. Ablon (1984), Adelson (2005), Ellis (2013) e Kennedy (2003) apontam que, em comparação a outros termos utilizados em outros países para denominar as pessoas com nanismo, o termo "anão" ou "midget", em inglês, é considerado depreciativo e ofensivo. Nos EUA é mais utilizado o termo "pessoa pequena", criado por uma organização denominada Little People of America (LPA). O Canadá também utiliza este termo. No Reino Unido o termo "restricted growth" (RG) ou, em português, "crescimento restrito" é comumente usado. Acompanhando as publicações de associações de pessoas com acondroplasia em redes sociais ao longo desta pesquisa, foi possível observar que na América Latina, há preferência pelo uso de "talla baja", "gente pequena" ou mesmo a denominação clínica mais precisa, acondroplasia, para denominar pessoas de baixa estatura. De todo modo, as pessoas com nanismo têm rejeitado o termo "anão", geralmente atrelado a gnomos e contos de fadas. Estes muitos rótulos demonstram a dificuldade de conciliar rótulos antigos em torno de uma única denominação suficiente para categorizar as pessoas com acondroplasia e demais displasias esqueléticas que provocam baixo crescimento. Como já mencionado anteriormente, neste trabalho escolhemos adotar o termo "pessoas com nanismo".

Pelo exposto, pode-se observar que este processo de reconhecimento da identidade está alinhado às discussões propostas por Ciampa (2005). Para ele, sendo impossível expressar a totalidade de si mesmo, a identidade se expressa empiricamente por meio de personagens sempre quando um indivíduo, como representante de si mesmo, se apresenta 
perante os outros. Do outro, também em exibição, não é possível acessar a sua totalidade enquanto pessoa, o que exige de todos os atores presentes nesta interação a encarnação de um papel previamente padronizado para as interações sociais, tal como uma identidade pressuposta. O problema é que pode haver uma expectativa generalizada de que uma pessoa deva agir permanentemente conforme as predicações da personagem que lhes foi atribuída, deixando-a aprisionada ao que o autor chama de "mesmice", comprometendo a emancipação do indivíduo.

Todos os entrevistados, mesmo os mais jovens, passaram a infância e a juventude sem conhecer e conviver com outras pessoas com nanismo, o que aconteceu apenas na vida adulta, quando as redes sociais na Web começaram a se propagar e as iniciativas para reunir esta população em grupos se efetivaram, encorajando as pessoas a se conectarem a outras. Aliado a isso, começaram a se propagar associações que reúnem pessoas com acondroplasia, a exemplo do que já acontece há mais tempo em outros países, como a Little People of America, nos EUA, e a Fundação ALPE, na Espanha, entre outras.

Ney: Tem pequenos que encontram tu na rua e não conversam, quando não conhece. E aí eu não sei se repele a si mesmo, né? Porque é um espelho. E aí tem que entender o histórico da pessoa. Sabe, passa, correndo! Ai, tomara que eu não veja, tomara que eu não veja.

Marcela: Muitas pessoas com nanismo também não têm esse contato, ainda não conhece ninguém, às vezes vive a sua rotina ali, não conhece ninguém com nanismo [...] Que eu passei a encontrar? Foi naquele encontro em Atibaia. A primeira vez que eu encontrei... [...] Então, com dezoito anos eu não tinha procurado nada. Aí bateu aquela dúvida [...] Eu sabia o que eu tinha. Sempre soube o que eu tinha. Sempre soube que haviam pessoas iguais a mim. A gente acabava se esbarrando em shopping, em parque, não sei o quê, mas tipo, a gente não chega a ter um contato. [...] Aí, com dezoito anos eu resolvi por exemplo, deixar as explicações dos meus pais de lado e eu mesma procurar [...] Aí, alguém me adicionou no Facebook [...] Aí eu soube [...] um evento que ia ter em março daquele ano. Ia ser um encontro [...] Mas eu senti que eu não tava pronta ainda. Nossa, conhecer um monte de pequeno. Eu nunca conversei com nenhum. Tinha um monte de gente. Eu falei: não tô pronta ainda. [...] Passei a procurar, passei a procurar cada vez mais pessoas. [...] Aí eu pensei: por que não? [...] Aí eu fui. Nossa, foi um baque, que eu nunca tinha visto nada a ver. Todo mundo aqui assim. É diferente. [...] Foi bom. Foi tipo uma sensação estranha e boa ao mesmo tempo. Estranha porque eu nunca vi, nunca, tipo, vi que todos eram iguais a mim ou até antes, o receio que eu até eu tinha preconceito contra mim mesma. Aí, eu vi que abriu a minha mente conhecer todas essas pessoas e tudo o mais. Aí lá eu consegui algumas amizades que eu levo até hoje.

Para Ablon (1984), o "efeito espelho" ocorre quando um indivíduo experimenta um grande choque ao encontrar pessoas de estatura semelhante, uma vez que isso funciona como um lembrete a respeito de sua própria aparência. Ablon $(1984,2002)$ sugere que as associações de pessoas com nanismo podem ajudar a lidar com esta negação da baixa estatura a partir dos exemplos de outros membros da organização, que tem empregos e famílias 
constituídas, auxiliando na aceitação de sua condição e na formação de um ideal de vida comum. Pelo que foi narrado pela entrevistada acima, parece ter sido valiosa a experiência da entrevistada de conhecer outras pessoas em igual condição à sua. Segundo Major e O'Brien (2005), os membros de grupos estigmatizados podem lidar com ameaças à sua identidade aproximando-se ou identificando-se com o seu respectivo grupo, o qual pode fornecer apoio emocional, informativo, instrumental, consenso social para as atribuições e um sentimento de pertencimento, fatores correlacionados com a autoestima.

Nesse processo de estigmatização, as respostas sociais à presença de uma pessoa com nanismo em público são bastante variadas e até contraditórias. Sua presença na cena pública desperta atenção, olhares curiosos, assédio e infantilização e provocações (Adelson, 2005b, 2005c; Ellis, 2018; Shakespeare, Thompson, \& Wright 2007, 2010), deixando-lhes a sensação de estarem sendo observados constantemente, tornando difícil circular sob o anonimato de pessoa comum. As reações empreendidas pelos outros depende muito do que é associado à sua identidade social. Como aponta Hughes (1999), a visão é uma prática social fundada num regime ocular produzido culturalmente. Ao objetivar o que é captado, o olhar entra no jogo da intercorporeidade e intersubjetividade das relações sociais, podendo se tornar profundamente hostil e opressivo a quem está sujeito a ele, como alvo de uma supervisão tirana que compromete a liberdade de quem é olhado. Para o autor, o olhar é um ato profundamente cultural, que incorpora e deixa transbordar interpretação e julgamento, constitutivo de relações sociais e culturais que reproduzem formas de opressão, discriminação e exclusão. Segundo Bodgan (1988, p. 10), "a maneira como vemos pessoas diferentes tem menos a ver com o que são fisiologicamente do que com quem são culturalmente".

Marcela: Hoje em dia, prá sair é tudo tranquilo. As pessoas olham, claro, normal. [...] Todo mundo olha, ainda mais se eu tô vestida de uma maneira mais social, mais arrumadinha, que dá pra aparecer que sou uma pessoa adulta. [...] E tenho amigos também com nanismo. Aí quando a gente sai, aí chama muito mais atenção. [...] A gente já saiu, todo mundo junto, num shopping. Chama muito atenção. Todo mundo para prá olhar. Ou tira foto. Às vezes, a gente não gosta muito que tira foto porque ali, a foto a gente sabe que não vai ser usada pra bons fins, né? Tirar chacota. [...] Mas também já ouvi casos de pessoas que tem traumas, que realmente tem medo. Não chega perto. Já ouvi um caso de um amigo [...] que tava sentado numa mesa comendo e tinha uma mulher do lado dele com um cara. [...] Ela pediu pro garçom pra mudar de mesa pra não sentar perto dele.

Joaquim: Porque a pior coisa na vida é você se sentir incomodado, sabe? É você não poder andar na rua. [...] Aquela coisa engraçadinha... [...] Tem gente que tem medo de nanismo, de pessoa que tem nanismo [...]. Prá você ver, aqui em São Paulo [...] quando chega perto: oh, o anão! A mãe cutuca: olha lá filha, olha, olha [...] só queremos [...] Entrar num restaurante normal, almoçar, tudo, ser atendido com educação, sem piadinha [...] Tem gente que, às vezes, nem conhece a minha esposa e já brinca assim de uma maneira, sabe? Com coisa como se ela fosse uma criança [...] porque as pessoas ainda não encararam a gente, ainda não conseguiram 
assimilar nós como uma pessoa, digamos assim como uma pessoa da sociedade. [...] uma pessoa comum.

Leonardo: Então, tem vários olhares. Tem o olhar de dó, de pena, que me incomoda muito, que é de: você não é capaz de fazer isso; ah, deixa eu te ajudar. [...] Mas essa: ai, tadinho. Isso me incomoda. É um olhar que me incomoda. Tem o olhar de: ha, o anão! Olha lá que engraçado. Que é dia a dia. [...] E isso me incomodava muito, o olhar do cômico. Tem o olhar de dó, vitimização... acho que é o igual. Não sei... Tem vários olhares, assim, que ao longo da vida, você vai percebendo [...] Ao longo da vida você percebe, você sabe lidar com os diferentes olhares.

A ambivalência de reações afetivas a pessoas pequenas descritas por Heider, Scherer e Edlund (2013), que incluíam alegria e tristeza, simpatia e nervosismo, afeto e raiva, medo e entusiasmo, indicam que as atitudes gerais em relação a esta população são caracterizadas pela ambivalência. As experiências de serem observados o tempo todo, as provocações e o assédio do público em geral continuam a fazer parte do cotidiano delas, e, como apontam Skakespeare, Thompson e Wright (2007), é impossível escapar da curiosidade e, ocasionalmente, da hostilidade de pessoas sem deficiência.

Ellis $(2013$, 2018), ao estudar como o crescimento restrito influencia nas interações sociais de pessoas com nanismo em espaços públicos, ressalta que a experiência mais difundida e comum a todos os participantes foi o olhar fixo de que eram alvo. Alguns interpretaram este olhar como um lembrete constante da sua diferença em relação às demais pessoas. Segundo Reeve (2002), o olhar exerce poder sobre as pessoas com deficiência no cotidiano das interações sociais. Influenciado pelos estereótipos e preconceitos, ele é nutrido pelo conhecimento construído em âmbito social e opera nos corpos com deficiência de maneira a fazer com que se sintam envergonhadas, vulneráveis, inválidas, o que se localiza na dimensão psicoemocional ${ }^{7}$ da deficiência.

Sobre a tomada de fotos sem autorização, não é uma preocupação solitária de Marcela. Estudos de Ellis (2018) apontaram que muitas pessoas com nanismo ficam surpresas ao se depararem com fotos de seus amigos ou de si mesmo na Web, sem sua aprovação, usadas em imagens legendadas em tons de zombaria. O olhar marcador da diferença e o seu prolongamento pelo registro fotográfico fortalece a experiência de pessoas com nanismo serem consideradas como estranhas nos espaços públicos. Nos estudos de Kruse (2003), mulheres com nanismo também apontaram que suas experiências em espaços públicos são

\footnotetext{
${ }^{7}$ Dimensões psicoemocionais da deficiência: afetam o que as pessoas com deficiência podem ser, em vez do que podem fazer, incluem ser feridas pelas reações de outras pessoas, sentir-se sem valor e sem atrativos e ter suas raízes nas atitudes e preconceitos negativos sobre pessoas com deficiência dentro da sociedade (Reeve, 2002, p. 495).
} 
intensificadas pelos olhares diários das pessoas, que parecem atraídas por suas aparições incomuns. Para o autor, as respostas de hostilidade ou curiosidade a pessoas pequenas em espaços públicos podem resultar da percepção de que elas não pertencem aos espaços da vida cotidiana de muitos adultos.

\subsubsection{Reações da pessoa com nanismo à estigmatização}

Para Ablon (2002), o modo como os indivíduos estigmatizados lidam com os insultos diários colocam em risco sua identidade pessoal, a vida pessoal e as oportunidades econômicas. Ao longo das entrevistas, as pessoas narraram algumas ações empreendidas em resposta ao tratamento que lhes é dispensado publicamente. De respostas mais agressivas a diálogos com propósito esclarecedores a respeito de seu atributo diferencial fazem parte da rotina cotidiana de todos eles.

Ney: [...] minha mãe dizia [...] eu tacava pedra nas pessoas. Não é engraçado. É bizarro, né? Isso é horrível. [...] Tem discussões de grupos que, por exemplo, na época do Pânico, eu tava jantando com a minha namorada na época, que também é anã, e um cara veio bater na minha nuca, né? Tipo pedala Robinho, aí eu falei: do mesmo jeito que você acertou a minha nuca eu acerto esse garfo no seu olho só de jogar, porque pontaria eu tenho.

Pedro: Eu tento ser educado entendeu. [...] Tem gente que diz: eita bicho feio, que anão feio. [...] Aí, quando eu tô embaçado, eu xingo a pessoa. [...] tem palavras que machuca, né? [...] Quantas vezes eu não passei por aí, por a rua, e o pessoal fica batendo uma na outra dizendo: aonde vai um anão. E apontando.

Nos relatos foram frequentes citações a respeito de fotos que são registradas no espaço público sem sua autorização, o que motiva diferentes reações, tais como o enfrentamento, com ameaças de processo a quem fotografa, busca de esconderijos para evitar ser fotografado, até se deixar fotografar, ignorando a situação.

Marcela: Amigos meus, tipo, quando vai tirar foto, ficam muito bravos. A pessoa, às vezes... (riso) um amigo meu, às vezes, tira foto da pessoa e fala que vai processar. Fala: se você não deletar, eu posso te processar por direitos de imagem; eu não gosto, eu vou ficar bravo. Mas eu sou mais tranquila. Assim, eu evito, eu evito, mas também não ligo ao mesmo tempo. Finjo, finjo que não ligo. A gente olha? A gente olha, as pessoas olhando.

Joaquim: Ou risada, ou agora a pessoa tá na onda de tirar foto, sabe? Imagina só, você na rua e a pessoa vai lá e tira foto. Você não vai achar ruim? Então. O mesmo direito que você tem de achar ruim, eu também tenho. Por que que a pessoa tira foto? [...] A gente sabe que tá rindo da gente. Não precisa da pessoa inventar. A gente sabe que aquela outra pessoa que tá lá atrás tá tirando foto da gente. [...] Então, mas eu vou fazer o quê? Às vezes, quando eu vejo a pessoa que tá no celular, porque a pessoa disfarça, né? Eu vou lá e escondo atrás de uma pessoa [...] A pessoa fica lá esperando. Eu falo: eu não vou sair... A pessoa fica andando. Aí eu escondo 
atrás do poste. Aí a pessoa: cadê ele? [...] Eu acho uma falta de respeito, sabe? Tem gente que filma a gente. [...] que você é engraçadinho. Engraçado, por quê? Eu tô fazendo alguma graça pra você? Nem te conheço, nem nada. Engraçadinho, por quê, né? As pessoas não têm noção.

Leonardo: Constante, no transporte público, na vida. As pessoas tentando tirar foto sua, escondida. Que isso é um absurdo. Isso me incomodava muito, no trem, quando eu estudava na zona Norte de São Paulo e morava em Osasco. Então eu pegava metrô, ônibus e trem. E aí no trem sempre tinha alguém que tava com o celularzinho assim, tentando tirar foto. Aí você olha pra pessoa, ela abaixa. Não sabe nem disfarçar, né?

Tal como descrito acima, estudos conduzidos por Ellis $(2013$, 2018) revelaram o que pessoas com nanismo experimentam em situações onde estranhos tiram fotos não autorizadas deles nos espaços públicos. Este fenômeno é relativamente novo, ganhando notoriedade com a proliferação do uso de câmeras portáteis (Ellis, 2018; Shakespeare, Thompson, \& Wright 2007, 2010) denotando um desejo de um olhar prolongado para além de um olhar inicial (Shakespeare, 2003). Em Kennedy (2003), alguns participantes relataram que a experiência de tomadas de fotos não autorizadas reflete visões específicas a respeito de seus corpos e uma crença social e cultural de que eles são para exibição pública. A mensagem, em todos os casos, parece reforçar o olhar social a respeito de seu corpo, categorizado como bizarro, anormal e permanentemente disponível para exposição. Como frequentemente são alvos das lentes alheias, as pessoas com nanismo também encontram formas de escapar à esta situação. De acordo com o relato acima, muitas aprendem a manipular o olhar do outro, quando se escondem e invertem os papéis de serem olhadas e vigiadas.

Também é comum evitarem locais de grande concentração de pessoas, sobretudo crianças, para escaparem de olhares e perguntas delas aos adultos que as acompanham, o que inevitavelmente trará à tona comentários que podem ser pejorativos ou que não correspondem à realidade da sua identidade. Ellis (2013) também encontrou resultados similares em sua pesquisa, quando participantes declararam evitar certos espaços públicos nos quais, por experiência ou por um sentimento instintivo, eles previam um tratamento discriminatório. Para Major e O’Brien (2005), quando uma identidade social é consensualmente desvalorizada, aumenta a exposição a situações potencialmente estressantes, que ameaçam a identidade do indivíduo estigmatizado. Cientes do estereótipo, estas situações que colocam a pessoa em risco de sofrer ameaças à sua identidade social, são evitadas, pois excedem os limites para lidar com suas demandas, conforme relatado a seguir:

Joaquim: Você sabe qual o meu medo hoje, que a gente ainda evita? É quando assim, tem alguma criança [...] ou no metrô, alguma coisa assim, a gente evita de ficar... Se a gente puder ir mais prá um cantinho, sabe? Porque a gente não quer aquela coisa: oh, o anão. Aí a mãe: olha filho, é do seu tamanho. [...] É que a gente, às vezes, naquele dia você não quer... Você 
quer ficar sossegado, você quer andar sossegado, você entendeu? [...] Não é que eu fujo, nem nada, da realidade. Às vezes, a gente já tá cansado e, às vezes, eu não quero responder sabe, mal, não quero ter nervoso. Porque aquilo lá acaba com o seu dia. Mas tem dia que a gente não aguenta. Tem dia que a gente tem que, infelizmente, a gente num... Às vezes, você vai num shopping, granfino, shopping lá que só tem mulheres informadas, tudo. - Olha lá filha, olha filha, olha lá o anão, é do seu tamanho. Principalmente com essa coisa: é do seu tamanho.

Como sempre conviveram com os olhares invasivos, e comentários que desvalorizam sua identidade, os entrevistados também relataram que aprenderam a ignorar as provocações.

João: Eu falei: Meu, quer me xingar, xinga, quer me zoar, me zoa, porque no país a gente não tem uma lei que intimide as pessoas a realmente a fazerem isso.

Marcela: Assim, eu evito, eu evito, mas também não ligo ao mesmo tempo. Finjo, finjo que não ligo. A gente olha? A gente olha, as pessoas olhando. Isso aí sempre olham. Mas, a maioria das vezes a gente tenta ignorar. [...] Olhares sempre tem. [...] Criança para e olha muito mais. Às vezes, chega uma criança e fica assim: parada, olhando assim. Mas eu sempre ignoro. Mas se tipo a criança... dá prá perceber a inocência da criança. Se ela tá parada, se ela tá olhando, é porque ela: nossa, alguém diferente, alguém novo, eu nunca vi uma pessoa assim. Aí eu até rio prá criança e, às vezes, se a mãe é tranquila, eu sempre sou gentil e tudo o mais. Aí, às vezes, também tem casos que os pais disfarçam, que não tem conhecimento, que tem medo. Eu nunca vi criança, em si, com medo. São os pais que...

Leonardo: A criança sabe. Talvez, ela tenha a curiosidade, de primeiro impacto de: nossa, um cara da minha idade de barba! Acontece muito isso. E aí ela vai perguntar pro pai. E aí o pai vai e recrimina. [...] Então, os pais têm medo de ofender a gente, de explicar e ofender a gente, mas aí recrimina a criança. E aí a criança cresce com aquilo de: eu não posso olhar, eu não posso falar, é diferente, é estranho. [...] Sem poder falar sobre isso. Ou uma explicação errada, sabe? Também o pai vira e fala: ah, não tem a Branca de Neve e os Sete Anões? Aí você fala: putz, a pessoa vai me enxergar como um ser da fantasia pro resto da vida, né? Não é real. É um ser mágico que existe somente em contos de fadas.

A provocação curiosa de crianças a seus pais quando encontram uma pessoa com nanismo foi muito mencionada pelos entrevistados. Na opinião deles, os pais demonstram não saber lidar com a situação de explicar as diferenças entre as pessoas e recorrem a explicações e exemplificações que remetem ao estereótipo dos contos infantis ou repreendem os filhos que, muito mais por curiosidade do que por hostilidade, expressam surpresa ao ver uma pessoa pequena. Kruse (2003) assinala que uma reação exagerada dos pais pode contribuir para a percepção da criança de que pessoas com corpos incomuns são estranhas, o que influencia a socialização dela em relação às aparências e comportamento dos outros. Para ele, as primeiras referências que uma criança tem a respeito de pessoas pequenas geralmente incluem contos de fadas e filmes como o "Mágico de Oz". Pessoas pequenas em espaços 
públicos podem confundir os limites entre o que é real e o que é imaginário na mente da criança, como exemplificado abaixo:

Pedro: Outro dia eu ia trabalhar, aí sempre passava em frente da casa de um cara. Aí tinha uma menininha, né? Deste tamanhinha [...] a menininha quando me via que eu passava, dizia: pai, compra aquele hominho prá mim. Só tu vendo sabe. E ficava chorando, chorando, pro pai comprar aquele hominho prá mim. Compra aquele hominho, ela falava. Aí ela achava engraçado, porque é criança meu. Criança é inocente. E umas coisas assim que eu ficava olhando meu... Não acredito. Umas coisas que acontece sabe. Que acontece com a gente que é anão. É cada coisa que é fora do normal.

Segundo Shakespeare (2003), como o crescimento restrito ainda é considerado raro, parece que as pessoas nunca vão superar sua curiosidade sobre os anões. Para ele, uma das barreiras sociais enfrentadas no cotidiano, são o olhar ininterrupto, não apenas de crianças, mas também as perguntas intrusivas de adultos que acham essa prática completamente aceitável.

Para alguém que tem uma diferença física que é alvo da estigmatização, são muitos os sentimentos reativos às situações de um cotidiano que a impedem de se sentir uma pessoa comum, dentre tantas outras. Desesperança, dificuldade para aceitar a si mesmo, foram alguns dos sentimentos descritos.

João: Daí era um vazio que bate [...] é algo que bate em você e você entra em desespero. [...] É difícil. Você não é ninguém. Você não é ninguém. [...] O preconceito, ele vem, o preconceito vem nos seus olhos, vem na sua boca, vem no seu corpo. Ele existe. Ele vai existir comigo pro resto da vida. [...] Porque assim, não é fácil, não é fácil. Você ser discriminado, você ter a diferença social, você não ser aceito. Porque não é aceito, você entendeu. E às vezes, em muitas situações, eu mesmo não me aceitava. Eu falava: meu, essa vida não é prá mim.

Outro sentimento bastante descrito foi a vergonha sentida ao estar na companhia de pessoas de considerável valor afetivo. Mediante comentários e gestos depreciativos, estes entes queridos saíam em sua defesa ou relatavam sentimentos de raiva em razão do ocorrido, o que contribuía para aumentar a vergonha sentida. O desejo manifesto nos relatos é que a pessoa jamais anotasse verbalmente o que se passava ao redor, ignorando também os incidentes. Embora muitos entrevistados descrevam estes sentimentos como vergonha, eles também parecem incorporar o sentimento de humilhação, visto que há tanto o sentimento de inadequação aos olhos dos outros, que realmente é nomeado como vergonha, como também o sentimento de degradação, ridicularização e desprezo, não pelo que fez, mas pelo que é, constituindo-se como um ataque à sua identidade e denominado de humilhação (Hartling \& Luchetta, 1999; Klein, 1991, 2004; Neuhäuser, 2010). Goffman (2012) ressalta que a internalização dos padrões que o indivíduo incorpora da sociedade contribuem para que ele se 
sinta suscetível ao que os outros veem como seu defeito e a concordar, em alguns momentos, que está abaixo do que realmente deveria ser.

Ney: Minha irmã [...] Se ela vê uma criança ou alguém, adolescente, olhando pra mim, ela repara que a pessoa tá reparando, ao invés dela, de repente, fazer o que eu faço, ou ignorar, ou conversar. O que é? Nunca viu não? Só porque ele é pequeno? Ele é pequeno, e daí? Então nem ando muito com ela, não, porque ela vai lembrar prá pessoa que já tá com preconceito quem eu sou...

Marcela: O meu pai já não gosta. Ele fica bravo. Quando eu andei de metrô com ele a última vez [...] Aí eu tava super tranquila, se alguém falava alguma coisa... Criança aponta muito fácil. Ele ficava bravo e depois ele falava: nossa, não aguento isso. Eu falava: calma, relaxa, disfarça.

Joaquim: [...] A gente quer ter a liberdade. Porque é ruim. Às vezes, antigamente, eu sentia até vergonha de andar, tipo assim, com você, faz de conta. Os outros tiravam sarro. Eu me sentia vergonha perante à você sabe. Eu falava: ai meu Deus do céu. É por isso que eu me escondia. É por isso que eu gostava de andar sozinho. Devido a isso. Porque eu não queria passar essa imagem do jeito que eu sou visto na rua, tudo, sabe. [...] Eu tinha uma vergonha dos cambau, meu. Eu ficava assim, eu falava: ai meu Deus do céu, tomara que... [...] eu tô lá com a [...] andando na rua né, e aí eu faço de tudo pra disfarçar, e você fala pra mim: você viu aquela pessoa lá tirou sarro de você, você andando, tudo, ai meu Deus, sabe? Aí eu falo: não, eu vi, não precisa você... [...] não precisa ficar lembrando a gente que a gente é anão...[...] A gente sabe que tá rindo da gente [...] A gente sabe que aquela outra pessoa que tá lá atrás tá tirando foto da gente. Meu, a gente já tá tão acostumado.

Leonardo: A pessoa de estatura média, ela vai sofrer por ter escolhido aquele parceiro, por ter se apaixonado por aquele parceiro, ao que ela nunca sofreu. Algo que ela não tá acostumada. Eu acho que é muito mais... afeta muito mais a pessoa de estatura média do que a pessoa com nanismo. A pessoa com nanismo já tá acostumada com esse tipo de preconceito, né? Eu digo isso porque eu sempre me relacionei com mulheres de estatura média [...] E eu lembro que eu tive uma namorada que ela tinha um problema, assim, de... ela queria arrumar briga com as pessoas. A gente estava no dia a dia, às vezes, andando de mão dada ou, sei lá, no transporte público e ela ficava encarando as pessoas que estavam olhando. Quê que foi? Qual o problema? Entende... Prá ela era mais difícil do que pra mim. Eu falava: não, relaxa, deixa, tá tranquilo, tal. Então eu acho que é muito mais ofensivo, ou machuca muito mais a pessoa... [...] machucava mais quem tava em meu redor, tipo os meus pais, e isso me doía mais, de machucar eles, do que propriamente o olhar da pessoa em mim. Se eu tivesse sozinho na rua e recebesse um olhar, prá mim, eu acho que era um pouco mais tranquilo do que se eu tivesse com a minha mãe e eu perceber a minha mãe incomodada com o olhar de outra pessoa, sabe? Acho que me machucava mais a reação da minha mãe incomodada, tipo, do que eu propriamente dito.

Para Goffman (2012), a consciência de apresentar num espaço público uma diferença considerada exótica, rara, que suscita gestos sociais e comentários de menosprezo, pode levar o indivíduo a enfrentar ambivalência em relação ao próprio eu, como sentimentos de vergonha, insegurança, ansiedade, medo de não ser aceito e respeitado pelos outros, comprometendo sua percepção a respeito de como as outras pessoas irão ser receptivas à sua presença, o que afeta o seu bem-estar psicológico. 
Ablon (1990) acrescenta que as pessoas com nanismo ainda precisam lidar com o gerenciamento das atitudes imprecisas de outras pessoas ao serem encaradas em locais públicos. Segundo os relatos acima, além deste gerenciamento relacionado aos olhares e comentários dos passantes, há necessidade também do gerenciamento das situações nas quais se está na presença de pessoas de considerável valor afetivo, as quais, no intuito de defendêla, respondem à estas formas de violência. Se as pessoas com nanismo vão se "acostumando" ao longo da vida a estas formas de agressão, quem as acompanha, não. Na descrição dos entrevistados, em vez de se sentirem protegidos por atitudes em sua defesa, eles têm o sentimento de vergonha e humilhação aumentados pela exposição à esta forma de rebaixamento social.

Se "acostumar" com as reações dos outros, ao tipo de visibilidade que provocam, foi relatado por todos os entrevistados. Relatos como estes remetem ao que Goffman (2012) descreve como construção da imagem de si por parte de pessoas estigmatizadas. Para ele, esta imagem é construída utilizando o mesmo material que as outras pessoas utilizam para considerar sua identidade social, ainda que tenha formas de elaborar de diferentes maneiras.

Pedro: Eu aceito. Eu aceito, porque infelizmente eu sou diferente, né? Sou um ser humano igual a todos, mas altura, menor. Eu tenho um metro de doze de altura. Por onde eu passar, eu vou chamar a atenção. O tamanho da gente chama a atenção. Aí tem muita gente que fica incomodada, mas eu falo prá vocês: não fique incomodada não. Sabe por quê? Porque nós nascemos diferente.

O período em que a diferença parece despertar maior desconforto social para a própria pessoa afetada parece ser na adolescência. Vários entrevistados falaram desse período como o mais problemático, em que sua imagem em relação aos seus pares tornaram mais intensos os sentimentos de rejeição, não aceitação de si, revolta.

Leonardo: Porque a pessoa com nanismo recebe olhares a vida inteira. Ela vai se acostumando, né? O que é ruim. Mas vai se acostumando com esses olhares, com esse preconceito do dia a dia. [...] Porque é algo que virou comum prá mim. Assim, tipo, não me afeta hoje. Tanto. Não me afeta tanto. Acho que na infância me incomodava bastante. Na infância barra adolescência. Acho que adolescência, principalmente, me incomodava bastante. Adolescência é um período complicado, né? Prá todos. De aceitação, de mudança de hormônios, de se adequar, se padronizar o que querem e aí você ser diferente, acho que era mais agressivo prá mim, assim, ser olhado, ser apontado, risadas. [...] Não, não ligo. Não vou dizer que não incomoda. Tem algum lugar lá no fundo ainda incomoda quando você percebe que é um olhar maldoso, um olhar discriminatório. Quando você percebe que é um olhar discriminatório ainda machuca em algum lugar lá no fundo, mas muito menos. Muito menos. Porque é isso. A vida inteira você vai se acostumando, você vai criando camadas, você vai criando escudo, você vai criando... 
Para Ablon (1984) e Thompson, Shakespeare e Wright (2008), a adolescência é um período difícil para todos os jovens, quando emergem questões de identidade, independência e papéis futuros de adultos. Mas para os que possuem displasias esqueléticas, esse período pode ser mais estressante por se sentirem menos aceitos pelos colegas, menos propensos a ingressar em atividades sociais e mais dependentes da família em um momento em que os colegas estão tentando fazer exatamente o contrário. Siegel, Clopper e Stabler (1991) apontam que neste período muitos já não são mais capazes de competir socialmente ou em esportes com seus pares de idade, o que pode encorajar sentimentos negativos sobre a própria estatura e até mesmo a retirada social gradual em direção ao isolamento.

\subsubsection{Humilhação}

O estereótipo em torno da pessoa com nanismo, construído ao longo de séculos, ainda produz consequências nos dias atuais. Seu atributo diferencial recebe grande visibilidade social, nem sempre receptiva. As reações engajadas em sua presença produzem impactos na esfera emocional destas pessoas, pois desvalorizam sua identidade, ferem sua dignidade e respeito enquanto pessoa humana. Olhares, comentários pejorativos, risos, tomadas de fotos sem autorização, discriminação, são direcionados a elas sem encontrar resistência de expectadores, deixando-a em posição de baixa valoração social. Entre os entrevistados, são comuns sentimentos de desamparo, raiva, de diminuição do seu valor social pelos outros, desprezo, assim como descreve Klein (1991) e Gonçalves Filho (2007) ao tratarem da humilhação.

Para Honneth (2003), na descrição daquelas pessoas que se veem maltratadas por outras, predominam as categorias morais de ofensa e rebaixamento, o que constituem formas de desrespeito ou de reconhecimento recusado. Para ele, comportamentos assim designados representam uma injustiça não só porque prejudicam e tolhem a liberdade de ação dos sujeitos, causando-lhes danos, mas também porque ferem a autorrelação positiva que as pessoas construíram a respeito de si mesmas de forma intersubjetiva. Sob a denominação de “desrespeito" ou “ofensa", essas ações podem provocar lesões profundas ao psiquismo de um sujeito.

João: Você passar na rua e falarem: oh, bunda de tanajura, sua bunda rela no chão, que nem aquela formiga. Ou: oh, anão, perna curta ou braço curto. [...] Eu peguei um ônibus, sentei do lado de uma mulher e essa mulher ela tava tirando foto minha e tirando sarro e passando por WhatsApp. Oh, o pé dele no chão. Oh, ele tá gordo. Oh, a cabeça dele [...] Quando eu vi ela 
passando duas fotos minhas e cácácácácá [ela ria], eu fui perguntar, eu questionei: Por que que a senhora tá fazendo isso? Ela falou: não te interessa.

Ney: O olhar, todo mundo ... cutuca, olha... tem n situações. Tem religiosos que me encontram na rua e quando me percebe começa a orar alto. Quando são tímidos. Quando eles não são tímidos eles olham, se aproximam: Jesus te ama, tá? Acredite! Tem pais: filho, vem ver, vem ver, vem ver, filha, filha, filha, corre, corre aqui, filha, vem ver.

Pedro: [...] de muita gente na rua. Tem gente que diz: eita bicho feio, que anão feio. [...] Aí eu sentei ali no metrô [...] Aí a menina quando me viu, começou a gritar e a chorar. E eu fiquei lá, sentado. Aí a mãe dela olhou prá mim [...] e disse: você é doido, você é besta, seu idiota. Você não tá vendo que a menina tá com medo de você? Ave maria, aquilo ali...

Joaquim: Eu me sinto humilhado, eu me sinto uma pessoa diferente. Não é uma pessoa. É um bicho qualquer que provoca reações nas pessoas, sabe? Não é nem como pessoa.

Leonardo: [...] talvez na infância e na adolescência fosse um olhar de reprovação, de pena, de dó, de várias formas que machucavam, que era agressivo.

Estas experiências de humilhação social vivenciadas por eles podem se constituir como barreiras psicológicas para o convívio social. O medo de ser humilhado pode leva-las a viver sob ostracismo. De acordo com Klein (1991, 2004), sentir-se vulnerável à humilhação, independentemente de experiências anteriores, faz com que a pessoa desenvolva o desejo de tentar escapar dela a todo custo. Como assinalaram os participantes da pesquisa de Reeve (2002), não são apenas as limitações físicas que restringem as pessoas com deficiência ao ambiente doméstico e ao convívio daqueles que já as conhecem. Devem estar aí incluídas a experiência de entrada no mundo público, de ter sua deficiência exposta às reações dos observadores, muitas vezes hostis, de piedade, e, no caso de pessoas com nanismo, de risos, medo e comentários jocosos.

Marcela: Tem gente que tem medo, tem pavor de gente apontando na rua, de quando é abordado pelo preconceito. Não gosta e fica trancado dentro de casa. [...] Tem gente que afeta. Acho que há tanto casos em que há a superproteção familiar, quanto há casos em que a pessoa se rejeita a enfrentar o mundo lá fora. Então acho isso também impede que a gente veja mais pequenos por aí. Por isso que muita gente acaba ficando dentro de casa, trabalhando em casa, com tarefas domésticas e, muitas vezes, dependente de outra pessoa.

O ostracismo não é apenas uma reação da pessoa com nanismo, podendo partir da própria família o desejo de esconder a informação de que um dos seus membros tem esta deficiência.

Joaquim: Que nem na minha infância, digamos assim, meus irmãos aceitava [...] Só que às vezes as pessoas tiravam tanto sarro que teve uma época que meu irmão, sem maldade, falou assim: se eu fosse você, ficava mais preso em casa. Teve uma situação também da minha irmã, que trabalhava numa grande empresa, né? [...] conheci duas mocinhas [...] Aí, papo vai e papo 
vem, descobri aonde que elas trabalhavam na mesma empresa que a minha irmã trabalhava [...] Meu, mas aí no outro dia a minha irmã chegou desesperada em casa e falou: Por que que você falou que eu era sua irmã? [...] Porque essas duas meninas contaram prá todo mundo que minha irmã tinha um irmão anão. Meu, imagina, ela ficou tão desesperada que ela falou que não conseguia nem almoçar sabe, no dia.

Para Goffman (2012), este comportamento se relaciona ao caráter da informação social transmitida quando se tem um relacionamento com alguém estigmatizado. Em algumas situações, a identidade social do estigmatizado pode ser usada como "fonte de informação sobre a própria identidade social, supondo-se que ele é o que os outros são" (p.57). Por essa razão, as pessoas podem manipular as informações que são transmitidas a respeito de si mesmas ao tentarem omitir relações com a pessoa com nanismo.

\subsection{As consequências da estigmatização de pessoas com nanismo na esfera do trabalho}

A seguir, serão apresentados os resultados e reflexões acerca do processo de estigmatização na esfera do trabalho, reunidos em torno do "Vida de trabalho",

\subsubsection{Vida de Trabalho}

Sob este tema, foram reunidos cinco subtemas. São eles: dificuldades de inserção no mercado de trabalho, trabalho desprotegido, influência do estereótipo nas oportunidades de trabalho, lei de cotas, humilhação e preconceito no trabalho. Separadamente, os dados e reflexões referentes a eles serão apresentados a seguir.

\subsubsection{Dificuldades de inserção no mercado de trabalho}

O processo de planejamento para a entrada no mercado de trabalho geralmente se dá muito antes da chegada do jovem à vida adulta. A construção da trajetória de vida de trabalho ocorre ao longo do processo de socialização e recebe a influência de aspectos sociais, culturais, econômicos, de saúde, identitários, que integram a estruturação de um projeto de vida de trabalho. Mas a situação de vulnerabilidade e dificuldade de reconhecimento sociais podem comprometer a construção deste projeto e, consequentemente, afetar as dimensões psicológica, psicossocial e socioeconômica que, segundo Ribeiro (2014), são constituintes do 
trabalho. Para as pessoas com nanismo, que precisaram lidar desde cedo com reações sociais negativas à sua imagem, que pouco ou nenhum contato tiveram com os seus iguais para construírem referenciais de apoio e inspiração no mundo do trabalho, tendo acesso apenas à representação de si de forma caricata, as expectativas profissionais se mostraram negativas para a maioria. A autoestima, já tão abalada por vivências de interação social causadoras de sofrimento, também afeta o quadro de perspectivas futuras de direito ao trabalho, quando a busca por um emprego encontra um "não" como resposta, repetido por muitas vezes, a ponto de levar ao desalento aquele que busca uma inserção laboral.

João: Eu não tinha pretensão de fazer nada. Nada.

Ney: Em 1989 você vai procurar trabalho e você leva um não que você já tinha. [...] Pelo preconceito. Não era uma coisa como hoje, de aceitação, de cota. Então as empresas diziam não e não e não. E olha que eu fiz curso de auxiliar de escritório na época. [...] É da conquista. Como eu dei aula trinta anos, eu sempre me imaginava indo de manhã para um trabalho. Olha que louco. Porque tu vê todo mundo indo, né? E você trabalha no bairro.

Joaquim: [...] o meu sonho era de ver a minha carteira registrada. Mostrar... Eu queria ser igual aos meus irmãos, assim, trabalhar [...] ter a carteira registrada, chegar cansado sabe, falar: graças a Deus hoje eu trabalhei [...] você fica naquela, assim, de tanto espera, de tanto você levar não, né? [...] eu queria mostrar pra sociedade coisa que eu não era prá trabalhar em circo, prá trabalhar em fazer evento [...] Não é orgulho. É que aquilo doía muito.

Pelos depoimentos é possível observar que foi comum aos entrevistados um pretérito de desesperança, do direito ao trabalho negado, da vontade de ser aceito e reconhecido como um cidadão de igual valor social. Para eles, o projeto de trabalho estava menos relacionado à questão econômica, ao sentir-se útil e produtivo, e mais direcionado à uma expectativa de sentir-se igual, de ser inscrito socialmente como trabalhador pelo engajamento do corpo numa rotina, comum à de tantas pessoas. A primeira instância desta expectativa de inserção no mundo do trabalho não era a relação salarial ou o emprego em si, mas sim o seu potencial como estruturador na existência humana (Ribeiro, 2014), ou, como assinala Dejours (2004), quando afirma que "o trabalho é aquilo que implica, do ponto de vista humano, o fato de trabalhar" (p. 28).

As limitações decorrentes da deficiência também influenciaram a construção de perspectivas profissionais. Ao longo da juventude, como é comum às pessoas que planejam uma vida profissional, planos sobre a carreira foram sofrendo alterações para se adequarem a uma atividade de trabalho possível, como exemplificado abaixo:

Marcela: Antes eu gostava muito de animais. Eu, até o começo da minha adolescência, eu queria fazer veterinária. Daí eu ficava pensando: como que eu vou atender um cliente, baixinha desse jeito, se eu não consigo pegar um cachorro no colo. [...] gente, como é que eu 
vou enfiar a minha mão na vaca? Era muita coisa. Aí comecei a ter uns bloqueios em questão à veterinária e comecei a ter contato com Design Gráfico [...] quero trabalhar nesse mercado de comunicação. Mesmo sendo uma pessoa tímida, eu via que eu conseguia conversar mais assim, através de imagem, de texto.

As expectativas profissionais, nem sempre promissoras ou variadas, encontraram na realidade da busca por um trabalho, poucas oportunidades para se efetivarem. Aqueles que iniciaram suas experiências de trabalho no campo, em regiões mais pobres do país, a única oportunidade foi o trabalho na lavoura, comum à maior parte dos adultos.

Pedro: A minha vida lá no Nordeste foi essa: eu trabalhava na roça. Plantava milho, feijão, mandioca e limpava roça.

Ricardo: Então eu trabalhava capinando mato, mais todo esse pessoal grande.

Estas experiências ilustram que falar de "mercado de trabalho" como um único lugar, homogêneo, onde ofertas e demandas de emprego se confrontam e se ajustam em função dos salários, onde todos os trabalhadores podem se candidatar para qualquer vaga ofertada, exclui toda a complexidade desta análise, que segundo Oliveira e Piccinini (2011), exigem o olhar para as relações, mercantis e não mercantis, aí coexistentes. Como alertam os autores, nas abordagens do mercado de trabalho os aspectos sociais são desconsiderados. A dinamicidade das relações entre indivíduos, instituições e sociedade exigem considerar que ele não é estanque e nem se comporta como algo dado a partir da interferência em um dos eixos. Vários outros aspectos, como a diversidade de atividades profissionais, localização geográfica dos empregos e da mão de obra, graus de qualificação exigidos, se justapõem e diferenciam as estruturas de mercados, afetando diretamente as oportunidades de trabalho que cada um tem em cada lugar.

A Lei de Cotas, que obriga empresas com mais de cem funcionários a contratar pessoas com deficiência, é válida para algumas regiões, que tem empresas deste porte, sendo uma oportunidade para aqueles que veem nela uma chance de trabalho protegido. Em regiões de baixa concentração industrial e afastadas de grandes centros urbanos, as pessoas com deficiência jamais serão alcançadas por estas políticas afirmativas, restando a competição por trabalhos locais, em condições iguais de disputa a outras pessoas sem deficiência.

Para estes entrevistados, a imigração para São Paulo motivada pela busca de emprego não trouxe resultados imediatos. Conscientes da baixa escolaridade, a busca por empregos nunca obteve êxito. Nem mesmo nas funções onde há baixa exigência de qualificação ou experiência profissional eles conseguiram contratação. Como assinalam Oliveira e Piccinini (2011), nem todos os postos de trabalho estão igualmente disponíveis a todos os 
trabalhadores, porque para algumas pessoas são interpostas barreiras ao longo da vida, impedindo que todos se beneficiem do mesmo nível de educação e treinamento. Para Castel (1998), esses trabalhadores estariam numa zona de desfiliação, onde a precarização e a fragilidade social os deixariam à margem da sociedade salarial.

Pedro: [...] porque no mercado de trabalho eu tenho ali duas carteiras profissional. Eu apresento as duas prá você... tem contrato, mas registro de trabalhista, não, funcionário aí de alguma empresa. Quando eu cheguei, eu corri atrás de várias empresas e tal. E naquele tempo as portas eram fechadas pros deficientes. Corria atrás e tal e não teve jeito. [...] aí eu nunca ganhei dinheiro assim, registrado numa empresa. Eu nunca fui registrado [...] E eu tenho vários amigos que trabalham aí em umas empresas. Já trabalhei também, mas não fui registrado. Num posto de gasolina, frentista [...] Quando eu cheguei em São Paulo eu bati em várias empresas aqui, poxa. Eu queria arrumar de faxineiro e os caras não arrumavam. Pra barrer o chão lá, sei lá. A limpar, arrumar. Aí, quer dizer, vai chegando numa ocasião que você vai ficando chateado. [...] Eu acho que eles ignoravam o meu tamanho ali. Eu fiz várias fichas. Aqueles Amarelinho, eu comprava direto.

Ricardo: Eu mandei (currículo) prá várias empresas [...] Mas nunca eles me chamaram. Nunca. Não tive sorte nisso aí, com esse negócio (lei de Cotas) aí. [...] Não vou mais não. Porque muito tempo eu fiz isso. Acho que mais de doze anos eu fiz isso, e nunca consegui nada mesmo [...] Mas também, eu não tinha muito estudo, né?

Joaquim: [...] me deu aquele desespero, porque eu já tinha procurado em tudo quanto é de lugar. Às vezes, as empresas não me aceitava [...] As pessoas não queriam, não queriam, porque não queriam, porque falava que não, que não tinha condições, que não me via eu numa metalúrgica, numa fábrica, tudo.

Um dos entrevistados, a partir de usa experiência de buscar emprego, caracteriza a dimensão psicossocial do nanismo, que gera discriminação e reduz a identidade do outro a um estereótipo, fazendo a partir daí suposições a respeito de capacidades. Este é um exemplo claro de estigma, como apresentado por Goffman (2002). A partir dos atributos evidentes em sua conformação física, a sociedade estabelece meios para categorizar a pessoa com nanismo, utilizando como uma única imagem aquela geralmente disseminada pela mídia, que a associa ao palhaço, ao circo, ao bizarro, ao engraçado, como exemplo de uma "carreira moral" (Goffman, 2002, p. 41) disponível para estes estigmatizados.

Joaquim: [...] Aí eu procurava emprego, né? As empresas falavam assim: você tem que trabalhar em circo; você tem que trabalhar em circo porque, sabe, o quê que tem aqui pra você fazer? [...] Assim, porque eu tinha carteira branca, né? Assim que a gente fala, sem registro nenhum.

Para um dos entrevistados, as expectativas profissionais sempre estiveram atreladas a um projeto de trabalhar no mundo artístico. Os pais, que trabalham na área, o estimularam desde cedo a fazer as próprias escolhas, a ter autonomia. Tomando como referência a 
perspectiva epistemológica dialética sobre "projeto de vida de trabalho" citada por Ribeiro (2014), observa-se que o depoente articula estratégias para conjugar um trabalho que satisfaz suas possibilidades de existir no mundo, mas não é valorizado socialmente, com um trabalho que lhe permite uma relativa segurança financeira em razão do salário e de sua estruturação no tempo-espaço.

Leonardo: [...] mas eu sempre soube que queria ser ator, desde os quinze anos eu trabalho como ator. Bom, fui buscar um estudo no Ensino Superior em outra área por questões de preconceito da sociedade em viver com arte, tudo mais, das dificuldades e acabei optando pelo Turismo, mas sempre deixei o teatro em paralelo. [...] Meu pai é professor de Educação Artística. Ele trabalhava com cenário. Minha mãe é professora de Literatura. Então a escrita sempre teve presente. Livros de monte assim. Então eu tinha essa coisa dentro de mim.

Os entrevistados mais jovens relataram que a busca por trabalho não foi demorada, pois já puderam usufruir de mecanismos mais modernos de recrutamento, como as redes sociais, onde as empresas divulgam vagas para atrair candidatos, e de organizações nãogovernamentais que fornecem capacitação profissional e fazem a intermediação de mão de obra neste mercado movimentado pela Lei de Cotas. Apesar de encontrarem um mercado de trabalho mais aberto e de reunir qualificações desejáveis para a área de trabalho na qual se graduaram, a internalização do estigma se manifestou no momento de construção do currículo. Registrar ou não no currículo que tem nanismo? Se candidatar ou não como ator para um papel que não é estereotipado? Estas dúvidas se somaram à desconfiança a respeito da própria capacidade e ao medo da rejeição do empregador ao descobrir se tratar de um candidato com deficiência. Para Goffman (2012), um indivíduo estigmatizado pode se sentir inseguro em relação à maneira como os normais irão identificá-lo e recebe-lo.

Marcela: Procurei e achei até que fácil. [...] No currículo eu sempre coloquei que eu era portadora de nanismo. Era uma dúvida que eu sempre tinha. Colocava ou não colocava? O que é melhor? A pessoa já saber antes de me entrevistar que eu já tinha nanismo ou depois, e me ver assim? [...] Eu pensava assim: eu acho que não é nada demais. A pessoa só vai me ver, vai ver o meu currículo e vai ignorar aquilo. Então, aí eu coloquei. Aí eu fui chamada prá entrevista. A mulher conversou comigo normal. Em nenhum momento lá se tratou desse assunto. Ela só tratou desse assunto no seguinte. Ela falou: você precisaria de alguma coisa? Você precisaria de alguma adaptação? Aí ela perguntou se tinha lista de adaptação. Eu falei: não, meu trabalho é no computador, prá mim é tudo normal. [...] E eu tenho uma mania, que eu preciso tirar essa mania, de, por exemplo, eu acho que isso foi sorte, as duas entrevistas que eu fiz na vida, eu não fiz mais de duas entrevistas, eu passei! Então eu não sei se isso é pela minha qualidade ou se é a curiosidade [...] Eu penso mais, tipo, se a pessoa, digamos, se ela tem um preconceito muito grande comigo, ela vai saber resolver isso melhor olhando no meu currículo do que me vendo em frente a ela. Porque tem muita gente que não sabe esconder esse preconceito que segura dentro de si e acaba me afetando. Então, eu prefiro que a pessoa não me afete, já veja no meu currículo e me descarte. [...] E até prá não duvidar da minha capacidade, eu acho. Por exemplo, meu currículo já tá colocado ali que eu sou portadora de nanismo, mas já tá colocado todas as empresas que eu trabalhei, todas as minhas habilidades, 
as ferramentas... [...] Os cursos que eu já fiz. Tá tudo, tudo ali. Então a pessoa já vai ver e dizer: nossa. Tipo, isso não é... o problema do nanismo, então, não é nada. Tipo, descarta. Deixa só o que é importante.

Leonardo: Aí eu fiz o curso de capacitação [...] Era o único com nanismo do grupo e aí, depois do curso, que durou, acho que foram seis meses, [...] Aí fomos direcionados, cada um pra uma área [...] comecei a trabalhar na [...] Financeira [...] E, registrado como auxiliar administrativo, que é a porta de entrada (riso) e o que é oferecido pra início, né? De carreira [...] Já deixei de mandar o meu currículo, o meu material, as minhas fotos, os meus vídeos, de trabalhos meus, por não ser um perfil específico meu. Sabe: ah, eles não tão precisando de anão, eu não vou mandar material. É um filme, mas eu queria muito fazer, o tema me interessa muito, o personagem é muito interessante, mas eu não vou mandar meu material porque eu não vou ser aceito. Já rolou. Já rolou de eu mesmo me bloquear, mas hoje em dia eu faço o contrário. Eu falo: oh, sou ator, tenho nanismo, tô mandando o meu material, caso encaixe com algum perfil aí, eu tô disponível.

A inserção no mundo do trabalho exige uma separação, ainda que temporária, daquelas pessoas com quem se tem um vínculo afetivo mais intenso. A rotina de estar junto de parentes e de outras pessoas que oferecem a sensação de proteção e segurança é modificada quando se dá a inserção no mundo do trabalho. A autonomia para o deslocamento diário, a convivência com outros funcionários e clientes para quem se presta um serviço, a subordinação a regras e imposições de objetivos organizacionais e condições de trabalho, entre outros elementos, tornam necessários novos arranjos relacionais e emocionais, como narraram alguns entrevistados.

João: Meu primeiro trabalho, eu não esqueço até hoje [...] O cara falou: ó, você vai ter que ir lá e levar esses documentos. Eu gelei. Veio um gelo na minha barriga e eu falei: puta, lascou meu [...] Medo. Medo. Dependência. Porque minha dependência era ter minha irmã, [...] que sempre andava comigo, minha mãe e a insegurança de você ser um ser e andar sozinho. Entendeu? Você fala: meu, eu tenho essa responsabilidade na qual eu tenho que realizar e efetivar esse trabalho. Deu muito medo. [...] De estar sozinho entendeu. Até isso, até hoje eu tenho isso.

$\mathrm{Na}$ teoria do reconhecimento, Honneth (2003) associa o desenvolvimento da autoconfiança à primeira esfera do reconhecimento: o amor. Como primeira forma de reconhecimento intersubjetivo, nesta fase a relação de dependência estabelecida com os pais, sobretudo com a mãe, deve dirigir-se para o sentimento de autonomia. Segundo o autor, a ligação entre a experiência do reconhecimento e a relação consigo próprio resulta da estrutura intersubjetiva da identidade pessoal. Ao receberem o encorajamento dos outros, os indivíduos aprendem a se referir a si mesmos como dotados de qualidades e capacidades, desenvolvendo uma autorrelação positiva. No depoimento do entrevistado acima, pode-se notar uma insegurança inicial para a participação autônoma na vida pública, o que, segundo a teoria, 
estaria relacionado à frustração no reconhecimento por parte de seu pai, conforme ele mencionou ao retratar sua relação familiar.

Quando indagados sobre as dificuldades de inserção das pessoas com nanismo no mercado formal de trabalho, muitos entrevistados apontaram que os fatores que mais contribuem para essa situação são a baixa escolaridade e falta de qualificação profissional. Além disso, a facilidade com que encontram trabalhos em eventos, onde desempenham papéis estereotipados e são remunerados por isso, os deixa numa situação "cômoda", fazendo com que parem de buscar um trabalho formal. Como já discutido anteriormente, os itinerários da vida de cada trabalhador pertencem a uma inscrição de pertencimento em muitas esferas da vida, determinantes e norteadores de muitas direções que delimitam o possível e o impossível da realidade circunscrita. Para Guimarães (2010, p. 166), "falta aos indivíduos as precondições para se apresentarem na situação de procura como 'bons demandantes de trabalho"".

João: Eu acho que as pessoas com nanismo, [...] se acomodou muito em eventos, estão ganhando muito fácil. Tá dando pra viver. Mas quando a situação muda ... [...] Tem muitos anões que não terminaram o terceiro colegial. Tem muitos anões que se optam, aqui eu tô ganhando e aqui eu tô tendo. [...] tem muitos anões que, meu, não se preocuparam em estudar, em tá no colégio... [...] Mas não adianta você ter segundo colegial e chegar lá e sentar na mesa e não fazer porra nenhuma. Você entendeu? O banco manda você ir embora [...] Agora, por falta de trabalho... não! Tem muito. [...] Mas se você não tem o segundo colegial, você não tem opção de vida. [...] Escolaridade. Qualificação.

Leonardo: [...] Eu conheci algumas pessoas com nanismo que vê isso como uma facilidade. E não buscam se aperfeiçoar naquilo que fazem. É tipo: ah, eles precisam de um anão prá fazer peça. Beleza, vou lá fazer. Mas você quer ser ator? Você é ator? Você vai estudar? Você vai atrás disso? [...] Eu conheci pessoas que eram aposentadas pelo LOAS, recebiam o auxílio LOAS e levavam o artístico como uma fonte a mais de renda. Então, ela não queria ter um registro em carteira, não queria ter uma profissão com registro em carteira pra não perder o LOAS, o benefício, mas trabalhava nessa parte artística pra complementar essa renda. Então, veem como uma facilidade. Ah, eles me querem só porque eu sou anão, então eu vou lá, ser o palhacinho e tal, e não buscam o aperfeiçoamento. Hoje em dia, no Brasil, são poucas as pessoas com nanismo que buscaram estudar, que buscaram ser atores e atrizes mesmo, se aperfeiçoar [...] Elas se acomodam nesse lugar cômico de humor, que é o dinheiro fácil, e aí não buscam melhorar.

Entre as dificuldades de inserção no mercado de trabalho está o ostracismo a que se submetem muitas pessoas com nanismo. Evitar frequentar novos lugares, evitar grupos sociais, seria uma maneira de evitar as reações sociais negativas mediante a sua presença, o que, segundo a opinião de entrevistados, é um fator de abandono e desistência escolar e que tem impacto na ampliação da escolaridade.

Leonardo: Eu acho que faltou... teve um período muito grande de déficit, assim, de preconceito muito grande em que as pessoas se escondiam, ao invés de sair prá sociedade, o 
que fazia com que elas não buscavam estudos. E consequentemente não tem capacidade prá... não ter uma capacitação profissional prá entrar no mercado de trabalho. [...] Mas conheço muitas pessoas com nanismo que não terminaram o Ensino Médio, que não terminaram, às vezes, o Ensino Fundamental. E isso porque, talvez também, por uma visão preconceituosa. [...] A dificuldade de sair na rua e enxergar olhares, de pegar um ônibus, de pegar... Criar-se um bloqueio dessa pessoa de ir atrás ou estude. E eu acho que isso ficou, ficou... ficou um período das pessoas com nanismo, ficou com uma entressafra de pessoas não capacitadas prá conseguir entrar no mercado de trabalho. Eu acho que hoje, os mais jovens, das pessoas com nanismo, estão indo atrás de fazer faculdade, tão indo... Hoje, a gente tem uma aceitação melhor, e uma condição melhor de se expor pro mundo, e de atrás dos seus sonhos, de ir atrás dos seus estudos, de realmente eu quero ser arquiteto, eu quero ser médico, eu quero ser advogado, eu vou estudar. E acho que as condições são melhores, apesar de ter muito a melhorar, eu acho que são melhores do que há dez anos atrás. [...] E acho que as condições são melhores, apesar de ter muito a melhorar, eu acho que são melhores do que há dez anos atrás.

O ostracismo se relaciona ao medo que o indivíduo tem de que os outros possam defini-lo apenas com base no seu estigma, sentindo-se por isso desrespeitado. A simples previsão de contatos hostis pode leva-lo a esquematizar a vida de forma a evitá-los (Goffman, 2012), o que contribui com o isolamento social.

\subsubsection{Trabalho Desprotegido}

Os entrevistados com maior tempo de inserção no mercado de trabalho tiveram em sua trajetória experiências sucessivas de trabalhos desprotegidos, sem registro em carteira, sem estabilidade, dentro ou fora do espaço produtivo das empresas, em atividades temporárias, sem contrato regulado, recrutados temporariamente para a realização de trabalhos eventuais, em atividades que exigiam baixa qualificação. Como apontam Jordão e Stampa (2015), no processo de mercantilização do trabalho, a informalidade continua sendo a alternativa de muitas pessoas para o pertencimento ao mundo do trabalho.

Os que trabalharam como vendedores no comércio ambulante, eram subempregados de outros trabalhadores informais "mais estáveis" (Antunes, 2015), ocupando uma posição no mais extremo da instabilidade. Na prática, isso se traduzia em grande precariedade, com a inconstância dos rendimentos, sempre baixos, e em atividades de baixa posição no mercado de trabalho, como office-boy, vendedor ambulante, caixa, entre outras.

João: Office-boy, serviços de banco, depósito, pagamento de funcionário, pagamento de terceiras. Foram três meses de experiência, aí tentaram me efetivar e não conseguiram. [...] Porque era vaga prá tipo estagiário. Eu entrei no lugar de uma pessoa que tava de licença. [...] Trabalhei cinco anos de office-boy [...] Aí quando eu saí [...] eu fui trabalhar de caixa [...] Eu trabalhei dois anos lá. 
Pedro: Quando eu cheguei em São Paulo, ali no 98, 99, 2000, eu trabalhava na vinte e cinco de março, vendendo passe e cartão telefônico [...] o cara me humilhava sabe. O cara pagava três real por dia prá mim. [...] Eu ganhava três real e olha, ele pagava pra mim um hot dog, uma água, o dia. Trabalho escravo. [...] Aí chegou um ponto em que eu conheci um senhor cego, um cearense. Aí ele disse: quanto é que tu ganha aí por dia? [...] aí eu disse, Seu Francisco, eu ganho sete real por dia, ele me paga um almoço [...] ele disse, vem trabalhar pra mim; eu te pago vinte e cinco real por dia. [...]Era prá andar com ele, o cego. [...] Aí, daí, eu vi uma placa lá de office boy e tal e eu digo: eu vou lá Seu Francisco, não quero trabalhar com o senhor mais não. O senhor é um grande amigo, mas eu não quero, que eu acho que eu tô explorando o senhor [...] fui trabalhar de office boy.

Ricardo: eu tinha que entregar mil panfletos prá ele, o dia inteirinho, e ele me dava um real, só pra mim tomar um... comer duas coxinhas na época [...] Era vendendo cartão telefônico e passe de ônibus. Eu vendia bastante. [...] Aí o cara me disse: eu vou te dar cento e cinquenta reais. [...] Mas te dou um real só três horas da tarde, se você terminar de entregar o panfleto. Aí eu passava o dia inteirim com fome. Aí teve o Maranhão, que ele me ajudou bastante a comer, me ajudou bastante com a comida, inté que depois de um mês que eu trabalhei prá esse cara, aí o Maranhão foi e falou: poxa cara, você não quer vir trabalhar pra mim, não? Aí as coisa começou a melhorar o movimento. Ele disse: eu vou te dar quinze reais e o almoço, e a passagem prá você ir embora. [...] trabalhei muito de camelô. [...] Não podia mais trabalhar correndo na rua, que o rapa não deixava, né? [...] Quando o rapa vinha, eu apanhava o tabuleiro na cabeça, saía correndo, aí o pessoal saía gritando: oh o tripé invisível. Que via só o tabuleiro, mas não via o tripé que era eu.

Os relatos apontam uma vida de trabalho que combinava experiências de desemprego com períodos de trabalho extremamente precário, realizado em situação de rua, sem proteção, sem direitos trabalhistas, sem contrato, sem limites de jornada, expostos à humilhação tanto por parte de quem aluga sua força de trabalho como por parte do Estado, que ameaça quem trabalha sem licença com a apreensão das mercadorias. Sem ter outro meio para obter recursos para o sustento, estas pessoas estavam sujeitas a condições de trabalho que lhes impunha privações até mesmo de uma alimentação minimamente adequada. Como ressaltam Jordão e Stamba (2015), o trabalho precário está intrinsecamente relacionado à precarização da própria vida, pois repercute em todas as dimensões da vida social do indivíduo.

Entre aqueles que já tinham buscado, sem sucesso, um emprego, a experiência da precariedade também se evidencia no trabalho informal. Negado o direito ao trabalho no mercado formal, este entrevistado considera uma "benção", um "presente" quando uma pessoa da família o convidou para lecionar para os filhos. Esta primeira oportunidade marcou o início de sua vida de trabalho.

Ney: E aí, em 1989, com um não na cara, eu tive o presente, a bênção de uma colega, de uma moradora do outro lado da rua chamar a mulher que hoje é minha cunhada pra dar aula para os filhos dela, pra dar reforço [...] Das quatro da tarde às cinco e meia, às seis horas. Fiquei um ano, numa casa só. E a vizinhança começou a descobrir, a prestar atenção, e a mulher começou a me divulgar e eu comecei a dar aula no Paraisópolis. E aí não era só das quatro às cinco e meia na casa dela. Era das sete da manhã às dez e meia da noite, de casa em casa. E depois de anos eu construí a minha sala de aula e aí a renda acaba sendo mais interessante onde os 
alunos vêm prá sua sala de aula. Então eu alfabetizei bastante gente, dei aula de reforço de Português, de Matemática, de trabalho, de Inglês ... de 89 a 2000.

Com novas demandas por seus serviços vindas da vizinhança e depois de pessoas de todo o bairro onde morava, ele conseguiu reunir condições para montar sua própria sala de aula, em seu ambiente doméstico, o que representou uma melhoria das condições de oferta do próprio trabalho. As dificuldades restritivas de locomoção da acondroplasia, associadas à extensa jornada de trabalho realizada em diferentes lugares ao longo do mesmo dia, tornava este trabalho bastante desgastante. A narrativa orgulhosa de ter conseguido ocupar todo o seu dia com um trabalho valorizado socialmente esconde os fatores de sua precariedade, quando somando a todas as ausências de direitos de um trabalho formal, esta atividade lhe exigia uma dedicação de mais de quinze horas diariamente, ocupando a maior parte do seu dia e, consequente, da sua vida. O descanso, o lazer, o tempo livre, são comprometidos pelo tempo do trabalho, tal como ocorre a outros trabalhadores em posições precárias no processo produtivo, como apontam Antunes (2015) e Jordão e Stampa (2015).

Muitos entrevistados deixaram clara a insatisfação com esta forma de colocação no mercado de trabalho. O imperativo da sobrevivência, combinada à falta de atributos valorizados nas empresas, assinalou um destino da informalidade para eles, onde eles precisavam vender as capacidades que possuíam.

Pedro: Mas no meu ponto de vista é assim, eu, se eu tivesse a oportunidade de ter emprego garantido, para mim era ótimo. Mas é a mesma coisa. Eu bati em várias empresas, mas eu não arrumei. Infelizmente não me deram oportunidade. Aí, moral da história, eu ganhei a rua. Virei camelô. Depois eu virei uma espécie de evento, fui fazendo evento, um evento aqui e outro acolá e entrava mais dinheiro. Aí eu me acostumei também. Conquistei isso aqui (casa), com negócio de eventos.

As condições socioeconômicas e culturais de cada indivíduo são fundamentais para ampliar ou restringir suas escolhas ao longo da vida. $\mathrm{O}$ acesso à educação, a qualidade do ensino, a estrutura social e familiar da qual fez parte, as condições de saúde, entre muitos outros fatores, permitem ao indivíduo, com ou sem deficiência, chegar à vida adulta em condições mais ou menos favoráveis às demandas de qualificação exigidas pelas empresas. Apesar da Lei de Cotas ter impulsionado a inserção de pessoas com deficiência no mercado de trabalho brasileiro, ela não tem sido suficiente para reparar as desigualdades decorrentes das condições de vida anteriores à vida produtiva. A falta de correspondência entre os requisitos de especialização técnica e habilidades exigidas pelo empregador e aqueles apresentados pelos candidatos com deficiência é uma das justificativas alegadas para o não cumprimento da cota, como apontam Ribeiro e Carneiro (2009). Sem reunir estas 
qualificações, muitas pessoas com deficiência ficam à margem de um contrato de trabalho formal, submetendo-se a formas precárias de venda da sua força de trabalho.

Os entrevistados mais jovens, com Ensino Superior, que tiveram a oportunidade de adentrar o mundo do trabalho há pouco mais de três anos, quando as condições do mercado para o trabalho formal da pessoa com deficiência já eram mais favoráveis, tiveram experiências diferentes. Para eles, as condições de trabalho, a contratação para atividades compatíveis com suas qualificações, o ambiente seguro, o horário de trabalho definido, o desempenho em funções similares a outras pessoas sem deficiência da empresa, possibilitam uma via para autonomia. No tempo livre de LEONARDO, por exemplo, ele pode conciliar uma atividade de trabalho informal, onde se dedica a realizar um trabalho que lhe é significativo. Diferentemente de outros trabalhadores que combinam o trabalho regular com o ocasional pela necessidade de aumentar a renda, para ele era uma oportunidade de se dedicar ao trabalho que mais gosta, no mundo artístico. Para Marcela, apenas a primeira experiência de trabalho foi sem registro, em razão de um descumprimento do acordo feito na contratação.

Marcela: Aí eu achei uma gráfica perto de casa, que era especializada em convites de
casamento [...] Pertinho de casa. [...] Era muito legal. Eu trabalhava com convite de
casamento. Eu gostava muito. Você tinha contato com noiva. Você conversava... Era muito
interessante. [...] Quase dois meses. Foi um tempo muito curto. Aí eu fiquei até pensando
depois: ainda bem que não registrou, senão ia estragar a minha carteira. Então foi um emprego
que eu levei mais como experiência. [...] Uma loja de roupa masculina que vendia roupa pela
internet. E-commerce. [...] Eu fui contratada, como estagiária dessa vez. Ele assinou tudo
direitinho. Eu tinha seguro de vida e aí, a empresa teve que se mudar, prá uma região muito
longe. [...] Aí conversaram comigo prá eu oferecer pro meu chefe fazer home office. Aí o meu
chefe aceitou. Aí eu fiquei um pouco mais de um ano fazendo home office e ia, às vezes, prá
empresa, quando eu tinha carona. Sempre meu pai me levando. Leonardo: [...] Então eu trabalhava durante a semana em escritórios [...] final de semana eu fazia teatro [...] eu resolvi largar tudo e falar: não, vou viver do meu sonho mesmo, que é ser artista. Sou ator e poeta hoje em dia.

Os trabalhos em eventos, de pouca duração e esporádicos, são chamados de "bicos" devido às suas características: poucas horas de duração, pelas quais recebem o pagamento. Os trabalhos feitos para agências de publicidade, podem gerar ganhos um pouco maiores, mas são mais esporádicos e sazonais, restritos a períodos festivos em que personagens como o “anão da Branca de Neve", "duende de Papai Noel”, presentes nos contos e lendas infantis e que compõem o cenário criado em centros comerciais de grande circulação na época do Natal são encenadas. Trabalhos em programas de humor na televisão geram maior visibilidade pelo alcance de maior público, o que se traduz em maiores ganhos financeiros não só pela atividade em si, mas por alavancar a participação em outros eventos em que a pessoa é contratada em razão de sua "fama", de ser reconhecida como "celebridade". 
É neste tipo de trabalho em que mais se destaca a estereotipia, onde a imagem da pessoa com nanismo é veiculada. Todos os entrevistados já fizeram trabalhos estereotipados, sendo que alguns deles relataram poucas participações em eventos e outros se dedicaram a esta atividade por muitos anos, conciliando com um emprego, enquanto outros se dedicam a ela até hoje, sendo sua única fonte de renda.

\subsubsection{Influência dos estereótipos nas oportunidades de trabalho}

Sem exceção, todos os participantes desta pesquisa já trabalharam desempenhando papéis estereotipados, seja em eventos de entretenimento, teatro, televisão ou peças publicitárias. Nas narrativas, foi comum o fato de receberem, em algum momento da vida, a sugestão para o encaminhamento ao mundo artístico, através do teatro ou televisão. Mesmo os mais favorecidos socioeconomicamente, que tem emprego e Ensino Superior, do mais novo ao mais velho, já fizeram trabalhos que utilizavam uma personagem construída sobre a imagem estereotipada do "anão". Enquanto que para alguns era um trabalho de final de semana, um "bico", para outros era a única atividade geradora de renda. No momento da entrevista, apenas dois permaneciam exclusivamente com este trabalho (Pedro e Ricardo).

Estas oportunidades de trabalho estão relacionadas ao que Ciampa (2005) chama de "fetichismo da personagem". Se nas relações sociais do cotidiano o estereótipo associado ao nanismo pode lhe trazer dificuldades em acessar empregos tradicionais, no "mercado do entretenimento" o significado das características sociais que lhe são imputadas são manipuladas comercialmente como atributo de força de trabalho em shows de humor e entretenimento. Como aponta Goffman (2012), o indivíduo estigmatizado pode utilizar sua desvantagem, seu "desvio" da normalidade, as preconcepções e expectativas normativas construídas a seu respeito, em uma base para organizar a sua vida. Dependendo do contexto em que o estereótipo era manipulado em favor do cômico, do riso do público, alguns entrevistados demonstraram satisfação ao trabalharem como artistas, obtendo um reconhecimento social que reverte seu descrédito e atributo profundamente depreciativo de "anão", para uma avaliação positiva, de "artista", passando a receber demonstrações de afeto até de desconhecidos em razão de sua "fama". O sentimento de rejeição experimentado antes da fama pode dar lugar, em muitos momentos, ao sentimento de ser aceito, admirado e querido por um grande número de pessoas. 
O recrutamento para este tipo de atividade se dá mais frequentemente no espaço público, quando as pessoas com nanismo são abordadas por produtores de eventos que lhes fazem o convite para a atuação em festas e programas televisivos. Vários entrevistados destacaram que receberam muitas sugestões ao longo de suas vidas para que se dedicassem ao teatro e à televisão, como se este fosse um caminho "natural" para pessoas com nanismo, aquele no qual a anatomia se emoldura profissionalmente.

$\mathrm{Na}$ trajetória de trabalho dos entrevistados, aqueles que atuavam no comércio ambulante abandonaram esta atividade quando passaram a fazer eventos, a convite de outras pessoas com nanismo que já atuavam na área ou de quem era responsável pela produção deles.

João: Trabalhei uns quinze anos em televisão [...] mas foi com vinte e três anos, vinte e quatro anos, que eu estava no centro de São Paulo no qual um produtor de TV me encontrou e falou: cara, você quer fazer uma pegadinha? [...] Aí o [...] virava para mim e falava: cara, por que você não faz teatro?

Pedro: Aí depois eu conheci uns anão e entrei pra televisão [...] Eu conheci ali no centro. Eu conheci aquele anãozinho [...] aquele que é bem pequenininho... [...] Aí no que eu conheci ele, ele já me levou numa agência e tal e aí eu me cadastrei lá. Aí na época ele tava gravando o Pânico [...] Aí pediram um anão e o [...] indicou eu pra uma produtora.

É notório que é a imagem em si da pessoa com nanismo o atributo essencial para que ela seja convidada para trabalhos estereotipados. Sua identidade é dada de imediato, sendo reduzida a "um traço estático que define o ser" (Ciampa, 2005, p. 140). Com a identidade colada a uma personagem construída por elementos culturais ainda vigentes, a liberdade de circular pelos espaços públicos sofre interferências do julgamento moral feito com base na sua aparência, tornando qualquer pessoa com nanismo suscetível ao agenciamento para estes trabalhos.

Marcela: Tava indo tipo balada, tava saindo com uns amigos e de repente uma menina parou: ah, sou produtora de eventos de uma festa e eu tô procurando um anão; você não quer ser? Eu falei: não. E era prá chacota. Era prá chacota. Era prá chacota. Eu ainda tento entender de onde tem pessoa que se submete a ser tratada com falta de respeito. Então, é um mercado, a impressão que dá, é que tá diminuindo, mas ainda tem procura. Tá diminuindo porque a gente não vê tanto na televisão. Parece que tá diminuindo na televisão. [...] No grupo aparece bastante. [...] trabalhos de uma noite. Não é um trabalho contratado. É o famoso bico.

Segundo Kruse (2001), pessoas de estatura média frequentemente relacionam indivíduos com nanismo às construções sociais que elas fazem a respeito de "anões", associando-os a entidades não-humanas, retratando seus corpos como objetos a serem ridicularizados ou usados como fonte de entretenimento, o que influencia no cotidiano de suas interações. Como assinala Le Breton (2006), antes de qualquer coisa, a existência é corporal e 
é por meio dele que a relação com o mundo é construída. As possibilidades de uso deste corpo estão atreladas a um conjunto de sistemas simbólicos construídos culturalmente e nele emoldurados. De fato, as pessoas com nanismo precisam lidar com representações históricas a seu respeito, como se estivessem sempre carregando consigo o status cultural de pessoa especial, pertencentes a um mundo mágico. Em pesquisas de Adelson (2005b), Kennedy (2003), Shakespeare, Thompson e Wright (2007), os participantes afirmaram que quando são vistos em público, sentem que são julgados com base em antigas crenças culturais e estereótipos, sendo banidos pela sua diferença. Para eles, estereótipos como "anão do circo" se entrelaçaram social e culturalmente nessa avaliação dos outros a respeito de si.

Perante uma pessoa com o corpo marcado por atributos associados ao cômico, inferências passam a ser feitas a respeito dela, atribuindo-lhe uma identidade social (Goffman, 2012). Nestas atividades que recrutam pessoas com nanismo com base no estereótipo, elas são colocadas à parte dos seres humanos, como se possuíssem características ou representassem qualidades não humanas (Ellis, 2013). Esta forma de tratamento dispensada a uma pessoa com nanismo "em cena" muitas vezes se estende a situações sociais da vida comum, quando são abordadas nos espaços públicos e confundidas com a personagem que encarnam para o trabalho. É como se os papéis desempenhados fossem tratados como uma realidade absoluta da pessoa (Almeida, 2006). Como relatam Ablon (1984) e Kruse (2001, 2002), comentários, provocações, risos, hostilidade, são alguns dos comportamentos sociais direcionados a eles, desconsiderando sua humanidade.

Muitos dos entrevistados jamais consideraram como possibilidade o trabalho com entretenimento, mas o desemprego e as dificuldades financeiras foram os principais motivos apontados por eles para ingressarem nesta área, levando-os a negociarem sua identidade e a forma com a qual ela será exposta.

Pedro: Cada um se vende pelo preço que dá, pra fazer seu trabalho e tal, né? [...] Só que tem coisas na vida também que eu não vou fazer. [...] Mas se a necessidade obriga a pessoa a fazer, então faz. É um dinheiro limpo.

Joaquim: Porque naquela época a gente não tinha muita escolha. [...] A necessidade. Aí eu fui lá [...] Você tem vaga assim, pra trabalhar de evento [...] Ele falou assim: tudo bem, você faz a ficha aí. Aí, depois, ele sempre jogava, jogava: você não é aquele que veio aqui uma vez, que recusou? Eu falei: não, não é, não sou eu não, o senhor deve tá enganado. - É sim, igualzinho. Eu falei: não, mas você sabe que às vezes, a gente, baixinho, se parece um com o outro. - Mas é sim. Eu falei: não, não é cara. [...] Ele falou: eu tenho certeza cara que é. Eu não queria dar o braço a torcer.

Leonardo: [...] já fiz eventos de aniversário, já fiz eventos de casamento, distribuindo bebida numa fase que eu tava sem trabalho, tava precisando de dinheiro e o que era oferecido era isso. Mas hoje em dia eu não faria mais. 
A área de eventos e entretenimento é reconhecidamente favorável a pessoas com nanismo que desejam um trabalho rapidamente, mostrando que ainda é lucrativa esta forma de dramatizar a diferença.

João: [...] porque é ligado ao cômico. Ele precisa do anão prá tá ali e dar um tapa pra fazer alguém sorrir.

Marcela: É fácil. Se eu tô desempregada e falar: preciso trabalhar de qualquer jeito. Só se for por dinheiro, porque não dá muito dinheiro isso. Esse mercado vai ser o único que vai me abrir de qualquer jeito.

Leonardo: Eu acho que o meio artístico é um tipo de favorecimento pro nanismo. [...] Só o meio artístico que é um refúgio, né? É uma fuga dessas pessoas, tipo que muitas vezes não tem uma qualificação profissional, não tem uma qualificação de estudo, não tem uma qualificação profissional, e acaba indo pro básico, pro simples, que é: eles querem a minha imagem, então tá aqui a minha imagem.

A existência deste mercado de entretenimento reflete valores morais e éticos ainda vigentes em nossa sociedade que ainda parece tolerar o agenciamento e o consentimento de pessoas com nanismo para estes papéis. Para Ablon (1984), Adelson (2005b, 2005c), Gerber (1992, 1996), Howells e Chemers (2005) e Kennedy (2003), a imagem cultural estereotipada de pessoas com nanismo continua a ser perpetrada por atividades muitas vezes descritas como degradantes e desumanas, sendo um convite para a contratação de animação em bares e festas, em shows de luta livre (Canossa, 2018), competições que utilizam a pessoa como objeto do arremesso em jogos de boliche, entre outras, com grande presença de público. O fato é que muitas pessoas ainda aceitam fazer esse papel de "freak" na ausência de outras oportunidades (Howells \& Chemers, 2005) ou como oportunidade que gera melhores rendimentos do que outras atividades informais e com condições de trabalho mais precárias.

Antigos espetáculos que tentam retratar as pessoas com nanismo como um "povo especial" tem sido até reeditados em tempos recentes. Lafraniere (2010) relata que um empreendedor criou um "parque temático de anões" na China, cobrando dos turistas cerca de US\$ 9 no ingresso para assistir a dezenas de anões fazendo uma versão de "O Lago dos Cisnes". Este "empreendimento" tem atraído muitas críticas de pessoas e associações que acham que exibir anões, além de ser imoral, é um retrocesso, ao tempo em que colocar corpos anômalos em exposição são uma forma de aguçar a curiosidade mórbida das pessoas. De maneira semelhante ao que responderam alguns entrevistados desta pesquisa, os trabalhadores com nanismo de lá alegaram que é melhor ter este trabalho do que estar desempregado. 
Com base nas compreensões teóricas do olhar, Ellis (2018) aponta que há um mecanismo de desvalorização do corpo da pessoa com nanismo em cena. Assim como o corpo feminino, filmes, anúncios e fotografias são criados a partir de um olhar patriarcal e masculino, que delineia imagens que o sexualizam e objetificam, retratando-o de forma submissa e violenta. Como parte da criação de traços de feminilidade, as imagens são proliferadas para criar e manter os ideais patriarcais. De forma paralela, o corpo do "anão" é frequentemente usado como metáfora visual para criar um mundo de fantasia, estranheza e diferença para um espectador de estatura mediana. Na literatura e no cinema são comuns personagens "anões" sendo maltratados, ridicularizados, tendo seu corpo agredido, ao tempo em que também são retratados como animais de estimação. De maneira ambivalente, seu corpo "esquisito" é desejado como um fetiche para a excitação masculina heterossexual, ao tempo em que lhe é negada a humanidade.

Os trabalhos estereotipados mais comuns relatados foram aqueles realizados em eventos, onde fazem a recepção de convidados, animação de festas infantis ou de adultos. Entre aqueles que já fizeram estes trabalhos, seja como atividade principal ou esporadicamente, há bastante consciência a respeito do motivo que leva à sua contratação: a imagem estereotipada.

Ney: Põe um anão agora no Natal. Aparece um monte de comercial como... duende! Se não tem duende [...] Do personagem criado em você. O duende é o personagem criado em você. Você vai ter que fazer ele.

Pedro: Vai ter uma balada ali, tem um anão para animar a festa e tal. Vive dum evento ali, fazendo papel de palhaço mesmo, sabe? De palhaço, tirando sarro, ou alguém tirando sarro do anão. A maioria arruma esse tipo de profissão. Muita gente usa prá tirar o sarro da cara.

Marcela: [...] aí a gente foi, todo mundo vestido de terno, todo social, cabelo arrumado, e a gente, tipo assim, ninguém parava prá rir da gente. Eu aceitei por conta disso. A gente tava ali como uma pessoa que trabalha em evento comum. [...] A gente recepcionava as pessoas e levava até as mesas ou então via se o nome estava na lista. Mas era um serviço comum. [...] Era todo mundo pequeno? Era. Era prá diferenciar? A intenção dele era ser diferente? Era. Mas tipo, a gente não foi, em nenhum momento, desapontado ou tratado com falta de respeito.

Ricardo: [...] às vezes eles gostam de fazer brincadeira na faculdade, entregar presente prás pessoas, aí chama a gente também pra ir lá se vestir de duende ou homem aranha, qualquer coisa lá pra brincar com a galera. [...] A gente vestia roupa do tipo homem-aranha, sabe, power ranger, Huck [...] pessoas que vai fazer aniversário, aí eles contratava a gente... um duende.

Joaquim: [...] eu ia trabalhar vestido de boneco. Eu tinha que dar vida prá esse personagem [...] eles ligaram pra gente, falaram assim: vai ter um evento aqui, eu quero vocês fantasiados, tipo de duende [...] as pessoas só imaginavam a gente no circo, fazendo palhaçada [...] Natal, o duende era contratado só pra isso.

Leonardo: [...] anão tequileiro, distribuindo bebida na boca do pessoal, só porque é anão e é engraçado. Já fiz. 
Observa-se que, mesmo quando julgam ser tratados com respeito, realizando trabalhos comuns a pessoas de estatura mediana, há a consciência de todos de que o motivo para sua contratação é a sua diferença, é a sua apresentação como "novidade" para os convidados. As representações mais comuns relacionadas ao nanismo reproduzidas pela indústria do entretenimento são apontadas como uma das razões pelas quais as pessoas deste grupo populacional ainda têm suas interações sociais do cotidiano marcadas pelo assédio, olhares e provocações (Adelson, 2005b; Kennedy, 2003). Os papéis frequentemente atribuídos a elas são, em sua maioria, aqueles onde sua estatura ou diferença corporal são o único atributo requerido. Segundo Adelson (2005), isto inclui papeis até para seres não humanos, como duendes e elfos.

Dos sete entrevistados, quatro trabalharam durante alguns anos em programas infantis e, principalmente, de humor veiculados pela televisão. Nos diferentes programas, com grande alcance entre a população, eles integravam o elenco como coadjuvantes, ficando bastante conhecidos pelo público. Os nomes dos programas não serão citados aqui, como uma medida de proteção da identidade dos participantes.

João: Eu fiz quinze anos direto programas.

Esta "fama" lhes garantia novos trabalhos em outros lugares, com os quais eles podiam conciliar e, assim, somar rendimentos para ganhos mensais maiores, visto que os cachês pagos, mesmo na televisão, eram de baixo valor. Financeiramente, este conjunto de trabalhos lhes possibilitavam uma condição de vida material melhor que um trabalho assalariado, com um salário baixo, ideia que, para alguns deles, representa uma "ilusão", pois contribui para manter pessoas com nanismo fora do mercado formal de trabalho, numa situação de bastante insegurança e vulnerabilidade.

João: Ganhava cento e cinquenta reais, cem reais, um cachezinho baixo, por dia. Você gravava duas ou três participações, era cento e cinquenta conto [...] Não dá pra viver de gato pingado. Não dá.

Pedro: [...] eu entrei nesse mercado e dava um dinheiro. Eu fazia uns shows, uns eventos [...] e eu ganhava um dinheiro. Puxa, tinha mês aí que eu tirava cinco, seis mil. E um salário, dependendo do salário da pessoa, é mil e quinhentos, dois mil, ou três, né? [...] eu ia ali e ganhava mil, ia acolá e ganhava mais quinhentos, ia ali e ganhava seiscentos, sabe?... aí, quer dizer, eu fiquei iludido nesse mundo aí. [...] A televisão é prá mim, um meio de ilusão. Eles usam você e depois ó, lhe joga.

Ricardo: Eles pensam que quem trabalha na TV tá rico cara. Tá rico é os apresentador, mas nós somo os figurantes tudo ali, ganha uma mixaria. Ganha uma mixaria. Ganha um salário que dá só prá gente viver mesmo. Pagar as continha, né? 
Leonardo: Comecei a fazer publicidade, fiz um comercial grande, entrou um dinheiro legal, eu me empolguei [...] Não ganha bem esses programas de humor. [...] Evento é uma coisa interessante. Assim, às vezes, o evento, você ganha pouco, mas é um curto período de trabalho, e, às vezes, você pega três ou quatro eventos no fim de semana. Então compensa, vamos dizer. Mas se você pegar isoladamente, não compensa nem um pouco.

Sem contrato de trabalho que o regule, algumas dessas atividades exigiam uma performance que colocava em risco a vida da pessoa com nanismo. Um deles narrou a participação em rodeios, evento organizado em moldes similares aos da Espanha (El Bombero Torero), México (Los Enanitos Toreros) e outros países, em que "anões toureiros" promovem o entretenimento do público ao desafiar bois "ferozes". Depois que o animal o pisoteou, colocando em risco sua vida, ele decidiu parar com a atividade, relembrando com tristeza o tipo de atividade ao qual se submetia para divertir o público, como descrito abaixo:

Pedro: Foi o mundo do rodeio. Fazer palhaço de rodeio. [...] eu ia morrendo no rodeio. O boi pisou esse pé meu aqui ó. Algum boi de mil quilos pisou isso aqui meu [...] Mas só que eu fazia palhaçada. Aí tinha uma palhaçada lá que eu entrava dentro de um tambor [...] Aí eu ficava ali dentro do tambor e daqui a pouco o cara soltava o boi, e o boi dava uma cabeçada. E eu lá dentro. Aí quando eu saía de dentro do tambor eu tinha que disparar prá correr, pra entrar na grade e sair fora, senão o boi me pegava. [...] E o pessoal tudo dando risada. A desgraça de um, os outros dá risada.

Ao questionar o que ele fazia para preparar seu desempenho no evento, ele diz: "Tomava um uísque". Este tipo de preparação para melhorar a "performance" artística, deixando a pessoa "mais à vontade" para se exibir ao público, também foi apontada por outro participante.

Joaquim: E, às vezes, as pessoas que a gente fazia eventos, queria que a gente bebesse um pouquinho pra gente ficar animado [...] Aí me empolguei, tudo, aí me prejudicou. Aí com isso, com o tempo, eu fiquei doente.

Para Margalit (1996), ao tratar o outro como se não fosse humano, rebaixando-o a uma categoria de objeto, animal, máquina, sub-humano, sua humanidade é levada a um estado de vulnerabilidade. Ao explorar esta vulnerabilidade do indivíduo, expondo-o à estigmatização no espaço público, são comprometidas condições básicas de respeito à dignidade do outro. $\mathrm{O}$ autorrespeito, que segundo Honneth (2003) se constitui na relação intersubjetiva de reconhecimento do outro, é ferido.

Assim como ocorre em outros grupos sociais, não basta ter um traço ou, neste caso, um "desvio" que se enquadra na imagem a ser construída no mercado publicitário, de eventos ou trabalhos artísticos na televisão ou teatro. Ser pequeno, talvez, seja apenas o atributo principal para a construção de uma personagem, como um duende de Papai Noel, por 
exemplo. Assim como outros trabalhos que envolvem a imagem, a cor da pele e a aparência foram apontados como relevantes. Dois dos entrevistados, homens, brancos, demonstraram estar conscientes a respeito de características que os tornam, em muitas situações, preferidos em relação a outras pessoas com nanismo.

João: Sempre que eu fui num comercial fazer teste eles estimavam muito pela aparência da pessoa, entendeu? $\mathrm{Eu}$, graças a Deus, sempre tive a aparência que se adaptava ao vídeo que eles queriam. Por isso que eu fiz tantos comerciais entendeu [...] Teve um ano que eu fiquei entre os três shoppings, um dos maiores de São Paulo.

Leonardo: Já ouvi muitos comentários, quando eu tava na novela, na TV, de muitas pessoas do meio, que já trabalham há anos, falando: meu, cê tem tudo pra dar certo na TV, porque você tem olho claro, você é... tem o cabelo claro, você é branco. É, porque eles adoram a fotografia de novela adora olhos claros. [...] somos ainda uma sociedade muito machista, muito, é... padrão europeia, né? O eurocentrismo prevalece, ou o que é bonito na TV. Vamos colocar alguém de olho claro, vamos colocar alguém loiro. Pode ver, todas as atrizes, atores. Eu acho que eu levo vantagem nesse sentido sim. [...] Eu levo sim vantagem e assim como outros atores brancos, de olho claro, loiros, levam vantagem sobre mim.

Pelos relatos é possível assinalar que nem todas as pessoas com nanismo experimentam barreiras ocupacionais no mesmo grau ou são afetados de igual forma na valorização do seu atributo diferencial. As experiências de viver com nanismo, apesar de mediadas pela deficiência, também são atravessadas por gênero, cor da pele, aparência, idade, entre outros fatores que interferem na valoração que este corpo, tomado como mercadoria, irá receber. Segundo Shakespeare (1996), classe, idade, sexualidade, gênero e grupos étnicos afetam a experiência social e econômica de deficiência. A indissociabilidade entre o subjetivo e o social, entre o contexto e a pessoa, produz experiências diferentes no cotidiano, expondo cada um a formas de vivenciar os efeitos da deficiência de maneira diversa.

Ainda que a maior parte dos trabalhos publicitários, em eventos, em programas de televisão, sejam estereotipados, outros trabalhos que dependem do desempenho artístico e não apenas da imagem da pessoa com nanismo, reduzidas ao estereótipo, também foram citados.

Ney: Aí eu fui fazer comerciais de carro, de chiclete, a fazer minisséries na televisão, participar de programas na televisão [...] No programa da televisão, um professor. Na minissérie da cultura, um bêbado que frequentava um forró e via um assassinato e namorava uma fofinha. Que mais? Fiz comerciais temáticos, claro. Teve sete anões para o comercial do carro, mas fiz um roqueiro, um comercial do chiclete. Foge um pouco sim do estereótipo.

Leonardo: Eu comecei fazendo ano passado [...] é aquela coisa do speakeasy, dos bares proibidos na época da Lei Seca nos Estados Unidos. E aí eles colocaram um anão prá recepcionar, no caso, e a porta tem uma abertura gigante. Então, você tem que subir uma escadinha, a pessoa fica com medo, tem que falar uma senha, você abre a porta. Mas eu aceitei porque tem toda uma encenação ali, tem um trabalho artístico muito grande. Não é somente o fato de eu ser anão. [...] é um chamariz diferente, é uma questão física, visual, mas é um trabalho artístico. 
As características físicas da pessoa com nanismo também são alvos de fetiche por parte de algumas pessoas, repercutindo em seus desejos sexuais ou vistos como amuletos de sorte. Estes resultados vão ao encontro dos estudos realizados por Kennedy (2003), em que os participantes também relataram que suas imagens eram utilizadas de forma pornográfica e seus corpos vistos como fontes de objetificação sexual.

João: diretores da [...] filmes pornográficos, e que ofereceu a maior grana prá nós. Trinta pau pra cada um. Eu falei: meu, me atiçou, porque eu tava duro? Pra caramba! [...] meu, eu nunca, na minha vida, tinha entrando num swing [...] Eu entrei pra conhecer. E aí veio um cara com muleta e falou: cara, o cara te dá seiscentos reais prá você transar, transar com a mulher dele. A mulher dele tem tara por anão.

Joaquim: [...] me chamaram há muito tempo atrás para fazer stripped, nessas casas aí do Centro [...] Porque chama a atenção, gera a curiosidade, tanto das mulheres, dos homens [...] que a gente tem algo diferente na gente. [...] Tinha lá, nós fizemos um buffet, uma festa, um evento. Era uma casa de chá [...] Tudo idosas [...] Só tinha só aquelas madames [...] nós fomos convidados [...] Pra servir chá lá prás madames. [...] Aí, a senhora, de repente, a uma certa altura, agarrada na nossa bunda sabe. [...] É porque disse que dá sorte segurar [...] eles imaginam de tudo.

Leonardo: De olhar o anão como um fetiche, como o diferente, de trazer algo diferente prá apimentar a relação [...] Rola essa questão do tamanho do pênis do anão, aquelas coisas todas que vem carregadas de preconceito, mas que as pessoas acham que é um elogio. [...] Você enxergar somente como um objeto sexual.

Grande parte destes trabalhos estereotipados são alvos de polêmica entre os que tem nanismo, pois algumas reclamam o direito de não terem sua identidade associada à comicidade e se sentem prejudicadas quando são representadas de forma estereotipada em programas de humor ou em eventos. Para elas, esses trabalhos reforçam o processo de estigmatização por parte da sociedade, que estende a todo o grupo social as características de uma personagem. A dissociação entre a personagem artística, a pessoa fora da cena, todo o grupo social, é comprometida, sendo mais um desafio a ser vencido nas interações sociais.

Marcela: A pessoa, tipo, foi abordada na rua por conta de um personagem de chacota na televisão, sendo que não tinha nada a ver. Ela só tava seguindo a sua vida ali e por conta de uma graça, que todo mundo ri, ele foi abordado, tipo, ele teve sua rotina interrompida [...] Você sai na rua e você é algo [...] Isso nunca foi uma coisa que eu aceitei. Até hoje eu não aceito. [...] Além de televisão, tem o circo. Ainda existem circos que trabalham com isso. [...] eu não sei dizer, se eles fazem porque gostam ou se fazem porque há falta de oportunidade [...] é a mesma coisa que a televisão, né? Reforça o preconceito. [...] Porque é estereotipado. A pessoa que faz graça é a pessoa com nanismo, é o anão. [...] Se você colocar uma pessoa pra fazer graça, que tem nanismo e uma pessoa sem, o público de fora, por tá acostumado com aquilo, vai rir da pessoa que tem nanismo. Então, eu acho que é um estereótipo que tá muito fixado na sociedade e as pessoas ainda ficam lá provocando. Sendo que não precisa mais. Tem tanto emprego por aí. Tem tanta oportunidade.

Leonardo: Eu acho que sim, porque essa coisa de enxergar a pessoa com nanismo como cômico ou como a figura bizarra, estereotipada, padronizada, enfim, perde a credibilidade 
daquela pessoa comum, que tá querendo um emprego comum, que não é das mídias, que não é do meio artístico, que não quer explorar a sua imagem, que quer somente que acredite na sua capacidade... Eu acho que cria uma barreira prá essas pessoas de... da sociedade levar a sério a pessoa sabe. Sempre leva no humor, sempre leva na comédia. Você vai ser consultado por um médico com nanismo, você vai procurar outro, porque: ah, ele é anão; não deve nem saber o que tá falando. Eu não sei. Eu ainda acho que a imagem do anão é estritamente cômica. A sociedade ainda enxerga como cômica, como o engraçado, e é muito difícil assim, darem credibilidade prá capacidade ou para o que a pessoa com nanismo tá falando, por conta dessa imagem criada ao longo do tempo.

Assim como nos resultados obtidos por Ellis (2018), alguns entrevistados consideram que a popularidade de personagens encarnados por pessoas com nanismo em programas de entretenimento tem influenciado o público a estender o tratamento humilhante que ocorre no trabalho de exibição cênica a todas as outras pessoas de igual condição física, na vida real. Para Honneth (2003), ao expor publicamente uma pessoa como insignificante, não se fere apenas a autoestima da pessoa, mas também a do grupo ao qual ele se sente pertencente, ferindo sua identidade e prejudicando os relacionamentos intersubjetivos.

Neuhäuser (2010) trata da humilhação do grupo representativo, em que todo um grupo é humilhado a partir da humilhação de um ou mais de seus membros, sendo afetado, de alguma forma, por sanções da sociedade. Individualmente, pessoas com nanismo são humilhadas porque pertencem a este grupo social, ao tempo que este nível de humilhação direcionado a alguém, na vida social ou encarnando uma personagem para trabalhos artísticos, constitui uma humilhação simbólica do grupo. Atitudes sociais reativas, como exemplificado pelo processo movido por uma pessoa com nanismo contra um programa humorístico, demonstram como o autorrespeito pode ser afetado, mesmo que a pessoa não seja vítima direta da humilhação.

Apesar de apontarem que estes trabalhos estereotipados promovem o reforço e a reprodução do estigma, a posição de muitos entrevistados a respeito desta realidade leva em consideração tanto a desigualdade de condições na disputa por outras formas de trabalho quanto à opção individual de se encaminhar ou permanecer nesta área do entretenimento e comicidade.

João: [...] Eu não tenho nada contra com quem trabalha ou deixa de trabalhar. Você até poderia colocar isso prá mim me respondendo o seguinte: o país hoje te dá condições de trabalho. Muitas. Emprego tem sobrando. [...] Ator é ilusão.

Ney: [...] eu aprendi que eu sou privilegiado. Eu posso fazer arte, eu tenho conhecimento de mundo, tenho repertório, gosto de estudar, tenho uma segunda língua que é inglês, tenho faculdade de Letras, tenho o ensino superior, tô indo pra uma Pós, tô indo pra um mestrado e doutorado [...] Mas tem gente que não tem. Tem gente que só tem aquela diária de cem reais prá fazer o ridículo na televisão. E eu não sou a melhor pessoa prá criticar. Eu acho uma pena 
alguns grupos de outros pequenos ficar emputecido porque tá denegrindo a minha imagem. Mas ele só tem aquilo. [...] Mas tem gente que só tem aquilo.

Marcela: Mas pelo que eu vejo de vagas e pessoas, mesmo sem formação entrando em banco, porque o banco dá essa oportunidade, oferece cursos prá pessoa ingressar e tudo o mais. Eu acho que essa parte da comédia é uma opção. Não sei por qual motivo, mas é uma opção. [...] Os pequenos procuram. Tem pequenos que procuram só isso. [...] eu acho que as pessoas que se submetem a isso é por conta da escolaridade mesmo [...] Eu acredito que ela viu a única oportunidade dela ali, independente de como ela fosse tratada. Como até, então, ingressar no mercado de trabalho sem uma graduação é difícil, ainda mais pra gente, ela tem que se submeter a isso. Igual, por exemplo, tem uma pessoa no grupo, acho que já é um senhor, tem anos de experiências, só que ele não tem graduação. Ele tem experiência de trabalho. Não consegue arranjar emprego. Eu não conheço ele, prá dizer se é por falta de oportunidade ou se na área dele tá complicado, mas já ofereceram prá ele essa área, de entretenimento, que ele conseguiria porque não precisa de nada, só precisa ser baixinho. [...] Mas você não precisa trabalhar com algo que gere preconceito na rua ou que gera preconceito contra você mesmo. [...] Lógico que muitos casos dessas pessoas que tão na televisão são essas pessoas que tiveram falta de oportunidade.

Leonardo: Eu não sei se é uma facilidade ou uma dificuldade. Prá mim, eu que sou ator, que eu quero ser ator, que eu estudo, que eu quero ser reconhecido pelo meu trabalho artístico e não pela minha condição física, pra mim é uma dificuldade, porque os personagens são sempre os mesmos. Agora, prá pessoa que tá acostumada a fazer o evento, a receber as pessoas numa festa, a distribuir tequila porque é anão, porque é engraçado, é uma facilidade de fonte de renda. Então eu acho que tem os dois lados. Prá quem quer ser artista, pra mim é uma dificuldade. Pra quem quer só uma fonte de renda no campo artístico, é uma facilidade [...] Então, eu vejo um grande problema nas pessoas que aceitam isso. Eu vejo um grande problema porque aí o mercado artístico começa a... fica enxergando a gente só nessa condição. E aí gera um problema prá nós, artistas, atores profissionais, que querem algo maior, e a sociedade vai continuar enxergando a gente da forma cômica. Então, é um reforço daquilo que já acontece na humanidade há séculos. De enxergar o anão como uma figura cômica. Então, quem aceita isso, tá reforçando essa visão estereotipada, essa visão cômica, essa visão do ridículo [...] Do bizarro, [...] Mas, eu também conheci pessoas, que tem o outro lado também, que é a única fonte de renda. Então, elas precisam disso prá sobreviver. Então, eu procuro, eu procuro não julgar, mas acabo julgando, as pessoas que aceitam esse tipo de trabalho, mas isso compromete a carreira nossa também, de quem quer fazer algo diferente, de quem quer construir uma imagem melhor, assim, da pessoa com nanismo. [...] A ascensão em todos os tipos de carreira, porque você vai chegar numa sala prá ser atendido por um médico anão, você vai rir. Você não vai enxergar ele como um doutor, como um profissional. Você vai contratar um advogado anão, a hora que você abrir a porta prá receber ele, você vai falar: mas pera aí, eu contratei um advogado. Então vai continuar tendo essa visão limitada do nanismo pro cômico. Porque você tá vendo na mídia, você tá vendo na TV, o tempo inteiro isso acontecendo em programas de humor. Você tá vendo no cinema, você tá vendo em filmes.

Segundo Goffman (2012), o indivíduo pode manter ou não um vínculo com sua categoria social estigmatizada. Alguns podem afastar-se de seus pares ao vê-los se comportando de modo estereotipado, exibindo-se de forma a reforçar atributos negativos que lhes são imputados, mesmo que permaneça uma identificação social e psicológica com eles e um sentimento de repulsa e vergonha se desenvolvam. Outros podem recusar o lugar social que lhes foi destinado pela sociedade a partir do estereótipo, repudiando trabalhos que 
reforcem e ajudem a perpetuar a reprodução de uma identidade social estereotipada. Estas reações criam desentendimentos nos grupos de pessoas com nanismo, pois se situam entre a liberdade individual de fazer um trabalho estereotipado, seja por vontade, pela remuneração atrativa ou por ser a única oportunidade obtida em momentos de dificuldade financeira, e o direito de toda uma categoria social de não querer ter sua imagem continuamente associada ao estereótipo e ser afetado por ele no seu cotidiano.

Na opinião de Shakespeare (2003), um pesquisador que tem nanismo, este grupo populacional parece ser um dos poucos grupos minoritários em que ainda é considerado aceitável ridicularizar na TV. Para ele, ser considerado um "modelo de comédia", significa que pessoas de estatura mediana irão rir de todas as outras pessoas com nanismo. A fonte desta comicidade, segundo Bergson (2007), é justamente a imaginação das pessoas de estatura mediana, que transfiguram a pessoa com nanismo em coisa que, mesmo que objetificada, conserva características humanas.

A mídia cumpre papel importante neste processo de reprodução da estereotipia do “anão". Com um grande alcance de público, ela é responsável por construir uma imagem da identidade da pessoa com nanismo ligada a um papel, uma personagem, geralmente em contextos de comicidade. Para este público, a única representação a respeito da pessoa com nanismo é formada ali. Como consequência, a única recordação de ter visto uma pessoa com nanismo, num certo contexto, comportando-se de determinada forma, é imediatamente acessado ao se deparar com uma pessoa no mundo real. Para os entrevistados, assistir a programas em que eram representados de forma pejorativa sempre lhes causou muito incômodo.

João: Só que, infelizmente, no país que a gente vive, você não vê artista, um anão artista. Você não vê! Você não vê! Você só vê anão apanhando em [programa humorístico]. Você ser figurante de programa.

Marcela: Sempre que, por exemplo, em casa, caía num canal desse, eu saía da sala, não gostava de ver, e acho até hoje não gosto. Fico pensando: prá quê que uma pessoa vai se submeter a ser alvo de preconceito? A gente sempre quer fugir disso. E a pessoa reforça aquilo. Não precisa. A empresa não precisa de audiência por preconceito. Você tá dando essa oportunidade a ela. Se você não der essa oportunidade a ela, ela vai encontrar outros meios. Não precisa afetar diretamente a gente [...] Porque é algo que todo mundo vê. É algo que, tipo, todo mundo desde criança vê na televisão. Acha engraçado. Sempre tem visto o anão desse jeito. Como tem poucos anões no Brasil, muitos acabam não conhecendo outros na rua, não acabam tendo a oportunidade de trocar experiência, de ver que a gente é uma pessoa normal, que trabalha normal, que estuda, que tem fillho, constrói uma família. Eu acho que por não ter outro tipo de informação fácil, de fácil acesso, as pessoas, sem que elas tenham que procurar sobre nós, acho que acaba, ainda, sendo estereótipo que todo mundo leva.

Leonardo: Eu consigo ver, mas me incomoda, sim. Às vezes, eu chego a mudar de canal. A hora que eu vejo, eu falo: ah, não, não quero ver isso de novo, não quero ver mais do mesmo. 
Mas eu busco ver até porque eu conheço essas pessoas, então eu busco ver o quê que eles tão fazendo, se tão mudando a postura. Eu acho que alguns vem mudando a postura, que trabalhavam com comédia e vem tentando estudar, tentando virar artista, realmente ator. Mas me incomoda, sim. Me incomoda. Me incomoda mais pelo que o público tá assistindo, tipo, eu fico pensando o quê que as pessoas que tão assistindo vão pensar daquilo e como isso vai refletir no meu dia a dia na rua, do que o que ele tá fazendo ali. Tipo, o que ele tá fazendo ali é problema dele, a vida é dele, mas o reflexo daquele... A gente tem essa coisa de assimilar a imagem que tem na TV prá nós, né? Então você vê uma pessoa com nanismo, você traz pra você. Você fala: putz, é dessa forma que vão me enxergar. E isso incomoda.

Para quem escolheu a profissão de artista, tem sido difícil desvincular papéis desempenhados em novelas, teatros, eventos e campanhas publicitárias do estereótipo, pois os narradores concebem os papéis disponíveis para ela com base no seu físico e concentrando a representação da personagem apenas em seu atributo diferencial. Como ressalta Hughes (1999), a pessoa prejudicada torna-se sinônimo da sua "condição" física, que o torna significativo e conhecido apenas por ela.

Leonardo: Eu lembro que alguns testes eu cheguei a mandar material sem dizer que eu era anão. E eu fui chamado pro teste e a pessoa se surpreendeu quando eu tava lá. E aí eu fiz o teste e foi criado um personagem prá mim que não existia. Então eu sempre tive essa... Ah, não é meu perfil, mas eu vou mandar meu material. Vamo ver se eles topam. Vamo ver se eles aceitam. [...] Eu vou mostrar que eu sou mais do que um anão. Vou mostrar que eu sou um ator, que eu consigo fazer qualquer tipo de personagem. E assim eu fui indo. Fui me inscrevendo em... Fui mandando material prá personagens que não tinham nanismo. Outros tantos convites eram prá personagens que eram pra ser anões ou que eram uma figura cômica. [...] Eu fui aceitando alguns tipos de trabalhos que hoje em dia eu não aceito mais porque eu já construí uma carreira de respeito que vai na contramão dessa questão do estereótipo da pessoa com nanismo no meio artístico, e eu consegui construir esse caminho na contramão, mas foram... foi e tá sendo ainda, um caminho muito longo e de batalha, porque as pessoas estão acostumadas com essa visão, historicamente, da Idade Média, de ver o bobo da corte sendo um anão, sendo um corcunda, [...] Falava: meu, isso me incomoda um pouco; a gente pode alterar, a gente pode fazer de uma outra forma, a gente pode fazer de uma forma mais sutil ou de uma forma que não ofenda aos outros anões e tal? E foi, foi dando esse espaço. Foi bacana, assim, essa construção coletiva que eles deram oportunidade de eu fazer. E é isso que eu venho buscando também com os meus trabalhos, tentando, mesmo que seja um personagem estereotipado, tentando fazer um caminho inverso ou contornar essas situações prá que fique menos agressivo ou menos ofensivo pra nós, né?

Exatamente por causar este tipo de prejuízo à imagem a uma categoria social é que, por vias judiciais, outras pessoas com nanismo tentaram reprimir este tipo de atuação na televisão. Para dois entrevistados, atores em programas de humor, cujo papel preconizava o rebaixamento moral das personagens por eles interpretados, o impedimento deste trabalho por medida legal trouxe muitos prejuízos para a sua carreira artística e, consequentemente, financeira. 
Ricardo: Aí, vão, ajuntaram uma Lei prá acabar com aquilo ali, pra querer tirar aquela pessoa que tá dentro, vamos supor, dentro da TV pra cavar um termo pra eles poder sair fora dali. Isso eu acho errado. Por isso que eu falo: o mundo é prá todos. Se tem umas pessoas que têm sorte, vamos torcer prá eles, né? Não vamos querer tirar a sorte que Deus deu pra eles.

Marcela: Outro dia eu saí da (emissora de TV) por causa de um processo duma anã [...] Ela processou [...] Aí me afastaram [...] E na época eu tava ganhando três mil, fora os eventos que eu fazia sabe. Eu tirava seis, sete mil por mês. Aí foi onde eu ajuntei e comprei esse lugar aqui prá mim [...] Eu tenho uma filha pra criar, chega conta de água, luz, telefone, sabe, e a minha alimentação que eu preciso... não é vocês que vão pagar [...] Ela ganhou porque foi tipo uma difamação [...] Estava prejudicando a imagem dela que ela falou. Mas não era a imagem dela, era a minha. Por ela ser anã, ela ficou ofendida.

A dignidade humana é o principal fundamento filosófico dos direitos humanos, conforme expressado na Declaração Universal dos Direitos Humanos. Nesta Carta, o reconhecimento da dignidade inerente a todos os membros da família humana e dos seus direitos iguais e inalienáveis são considerados o fundamento da liberdade, justiça e paz no mundo. Por essa razão, Neuhäuser (2010) chama atenção para aqueles casos de humilhação em que o indivíduo, além de não ser visto como um membro plenamente aceitado da humanidade, também não possui autocontrole necessário para o respeito próprio, o que, em si, é humilhante. Portanto, não se trata apenas de uma noção psicológica de humilhação, mas uma noção normativa dela, que justifica que as humilhações não precisam ser sentidas para existirem, como aponta Margalit (1996). Com isso, não só a dignidade de um indivíduo pode ser violada, mas quando outras pessoas que se sentem pertencentes ao grupo populacional ali representado na humilhação, é a dignidade de um coletivo que pode ser violada.

Para alguns participantes, estes trabalhos estereotipados parecem estar diminuindo, até mesmo na televisão. O fim de programas infantis e de humor, a substituição temática de personagens fazendo duendes no Natal por objetos de decoração, são alguns dos fatores que contribuem para essa diminuição.

Joaquim: Porque sabe, programa de televisão é assim, né? Muito rápido. [...] você não vê mais em shopping com duende. Só o Papai Noe 1[...] Eu acho que ficou muito cansativa essa imagem [...] São mais enfeites de tecnologia avançado [...] É a mesma coisa de programa infantil. Qual é o programa que tem hoje, infantil? Nenhum. [...] A criançada hoje de sete, oito anos, ela não quer mais ver o palhaço. [...] Ela quer o celular, ela quer isso, quer aquilo, quer um $[\ldots]$. 


\subsubsection{Lei de Cotas}

Com a vigência da Lei de Cotas, a mobilidade ocupacional se tornou possível para aqueles que já haviam concluído o ensino básico e possuíam qualificação profissional. Quem não reunia essas condições, permaneceu fora do mercado de trabalho formal, fazendo eventos direcionados ao entretenimento. Alguns entrevistados, já contratados por empresas em vagas reservadas para pessoas com deficiência, continuaram a conciliar o trabalho formal com o trabalho no mundo artístico fora do expediente do emprego.

João: Aí já entrou na Cotas. Eu comecei a trabalhar [...] como atendente e como realizar matrícula dos universitários. [...] Eu fui trabalhar na secretaria... [...] E aí, eu conciliando faculdade, [nome da empresa], eu fazia eventos à noite. Eu fazia eventos em bazar à noite e correio elegante.

Ney: Só que antes de eu ir prá faculdade de Letras, eu tô atravessando a rua e uma senhora: olha, aquele colégio ali, é um dos colégios particulares do bairro do Morumbi, está precisando de gente igual você. E eu: Oi? Como assim, igual a mim? Me desculpa, como é que fala? Eu falei: não sei, você que me parou na rua. Ah... era a cota! Eu acho que a mulher trabalhava nesse colégio. Eu fui bater na porta do colégio. Escuta, me disseram que a senhora está precisando de gente igual a mim. Eu repeti, eu reproduzi a fala que eu ouvi na rua. Eu fiquei quatro anos e meio nesse colégio particular, trabalhando meio período.

Joaquim: [...] Aí depois veio a Lei de Cotas, né? Aí começou a melhorar, a respirar [...] é que nem eu tô falando, essa cota, se acabar, acaba com a gente. Infelizmente é isso. Eles tão ali pra, tipo assim, uma obrigação, preencher cota.

Para os entrevistados, especialmente os de maior idade, que já acumularam longa experiência em trabalhos desprotegidos anteriormente, a Lei de Cotas foi um marco para a mobilidade ocupacional. Do trabalho informal, em eventos e ligados ao entretenimento e comicidade, à possibilidade de um trabalho regulado juridicamente, com direitos trabalhistas e proteção social, exercendo funções comuns. Como afirma Guimarães (2009), a mobilidade ocupacional é como uma avenida para a mobilidade social, para uma posição de prestígio e uma melhoria nas condições financeiras.

João: Eu quero ter uma aposentadoria porque: uma, não pagam INSS; dois, não tem um contrato, um registro; terceiro, não tem um seguro de saúde; vai colocando num papel... Quando eu ficava doente eu ficava em fila de posto de saúde, entendeu? Não tinha o meu carro, andava de ônibus, com dificuldades, discriminação e problemas, entendeu? ... Então é assim. [...] O [...] ele me propôs, ele me deu de presente a minha cirurgia, que era caríssima. Nunca ia ter condições financeiras de fazer.

Ney: [...] lá atrás, o não que eu recebi na cara, era porque não tinha cota, não tinha a filha da puta da obrigatoriedade que é a única coisa que move esse povo e esse país. [...] A cota é prá empresa não pagar multa. Mas eu não tô lá por assistencialismo, não. Eu trabalho. E trabalho como gente grande. [...] Eu estaria dando aula em Paraisópolis e só. Porque aí eu não sei se eu teria acordado pra Jesus e ter ido fazer a faculdade de Letras. [...] Mudou. Tem um facilitador. 
Sou grato a isso. As pessoas têm que usar mais. Tem gente que não sabe o direito que tem. Não conhece!

Marcela: Mas eu acho que emprego, oportunidade de emprego, hoje tá muito melhor do que antes. Quando eu converso com os meus amigos, eles falavam que antes dessa Lei era muito difícil. Ainda mais que a gente era visto como chacota, era muito difícil.

Para os que são mais jovens, que tiveram uma trajetória educacional regular, diferente dos demais, não há uma percepção clara da mudança nas oportunidades de trabalho provocadas pela Lei de Cotas. O Ensino Superior e o nível de qualificação alcançado podem encontrar limitações nas oportunidades ocupacionais postas ao alcance dos candidatos com deficiência, o que motiva uma busca de emprego fora da cota, concorrendo a um processo amplo de seleção.

Marcela: Nunca vi na minha área. Às vezes eu acho que as vagas pra pessoas com deficiência
são prá trabalhos muito comuns e a maioria são pra área financeira. Assistente de RH,
Assistente Administrativo sabe. Essas vagas que, por eu não procurar, eu vejo. Então eu
acredito que não tem tanto na minha área assim. Então eu penso que a acessibilidade no
trabalho nunca me afetou, a quantidade de serviço que me passavam nunca me afetou, então
eu penso: por que não continuar na vaga normal? [...] Eu sou como qualquer funcionário ali,
então, por que não? Assim, quando eu sentir dificuldade, aí eu procuro a vaga especial. Igual
também, muitos pequenos trabalham em banco, porque o banco oferece muita oportunidade
prá pessoa com deficiência, principalmente em caixa. [...] Mas eu acho que emprego,
oportunidade de emprego, hoje tá muito melhor do que antes. Quando eu converso com os
meus amigos, eles falavam que antes dessa Lei era muito difícil.

Leonardo: E, registrado como auxiliar administrativo, que é a porta de entrada (riso) e o que é oferecido prá início, né? De carreira. [...] Foi por cotas. Foi: vamos cumprir, precisamos pegar um cara de dezoito anos que tá saindo do colégio, que não tem conhecimento nenhum, e tem nanismo? Prá mim é por cotas. É: precisamos cumprir aqui, senão a gente vai tomar multa [...] Acho que, talvez, os primeiros empregos que eu consegui, acho que não teria conseguido se não fosse a Lei de Cotas. Os demais, talvez, depois da universidade, tal, acho que foi por capacidade intelectual. Mas também entrei por cotas. Não foi uma contratação comum, né? Não foi uma contratação...

Nos achados de Toldrá, De Marque e Brunello (2010) foi possível constatar que grande parte das contratações de pessoas com deficiência no mercado de trabalho partem de uma provocação das empresas às instituições de intermediação de mão de obra. Segundo as autoras, a maior parte das contratações ocorriam pela obrigatoriedade em responder às exigências legais de cumprimento da Lei de Cotas e, em menor número, por as empresas acreditarem nas capacidades profissionais do empregado. Assim como foi identificado por Lima (2012), nesta pesquisa também foi apontado que são as empresas que definem o perfil desejado de trabalhadores, geralmente com "pequenas deficiências", cabendo à instituição o recrutamento, capacitação e encaminhamento de pessoas que correspondem às demandas empresariais. Acompanhando as tendências do mercado de trabalho mais amplo, Oliveira e 
Piccinini (2011) ressaltam que estas redes interferem na organização mercantil, contrariando a ideia de igual disponibilidade de postos a todos os interessados.

$\mathrm{Se}$ as pessoas que foram recrutadas para programas de capacitação desenhados segundo a demanda do contratante são submetidas ao crivo das exigências logo no início do processo como uma forma de justificar a exclusão, aquelas que jamais puderam acessar estas oportunidades por sequer saberem da existência delas estarão sempre à margem desta inclusão. Como afirmam Oliveira e Piccinini (2011), o segmento do mercado de trabalho caracterizado por baixos salários, alta rotatividade de trabalhadores, falta de qualificação, possibilidades restritas de promoção e ausência de segurança no emprego é formado de trabalhadores em situação de fraqueza junto aos empregadores.

\subsubsection{Humilhação e Preconceito no Trabalho}

Muitos trabalhos estereotipados, principalmente aqueles ligados a programas televisivos de humor, exigem um desempenho que submete o trabalhador a um processo de subjugação, no qual a sua honra, respeito e dignidade são afetados, configurando-se uma humilhação. No trabalho como ambulante, os entrevistados também narraram sentimentos de humilhação em razão das condições precárias a que eram submetidos no cotidiano da atividade e da contrapartida em remuneração recebida pelo esforço dispendido. Nestes casos, a origem da humilhação não estava atrelada ao estereótipo, visto que poderia se estender a qualquer outra pessoa que trabalhasse sob as mesmas condições.

Ao falarem sobre a trajetória de trabalho em programas humorísticos e eventos, os entrevistados enfatizaram as experiências de humilhação, sobretudo na narrativa daqueles com maior idade, que acumularam mais experiências em trabalhos com eventos até sua inserção no mercado formal de trabalho por meio da Lei de Cotas.

João: [...] só que as brincadeiras eram inevitáveis, eram brincadeiras muito violentas. Batia, te empurrava, te tratava como objeto. Eu falei, porra, eu não estudei para isso meu. Mas eu preciso! E como minha irmã sempre diz [...] quem depende sofre. [...] Eu preciso desse dinheiro, eu preciso dessa oportunidade [...] Eu vou dar minha cara para o cara dar tapa, dar choque, zoar [...] [pegadinhas, eu fiz mais de cem pegadinhas prá ele. E eu falava assim: porra meu, não quero fazer pegadinha com status de combinado. Então vai lá e apanha! Ele cansou de falar isso prá mim. Eu quero apanhar meu. Mas eu quero fazer uma coisa que chama os olhos do público. Depois de umas três ou quatro deck de gravação, você pode pôr como combinado. [...] Eu me submetia muito, muito, a tomar porrada, apanhar, a ser rebaixado. [...] Eu não quero mais isso [...] Eu não vou entrar num programa de TV [...] pra ser judiado. Eu não quero ser judiado. 
Ney: Sabe aquele quadro que tem uma mão do King Kong que empurra? Então, cheguei prá produção: essa mão vai encostar em mim? Vai, só um pouco. Eu falei: Não, não vai [...] você impõe que as pessoas te respeitem. Agora se é um lesado qualquer, que não tem conhecimento, que não tem discurso, que não tem pulso firme, a mão empurra, ele cai, vai lá pro bueiro, estatela, se quebra todo.

Pedro: Aí eu entrei lá só prá eles tirar o sarro da minha cara. Que geralmente os anão nasceram pra ser saco de pancada. [...] Que a gente não merecia ser tratado assim também sabe. [...] No rodeio mesmo eu era humilhado meu. [...] Aí um cara me chamou de bicho feio: que anão feio do capiroto.

Ricardo: Uma vez ele me deu um tapa e quase me derrubou no chão. O tapa dele, a mão num cara bem pequenininho que tampou tudo aqui ó. Ave-maria, que tapa medonho [...] levar os tapa na cara né. Porque era verdade o negócio ali. Era ferroada ali né. E pense num tapinha que doía.

Joaquim: A gente vai fazer evento e o cara começa a beber, tacar tapa na cabeça, tudo, isso, aquilo outro, colocar apelido sabe, pejorativo [...] Tem programas assim, humorísticos, tudo, Os Trapalhões, eles saindo de lá, na rua, todo mundo trata eles com respeito [...] Ah, eu não gostava muito quando era aquela coisa de torta na cara, de brincadeirinha [...] De me vestir de boneco, eu nunca gostei muito. Eu gostava muito quando eu ia de cara limpa, que eu ia assim, como a gente fala né? De cara limpa [...] porque eu me sentia um pouco desvalorizado [...] As pessoas zoavam com a gente, dava tapa sabe, tudo, chutava, às vezes, sabe. Se com acondroplasia assim, normal, os caras já faziam, imagina um boneco. [...] eu vou brincar junto com a pessoa, eu tô ali participando, eu tô aceitando, eu tô brincando. [...] Há uma grande diferença, de que depois, opa, encerrei, vou prá casa, acabou. Incorporei, faz de conta que aquilo lá é meu personagem. [...] É um personagem que você tá fazendo. Apesar que torta na cara também é um personagem, mas assim, mas é que antigamente a televisão só dava valor prá gente pra isso daí, pra levar tortada e essas coisas mais. No sentido assim, pejorativo.

Para compreender a humilhação é preciso considerar a relação intersubjetiva aí estabelecida, entre pessoas com poder desigual. O humilhador, na posição de contratante do evento ou diretor da cena, encontra uma pessoa impotente, que encontrou uma oportunidade de obtenção de renda na comercialização e manipulação da sua identidade, desde que se submeta às condições daquele trabalho. Esse é um tipo de desrespeito que "toca a camada da integridade corporal de uma pessoa" (Honneth, 2003, p. 214). Na esfera de reconhecimento mais primária, do amor, o desrespeito se manifesta pelo rebaixamento pessoal que provoca um grau de humilhação ligado com o sentimento de estar sujeito à vontade de uma outra pessoa. $\mathrm{O}$ autorrespeito que cada pessoa possui, adquirido por meio do processo intersubjetivo de socialização pela dedicação afetiva, é diretamente violentado.

Como narrado acima, as cenas programadas para fazer o público rir em programas televisivos de humor exigiam uma encenação em que a violação ao corpo do outro, em forma de agressão, precisa se aproximar o quanto possível da realidade, deixando a pessoa com nanismo sujeita à vontade de outro. Para eles, não era suficiente utilizar-se de artifícios para 
parecer real. O que era exigido destas pessoas em cena é que se dispusessem a tornar fiel a realidade dos atos de violência.

Nos eventos, parece difícil a delimitação que deve fazer o público entre o trabalho da personagem que desempenha um papel temporariamente a fim de diverti-lo, e a própria pessoa, "desencarnada aquele papel”. Em todos os casos, o respeito pela disposição autônoma sobre o próprio corpo é subtraído, emergindo o sentimento de impotência e sujeição à vontade de outra pessoa que infringem a autorrelação de confiança, em si e no mundo, aprendida na esfera do reconhecimento do amor. Para Honneth (2003), essa forma de desrespeito se estende para as esferas de relacionamento prático com outros sujeitos, como uma vergonha social. $\mathrm{Na}$ percepção sobre o próprio valor, pode-se observar aí uma ofensa à honra social, o que Margalit (1996) denomina como insulto.

Apesar de estereotipados, não eram todos trabalhos em eventos que submetiam as pessoas a atos humilhantes. Os entrevistados lembraram que trabalhando como recepcionistas, em correio elegante e até em programas de auditório na TV voltados para públicos de todas as idades, não eram submetidos a insultos e agressões verbais ou físicas.

João: Recepção de festa, fiz muito. Eventos de festa de criança, fiz muito. Programas de tv, muito! Mas só que não era tão agressivo que nem o [programa de TV] [...] fazia outros eventos [...] e nunca me deram um tapa. Nunca me deram um tapa! Nunca me maltrataram!

Joaquim: Não de qualquer tipo de evento, mas tipo assim, que nem na casa noturna de correio elegante, meu, eu ia lá na sexta-feira, principalmente em final de ano, aí tinha o tal de happy hour, que é uns cliente novo, tudo, todo dia você tá conhecendo pessoa, tudo. A pessoa vai lá prá divertir, não tá brava, não tá nada. Porque eu gosto assim, de momentos alegres, de pessoas alegres [...] É super gostoso, descontraído [...] Então, prá falar a verdade, ainda gosto hoje, dependendo da participação em TV, assim, pelo menos o que eu já fiz, eu gosto mais de fazer evento do que de televisão.

As narrativas que ofereceram maior ênfase à humilhação estiveram relacionadas a programas humorísticos veiculados pela TV. O roteiro, construído sem a colaboração dos atores, continha cenas que colocavam a pessoa com nanismo em situação vexatória e em posição de desrespeito, como alvo de ofensas e insultos, objetivando tornar essa situação engraçada aos olhos do público. Numa cena realizada por um dos entrevistados, denominada por ele como "polêmica" em razão do processo judicial impetrado por uma pessoa com nanismo à emissora e ao programa no qual ele era hospedado, ele relembra:

Pedro: Eu fiz uma cena que o [...] dizia: entre na mala [...] Eu fiquei em pé, entrei na mala e a mala não me cabia. [...] Aí o [...] humilhou eu ali. Ele falou bem assim: entre aí seu anão, seu infeliz, seu condenado; você tem que ir prá ilha [...] pra Michael Jackson te enrabar. Aí, quer dizer, ficou aquele negócio meio chato sabe, meio humilhante. E quem é anão não aceita, meu, 
ser humilhado [...] era um programa meio pesado prá mim[...] eles querem fazer sem falar. Surpresa. Sempre surpresa prá mim.

Esta situação guarda semelhanças com outros trabalhos que usam a estereotipia ligada ao nanismo como forma de entretenimento. Em países como Austrália, Canadá, Estados Unidos e França, a prática de "arremesso de anão" também gerou diversas polêmicas na sociedade, até serem terminantemente proibidas, mesmo sob o protesto de pessoas com nanismo que eram submetidas à prática. Neste "esporte", surgido na Austrália na década de 1980 e espalhando-se pelo mundo, desde então, elas vestiam trajes protetores para serem arremessadas em colchões por pessoas de estatura mediana que competiam entre si por um lançamento mais distante. Na França, esta prática foi proibida na cidade francesa de Morsangsur-Orge em 1992, passando pelas cortes administrativas de apelação quando Manuel Wackenheim reclamou o direito de ser "arremessado", alegando que a decisão era discriminatória e violava o seu direito ao trabalho, fonte de sua sobrevivência. O caso saiu da esfera jurídica local e foi levado a à Comissão das Nações Unidas para os Direitos Humanos ${ }^{9}$, que em 2002, manteve a proibição por considerar necessário manter o respeito da dignidade humana.

Tomando como comparativo este caso acima, Chiesse (2014) faz uma análise sobre os quadros humorísticos do programa brasileiro "Pânico na TV", exibido entre os anos de 2003 e 2017. Com números expressivos de audiência e de empresas patrocinadoras, este programa traz como expressão de humor conteúdos e cenas que colocam seus integrantes em situações humilhantes, como objetos de diversão alheia, piada, fazendo deles objetos da brincadeira. Para ele, assim como no caso de arremesso de anões com o Sr. Manuel Wackenheim, o trabalho desenvolvido no Pânico violava o princípio da dignidade dos seus integrantes.

Numa possível defesa das práticas deste programa, poderia ser alegado que seus integrantes teriam permitido as brincadeiras. Como no caso francês, atores poderiam reclamar sobre o prejuízo com o fim deste tipo de trabalho, como forma de violação de um direito ao trabalho. No entanto, Schreiber (2011) afirma que no ordenamento jurídico brasileiro, “a autolimitação ao exercício dos direitos da personalidade deve ser admitida pela ordem jurídica

\footnotetext{
8 Arremesso de Anão. In Wikipedia, a enciclopédia livre. Recuperado de https://pt.wikipedia.org/wiki/Arremesso_de_an\%C3\%A3o

Lançamento de Anão. Recuperado de https://www.youtube.com/watch?v=GKkLfudrK1Y

Arremesso de anões. Recuperado de https://www.youtube.com/watch?v=Ta9AbGXr_GM\&t=52s

9 "Manuel Wackenheim v France, Communication No 854/1999, U.N. Doc. CCPR/C/75/D/854/1999 (2002)". Recuperado de http://www.equalrightstrust.org/ertdocumentbank/Microsoft\%20Word\%20\%20Manuel\%20Wackenheim\%20v.\%20Fr.pdf;
} 
quando atenda genuinamente ao propósito da realização da personalidade de seu titular" (p. 27). Caso contrário, deve ser repelida todas as vezes em que não for guiada pelos próprios interesses de realização da dignidade e sempre que tenha caráter irrestrito e permanente.

Ao lado da duração e alcance da autolimitação, cumpre analisar a sua intensidade, ou seja, o grau de restrição que impõe ao exercício dos direitos da personalidade. Em exemplo pueril, o expectador de uma comédia teatral pode consentir em ser alvo de brincadeiras que façam o público rir. Sua autorização não permite, contudo que seja humilhado ou reduzido a mero objeto de lazer alheio... (Schreiber, 2011, p. 26-27).

Na cena narrada pelo entrevistado acima, ele mesmo reconhece que já havia alertado à equipe do programa: "essas cenas tão ficando pesadas", denotando o caráter repetitivo delas. Como ele observou, o roteiro cênico é escrito e dirigido de modo que os atores saibam apenas no momento o que fazer, o que dizer. A prescrição de humilhações, ofensas e até castigos físicos instrumentalizados como fator surpresa, a ser revelado apenas no momento da cena, propicia a vulnerabilidade do ator aos projetos alheios, visto que não havia consentimento prévio e nem momentos para reflexão sobre o roteiro, já que este não era objeto de conhecimento prévio.

Pedro: Uma cena drástica que aconteceu comigo. Que eu fiz um papel de merda. Imagina. O [...] fazendo cocô e eu era a merda lá embaixo no vaso, na montagem que eles fizeram lá, né? Aí quando essa cena rolou também foi a maior polêmica prá mim. [...] Aí, pô, você me colocando prá fazer papel de merda. Mas eu vou ser sincero. Até hoje em dia eu dou risada porque o [...] chegou em mim e falou: [...] você é um anão filho da puta cara. E eu disse: por quê? Porque só teve um cara... ele falou o nome do cara lá que fez papel de merda, e eu. Aí eu disse: ah, cara, eu... E eu, sem maldade, assim, inocente também sabe. Inocente. [...] Você é mandado pela aquelas pessoas e tal, e eu fiz.

O desejo de resistir e não se submeter à uma encenação vexatória para si não era atendido na maioria das vezes. Para se manter naquele trabalho, era preciso fazer concessões dos próprios valores em favor da fabricação do humor.

Pedro: Mas teve uma cena lá que eu xinguei até o diretor [...] Porque eles queriam que eu comesse sabe o quê? Que eu comesse minhoca. Aquelas minhoconas feias sabe. Eu dizia: eu como, mas tem um preço. Não, você vai ter que comer... Aí o G. pegou uma minhoca lá e passou na minha boca meu. Aí eu xinguei e tal, falei que ia desistir do programa [...] E eu dei um valor lá. Eu como por X. você me paga aí uns quinhentos mil reais que eu como aqui. [...] Não, tá caro... Não, não como não. Porque tem coisas, tudo vai do dinheiro sabe. Infelizmente, o dinheiro é maldito. O dinheiro é o que faz o homem, ou seja, o poder. [...] Esse papel eu rejeitei. Aliás, eu não rejeitei. Eu critiquei, eu briguei, e acabei fazendo na pressão, porque já era o final, entendeu? Aconteceu isso de eu não aceitar, mas foi pro ar, sem aceitar, entendeu. [...] Eles pega pesado. Se era prá comer barata... queria que eu comesse barata também eu disse: não. Ah, é de laboratório. Eu disse não, coma você, sua mãe, seu pai. Porque é onde vem assim, um lado que os anões num ponto tão certo, porque você não deve fazer tudo, é lógico, porque puxa, eu vou ganhar um dinheiro prá comer barata, meu. 
Ricardo: A cena que teve que eu não queria gravar era de jeito nenhum, quando eles me chamavam de "anão da bunda grande" [...] Aí eu saí de cena e eu falei que não ia gravar mais. [...] Aí eu fiquei com raiva. [...] Porque ele dizia que eu era viado. Eu não gostava. [...] Aí foi preciso o [...] vir falar comigo prá poder a gente gravar.

Como observado, a vida humana por trás do espetáculo é manipulada de forma que, para explorar a diferença, há também exploração do indivíduo, a quem é oferecido dinheiro para que aceite assumir o papel de aberração. Na Constituição Federal (Brasil, 1988), em seu artigo primeiro, situa-se entre os fundamentos do Estado Democrático de Direito a dignidade da pessoa humana ${ }^{10}$, sendo, portanto, uma qualidade intrínseca da pessoa humana, irrenunciável e inalienável (Awad, 2006). Qualquer tipo de restrição a ela é considerado sinônimo de violação. Para Sarlet (2002), não se pode tolerar aí relativização alguma, havendo a necessidade de respeitar, proteger e promover a igual dignidade de todas as pessoas. Difundido este princípio de dignidade da pessoa humana, é vedado que qualquer ser humano seja considerado como objeto, que sua condição de pessoa seja degradada.

Sobre o direito fundamental à liberdade negocial de se dispor ou não a fazer este tipo de trabalho, sob estas condições, Popp (2008) assinala que ele está diretamente relacionado à dignidade, pois sempre que o homem cai em extrema necessidade, a liberdade humana se debilita. Deste modo, "quanto maior a proteção à dignidade, maior será a liberdade real” (p. $60)$.

Pedro: Aí tem gente que ignora as cenas que eu faço, porque eu faço umas cenas nojentas e pesadas tem hora, sabe? Mas tem hora que eu penso, poxa, minhas contas chegam [...] não é você quem vai pagar.

No caso destas pessoas com nanismo, o histórico de trabalhos extremamente precários e de baixa remuneração os coloca numa situação de vulnerabilidade perante uma condição onde podem ser melhor remunerados, desde que aceitem suprimir condições de respeito. Ainda que seja estipulado um preço para dispor ao outro esta condição, assinala Barroso (2012):

Do valor intrínseco do ser humano decorre um postulado antitutilitarista e outro antiautoritário. O primeiro se manifesta no imperativo categórico kantiano do homem como um fim em si mesmo, e não como meio para a realização de metas coletivas ou de projetos

\footnotetext{
${ }^{10}$ Sobre a dignidade da pessoa humana, Awad (2006, p. 115): "Esclarece-se que há diferença entre as expressões "dignidade da pessoa humana" e "dignidade humana": aquela dirige-se ao homem concreto e individual, ao passo que esta dirige-se à humanidade, entendida como qualidade comum a todos os homens. A dignidade constitui atributo da pessoa humana individualmente considerada, e não de um ser ideal ou abstrato, não sendo lícito confundir as noções de dignidade da pessoa humana e dignidade humana (da humanidade).”
} 
pessoais de outros; o segundo, na ideia de que é o Estado que existe para o indivíduo, e não o contrário. É por ter o valor intrínseco de cada pessoa como conteúdo essencial que a dignidade humana é, emr primeiro lugar, um valor objetivo que não depende de qualquer evento ou experiência e que, portanto, não pode ser concedido ou perdido, mesmo diante do comportamento mais reprovável. Ela independe até mesmo da própria razão, estando presente em bebês recém-nascidos e em pessoas senis ou com qualquer grau de deficiência mental. (Barroso, 2012, p.32-33).

Em trabalhos realizados em conjunto com outros artistas sem nanismo, os entrevistados relataram que a distribuição dos ganhos financeiros provenientes da receita da bilheteria do evento era desigual, ficando uma pequena parte para eles. Isso não havia sido acordado previamente, o que os deixou surpresos ao descobrirem. Neste caso, observa-se que uma forma de desrespeito infligida às suas pretensões de reconhecimento jurídico por não ser considerada como profissional de igual valor nesta coletividade, já que não participa em pé de igualdade dos acordos comerciais firmados para os shows, mesmo que todo o show seja organizado em torno de seu estereótipo. Como assinala Honneth (2003, p. 217), “[...] a capacidade de se referir a si mesmo como parceiro em pé de igualdade na interação como todos os próximos" é afetada.

Pedro: Aí nos começamos a fazer show em teatro e circo. Aí tinha bilheteria que dava cento e vinte mil real e tinha que ser rachada pro circo e prá nós. Só que prá mim ele dava duzentos e cinquenta, pro E. ele dava duzento. Cachê de eventos entendeu. Mas só que era todo dia. [...] Aí entrava um dinheiro por fora. A gente ganhava mais dinheiro com show do que na TV você entendeu. [...] Eu até saí, porque quando eu descobri que estava dando duzentos mil de bilheteria e ele tava dando duzentos e cinquenta pra mim, e eu era o cara do momento... [...] eu chamei os cara tudo de ladrão. Chamei mesmo. Eu digo: vocês são um bando de ladrão safado; vocês estão usando a minha imagem meu; eu fazendo o show bonitinho, direitinho, fazendo o meu trabalho e vocês me dando duzentos conto, duzentos e cinquenta; não; cada um vai fazer seu show agora só. [...] Porque os meninos que criaram o show, eles estavam usando nós [...] Nós ganhamos cem mil e tu pega duzentos real e me dá e olha na minha cara: você é o cara e tal, sabe? Porque ficou com cem mil. Eles compraram apartamento na praia. [...] Eu acho que você pode usar o ser humano, mas vamo respeitar, entendeu?

Ricardo: E só era as pessoa que era mais esperta do que nós. Porque quando eles fechava show, eles sempre queria ganhar mais, né? Que a gente. [...] Acho que é porque eles era grande e prá nós era sempre o mais pouco. [...] poderia ser umas pessoas de dizer: poxa, a gente trabalhou junto, a gente é uma equipe, vamos fazer um termo igual [...] porque eu via os cara no final do ano, três mês, quatro mês, era os cara com um carro novo e nós andando a pé. Então eu sentia um pouco de humilhação nessa parte.

Leonardo: Porque eu descobri depois também. Sei lá, você fechar um cachê e aí, conversando com o seu amigo de elenco, ele fala quanto tá ganhando. Você fala: nossa, peraí, eu tô ganhando bem menos que isso. Por que que eu tô ganhando bem menos do que isso?

Para o entrevistado que é artista profissional, a estigmatização da pessoa com nanismo repercute na valorização do trabalho por ele realizado. 
Leonardo: Por exemplo, esse ano eu recusei fazer uma campanha publicitária para a [emissora de TV], que era uma campanha de Natal. [...] Me ligaram oferecendo um valor ridículo, primeiro de tudo (riso), que é uma desvalorização do mercado. Isso também é uma coisa que eu luto. Assim, não aceitar trabalhos que... ah, ele é anão, ele não é ator. Aí te oferece um cachê abaixo de um ator que tá ali do seu lado, sabe? Não enxergam a gente como um ator profissional. Enxergam a gente como o anão. Vamo oferecer metade do que a gente tá pagando pro ator que tá ali. E não é bem assim, né? A gente é ator tanto quanto, a gente tá ali no mesmo tempo, gravando o mesmo período e fazendo as mesmas coisas que qualquer outro ator. E aí eu recusei essa proposta. Primeiro por conta do valor, que eu achei ridículo, por se tratar de uma empresa muito grande, e, segundo, o personagem era um duende de Papai Noel.

Ao mesmo tempo em que os entrevistados falaram sobre a humilhação nestes trabalhos, também relembraram com saudosismo a época em que estavam na mídia e tinham a oportunidade de muitos convites para shows com valor de cachês mais altos que no momento.

Foi uma época de prosperidade material.

Pedro: Eu falo isso prá um monte de gente, porque tudo o que eu conquistei na vida foi com o meu, digamos aí, a minha imagem.

Ricardo: Ah, era bom demais [...] Eu gostava. Porque dali saía um salário prá mim pagar as minhas contas, sair prá brincar [...] Era o tempo em que eu ficava o mais feliz da vida. Foi quando eu consegui o dinheiro pra comprar todas as coisa pra minha mãe. Só de moeda de um real. Eu comprava as coisa, ia depositando ali no cofrinho.

Quanto à humilhação em um ambiente corporativo, apenas um dos entrevistados relembrou que num processo de seleção do qual fez parte, partiu do próprio responsável pelo departamento de Gestão de Pessoas atos humilhantes.

Joaquim: Aí a senhora lá do RH [...] A mulher chegou prá mim e falou assim: você alcançou apertar o botão do elevador? Eu falei: sim, senhora. [...] Aí ela falou: você é pequeno mesmo, né? [...] Ela fez a entrevista [...] Aí, de repente, quando eu terminei tudo [...] um segurança lá dela pegou e me chamou. [...] O segurança falou: vem cá um pouquinho. [...] Aí chamou eu prá ir no banheiro. [...] Eu cheguei lá no banheiro, meu, o cara falou assim [...] Agora faz a versão número dois, não precisa tirar a calça não, só abaixa, tudo, fica de cócoras também [...] Eu nem acreditei. Eu falei... Porque isso já era em 2006 prá 2007. [...]Teve uma situação uma vez que eu candidatei pra uma vaga de auxiliar de serviços gerais. A senhora que tava lá, do RH, né? Veio e olhou a minha ficha. Meu, ela riscou, fez uma cruz na minha ficha, tipo... Só faltou ela rasgar a ficha. Tipo assim: prá aqui, a gente não tem essa vaga. Eu sabia. Tem coisa que não precisa você falar. A gente não é idiota. Mesmo daquela idade, sem conhecimento nenhum... Porque me deu vontade de falar: eu sabia que isso ia acontecer. Eu já sabia meu. Porque quando eu ia, que a empresa precisava, aceitava de carteira branca, sem registro, a pessoa inventava lá e falava assim: [...] as coisas aqui são muito altas, [...] você não vai alcançar [...] Ou, às vezes, as pessoas mesmo falavam assim: ah, você tem que ganhar dinheiro, trabalhar em circo.

Todas estas formas de rebaixamento do valor social de um indivíduo com nanismo no trabalho, ferindo sua honra, dignidade, status, afeta a capacidade das pessoas atingidas de 
desenvolverem, sem conflitos, uma autorrelação de respeito e de valorização das próprias capacidades, dificultando o desenvolvimento da sua autoestima. Neste âmbito, as possibilidades de autorrealização ficam comprometidas pela invisibilização e desvalorização do trabalho que realizam. Segundo Honneth (2003), as formas de reconhecimento do amor, direito e solidariedade constituem dispositivos de proteção intersubjetivos a partir dos quais se assentam as condições da liberdade externa e interna para uma realização de metas individuais de vida.

Quanto à percepção de preconceito, alguns entrevistados que trabalhavam em atividades não estereotipadas, em empresas de grande porte, afirmaram, num primeiro momento, que nunca perceberam qualquer atitude que configurasse preconceito. A receptividade e o tratamento respeitoso dispensado, desde o processo de contratação, assim como a paridade de tratamento em relação aos demais funcionários, foram ressaltados.

Ney:Talvez o preconceito, ou eu não tenha percebido ou, talvez, não ficou muito claro. Talvez velado. Ou talvez não existiu. Porque foi uma coisa natural. [...] Eu tive muito apoio. E a cultura da [...] aqui você tá como cota, mas eu não vou te tratar como cota. Não deu certo, você sabe o que acontece. Isso não é falado, mas isso você percebe. E eu já vi isso acontecer. Então assim, você vai entregar, o que você tem prá entregar.

Joaquim: E o engraçado é isso, que eu falei assim: meu, será que esse cara vai tirar o sarro de mim? Todo mundo me respeitou sabe. Às vezes, a gente fala: é chão de fábrica, né? Não, não teve nenhum. Sempre me ajudaram, falaram: oh, o que você precisar, tudo, aqui.

Leonardo: Não percebia olhares. Eu tô tentando lembrar do primeiro dia, quando eu cheguei, prá ver se teve algum estranhamento, alguma coisa, mas... não.

Após algum tempo falando sobre este assunto, algumas lembranças de situações que possivelmente poderia ter havido preconceito, foram apontadas:

Ney: Aí no colégio [...] será que vai dar certo? E eu pensei: vai dar certo [...] E eu fui dar aula, prá criançada, num primeiro momento. Normal. No final do ano eles comentam. E aí eu vou dar aula para os adultos, que não é diferente. Ou, que a surpresa é maior. Eles confessam no final do ano: olha, quando eu vim estudar com você eu pensei que o meu professor era uma pessoa alta. [...] No colégio cria-se a primeira surpresa, o primeiro olhar... Teve um menino que ele tá de costas e quando ele gira me vê ele dá um grito: O que que é isso? Que no imaginário dele isso não existe. Aí depois a convivência [...] Mas tem a surpresa, tem o fator surpresa [...] você pensa que vai ganhar mais? [...] Mas sabe ... Fica, fica, será que vai dar conta? Aí vem o preconceito.

Marcela: Há casos, mas não fica explícito, que duvidam da nossa capacidade. [...] por a gente ser deficiente, acho que isso é uma coisa que acontece com todos, duvidar da capacidade, se a gente é capaz de fazer isso. [...] No final, as pessoas sempre duvidam da gente.

Leonardo: Então eu acho que ainda é uma barreira muito grande. Assim, a primeira impressão é: ele é um anão. O quê que ele pode e o quê que ele não pode fazer? 
Para Miller (1987), a discriminação no emprego pode se dar de maneira sutil porque em comparação à outras deficiências, o nanismo não produz as desvantagens tradicionais, o que cria uma tensão conceitual, pois a discriminação pode estar mais relacionada à diferença física em si do que com a falta de habilidade ou prejuízo percebido. Segundo Kruse (2003), na ordenação da interação social, as pessoas julgam quem pertence a determinadas categorias e a quais espaços elas pertencem. A associação entre idade e altura que pessoas de estatura mediana costumam fazer pode se tornar confusa ao encontrar uma pessoa com nanismo nos espaços públicos, de modo que elas podem ser percebidas como infantis ou muito mais jovens do que realmente são. Vistas como infantis, são percebidas inicialmente como dependentes e menos responsáveis, o que pode leva-las a experimentarem dificuldades como profissionais. Suas características físicas podem desafiar as representações públicas do espaço de atuação profissional e serem percebidas como menos capazes e discriminadas em razão disso.

João: [...] você não vê ele numa novela da Globo como protagonista ou como fazer um teatro sem ser anão. [...] Me mostra um na televisão que é jornalista, que é apresentador, que é repórter... não existe.

A função que ocupam na empresa, sem contato direto com o cliente, foi apontada como sendo uma provável forma de preconceito. Para Ablon (1988), pessoas com nanismo podem ficar relegadas a posições de trabalho em que não seja necessário lidar com o público, o que deixa implícito que a sua aparência física está em desacordo com a imagem que a corporação esteja tentando projetar para o público. Mesmo que o tamanho não tenha nada a ver com a realização da atividade de trabalho, características como idade, altura, sexo, aparência física, permanecem influenciando o lugar de trabalho das pessoas. Como sugere Kruse (2003), uma interseção incomum entre idade e altura pode provocar a aparência de que estariam fora do lugar, deslocando-as para lugares e espaços específicos onde as expectativas não satisfeitas de altura poderiam frustrar a ideia de competência para o trabalho realizado.

Leonardo: Atrás do balcão, sem contato com cliente, ou contato somente via telefone. Não tinha, pelo menos não me lembro de ninguém que tava em um cargo superior ou que tinha um cargo que lhe desse diretamente assim com o cliente, visivelmente na pessoa física. Era sempre telefone e computador.

No mercado de trabalho artístico, o preconceito se manifesta mais claramente quando a pessoa com nanismo que é ator, se inscreve para trabalhos que não são estereotipados e tem as mesmas pretensões salariais que qualquer outra pessoa na mesma função.

Leonardo: Porque é um mercado ainda muito preconceituoso [...] Talvez, até mais do que o mercado... O artístico ainda enxerga o anão como uma figura cômica. Não é maquiado isso, é 
tipo: vamos chamar o anão prá fazer o papel de duende, vamos chamar o anão prá fazer o papel de bobo da corte; vamos chamar o anão prá... É vamos chamar o anão. Não é nem chamar o ator que tem nanismo... Não! Vamos chamar o anão. [...] Eu acho que ele enxerga assim: a pessoa com nanismo não é ator. É o anão que a gente precisa prá cena. Então, não vamos pagar um cachê de ator, vamos pagar um cachê de participação, de figuração, sei lá [...] Talvez, se eu falasse: ah, eu tenho nanismo, sou ator, tal... iam falar: não tem personagem. [...] Mas eu não tô me inscrevendo pra algum personagem com nanismo. Eu tô falando que eu tenho nanismo, mas eu sou ator, eu quero concorrer a personagens comuns, que todo mundo tá concorrendo. Talvez eu teria sido limado. Nem chamado pro teste eu teria sido.

Para Goffman (2002), o estigma é um atributo que desacredita um indivíduo, reduzindo-o de uma pessoa inteira a uma pessoa contaminada. O que é conceituado pelo autor, é exemplificado pelo relato de um dos participantes, ao mencionar experiências em ambientes organizacionais em que sua identidade social despertava medo.

Joaquim: [...] E tinha uma menina nessa outra empresa que eu trabalhava, tinha uma menina que ela tinha medo. Aí o meu chefe foi e falou com ela. [...] quando eu encostava perto dela, ela saía. Aí depois, sabe, foi interessante, ela mudou de setor, de lugar, sei lá prá onde, depois ela me encontrou no elevador. Eu falei: não era você que tinha medo de mim? Ela falou: acabou. [...] Só que aí eu tentava evitar de passar. Mas, às vezes... teve um dia que nós cruzamos. Eu falei: ah meu Deus do céu, desculpa.

Em ambientes corporativos, geralmente existe um Código de Ética que regula a conduta dos seus funcionários, favorecendo o desenvolvimento de uma cultura organizacional de respeito mútuo. A necessidade de cumprir a cota com a contratação de pessoas com deficiência, fez com muitas delas preparassem seu ambiente, investindo no desenvolvimento de uma cultura organizacional voltada para a diversidade. Como apontado por CarvalhoFreitas, Toledo, Nepomuceno, Suzano e Almeida (2010), as organizações realizam atividades de sensibilização visando facilitar o processo de socialização de pessoas com deficiência.

Joaquim: políticas na empresa que evitam o desrespeito [...] Porque a pessoa, se haver alguma coisa ali, a pessoa sabe que se ela for na justiça, que é mais fácil dela ganhar, mais fácil porque a empresa tá assim preocupada sabe, em não denegrir a imagem dela, tudo. Então ela procura fazer o máximo [...] Respeita, tudo, em todos os sentidos.

Leonardo: Ah, o que rola muito também, por exemplo, eu descobri isso, que a minha gestora, quando me contratou, ela avisou antes toda a equipe que teria um funcionário com nanismo. Então as pessoas já ficam meio armadas né, preparadas para receber uma pessoa com nanismo. E não recebe espontaneamente [...] não fazem as perguntas naturais, que todo mundo tem, as curiosidades que todo mundo tem. E aí a pessoa se arma, se bloqueia também, fica naquela: não posso falar que ele é anão, vou tratar de igual prá igual.

Os entrevistados que trabalhavam em pequenas empresas relataram que não percebiam a possibilidade de ascensão hierárquica, ainda que houvesse um esforço permanente para demonstrar maiores capacidades para o trabalho e ainda que fossem responsáveis pela atividade principal da empresa, o que pode indicar que apenas empresas de grande porte, que 
normalmente têm uma política de carreira que contempla a todos os funcionários, sem discriminação, respeitam e contemplam o desenvolvimento deles.

Ney: Porque chegou um momento do colégio que a diretora queria que eu ficasse no corredor, vigiando sala [...] Porque a mulher começou a me tirar da biblioteca pra eu ir pro corredor, ficar lá! [...] Eu estudei a vida inteira prá fazer papel de vaso? Papel de vaso eu vou fazer no teatro que eu ainda vou tá ganhado por isso.

Marcela: Eu sempre fui muito dedicada, mas eu não sei se estava diretamente ligado por eu ser pequena. A impressão que dá é que eu superei a expectativa que ele tinha. [...] Então eu sempre tento dar o meu melhor. Acho que até por eu ter aprendido muita coisa sozinha na minha adolescência, da minha profissão, eu sinto essa necessidade de provar que eu posso ir muito mais além [...] A marca, tudo funcionava na minha linguagem, rede social, tudo. Então, ele sentia que não podia me perder, mas ele tinha dificuldade, medo de investir em mim. [...] Eu sinto essa necessidade, de que eu tenho me esforçar, de que eu tenho que dar o meu melhor, mais, do que se eu não tivesse, pra me destacar, porque senão eu vou ser vista como uma pessoa igual ou até inferior por conta disso [...] Sabe aquele termo que estagiário que tem função de funcionário normal e faz trabalho de vinte ao mesmo tempo pra receber pouco? Começou a acontecer isso. A empresa começou a crescer muito rápido e muita coisa começou a ficar sobrecarregada prá mim. [...] As duas empresas que eu trabalhei não tinha plano de carreira. Então eu não sei como que é crescer numa empresa, se o mercado de trabalho deixa a gente crescer ou se a gente só fica ali, estagnado. Eu não sei como funciona. Mas até onde sei, acho que isso não é uma barreira tão grande pelas pessoas que eu conheço.

Reunir as qualificações desejáveis não se mostrou suficiente para garantir uma oportunidade de trabalho com registro na Carteira de Trabalho para a participante mais jovem deste estudo, nem mesmo para aqueles que acumularam muitos anos de trabalho, em muitas empresas, sem jamais ter um registro na carteira de trabalho. Por mais que trabalhassem na atividade principal da empresa, a falta de formalização do contrato de trabalho, apesar de ser percebida por eles como uma forma de injustiça, também pode ser um indício de preconceito, não por considerá-la uma trabalhadora desacreditável, mas, talvez, por não colocá-la em pé de igualdade de uma pessoa sem deficiência.

Marcela: A única designer era eu. Não tem como crescer ali. Eu tinha como fazer a empresa crescer, mas eu sempre ia ficar na mesma? Então isso é complicado. [...] Meu chefe, em alguns casos, já falou: olha, você supera qualquer funcionário que eu já tive. Ele sempre falou que eu fui a melhor funcionária que ele teve [...] Ela tinha que assinar a minha carteira. Ela tinha que me registrar né, dar meus vales, dar seguro de saúde, FGTS, tudo. Ela nunca disse nada. Nunca assinou a minha carteira. [...] Aí eu comecei a cobrar com o pessoal do RH e aí o pessoal do RH falava: olha, eu não sei o quê que elas querem com você; não sei se elas querem te contratar; não sei, elas não falam nisso. Eu continuei trabalhando. [...] ó eu que não era registrada. Só tinha... só mesmo era eu. 


\subsection{Possibilidades de reconhecimento no trabalho}

A seguir, serão apresentadas as narrativas dos entrevistados no que se refere às possibilidades de reconhecimento já ativas ou que ainda desejadas.

\subsubsection{Reconhecimento}

Sob a Lei de Cotas, muitas pessoas com deficiência puderam acessar o mercado formal de trabalho, o que possibilitou, para aqueles com maior nível de escolaridade, mobilidade ocupacional. É importante demarcar as condições históricas deste presente já que, mesmo pelo viés de obrigatoriedade da lei, foram abertas possibilidades do direito ao trabalho em ocupações não estereotipadas, trazendo mudanças para aqueles que já trabalhavam no mercado informal e para pessoas com nanismo mais jovens, que já puderam vislumbrar um projeto de vida de trabalho e não apenas uma forma de sustento. Foram estas condições, de extensão de direitos a minorias, que aperfeiçoaram normativamente as relações de reconhecimento no âmbito do trabalho para pessoas com deficiência. Como assinala Honneth (2003), se a experiência de desrespeito se constitui como uma negação de reconhecimento, no âmbito dos fenômenos negativos, também devem ser encontradas formas de obter o reconhecimento, no domínio dos fenômenos positivos. Para ele, o sentimento de dignidade e autorrespeito internalizados são resultado de uma relação intersubjetiva onde se dá o reconhecimento.

Foram estas possibilidades de reconhecimento, já obtidas ou desejadas, que os entrevistados relataram nas entrevistas. Para eles, ser reconhecido como um membro legítimo da organização social do trabalho lhe permite autorrealização. Este reconhecimento é expresso na adequação de um ambiente de trabalho e colocação em uma função que atenda às suas necessidades ergonômicas e de realização das atividades. Para Honneth (2003), nestas relações solidárias, a tolerância e o interesse para com a particularidade de cada pessoa permitem a estima simétrica entre sujeitos individualizados e autônomos.

Ney: [...] agência me ligava três ou quatro vezes [...] qual o tamanho da sua perna? [...] Prá quê? Prá comprar uma cadeira adaptada. [...] Móveis novos e o único móvel que vai aqui desse prédio é a minha cadeira.

Joaquim: Aí eu peguei e fui trabalhar na expedição. [...] Mas aí depois o pessoal foi entendendo e colocava eu pra conferir as caixinha pequena [...] Que nem lá na metalúrgica mesmo, né? Eu ficava assim no balcão, atendendo o pessoal. Aí veio o pessoal da segurança e 
falou assim: você vai ter que fazer um banquinho [...] O quê que eles fizeram? [...] tipo de uma escada.

Leonardo: Mas quando eu entrei nas empresas, foi uma relação muito boa. Eles procuraram entender quais eram as minhas necessidades [...] As três compraram apoio de pé, pra minha altura, né? Com regulagem. [...] Então eles tinham muita preocupação com postura, com Ergonomia, essas coisas. Compraram uma cadeira especial.

Em empresas de grande porte, a possibilidade de ascensão profissional se tornou uma realidade para alguns entrevistados. O cumprimento das exigências de qualificação, como a graduação no Ensino Superior, foi uma condição exigida, o que lhes impulsionou a retomar sua trajetória educacional para ter um curso de nível superior e assim atender aos requisitos para promoções.

João: Eu entrei, fiz a faculdade, me formei, fui promovido [...] Eu era analista, fui pra Júnior e fui para Pleno.

Joaquim: [...] como eu não tinha faculdade, eu não podia ter promoção. Agora que eu terminei, agora sim [...]E nessas empresas grandes a gente é avaliado. [...] eu vou pegar o certificado agora. [...] quem sabe no ano que vem, se Deus quiser, eu tenho uma promoção.

Para Barnes e Mercer (2005), mesmo que cidadania esteja associada a um agente econômico, um vínculo de emprego remunerado também é importante pelos seus efeitos psicológicos e sociais. Segundo Hartmann e Honneth (2009), avanços podem acontecer quando o Estado promove uma política social e econômica capaz de regular institucionalmente normas que favoreçam o reconhecimento a integrantes da sociedade antes colocados à margem da inserção profissional. Como exemplo desta política de Estado, temos a Lei de Cotas e os seus efeitos para alguns entrevistados:

João: Sou um cara profissional, trabalho numa baita de uma empresa. Se for ver, uma das melhores empresas no ramo privado que tem no Brasil.

Ney: E aí eu vim prá cá e me sinto realizado profissionalmente e mais pessoalmente. Porque aí você lida com o amplo, com o grande, com o gigante, com o macro. Deixo o micro, prá ir pro macro. [...] É da conquista. Como eu dei aula trinta anos, eu sempre me imaginava indo de manhã para um trabalho. Olha que louco. Porque tu vê todo mundo indo né. E você trabalha no bairro. Foi importante, é bacana. [...]: E vim para uma multinacional. Um ambiente mais agressivo, corporativo, hostil, que todo ambiente de escritório é assim [...] Porque o mais importante não é o trabalho em si, mas é o que proporciona o meu trabalho. O meu trabalho me leva prá praia, o meu trabalho compra, quita meu apartamento, o meu trabalho vai tirar minha carta de motorista, o meu trabalho vai comprar um carro, o meu trabalho vai me propor viajar. É esse lance. E aí, claro, das pessoas que vão tá envolta disso tudo. Não é o trabalho em si.

A autorrealização mencionada pelos entrevistados se refere à possibilidade de ser reconhecido positivamente no interior de uma coletividade, criando condições intersubjetivas para uma vida bem-sucedida, como assinala Honneth (2003). Para ele, através da experiência 
do reconhecimento jurídico na esfera dos direitos, a pessoa se sente capaz de participar da vida social organizada e regulada institucionalmente. Essas relações geram autorrespeito, uma “consciência de poder se respeitar a si próprio, porque ele merece o respeito de todos os outros" (Honneth, 2003, p. 195).

Quando as vias de acesso ao emprego encontram-se abertas, outros fatores relacionados à recusa do reconhecimento podem se constituir paulatinamente no ambiente organizacional. Se algumas empresas estimulam o desenvolvimento profissional como condição para a promoção, em outras a relação pode ser ambivalente, com práticas que valorizam o resultado do trabalho realizado pelo contratado com nanismo, ao tempo em que colocam limitações para sua ascensão, relegando-o a posições iniciais na estrutura hierárquica. Para um dos entrevistados, o pouco tempo de trabalho em empresas que o contrataram não deixou clara possibilidade de ascensão. O seu bom desempenho, medido pelo aumento de tarefas, de responsabilidades, não foi suficiente para que ele vislumbrasse a transformação disso em alguma forma de ascensão. Outros trabalhadores com deficiência destas empresas, com mais tempo de contratação, permaneciam na mesma função inicial, o que pode indicar que essa limitação é estendida a todo o grupo de funcionários com deficiência.

Leonardo: E acho que eu consegui me destacar em pouco tempo na empresa [...] Eles começaram a me dar demanda, começaram a me dar mais trabalhos. Eles viram que a minha capacidade intelectual não tinha nada relacionada à capacidade física e no início era uma demanda de trabalho. Passou dois meses, já era outra [...] Em todas as empresas que eu passei eu sinto que o curto tempo que eu permaneci nelas, a responsabilidade cresceu muito [...] A única questão era a falta de oportunidade de crescimento. Confiavam no trabalho, mas queriam te manter ali, porque o salário é menor, porque isso tá cumprindo a cota, tá ok. Acho que é a oportunidade de crescimento era muito limitada pras pessoas com deficiência [...] Surgiam mais trabalhos pra mim, surgia uma responsabilidade maior, mas eu não via uma possibilidade de crescimento. Talvez pelo curto tempo. Pode ser que se eu permanecesse mais, haveria alguma ascensão, mas comparada a outras deficiências que eu via lá que já estavam lá há alguns anos... já tava dois, três anos, quatro anos, sempre no mesmo cargo. Isso me preocupava um pouco.

A ascensão profissional em trabalhos de artes cênicas não se caracterizava propriamente por oportunidades de desempenho em papéis como protagonistas ou desafiadores na aplicação de suas capacidades, nem mesmo por uma mudança para um contrato de trabalho registrado. Esta ascensão se caracterizava pela participação em mais programas de TV e eventos externos. Não era, propriamente, uma ascensão na carreira, mas sim mais trabalhos igualmente desprotegidos, desempenhando os mesmos papeis 
estereotipados, mas que lhes rendiam fama. Por isso, especialmente aqueles com experiências de trabalho mais precárias, denominaram como reconhecimento o fato de serem identificados nos espaços públicos como "celebridade". Para eles, "fama" foi interpretada como reconhecimento no trabalho.

Ricardo: [...] até hoje, quando a gente passa na rua, a gente é bem conhecido mesmo. [...] Lá no Brás, o pessoal parava nós. [...] eles quase não deixavam nós vir embora. Arrodeando nós pra tirar foto e brincar com nós. Pegava nós e botava no braço. Era um negócio medonho. Era muito engraçado. [...] Você sabe que eu acho é legal. Porque eu ainda tô sendo um anão reconhecido [...] Vinha gente pra comprar eu de Brasília, de todo canto do mundo [...] Poxa, ali pra mim, foi o meu... era o tempo que eu vivi mais feliz na minha vida. [...]Porque assim, tanto eu ganhava mais, como trazia animação prás pessoas que tavam em casa. A gente saía, de casa, a gente saía no portão de casa, era mesmo que um mói de formiga, das criança vir abraçar, tirar foto. Era uma alegria medonha. E eu me sentia muito feliz naquela época. Hoje eu me sinto triste. [...] E o povo grande também, sempre gostaram da gente. Quando eles viam a gente fazer paiaçada na televisão, eles sempre vinham: ah, vamo tirar uma foto, vamo conversar um pouco e brincar. Prá mim, os probrema da gente já... a gente esquecia que tinha probrema.

Para Lima (2009), a inclusão que se dá em um sistema com papéis delineados $a$ priorié um movimento reverso da autonomia, expressa apenas pela liberdade pressuposta pelo mercado. Para Honneth (2003), as transformações socioestruturais ocorridas em sociedades desenvolvidas ampliaram objetivamente as possibilidades de autorrealização, de modo que diferenças individuais ou coletivas foram convertidas em lutas políticas de diversos movimentos sociais. No entanto, o que é exigido nestes movimentos só poderá se concretizar a longo prazo, "quando ocorrerem mudanças culturais que acarretam uma ampliação radical das relações de solidariedade" (Honneth, 2003, p. 280).

Os entrevistados com pouca escolarização relataram o bem-estar psicológico proporcionado pela fama, o que é uma expressão das contradições sociais expressas pelo que Lima (2009) denomina como "reconhecimento perverso", em que as identidades são reduzidas à personagens fetichizadas. Nesta relação perversa, um indivíduo frente ao sofrimento de indeterminação busca reconhecimento de sua personagem em Outro, que reconhece aquele a partir de um ponto de vista reducionista da identidade.

Joaquim: [...] Eu comecei a me empolgar muito com essas coisas, com o que tava... Pra você ver, uma simples pessoa, apesar de que eu não tava sendo uma estrela, né? Mas eu era muito procurado, sabe? Tudo. [...]. Aí eu comecei a avacalhar a minha vida. Comecei a beber, tudo, que a gente se chama, não sei se você sabe, da auto-idolatria [...] Eu comecei a beber, tudo, a faltar nos eventos [...] Me empolguei demais.

Leonardo: Só que o grande problema da televisão, da mídia em geral, do trabalho artístico de grande alcance, não tô nem falando do teatro, até porque essas pessoas nem fazem teatro, essas que aceitam fazer programas de humor... é o deslumbramento, eu acho. É o você sair na rua e ser reconhecido sabe. Isso também conta bastante. Eu vejo que essas pessoas se deslumbram muito porque é conhecido como o anão do Ratinho, ou o anão do Pânico. Você tá na rua e tipo... Olha lá o anão do Pânico! Eu acho que isso causa: olha, eu tô sendo reconhecido, 
negativamente, mas tô sendo reconhecido. Então acaba alimentando essa vontade de estar ali na TV passando prá muitas pessoas te verem. Isso, eu acho que é uma grande questão também porque essas pessoas não param de fazer isso [...] Ao longo de todas as sociedades que já existiram, do Egito Antigo à Idade Média, até hoje. Desde sempre. Mitologia... Nórdica, que a gente tava falando. Mitologia nórdicas de elfos, de duendes, de gnomos, de... é sempre nesse lugar mágico, onírico ou de humor, do cômico, do bobo da corte, do circo. [...] Um povo especial. Do... Teve uma época que foi muito, muito, forte o circo de aberrações né.

Ao se tornarem famosos, as pessoas com nanismo passam a experimentar expectativas sociais diferentes em relação à sua condição de estigmatizado. Se antes da fama eles recebiam notoriedade em razão do estigma, tendo prejuízos sociais em razão disso, com ela, a atenção social se transmuta pelas novas interpretações a respeito de sua identidade, já que agora são "artistas".

Para aqueles que no momento da entrevista trabalhavam apenas com eventos, sem a intermediação de nenhuma agência de trabalho, atendendo diretamente os clientes interessados em seus shows, o preço do cachê e a decisão de fazer ou não o evento, foram apontados como fatores de autonomia no trabalho. As experiências pregressas em trabalhos estereotipados, muitas vezes sob condições humilhantes, faziam-nos considerar a escolha de atender ou não a demanda. Para Honneth (2008), dada a diferenciação entre as formas de trabalho, são os próprios sujeitos, partindo da análise das estruturas de trabalho a qual pertencem no mundo social, que podem estabelecer as exigências morais para suas práticas cotidianas. Para isso, é necessária a voz dos afetados, que colocam o seu mal-estar em cena, pois são eles que reagem às relações de trabalho existentes, uma vez que "[...] nas condições dadas há sofrimento e não apenas predomínio da indiferença, que há luta e exigências não apenas reações de apatia estratégica" (p. 65).

Pedro: Tem muita gente que me chama hoje em dia pra fazer algum tipo de evento [...] Aí eu dou o meu preço. Eu vou por X. Infelizmente, eu não tô na mídia também, mas eu peço de quinhentos a mil real a minha presença. [...] Cada um se vende pelo preço que dá, pra fazer seu trabalho [...] Tem cara que me fala: [...] mas fulano de tal vai por duzentos ou cem. Eu digo: chame ele [...] não tô passando fome [...] Eu falo porque tem cara que quer contratar o cara para trabalhar de dez da manhã às seis da noite ou sete da noite. Prá ficar em pé como um escravo sabe. Não, vou nada, eu não vou.

O entrevistado que tem como profissão ator, a autonomia no trabalho se concretizou ao decidir abandonar os trabalhos em ambientes corporativos, em funções convencionais, para dedicar-se ao que realmente gosta: a carreira artística. A construção desta autonomia, como ele mesmo ressalta, passa por decisões de romper com os papéis estereotipados atribuídos à pessoa com nanismo no teatro e televisão.

Leonardo: E aí começou a me atrapalhar e era o que eu queria ser realmente, era ator, e eu falei: ah, se as oportunidades tão batendo aí na porta, eu não vou fechar a porta prá ela, eu vou sair dessa área administrativa, escritório e vou me jogar no mundo das artes; [...] Eu acho que 
foi adquirida a partir de... a partir do momento em que eu me posicionei pro mercado artístico e falei: não vou mais fazer duendes de Papai Noel, nem gnomos, nem Branca de Neve; vou ser reconhecido pela minha capacidade como ator e como profissional, e eu preciso acreditar em mim mais do que eles. Então, eu vou bancar essa história. Vou falar: meu, eu sou ator, tenho nanismo, sim, mas eu quero concorrer a alguma vaga, eu quero ver se não tem aí como encaixar. E já consegui outros papéis, dessa mesma forma. Esse aí eu mandei não dizendo que eu era anão, não revelando que eu era anão. Fui pro teste, consegui através do teste que criassem um personagem pra mim.

Segundo Lima (2009), na concepção de Ciampa de identidade, o indivíduo não é apenas um receptáculo, um membro da comunidade que incorpora as predicações para dramatiza-las no cotidiano. Ele também propõe novas personagens, reage a esta comunidade e as transforma com suas reações. Se a identidade é metamorfose humana, esta atitude de reação à estereotipia no trabalho artístico, que tenta reduzir a identidade a personagens fetichizadas, pode ser considerada uma luta por reconhecimento.

Para Honneth (2003), num estado de liberdade ou espontaneidade, um indivíduo já não tem bloqueios internos, inibições psíquicas e angústias, e sua confiança passa a ser dirigida para fora, garantindo-lhe segurança na aplicação de suas capacidades. Para esta autorrealização individual, a experiência do reconhecimento intersubjetivo, que depende do seu parceiro de interação, precisa oferecer condições que favoreçam uma autorrelação positiva. Sem autoconfiança a respeito das próprias capacidades e autonomia juridicamente preservada, a eleição espontânea de metas e sua realização, ficam prejudicadas.

Ao falarem sobre as relações de trabalho no ambiente organizacional, os entrevistados ressaltaram o respeito com que são tratados pelos pares e chefias. Para um dos participantes, a atividade de docência, exercida informalmente na comunidade onde mora antes de ter um emprego, até hoje lhe rende a identidade profissional de "professor", interpretado como uma manifestação de respeito. Para outro, a internalização do estigmaproduz uma expectativa de “interação angustiada” (Goffman, 2012. p.27) em situações sociais mistas.

João: Sempre me encararam, me aceitaram e me respeitaram da forma que eu sou.

Ney:[...] porque aonde eu moro, eu sou bastante conhecido. Eu passo: oi professor, bom dia professor, boa tarde professor, boa noite professor, madrugada professor! Eu com orgulho né, porque lá na frente eu vou fazer faculdade de Letras e aí eu posso falar, eu sou professor mesmo.

Joaquim: E o engraçado é isso, que eu falei assim: meu, será que esse cara vai tirar o sarro de mim? Todo mundo me respeitou sabe. Às vezes a gente fala: é chão de fábrica, né? Não, não teve nenhum. Sempre me ajudaram, falaram: oh, o que você precisar, tudo, aqui. [...] eu fiz agora último evento num buffet dum menino [...] eu fiquei tão emocionado porque pela primeira vez eu fui fazer evento e todo mundo me tratou eu com respeito. 
Para Honneth (2003), a ampliação das relações de reconhecimento se dá quando estão embutidas nas experiências intersubjetivas o respeito às possibilidades de universalização e materialização do direito, e as possibilidades de individualização e igualização, pertencentes à comunidade de valores. Portanto, a autorrealização pessoal está intimamente relacionada à criação de estruturas sociais para o reconhecimento intersubjetivo.

Ser chamado de "anão" causa bastante incômodo aos entrevistados, em razão do estigma que esta palavra carrega. Então como gostariam de ser identificados socialmente? Se outros grupos com deficiência, como cegos, surdos, surdos-mudos, cadeirantes, amputados, entre outros, são assim identificados socialmente, então como ficariam as pessoas reunidas sob a condição clínica da acondroplasia?

Ney: A pessoa pequena ela é pequena. [...] Mas o nome é o nanismo mesmo.

Marcela: [...] O que eu sou mais familiarizada é com pequeno. Mas uma pessoa com nanismo pra mim também é tranquilo, baixinha também é tranquilo [...] É até uma dúvida minha, porque isso não se discute. A maioria não gosta.

Joaquim: Se for falar, fala assim: é uma pessoa com nanismo. Eu acho bacana esse nome. Pessoa com nanismo, pessoa de baixa estatura ou pessoa com acondroplasia [...] Porque às vezes fala: ah, a pessoa com acondroplasia. [...] É um nome estranho [...]De baixa estatura. Vai falar assim: mas quem é de baixa estatura? A minha prima tem um metro e cinquenta, ela é baixa estatura. [...]Já a pessoa com nanismo, é uma forma assim carinhosa, mas a pessoa dá um jeito de identificar. [...] Mas eu acho, pessoa com nanismo sabe, eu acho uma palavra exata

Leonardo: algumas pessoas aqui no Brasil se tratam como pequenos. [...] Eu tentei usar esse termo. Às vezes até uso. Mas também me incomoda o fato de falar: ah, você conhece fulano? Que fulano? Ah, ele é pequeno também. Tipo, tá, o quê que é pequeno? Uma criança é pequena, qualquer coisa é pequena. Não é a identidade daquela pessoa. Eu acho que o termo mais correto, mas que é muito longo também, é pessoa com nanismo. Prá mim é o termo mais... que menos ofende, que menos agride e que vem carregado, é pessoa com nanismo. [...] É você. Mas é você, não de uma forma negativa, como o anão vem sendo carregado. Então, eu acho que a pessoa com nanismo, pessoa com deficiência, talvez seja o termo mais correto. E essa questão da pessoa pequena, é um pouco mais fofinha, né? Tentando deixar ela mais fofa, e isso também me incomoda um pouco. [...] Eu acho, eu acho ruim. Eu acho que fica nessa visão fofa, sabe? E o fofo negativo. [...] Não vai te ver como um cidadão, como um adulto, de igual prá igual. [...] Assim que estreou a novela [...] me ligaram prá dar uma entrevista pra... [...] entrevista por telefone, tal. A entrevista foi maravilhosa, eu fiquei superfeliz, assim, das perguntas que ele fez e tal. Aí eu fui ler a matéria. Matéria ficou ótima. [...] e aí a chamada da matéria era: Anão [...] disse inspirar em ator de Game of Thrones. Aí eu falei: ah, então, ele é o ator; eu sou só o anão. Eu ainda não cheguei no patamar de ator. Ele me enxerga só como o anão [...] Isso me incomodou bastante assim, na chamada[...] São meios massacrantes e ofensivos que a indústria colocou, né? Prá divulgação, prá atrair chamariz pra matéria. Mas isso me agrediu de uma forma que toda matéria que tava linda, tava bem construída, bem colocada... Eu falei: nossa, é só essa chamada que destruiu tudo que a gente discutiu e debateu. Porque justamente na entrevista eu falo do estereótipo, eu falo da dificuldade do ator com nanismo de ir na contramão. Falo sobre tudo isso. Sobre a quebra de preconceito e aí ele vai e me coloca uma chamada preconceituosa dessa. 
Conforme o relato dos entrevistados, há palavras que poderiam designar melhor a sua condição de acondroplasia sem carregar a conotação pejorativa do termo "anão", que geralmente cria tensões morais pela forma com que é empregado. Essa pretensão ao reconhecimento intersubjetivo de uma identidade descolada de antigas interpretações culturais pode impelir a uma reivindicação de luta, geralmente encabeçada por instituições de apoio a este grupo populacional, mas vai além, como ressalta Honneth (2003), de uma medida institucionalizada de progresso social, que conduz a um estado de liberdade comunicativa, que se repete de maneira gradativa.

Com o intuito de perpetuar o uso pejorativo da palavra "anão" em meios de comunicação, a LPA (2015) começou a alertar meios de comunicação, na política, esporte na indústria do entretenimento quanto ao seu uso impróprio e nocivo, num esforço de aposentar permanente este termo e juntá-lo a outros igualmente antiquados e prejudiciais que eram utilizados para definir grupos sociais. Do mesmo modo, associações que agora se estruturam em defesa dos direitos das pessoas com nanismo podem também atuar nestes e em outros canais propondo à sociedade reflexões a respeito das lutas no âmbito do reconhecimento. 
Considerações Finais 
Compreender a vida de trabalho de um grupo populacional marcado historicamente pelo estigmatização requer a análise de diversos fatores presentes em suas trajetórias de vida e que constituíram suas possibilidades de existir no mundo. O conjunto de determinações estruturais e restrições sociais que tradicionalmente marcam estudos de trabalhadores com deficiência, neste, ganhou dimensões adicionais, que pesam de forma diferente na preparação e inserção da pessoa com nanismo para o mundo do trabalho.

Muito mais pela diferença física em si, do que pela "deficiência”, a pessoa é percebida e categorizada por aquelas de estatura mediana com base em representações culturais que geram interações mediadas por reações ambivalentes à sua presença. As relações mediadas por uma anatomia que ainda parece rara e que evoca crenças tão antigas, dão forma ao cotidiano de cada uma, deixando a pessoa exposta a um enredo de interpretação e julgamento que culmina em atitudes sociais que vão da rejeição à aceitação, afetando o seu bem-estar emocional.

Com as diversas experiências pessoais de viver com nanismo aqui colecionadas foi possível observar que nem todas experimentam o mesmo grau de opressão e mal-estar psicológico. A biografia, a interseção de identidades, o cotidiano de experiências, o ambiente socioeconômico e cultural ao qual tem acesso, contribuem para que as pessoas experimentem consequências diferentes da estigmatização. As formas que a estigmatização e o preconceito assumem decorrem muito do grau de vulnerabilidade a que o indivíduo está exposto, podendo ser mais opressivas e excludentes quando outros fatores, tais como escolaridade, cor da pele, origem e gênero, se cruzam com os estereótipos sociais.

No entanto, o que há de comum a todas elas é que ainda são alvos de desrespeito, que reproduzem na vida cotidiana humilhação e prejuízos para a autoestima, tanto individual quanto coletivamente, contribuindo para a interrupção da trajetória escolar em alguns casos e o isolamento social como forma de evitar as respostas sociais negativas que ferem sua dignidade e rebaixam sua identidade.

$\mathrm{Na}$ divisão social do trabalho, a força das representações culturais também se faz presente, reproduzindo a categorização de pessoas com nanismo em trabalhos estereotipados voltados à exibição do cômico, risível e exótico. Na ausência de ações afirmativas voltadas para a inserção no mercado de trabalho formal de pessoas com deficiência, estes trabalhos em programas de humor ou em eventos ligados ao entretenimento, constituíam a principal oferta de trabalho oferecida pelo mercado para estas pessoas. Embora não seja recomendável falar em um mercado de trabalho (Oliveira \& Piccinini, 2011), dada a dinamicidade das relações entre indivíduos, instituições e sociedade que nele atuam para oferecer-lhe uma configuração, 
quando se trata deste espaço de relações de trabalho mediadas por esta deficiência, pode-se dizer que a base para o recrutamento é o estigma e o estereótipo a ele associado. Independentemente de a pessoa buscar ou não um trabalho nestes termos, é muito provável que ela receba convites para "atuar" em razão da sua imagem, o que é considerado ofensivo para alguns deles.

O impacto da Lei de Cotas foi positivo para aqueles que conseguiram, mesmo após a contratação, reunir qualificações desejáveis para as organizações. A inserção no mercado formal de trabalho proporcionou a retomada da vida acadêmica para aqueles que ainda não tinham Ensino Superior pois, por orientação da política organizacional de desenvolvimento de pessoas das organizações contratantes, geralmente de grande porte, eles foram incentivados a retomar os estudos e puderam, a partir de então, usufruir de políticas de promoção na empresa. Para estas pessoas, a mobilidade ocupacional, propiciada pela Lei, gerou mobilidade social, pois eles foram abandonando gradativamente os trabalhos em eventos e programas humorísticos, onde descreveram inúmeras experiências de humilhação e desrespeito, e passaram a ser trabalhadores de grandes corporações, aplicando suas habilidades em funções comuns à de outros trabalhadores sem deficiência, elevando seu "prestígio social" e autoestima por se sentirem em pé de igualdade às demais pessoas e sem experimentar, no ambiente organizacional, discriminação. Além disso, a percepção de que são respeitados e valorizados pelo seu trabalho, em um ambiente livre de discriminação, contribui para aumentar sua autoconfiança.

Para aqueles que sempre trabalharam, mas jamais tiveram um emprego, a Lei de Cotas não surtiu efeito. Mesmo se candidatando para vagas onde não havia grandes exigências de qualificação profissional, como auxiliar de limpeza, jamais conseguiram ter um registro em carteira de trabalho. As trajetórias foram marcadas por trabalhos precários, inseguros e de baixos rendimentos, mantendo-os sempre na linha da pobreza. Ao terem como parâmetro experiências de trabalho anteriores muito degradantes, estes participantes classificaram como o melhor período de suas vidas o tempo em que trabalharam em programas humorísticos na TV e em outros eventos. Ainda que narrassem diversas situações em que conscientemente tiveram sua dignidade ferida, tudo era compensado pelos ganhos financeiros obtidos com sua submissão. Eram muitos trabalhos, em muitos eventos que remuneravam em forma de cachês que, ainda que de baixo valor, quando somados, lhes possibilitou comprar itens básicos e, principalmente, a casa própria.

O estigma, comercializado como força de trabalho, continua sendo uma opção para aquelas pessoas com nanismo que desejam conciliar o emprego com eventos, como uma 
forma de complementar a renda, ou a atividade principal, para aquelas que não conseguiram acessar o mercado de trabalho formal e recebem o Benefício de Prestação Continuada (BPC), cujo valor é de um salário mínimo. Seja como complemento, ou como atividade principal, estes trabalhos estereotipados continuam a demandar das pessoas com nanismo a reprodução de antigos espetáculos, onde seus corpos eram exibidos como exóticos e sua posição, como pessoa humana, era degradada para satisfazer um voyeurismo do público. De todos os grupos populacionais, este continua habitando "naturalmente", no imaginário popular, o ambiente do cômico, alimentando expectativas quanto ao lugar que uma pessoa com esta deficiência deveria ocupar. Estas representações, somadas ainda à raridade de pessoas com nanismo em outras ocupações, podem dificultar ou adiar a criação de novas percepções a seu respeito.

Devido à esta dificuldade em superar estes estereótipos sociais que trazem consequências na vida cotidiana, diversos grupos de pessoas com nanismo têm se organizado em associações para reclamarem reconhecimento. Seja entre aqueles que tem um emprego e já não experimentam, no ambiente organizacional, os prejuízos do estigma, seja entre aqueles que tem trabalhos estereotipados, todos têm em comum o fato de serem alvo de olhares e comentários jocosos. Os prejuízos com a estigmatização na realidade social de cada um, individualmente ou em grupo, são tão antigos, comuns e enraizados, que até parecem ser invisibilizados pelas pessoas de estatura mediana e por outros grupos sociais também afetados por outras formas de estigmatização, dados os relatos de experiências relatadas neste trabalho.

Para esta luta, vários autores (Ablon, 1984, 1988; Adelson, 2005b, 2005c) já reuniram dados de pesquisa para demonstrar a importância de divulgar mais informações sobre a acondroplasia para pais e médicos, desmistificando esta condição genética e seus efeitos ao longo da vida da pessoa afetada por ela, de modo a oferecer maior suporte às relações primárias de afeto. $\mathrm{Na}$ esfera jurídica, as bases intersubjetivas para a realização do direito podem assegurar medidas de proteção à dignidade, sobretudo daqueles que estão em situação de maior vulnerabilidade, de modo a evitar que os mesmos se submetam a condições humilhantes de trabalho em âmbito privado, e mesmo público. Como exemplificado na proibição feita pela ONU (Reuters, 2002) da prática de "arremesso de anões", as bases jurídicas podem se antecipar à objetificação de pessoas com nanismo em programas televisivos, e não apenas reagir à uma provocação de um membro desta categoria social que se sentiu ofendida. Com estas condições, os estereótipos sempre perpetrados pela mídia, podem perder espaço para dar lugar a representações de pessoas reais, que exercem as mesmas atividades comuns às de estatura mediana e enfrentam dificuldades similares a elas também, desconstruindo assim, a ideia de uma diferença anatômica maculada. 
Finalmente, com este trabalho, ainda exploratório, pretende-se contribuir com esta luta por reconhecimento, oferecendo subsídios empíricos para a abertura de debates e apontamentos no campo da prática, nos próprios grupos e congressos de pessoas com nanismo, e também no campo teórico, com a introdução do tema trabalho, ainda tão raro nas discussões sobre os fatores sociais implicados na vida de quem é afetado pela especificidade deste processo de estigmatização. Não se teve aqui a pretensão de generalizar os resultados para toda a população com nanismo, dado o baixo número de entrevistados, mas prezar pela análise das narrativas de experiências de vida escolhidas por eles para este estudo.

Importante recordar que quando as primeiras reflexões a respeito desta proposta de estudo foram apresentadas, muitas pessoas se mostraram interessadas na temática e surpresas por jamais terem pensado sobre a vida da população com nanismo. Afinal, é tão difícil encontrar uma delas! Muitas destas pessoas voltaram para comentar sobre fatos do cotidiano que passaram a observar desde então. Falaram da revolta ao receberem convites onde a "atração seria um anão", da indignação por saberem que conhecidos foram assistir um evento famoso de "luta entre anões" no México, da raiva ao receberem vídeos em que pessoas com nanismo dançam para o riso da plateia, da alegria de encontrar uma pessoa com nanismo no metrô e da tristeza de saber que ela é mesmo alvo de muitos olhares e comentários desagradáveis. Foram muitos comentários que reafirmaram a importância de colocar em cena este debate.

Espera-se que este trabalho sirva para mobilizar todos aqueles com deficiência e fisicamente capazes que reconhecem a injúria das representações feitas a pessoas com nanismo em programas humorísticos e em eventos que prezam pela sua objetificação como instrumento para o riso do público. Depois do que foi apresentado aqui, é notório que não está no passado a exibição de pessoas como "aberrações". Nos últimos meses em que trabalhei na escrita desta tese, foi necessário conviver diariamente com um carro de som que anunciava uma "grande atração no Circo de Roma: um homem de quatro pernas". Ainda há muito a fazer para se construir normativamente relações entre pessoas mais éticas. 


\section{Referências}

Abberley, P. (1997). The concept of oppression and the development of a social theory of disability. In L. Barton \& M. Oliver (Eds.), Disability studies: Past present and future. Leeds, England: The Disability Press.

Ablon, J. (1981). Dwarfism and social identity: Self-help group participation. Social Science \& Medicine. Part B: Medical Anthropology, 15(1), 25-30.

Ablon, J. (1984). Little people in America: The social dimensions of dwarfism. New York, NY: Praeger.

Ablon, J. (1990). Ambiguity and difference: Families with dwarf children. Social Science \& Medicine, 30(8), 879-887.

Ablon, J. (2002). The nature of stigma and medical conditions. Epilepsy \& Behavior, 3(6), 29.

Adelson, B. (2005a). Dwarfs: The changing lives of archetypal 'curiosities'- and echoes of the past. Disability Studies Quarterly, 25(3). Recuperado de http://dsqsds.org/article/view/576/753

Adelson, B. M. (2005b). Dwarfism: Medical and psychosocial aspects of profound short stature. JHU Press.

Adelson, B. (2005c). The lives of dwarfs: their journey from public curiosity toward social liberation. New Jersey, NJ: Rutgers University Press.

Almeida, J. A. M. (2006). Sobre a anamorfose: identidade e emancipação na velhice (Tese de Doutorado). Pontifícia Universidade Católica de São Paulo, São Paulo.

Almeida, L. A. D., \& Vilela, E. M. (2011, outubro). Qualificação, inserção e ganhos salariais: estudos sobre pessoas com e sem deficiência no mercado formal de trabalho. In Encontro Anual da ANPOCS, GT 06: Desigualdade e estratificação social, Caxambu, MG, 35.

Antunes, R. (2015). O caracol e sua concha: ensaios sobre a nova morfologia do trabalho. São Paulo, SP: Boitempo.

Araújo Neto, J. A. C. (2013). A filosofia do reconhecimento: as contribuições de Axel Honneth a essa categoria. Kinesis, 5(9) (spe), 52-69.

Arenas, M. C. H., \& Canal, O. M. M. (2016). Personas de talla baja: factores que influyen en la baja autoestima. Revista científica signos fónicos, 2(2). Recuperado de https://www.google.com/url?sa=t\&rct=j\&q=\&esrc=s\&source=web\&cd=1\&cad=rja\&uact $=8 \& v e d=2$ ahUKEwj97K317azgAhVKtlkKHbGiB5MQFjAAegQIBxAC\&url=http\%3A $\% 2 \mathrm{~F} \% 2$ Frevistas.unipamplona.edu.co\%2Fojs_viceinves\%2Findex.php $\% 2 \mathrm{FCDH} \% 2 \mathrm{Farti}$ cle\%2Fdownload\%2F1958\%2F987\&usg=AOvVaw1S0_2ejVQMjtSpuGhGeFXI 
Arregui, S. F. (2008). Percibirse víctima de discriminación y prejuicio social: el caso de las personas con acondroplasia. In J. F. M. Domínguez, C. H. Casal, A. G. Jiménez, \& E. Gaviria (Eds.), Método, teoría e investigación en psicología social (pp. 417-428). Barcelona, ES: Alhambra.

Arregui, S. F. (2008). Reflexiones sobre el significado social de la humillación. Psicologia Política, 37, 29-46.

Arregui, S. F. (2009). El estigma social del enanismo óseo consecuencias y estrategias de afrontamiento (Doctoral dissertation). Facultad de Psicología, UNED, Espanha.

Backstrom, L. (2012). From the freak show to the living room: Cultural representations of dwarfism and obesity. Sociological Forum, 27(3), 682-707.

Bardin, L. (2016). Análise de conteúdo. Lisboa, Portugal: Edições 70.

Barroso, L. R. (2012). Here, there, and everywhere: Human dignity in contemporany law in the transnational discourse. Boston College International and Comparative Law Review, $35(2)$.

Recuperado

de https://lawdigitalcommons.bc.edu/cgi/viewcontent.cgi?referer=https://www.google.com/ \&httpsredir $=1 \&$ article $=1681 \&$ context $=\mathrm{icl}$

Bentes, H. H. S. (2010). A sociedade decente. Avishai Margalit. (Resenha). Direitos Fundamentais \& Justiça, 13, 321-325.

Baujat, G., Legeai-Mallet, L., Finidori, G., Cormier-Daire, V., \& Le Merrer, M. (2008). Achondroplasia. Best Practice \& Research Clinical Rheumatology, 22(1), 3-18.

Bergson, H. (2007). O riso: ensaio sobre a significação da comicidade. São Paulo, SP: Martins Fontes.

Bogdan, R. (1988). Freak show. Chicago, IL: University of Chicago Press.

Bogdan, R., \& Biklen, S. (1994). Investigação qualitativa em educação: fundamentos, métodos e técnicas. Porto, Portugal: Porto Editora.

Bouali, H., \& Latrech, H. (2015). Achondroplasia: Current opinions and future perspective. Pediatric Endocrinology Reviews, 12(4), 388-395.

Brasil (1968). Decreto n. 62.150, de 19 de janeiro de 1968. Promulga a Convenção $n^{o} 111$ da OIT sobre discriminação em matéria de emprego e profissão. Recuperado de http://www.planalto.gov.br/ccivil_03/decreto/1950-1969/D62150.htm

Brasil (1988). Constituição da República Federativa do Brasil. Recuperado de: http://www.planalto.gov.br/ccivil_03/constituicao/constituição.html

Brasil (1991). Lei n. 8.213, de 24 de julho de 1991. Dispõe sobre os Planos de Benefícios da Previdência Social e dá outras providências. Recuperado de http://www.planalto.gov.br/ccivil_03/LEIS/L8213cons.htm 
Brasil (1999). Decreto $\mathrm{n}^{\circ}$ 3.298, de 20 de dezembro de 1999. Dispõe sobre a Política Nacional para a Integração da Pessoa Portadora de Deficiência, consolida as normas de proteção, $e$ dá outras providências. Recuperado de http://www.planalto.gov.br/ccivil_03/decreto/D3298.htm

Brasil (2001). Decreto $\mathrm{n}^{\mathrm{o}}$ 3.956, de 8 de outubro de 2001. Promulga a Convenção Interamericana para a Eliminação de Todas as Formas de Discriminação contra as Pessoas Portadoras de Deficiência. Recuperado de http://www.planalto.gov.br/ccivil_03/decreto/2001/D3956.htm

Brasil (2004). Decreto $\mathrm{n}^{\circ}$ 5.296, de 2 de dezembro de 2004. Regulamenta as Leis nos 10.048, de 8 de novembro de 2000, que dá prioridade de atendimento às pessoas que especifica, e 10.098, de 19 de dezembro de 2000, que estabelece normas gerais e critérios básicos para a promoção da acessibilidade das pessoas portadoras de deficiência ou com mobilidade reduzida, e dá outras providências. Recuperado de http://www.planalto.gov.br/ccivil_03/_Ato2004-2006/2004/Decreto/D5296.htm

Brasil (2017). Lei n. 13.472. de 31 de julho de 2017. Institui o Dia Nacional de combate ao preconceito contra as pessoas com nanismo. Recuperado de http://www.planalto.gov.br/ccivil_03/_ato2015-2018/2017/lei/L13472.htm

Cançado, M. A. P. (2006). A inclusão de pessoas com deficiência no mercado de trabalho: análise e avaliação do posto SINE/CAADE/MG. In Seminário Internacional Sociedade Inclusiva PUC Minas: Impasses e avanços, Belo Horizonte, MG, IV.

Canossa, C. (2014, 8 de agosto). Como é a lucha libre mexicana? Tradição tem mais de 100 anos no país. Recuperado de https://super.abril.com.br/mundo-estranho/como-e-a-luchalibre-mexicana/

Cardoso, R., Ajzen, S., Santos, K. C. P., Fernandes, L. M. P. D. S., Costa, C., \& Oliveira, J. X. (2009). Características cranianas, faciais e dentárias em indivíduos acondroplásicos. Revista do Instituto de Ciências da Saúde, 27(2), 171-175.

Carrascoza, J., Casaqui, V., \& Hoff, T. (2010). O consumo da diferença: corpo e trabalho nas narrativas do "Portal da Superação". Comunicação, Mídia e Consumo, 7(20), 191-214. Recuperado de http://revistacmc.espm.br/index.php/revistacmc/article/view/281

Carvalho-Freitas, M. N., Toledo, I. D., Nepomuceno, M. F., Suzano, J. C. C., \& Almeida, L. A. D. (2010). Socialização organizacional de pessoas com deficiência. $R A E, 50(3), 264-$ 275.

Castel, (1998). As metamorfoses da questão social: uma crônica do salário. Petrópolis, RJ: Vozes.

Chaudhary, V., \& Bano, S. (2012). Imaging in short stature. Indian Journal of Endocrinology and Metabolism, 16(5), 692-697.

Chiesse, D. R. de P. (2014). O arremesso de anões e o "novo humor" na televisão brasileira: uma análise do programa "Pânico" sob a ótica da dignidade da pessoa humana. In 
Encontro Nacional do CONPEDI: (Re) Pensando o Direito, Desafios para a construção de novos paradigmas. Universidade Federal de Santa Catarina. Florianópolis, SC, XXIII.

Cimpa, A. C. (2005). A estória do Severino e a história da Severina: um ensaio de Psicologia Social. São Paulo, SP: Brasiliense.

Conroy, C. (2012). Freaks and not freaks: Theatre and the making of crip identity. Lambda Nordica. 168-193. Recuperado de http://www.lambdanordica.se/wpcontent/uploads/Conroy-LN12_12.pdf

Courtine, J. J. (2008). O corpo anormal: história eantropologia culturais da deformidade. In A. Corbin, J. J. Courtine, \& G. Vigarello (Orgs.), A história do corpo (pp. 253-340). Rio de Janeiro, RJ: Vozes.

Crocker, J., \& Major, B. (1989). Social stigma and self-esteem: The self-protective properties of stigma. Psychological Review, 96(4), 608-630.

Cunha, J. (2015, 14 de setembro). Séries e programas de TV aquecem a contratação de anões para festas. Recuperado de https://www1.folha.uol.com.br/cotidiano/2015/09/1681320series-e-programas-de-tv-aquecem-a-contratacao-de-anoes-para-festas.shtml

Declaração Universal dos Direitos Humanos (1948). Adotada e proclamada pela Assembleia Geral das Nações Unidas (resolução 217 A III) em 10 de dezembro 1948. Recuperado de https://www.unicef.org/brazil/pt/resources_10133.html

Departamento Intesindical de Estatística e Estudos Socioeconômicos [DIEESE] (2015). Anuário do Sistema Público de Emprego, Trabalho e Renda 2015. Recuperado de: https://www.dieese.org.br/anuariodosistemapublicodeempregotrabalhoerenda/anuarioSist Pub.html. Em 16 set. 2018.

Departamento Intesindical de Estatística e Estudos Socioeconômicos [DIEESE] (2016). Anuário dos Trabalhadores: 2016. (12a ed.). São Paulo. Recuperado de https://www.dieese.org.br/anuario/2017/anuariodosTrabalhadores.html

Fernandes, L., \& Barbosa, R. (2016). A construção social dos corpos periféricos. Saúde e Sociedade, 25(1), 70-82.

Fernández, S., Branscombe, N. R., Gómez, Á., \& Morales, J. (2012). Influence of the social context on use of surgical-lengthening and group-empowering coping strategies among people with dwarfism. Rehabilitation Psychology, 57(3), 224-235.

Fernández, S., Branscombe, N. R., Saguy, T., Gómez, Á., \& Morales, J. F. (2014). Higher moral obligations of tolerance toward other minorities: An extra burden on stigmatized groups. Personality and Social Psychology Bulletin, 40(3), 363-376.

Fernández, S., Saguy, T., \& Halperin, E. (2015). The paradox of humiliation: The acceptance of an unjust devaluation of the self. Personality and Social Psychology Bulletin, 41(7), 976-988. 
Fordham, B. A. (2007). Dangerous bodies: freak shows, expression, and exploitation. UCLA Entertainment Law Review, 14, 207-242.

Frade, L. Y., Oliveira, J., \& Jesus, J. A. L. (2012). Acondroplasia: diagnóstico clínico precoce. Revista Brasília Médica, 49(4), 302-305. Recuperado de https://www.google.com/url?sa=t\&rct=j\&q=\&esrc=s\&source=web\&cd=3\&cad=rja\&uact $=8 \& v e d=2$ ahUKEwiD0fLT3KXgAhVBHrkGHdpLCN4QFjACegQIBxAC\&url=http $\% 3$ A\%2F\%2Frbm.org.br\%2Fexportpdf\%2F131\%2Fv49n4a12.pdf\&usg=AOvVaw2a9iWfqMzhvpf7qII0tL3i

Furtado, O. (2004). Trabalho e subjetividade - O movimento da consciência do trabalhador desempregado. In L. Dowbor, O. Furtado, L. Trevisan, \& H. Silva (Orgs.), Desafios do trabalho. Petrópolis, RJ: Vozes.

Garcia, V. G. (2010). Pessoas com deficiência e o mercado de trabalho: histórico e o contexto contemporâneo (Tese de Doutorado). Universidade Estadual de Campinas, Campinas, SP. Recuperado de http://repositorio.unicamp.br/bitstream/REPOSIP/286387/1/Garcia_ViniciusGaspar_D.pd $\mathrm{f}$

Gerber, D. A. (1992). Volition and valorization in the analysis of the "careers" of people exhibited in freak shows. Disability, Handicap \& Society, 7(1), 53-69.

Gerber, David A. (1996). The "careers" of people exhibited in freak shows: The problem of volitionand valorization. In R. G. Thomson (Ed.), Freakery: Cultural spectacles of the extraordinary body (pp. 38-54). New York, NY: New York University Press.

Gilbert, P. (1997). The evolution of social attractiveness and its role in shame, humiliatioin, guilt and therapy. British Journal of Medical Psychology, 70, 113 -147.

Goffman, E. (2012). Estigma: notas sobre a manipulação da identidade deteriorada. Rio de Janeiro, RJ: LTC.

Gonçalves Filho, J. M. (1998). Humilhação social: um problema político em Psicologia. Psicologia USP, 9(2), 11-67.

Gonçalves Filho, J. M. (2003). Problemas de método em Psicologia Social: algumas notas sobre a humilhação política e o pesquisador participante. In A. M. B. Bock (Org.), Psicologia e compromisso social (pp. 193-239). São Paulo, SP: Cortez.

Gonçalves Filho, J. M. (2007). Humilhação social: humilhação política. In B. P. Souza (Org.), Orientação à queixa escolar (pp. 187-221). São Paulo, SP: Casa do Psicólogo.

Gollust, S. E., Thompson, R. E., Gooding, H. C., \& Biesecker, B. B. (2003). Living with achondroplasia in an average-sized world: An assessment of quality of life. American Journal of Medical Genetics Part A, 120(4), 447-458.

Gordon, M., Crouthamel, C., Post, E. M., \& Richman, R. A. (1982). Psychosocial aspects of constitutional short stature: Social competence, behavior problems, self-esteem, and family functioning. The Journal of Pediatrics, 101(3), 477-480. 
Guimarães, N. A. (2009). A sociologia dos mercados de trabalho, ontem e hoje. Novos estudos CEBRAP, 85, 151-170.

Hartmann, M., \& Honneth, A. (2009). "Paradojas del capitalismo". In A. Honneth (Ed.), Crítica del agravio moral. Patologías de la sociedad contemporánea. Buenos Aires, Argentina: Fondo de Cultura Económica.

He, L., Horton, W., \& Hristova, K. (2010). Physical basis behind achondroplasia, the most common form of human dwarfism. Journal of Biological Chemistry, 285(39), 3010330114.

He, L., Shobnam, N., Wimley, W. C., \& Hristova, K. (2011). FGFR3 heterodimerization in achondroplasia, the most common form of human dwarfism. Journal of Biological Chemistry, 286(15), 13272-13281.

Hill, V., Sahhar, M., Aitken, M. A., Savarirayan, R., \& Metcalfe, S. (2003). Experiences at the time of diagnosis of parents who have a child with a bone dysplasia resulting in short stature. American Journal of Medical Genetics, 122(2), 100-107.

Honneth, A. (2003). Luta por reconhecimento: a gramática moral dos conflitos sociais. São Paulo, SP: Editora 34.

Honneth, A. (2007). Reconhecimento ou redistribuição? A mudança de perspectivas na ordem moral da sociedade. In J. Souza \& P. Mattos (Orgs.), Teoria crítica no século XXI. São Paulo, SP: Annablume.

Honneth, A. (2008). Trabalho e reconhecimento: tentativa de uma redefinição. Civitas: Revista de Ciências Sociais, 8(1), 46-67.

Horton, W. A., Hall, J. G., \& Hecht, J. T. (2007). Achondroplasia. Lancet, 370(9582), 162172.

Howells, R., \& M. Chemers. (2005). Midget cities: Utopia, utopianism, and the vor-schein of the 'freak' show. Disability Studies Quarterly, 25(3), unpaged. Recuperado de http://dsqsds.org/article/view/579/756

Hughes, B. (1999). The constitution of impairment: Modernity and the aesthetic of oppression. Disability \& Society, 14(2), 155-172.

Jordão, A. P. F., \& Stampa, I. (2015). Precarização no "mundo do trabalho": a experiência dos ambulantes dos trens da Região Metropolitana do Rio de Janeiro. O Social em Questão, $34,315-338$.

Kennedy, D. (2003). Little people: Learning to see the world through my daughter's eyes. Emmaus, PA: Rodale.

Kirshbaum, H. (1991). Disability and humiliation. Journal of Primary Prevention, 12(2), 169181. 
Klein, D. C. (1991). Introduction to special issue. Journal of Primary Prevention, 12(2), 8791.

Klein, D. C. (1991). The humiliation dynamic: An overview. Journal of Primary Prevention, 12(2), 93-121.

Klein, D. C. (1992). Managing humiliation. Journal of Primary Prevention, 12(3), 255-268.

Klein, D. C. (2004, November). Appreciative Psychology: antidote to humiliation. In Annual Conference of Human Dignity and Humiliation Studies, United Nations-Mandated University for Peace, Costa Rica, $7^{\text {th }}$.

Klein, D. (2005, December). The humiliation dynamic: Looking to the past and future. In Annual Meeting of the Human Dignity and Humiliation Studies Network, Columbia Teachers College, New York City, NY.

Kruse, R. (2001). Activity spaces of dwarfs: Research via the Internet. The Geographic Bulletin, 43(1), 7-15. Recuperado de https://gammathetaupsilon.org/the-geographicalbulletin/2000s/volume43-1/article1.pdf

Kruse, R. (2002). Social spaces of little people: The experiences of the Jamisons. Social \& Cultural Geography, 3(2), 175-191.

Kruse, R. (2003). Narrating intersections of gender and dwarfism in everyday spaces. The Canadian Geographer/Le Géographe canadien, 47(4), 494-508.

Kuch, H. (2010). The rituality of humiliation: Exploring symbolic vulnerability. In P. Kaufmann, H. Kuch, C. Neuhauser, \& E. Webster (Eds.), Humiliation, degradation, dehumanization. Human: Dignity violated. (pp. 37-56). New York, NY: Springer. Recuperado de http://www.corteidh.or.cr/tablas/r30885.pdf

La Franiere, S. (2010, March). A miniature dwarf world magnifies dwarf life. The New York Times. Recuperado de https://www.nytimes.com/2010/03/04/world/asia/04dwarfs.html

Lazare, A. (1987). Shame and humiliation in the medical encounter. Archives of Internal Medicine, 147, 1653-1658.

Le Breton, D. (2007). A sociologia do corpo. (2a. ed.). Petrópolis, RJ: Vozes.

Lhuilier, D. (2014). Introdução à psicossociologia do trabalho. Cadernos de Psicologia Social do Trabalho, 17(spe), 5-20.

Lima, A. F. (2009). Sofrimento de indeterminação e reconhecimento perverso: um estudo da construção da personagem doente mental a partir do sintagma identidade-metamorfoseemancipação (Tese de Doutorado). Pontifícia Universidade Católica de São Paulo, São Paulo. Recuperado de https://tede2.pucsp.br/handle/handle/17369

Lima, M. P. (2012). Educação profissional de pessoas com deficiência: um estudo na cidade de São Paulo (Dissertação de mestrado). Universidade Federal de Lavras, Lavras, MG. 
LPA issues statement to abolish the "m" Word (2015, September). Recuperado de https://www.lpaonline.org/the-m-word.

Major, B., \& O'Brien, L. T. (2005). The social psychology of stigma. Annual Review of Psychology, 56, 393-421. Recuperado de https://wesfiles.wesleyan.edu/courses/PSYC309-clwilkins/week1/Major\%20\%26\%200\%27Brien\%202005.pdf

Manders, R. (2015). The social construction of dwarfism in British television comedy. Recuperado https://www.researchgate.net/publication/279961307_Social_Construction_of_Dwarfism _in_British_Television_Comedy

Mattos, P. C. (2006). A sociologia política do reconhecimento: as contribuições de Charles Taylor, Axel Honneth e Nancy Fraser. São Paulo, SP: Annablume.

Miller, P. S. (1987). Coming up short: Employment discrimination against little people. Harvard Civil Rights, Civil Liberties. Law Review, 22, 231-271.

Miller, W. I. (1993). Humiliation and shame: Comparing two affect states as indicators of narcissistic stress. Bulletin of the Menninger Clinic, 52, 40-51.

Money J. (1967). Dwarfism questions and answers in counseling. Rehabilitation Literature $28,134-138$.

Money, J., \& Pollitt, E. (1966). Studies in the psychology of dwarfism: II. Personality maturation and response to growth hormone treatmentin hypopituitary dwarfs. The Journal of Pediatrics, 68(3), 381-390.

Narayana, J., \& Horton, W. A. (2013). Molecular genetics of achondroplasia. eLS. Recuperado de https://doi.org/10.1002/9780470015902.a0024296

Neuhäuser, C. (2011). Humiliation: The collective dimension. In P. Kaufmann, H. Kuch, C. Neuhäuser, \& E. Webster (Eds.), Humiliation, degradation, dehumanization: Human dignity violated (pp. 21-36). New York, NY: Springer. Recuperado de http://www.corteidh.or.cr/tablas/r30885.pdf

Oliveira, S. R., \& Piccinini, V. C. (2011). Mercado de trabalho: múltiplos (des) entendimentos. Revista de Administração Pública, 45(5), 1517-1538.

Online Etymology Dictionary (2013). Etymology of the word Dwarf [online]. Recuperado de http://www.etymonline.com/index.php?term=dwarf

ONU mantém proibição francesa a "lançamento de anões" (2002, setembro 27). Reuters, Genebra. https://www1.folha.uol.com.br/folha/reuters/ult112u22081.shtml.

Orphanet (2017). Achondroplasia. Recuperado de http://www.orpha.net/consor/cgibin/OC_Exp.php?Lng=GB\&Expert=15 
Oviedo, R. A. M., \& Czeresnia, D. (2015). The concept of vulnerability and its biosocial nature. Interface-Comunicação, Saúde, Educação, 19(53), 237-250.

Popp, C. (2008). Liberdade negocial e dignidade da pessoa humana: aspectos relevantes. Revista Jurídica, 21(5), 45-72.

Relação Anual de Informações Sociais [RAIS] (2014). Características do emprego formal: principais resultados. Recuperado de http://portalfat.mte.gov.br/wpcontent/uploads/2016/02/Apresenta\%C3\%A7\%C3\%A3o-RAIS-2014divulga\%C3\%A7\%C3\%A3o.pdf

Ramírez, G. E. Á. (2010). Las situaciones de discriminación de las personas con acondroplasia en España. Informe Jurídico. Comité Español de representantes de personas con discapacidad. Madrid, Espanha: Grupo Editorial Cinca. Recuperado de http://www.fderechoydiscapacidad.es/wp-content/uploads/2016/12/Acondoplasia.pdf

Reeve, D. (2002) 'Negotiating psycho-emotional dimensions of disability andtheir influence on identity constructions', Disability \& Society, 17(5), 493-508.

Ribeiro, A. (1996). O corpo vai ao psicólogo. Cadernos de Consulta Psicológica, 12, 39-43.

Ribeiro, M. A., \& Carneiro, R. (2009). A inclusão indesejada: as empresas brasileiras face à lei de cotas para pessoas com deficiência no mercado de trabalho. Organizações \& Sociedade, 16(50), 545-564.

Ribeiro, M. A. (2011). Algumas contribuições brasileiras para a orientação profissional. In M. A. Ribeiro, \& L. L. Melo-Silva (Orgs.), Compêndio de orientação profissional e de carreira (v. 2, pp. 53-79). São Paulo, SP: Vetor.

Ribeiro, M. A. (2014). Carreiras: novo olhar socioconstrucionista para um mundo flexibilizado. Curitiba, PR: Juruá.

Ribeiro, M. A. R. (2017). Psicossocial: continuum ontológico do processo relacional. In N, S. Junior, \& W. Zangari (Org), A psicologia social e a questão do hífen (pp. 263-277). São Paulo, SP: Blucher.

Richette, P., Bardin, T., \& Stheneur, C. (2008). Achondroplasia: from genotype to phenotype. Joint Bone Spine, 75, 125-130.

Rieser, P. A. (1992). Educational, psychologic, and social aspects of short stature. Journal of Pediatric Health Care, 6(5), 325-332.

Sandberg, D. E., \& Voss, L. D. (2002). The psychosocial consequences of short stature: A review of the evidence. Best Practice \& Research Clinical Endocrinology \& Metabolism, 16(3), 449-463.

Sarlet, I. W. (2002). Dignidade da pessoa humana e direitos fundamentais na Constituição Federal de 1988. Porto Alegre, RS: Livraria do Advogado.

Schreiber, A. (2011). Direitos da Personalidade. São Paulo, SP: Atlas. 
Secretaria Internacional do Trabalho (2006). Gestão de questões relativas a deficiência no local de trabalho: repertório de recomendações práticas da OIT. Brasília, DF: Organização Internacional do Trabalho.

Shakespeare, T. (1994). Cultural representations of disabled people: Dustbins for disavowal. Disability \& Society, 9(3), 283-299.

Shakespeare, T. (1996). Disability, identity and difference. In C. Barnes, \& G. Mercer (Eds.), Exploring the divide (pp. 94-113). Leeds, England: The Disability Press. Recuperado de https://www.lemosandcrane.co.uk/bluesalmon_trial/resources/Exploring\%20the\%20Divi de\%20-\%20Disability,\%20Identity\%20and\%20Difference.pdf

Shakespeare, T. (2003, February 22). Ouch: Its a disability thing. Recuperado de http://www.bbc.co.uk/ouch/opinion/you_dont_get_dwarfs_on_the_radio_691.shtml

Shakespeare, T. (2006). Disability rights and wrongs. Abingdon, UK: Routledge.

Shakespeare, T., Thompson, S., \& M. Wright. (2007). A small matter of equality: Living with restricted growth. Newcastle: Newcastle University.

Shakespeare, T., Thompson, S., \& Wright, M. (2010.) No laughing matter: Medical and social experiences of restricted growth. Scandinavian Journal of Disability Research, 12(1), 1931.

Shakespeare, T., \& W. Watson. (1996). the body line controversy: A new direction for disability studies? In Hull Disability Studies Seminar. The exact date of the presentation is unknown. Recuperado de https://disability-studies.leeds.ac.uk/wpcontent/uploads/sites/40/library/Shakespeare-The-body-line-controversy.pdf

Shirley, E. D., \& Ain, M. C. (2009). Achondroplasia: Manifestations and treatment. Journal of the American Academy of Orthopaedic Surgeons, 17(4), 231-241.

Siegel, P. T., Clopper, R., \& Stabler, B. (1991). Psychological impact of significantly short stature. Acta Paediatrica Scandinavian, 377(suppl.), 14-18.

Stace, L., \& Danks, D. M. (1981). A social study of dwarfing conditions III. The social and emotional experiences of adults with bone dysplasias. Australian Paediatrics Journal, $17,177-182$.

Statman, D. (2000). Humiliation, dignity and self-respect. Philosophical Psychology, 13(4), 523-540.

Stephens, E. (2005). Twenty-first century freak show: Recent transformations in the exhibition of non-normative bodies. Disability Studies Quarterly, 25(3).

Thomson, R. G. (1996). From wonder to error: A genealogy of freak discourse in modernity. Freakery: Cultural spectacles of the extraordinary body, 1-19. 
Thompson, S., Shakespeare, T., \& M. Wright. (2008). Medical and social aspects of the life course for adults with a skeletal dysplasia: A review of current knowledge. Disability and Rehabilitation, 30(1), 1-12.

Tomé, R. J. M. (2014). Deficiência, nanismo e mercado de trabalho: dinâmicas de inclusão e exclusão (Dissertação de Mestrado). Instituto Universitário de Lisboa, Lisboa, Portugal. Recuperado de https://repositorio.iscteiul.pt/bitstream/10071/8465/3/FINAL_2014_revista.pdf

Triviños, A. N. S. (2015). Introdução à pesquisa em ciências sociais: a pesquisa qualitativa em educação. São Paulo, SP: Atlas.

Toldrá, R. C., De Marque, C. B., \& Brunello, M. I. B. (2010). Desafios para a inclusão no mercado de trabalho de pessoas com deficiência intelectual: experiências em construção. Revista de Terapia Ocupacional da Universidade de São Paulo, 21(2), 158-165.

Unger. S., Bonafé. L., \& Gouze, E. (2017). Current care and investigational therapies in achondroplasia. Current Osteoporosis Reports, 15(2), 53-60.

Warkany, J. (1973). Dwarfs and other little people: An overview. Seminars in Roentgenology, $8(2), 135-138$.

World Health Organization/The World Bank (2012). Relatório mundial sobre a deficiência. São Paulo, SP: SEDPcD. Recuperado de https://apps.who.int/iris/bitstream/handle/10665/44575/9788564047020_por.pdf;jsessioni $\mathrm{d}=8649753 \mathrm{CF} 5 \mathrm{BC}$ 899EF16E18507367D89A? sequence $=4$ 


\section{Anexo}




\section{Anexo 1: Termo de consentimento Livre e Esclarecido}

\section{TERMO DE CONSENTIMENTO LIVRE E ESCLARECIDO}

Você está sendo convidado(a) a participar, como voluntário(a), desta pesquisa. Caso concorde em participar, favor assinar ao final do documento. Sua participação não é obrigatória e, a qualquer momento, poderá desistir e retirar seu consentimento. Sua recusa não trará nenhum prejuízo à sua relação com o pesquisador (a) ou com a instituição. Você receberá uma cópia deste termo onde consta o telefone e endereço do pesquisador(a) principal, podendo tirar dúvidas do projeto e de sua participação.

\section{INFORMAÇÕES SOBRE A PESQUISA:}

Título do Projeto: O trabalho de pessoas com nanismo: tensões psicossociais para a sua inclusão no mercado de trabalho

Pesquisador Responsável: Marcelo Ribeiro

Telefone para contato: (11) 3091-1968

Pesquisador executor: Michelle Pinto de Lima

Será realizada uma entrevista cujo objetivo é compreender como o estigma do nanismo e suas consequências vivenciadas no meio social se reproduzem na esfera do trabalho.

A entrevista deve durar aproximadamente 90 minutos, dependendo da sua disponibilidade, e será gravada. A gravação da mesma ficará armazenada no Centro de Psicologia Aplicada ao Trabalho - CPAT - do Instituto de Psicologia da Universidade de São Paulo com acesso restrito e sem identificação dos entrevistados.

Vale salientar que a participação é voluntária e a entrevista pode ser interrompida a qualquer momento. Além disso, o sigilo está garantido e sua identidade não será revelada sob nenhuma hipótese. 
O material coletado na pesquisa poderá ser utilizado em uma futura publicação em livro e/ou periódico científico, mas, novamente, reforça-se o sigilo, pois em nenhum momento sua identidade será revelada. Você poderá solicitar quaisquer esclarecimentos sobre a pesquisa nos telefones acima indicados, durante a entrevista, ou através do Comitê de Ética em Pesquisa com Seres Humanos do IPUSP: Av. Prof. Mello Moraes, 1721, Bloco F, sala 22 - Cidade Universitária - São Paulo/SP. Telefone: (11) 3097-0529.

A pesquisa não trará nenhum risco a você e nem oferecerá alguma vantagem financeira.

\author{
Pesquisador Responsável: Prof. Dr. Marcelo Afonso Ribeiro \\ Instituto de Psicologia da USP \\ Departamento de Psicologia Social e do Trabalho - PST
}

Michelle Pinto de Lima - Pesquisadora Executora

Aluna regular de Pós- Graduação

Instituto de Psicologia da USP - PST

\title{
CONSENTIMENTO DA PARTICIPAÇÃO DA PESSOA COMO SUJEITO
}

$\mathrm{Eu}$, , abaixo assinado, concordo em participar do estudo "O trabalho de pessoas com nanismo: tensões psicossociais para a sua inclusão no mercado de trabalho" como sujeito. Fui devidamente informado e esclarecido pela pesquisadora Michelle Pinto de Lima sobre a pesquisa, os procedimentos nela envolvidos, assim como os possíveis riscos e benefícios decorrentes de minha participação.

Local e data:

Nome e Assinatura do participante: 